
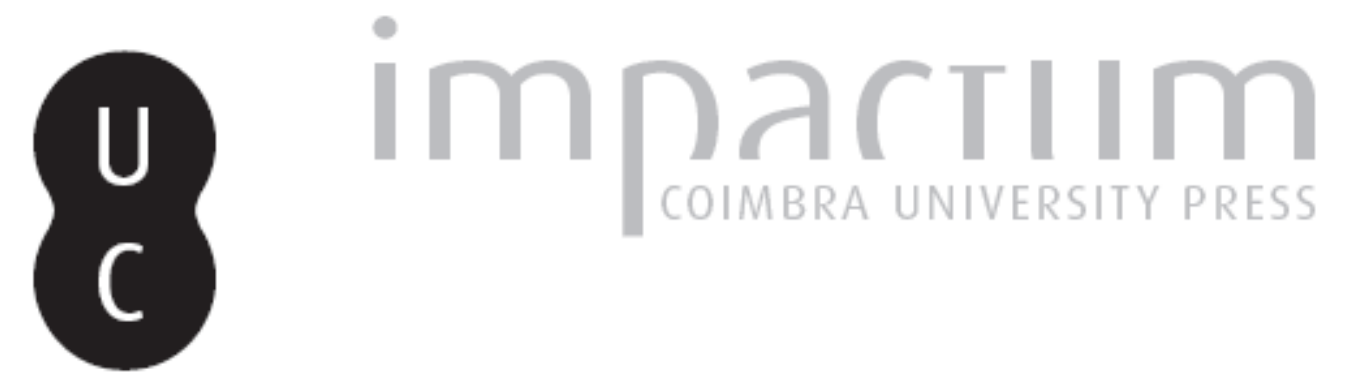

\title{
Da juventude de António Sérgio: algumas cartas inéditas
}

Autor(es): $\quad$ Franco, Matilde Figueiredo de Sousa

Publicado por: Imprensa da Universidade de Coimbra

URL persistente:

URI:http://hdl.handle.net/10316.2/45059

DOI:

DOI:https://doi.org/10.14195/2183-8925_5-2_3

Accessed : $\quad$ 26-Apr-2023 06:06:38

A navegação consulta e descarregamento dos títulos inseridos nas Bibliotecas Digitais UC Digitalis, UC Pombalina e UC Impactum, pressupõem a aceitação plena e sem reservas dos Termos e Condições de Uso destas Bibliotecas Digitais, disponíveis em https://digitalis.uc.pt/pt-pt/termos.

Conforme exposto nos referidos Termos e Condições de Uso, o descarregamento de títulos de acesso restrito requer uma licença válida de autorização devendo o utilizador aceder ao(s) documento(s) a partir de um endereço de IP da instituição detentora da supramencionada licença.

Ao utilizador é apenas permitido o descarregamento para uso pessoal, pelo que o emprego do(s) título(s) descarregado(s) para outro fim, designadamente comercial, carece de autorização do respetivo autor ou editor da obra.

Na medida em que todas as obras da UC Digitalis se encontram protegidas pelo Código do Direito de Autor e Direitos Conexos e demais legislação aplicável, toda a cópia, parcial ou total, deste documento, nos casos em que é legalmente admitida, deverá conter ou fazer-se acompanhar por este aviso.

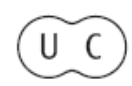




\section{REVISTA DE HISTÓRIA DAS IDEIAS 5}

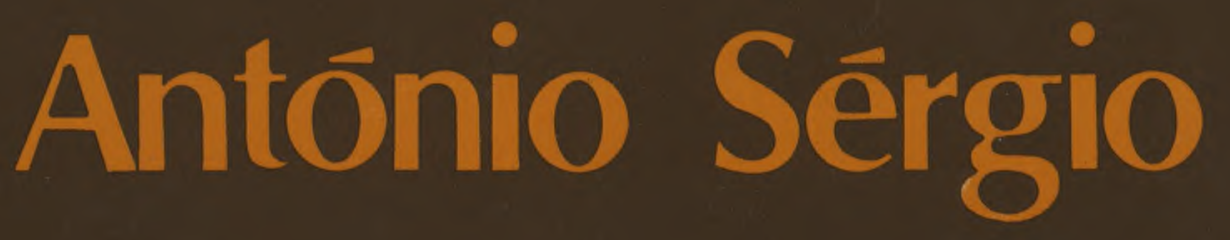

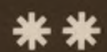

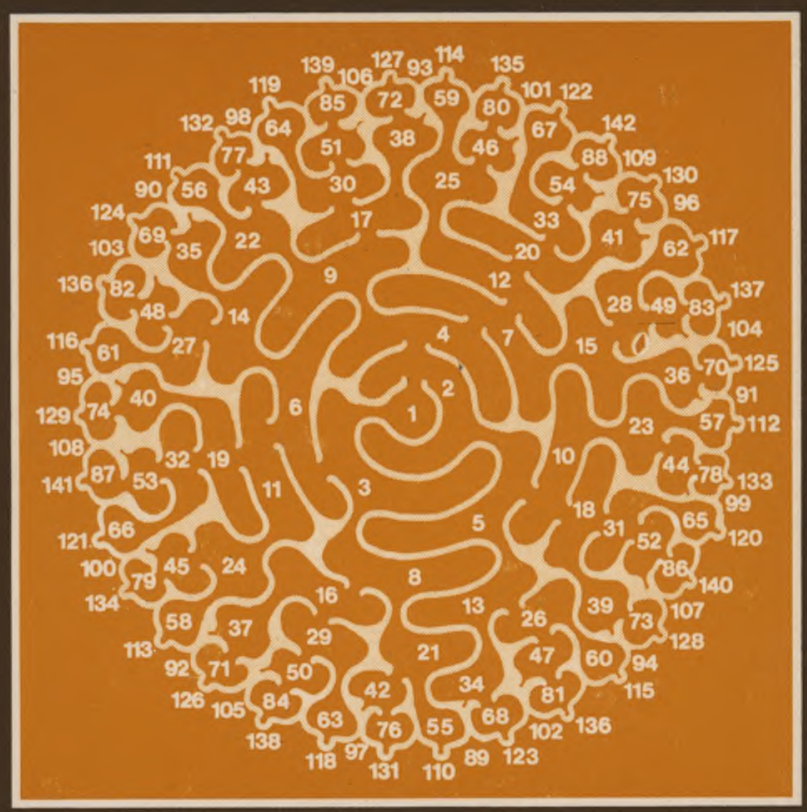

INSTITUTO DE HISTÓRIA E TEORIA DAS IDEIAS FACULDADE DE LETRAS

COIMBRA 1983 


\title{
DA JUVENTUDE DE ANTÓNIO SÉRGIO
}

\author{
Algumas cartas inéditas
}

\section{APRESENTAÇÃO}

Os cerca de cem documentos originais da juventude de António Sérgio, que estavam na sua quase totalidade inéditos $C$ ) e agora se apresentam ao público, terão, pelo menos, um triplice interesse. Eles são, desde logo, um testemunho, com uma qualidade literária e intelectual rara em documentos espontâneos, dos pensadores que então mais interessavam António Sérgio, das leituras em que mais se comprazia, dos problemas com que se preocupava - e confirmam amplamente a tese, que tenho defendido, da importância do espiritualismo sergiano, enriquecendo, assim, a imagem comum de um Sérgio rigidamente racionalista. Em segundo lugar, creio que estes textos ajudam a conhecer melhor o «jovem Sérgio», então entre os 19 e os 26 anos, dotado de inteligência pujante e já de uma invulgar maturidade, em época crucial da sua opção de vida, nos dominios intelectual, profissional, sentimental também... Em terceiro lugar, estas cartas mostram o itinerário primeiro da longa história de amor de António e Luisa Sérgio, esposa dedicadíssima e colaboradora de mérito ao longo de quase cinquenta anos: nelas palpita um romance de amor vivo, que iria continuar por toda a vida de ambos. Romance que, como todo o verdadeiro "romance», é romântico, sem deixar de ser reflectido, reflexivo e lúcido.

Trata-se, então, do que vulgarmente se poderia chamar umas «cartas de namoro». Se fossem apenas isso, não teriam elas porventura suficiente interesse cultural, nem haveria talvez o direito moral de as

C) Transcrevi alguns extractos desta colecção de cartas (que ainda agora não foi possível publicar integralmente, faltando ainda diversas cartas, sobretudo de Luisa Sérgio) em dois meus trabalhos anteriores: "António Sérgio - Cartas inéditas da juventude», in $J L$ - Jornal de Letras, Artes e Ideias, n. 57, 26 de Abril de 1983; «O espiritualismo de António Sérgio e a necessidade de investigação da obra sergiana», comunicação em 2 de Outubro de 1983, na Fundação Calouste Gulbenkian, por ocasião da inauguração das comemorações nacionais do $10^{\circ}$ Centenário do Nascimento de António Sérgio. Foi ainda feita transcrição de uma carta, embora sem indicação de proveniência, pelo Prof. Vasco Magalhães-Vilhena: «Em torno da génese do idealismo filosófico de António Sérgio», in Academia das Ciências de Lisboa, Instituto de Altos Estudos - Homenagem a Antônio Sérgio, Lisboa, 1976, pp. 136-137. 
revelar. Mas estas cartas ultrapassam, parece-me, o mero interesse biográfico, e chegam, pelo seu conteúdo, cheio de beleza formal e espiritual, a assumir valor não pequeno para a cultura portuguesa.

A leitura destas cartas convenceu-me de que elas podem dar azo a numerosos e interessantes estudos sobre a vida de António Sérgio e a génese do seu pensamento. Nelas se reflectem, com a clareza que costuma marcar por vezes os escritos de juventude, as suas leituras dominantes - tanto no campo das preferências literárias como no da reflexão estética $\left({ }^{2}\right)-$, os problemas existenciais que mais marcaram esta fase da vida de António Sérgio, o seu ambiente familiar e os amigos que tinha ao tempo. De nada disso me proponho agora tratar em profundidade, pois acho que antes do mais interessa divulgar estes documentos e facilitar a sua leitura.

Com tal intenção, nesta despretenciosa introdução darei apenas alguns esclarecimentos relativamente às - referências feitas nestas cartas a alguns locais, pessoas de família, amigos e conhecidos, que foi possível identificar. Penso que se trata de elementos imprescindíveis para o cabal entendimento das cartas. Mas eles poderão ainda ser úteis para elucidar a biografia de António Sérgio que, por vezes, mesmo em autores de responsabilidade, enferma de erros ou inexactidoes sobre dados ou elementos de mais difícil acesso a quem não tem G privilégio, como a autora destas linhas, de ser familiar do grande pensador.

Antes do mais, cumpre situar as cartas que ora se publicam; depois, tentar-se-á ajudar o leitor mais atento com algumas indicações que, apesar da sua aridez, permitirão entender melhor múltiplas referências feitas nas cartas, além de fornecerem dados inéditos sobre a família de António Sérgio.

\section{ENQUADRAMENTO DAS CARTAS: O TEMPO E OS LOCAIS}

A primeira carta data de Outubro de 1902. António Sérgio tinha feito 19 anos em 3 de Setembro anterior e era aluno da Escola Naval, pois tinha escolhido, a exemplo do avô $\left({ }^{3}\right)$ e do pai $\left({ }^{4}\right)$, a carreira da Marinha.

O Será interessante atentar na seguinte lista, por ordem alfabética do último (ou principal) nome, dos autores referidos, citados ou comentados nestas cartas:

Mariana Alcoforado, Moniz Barreto, João de Barros, Boileau, Paul Bourget, F. Brunetière, Camilo, Camões, Carlyle, Castilho, Santa Catarina de Siena, Cervantes, M. Pinheiro Chagas, Chateaubriand, Júlio Dantas, René Doumic, Epicteto, Ésquilo, Evangelho (segundo S. Mateus), Flaubert, Fromentin, Garrett, Goethe, Delfim Guimarães, Georges Guyau, Homero, Horácio, Ibsen, La Bruyère, La Fontaine, Lamartine, Monsenhor Landriot, Leconte de Lisle, Maeterlinck, Marco Aurélio, Oliveira Martins, Lopes de Mendonça, C. Michaël is, Michelet, Molière, Montaigut, Musset, Gaston Paris, Marco Pilo, P'atâo, Charles de Pomairols, Antero de Quental, Racine, Salomon Reinach, Renan, Silvio Romero, Ronsard, Rousseau, Sainte-Beuve, George Sand, Shakespeare, Shelley, Souriau, Sully-Prudhomme, Taine, Augustin Thierry, Victor Hugo, Vigny, H. Vilhena c Voltaire.

(?) O avô foi o Visconde Almirante Antônio Sérgio de -Sousa (1809-1878)* o qual, partidário do regime liberal, foi forçado a emigrar para Inglaterra em Junho de 1831 e, segundo a revista $O$ occidente de 1 de Junho de 1878, «foi um dos officiaes da armada que mais dedicadamente batalhou pelas instituições liberaes». Tomou, assim, parte nas aç̧ões desenvolvidas na Ilha Terceira, nõ Mindelo e no'cerco do Portó, no Combate naval do Cabo de S. Vicente, tendo a sua intervenção sido muito elogiada pelo Almirante Napier. Logo após as vitórias dos liberais, exerceu importantes comissões, entre as quais as de governa- 
Anote-se que estas cartas são contemporâneas dos primeiros livros que António Sérgio publica. Nelas se lhes faz referência e transcrevem-se mesmo extractos. Rimas, publicado em 1908, constituído por quarenta e duas poesias agrupadas em três núcleos: "Os Navegadores», «A Natureza e a Idéa» e "Via Dolorosa»; e Notas sobre os Sonetos e as Tendências Gerais da Filosofia de Antero de Quental, redigido entre 1903 e 1908 e publicado em 1909. Ambos estes livros foram impressos na Tipografia do Anuário Comercial, da qual era então proprietário Manuel José da Silva, pai da então sua namorada e depois sua mulher, Luisa Estefânia da Silva.

Concluído o curso da Escola Naval em 1904, é nomeado guarda-marinha e vai para Macau, onde permanece, em 1905, durante quase o ano todo. Em 1906 efectúa uma viagem rápida a New-Castle e, ainda nesse ano, tem uma permanência, que dura até Maio de 1907, em Cabo Verde. Em Março de 1907 é promovido a segundo-tenente e em Julho de 1907 está já colocado na metrópole, no Corpo de Marinheiros da Armada e não torna a realizar viagens de serviço (5). Na entrevista que António Sérgio deu a Igrejas Caeiro, em Julho de 1958, ele próprio refere que, como oficial de marinha, foi a Moçambique, índia Inglesa, Macau, Filipinas, Zâmbia, Cabo Verde.

Nas cartas que agora se publicam, vê-se, por exemplo, que em 4 de Setembro de 1905 Sérgio se encontra em Macau, em inicios de Julho do ano seguinte escreve de uma quinta da família, perto de Torres Novas, onde também está, por exemplo, em meados de Agosto de 1908 e em numerosas outras ocasiões.

dor de Moçamedes e Angola (de 1849 a 1854), a de governador da província de Macau e Timor (de 1868 a 1872) e a de Governador-Geral da índia, de 1877 à data da sua morte. Alguma bibliografia: Grande Enciclopédia Portuguesa e Brasileira, vol. 28, p. 412; Augusto Carlos Xavier $o$ Visconde de Sergio de Sousa, Lisboa, 1878; Mendonça Torres $O$ Distrito de Mossamedes, Lisboa, 1950; A. Felner Angola, vol. I, Lisboa, 1940; José F. Ferreira Martins os Vice-Reis da india, 1505-1917, Lisboa, 1935; Tratado de todos os Vice-Reis $e$ Governadores da india, Lisboa, 1962; Nobreza de Portugal, Editorial Enciclopédia, vol. III, Lisboa, 1961, pp. 371-373; Albana da Silva Pinto, Visconde de Sanches de Baena Resen ha das Familias Titulares e Grandes de Portugal, vol. II, Lisboa [1890], p. 607.

$\left(^{4}\right)$ O pai foi um «homem excepcional», segundo a própria expressão de António Sérgio na entrevista radiofónica concedida a Igrejas Caeiro. Foi filho terceiro de António Sérgio de Sousa e segundo filho varão, chamou-se também António Sérgio de Sousa, nasceu em 1842, faleceu, em Lisboa, em 1906, tendo, como o pai, atingido o posto de vice-almirante. Seguiu a mesma carreira do progenitor, enquanto o seu irmão mais velho, José Zeferino, enveredou para o exército, onde atingiu o posto de general de brigada. António Sérgio de Sousa foi ajudante do Governador de Ango'a (1868) e do de Macau (1869). Quando esteve em Luanda, em 1873, era então $1 .^{\circ}$ tenente, dirigiu o mensário «O Meteoro», dedicado aos problemas económicos e administrativos de Angola. Em 1878 governou o distrito de Dm e foi governador do distrito de Damão, até finais de 1883 , estando no desempenho destas funções, em Damão, quando aí nasceu, em 3 de Setembro de 1883, o único filho varão, o terceiro António Sérgio de Sousa. Em 1890 foi nomeado governador do recém-criado distrito do Congo, o qual incrementou muito, e regressou à metrópole em 1894. Aqui, foi chefe da 1.a Repartição do Conselho do Almirantado, depois secretário e faleceu como comandante do Corpo de Marinheiros. Foi do Conselho de Sua Majestade e, como o pai, teve numerosas condecorações. Alguma bibliografia: «Grande Enciclopédia Portuguesa e Brasileira», vol. 28, p. 412; «Nobreza de Portugal», Editorial Enciclopédia, vol. III, Lisboa, 1961, p. 373; Júlio de Castro Lopo, «Jornalismo em Angola»; Lopes Rodrgiues, artigo cit. na nota 24.

$\left(^{5}\right)$ Mário Sottomayor Cardia «O pensamento filosófico do jovem Sérgio», in Cultura-História e Filosofia, vol. I, Lisboa, 1982, pp. 411-467. 
$A$ correspondência que se refere consiste na quase totalidade em cartas, mas também bilhetes-postais e mesmo cartões de visita, conforme se anota em cada caso.

Qual foi o universo físico que viu estas missivas de António Sérgio serem escritas? Muitas não têm indicação da data nem de local, mas dos elementos de que disponho posso dizer que quase todas são redigidas em Lisboa, vários escritos o são da Quinta dos Vargos e há a referida carta de Macau.

António Sérgio vivia, então, em Lisboa, na Rua Maria Andrade, $n .^{\circ} 55,4 .^{\circ}$ andar e a noiva, também em Lisboa, na Rua António Maria Cardoso, n.os 22/24. A Quinta dos Vargos, que serve de cenário a muitos dos escritos e dos acontecimentos referidos era então propriedade da tia de António Sérgio, Maria do Pilar Sérgio de Sousa Paes. No Inventário Artístico de Portugal. Distrito de Santarém, refere-se, no concelho de Torres Novas, o Solar dos Vargos como «grande residência rural do século XVIII, com entrada nobre e escadaria de bela traça...» $\left({ }^{6}\right)$. A capela do solar tem a data de 1726 e é revestida de azulejos; a casa, hoje bastante deteriorada, mas conservando restos da antiga grandeza, costumava ser (como, aliás, se depreende das cartas) animado local de convívio, da numerosa família e amigos, entre os quais se contavam Luisa Estefânia Gerschey da Silva, futura mulher de António Sérgio e a quem se dirigem estas cartas.

A tia Pilar faleceu em 1910, sem geração, e a casa dos Vargos ficou para a sua irmã mais nova, madrinha de António Sérgio, Matilde Sérgio de Sousa Quintanilha, que faleceu em 1927. Os Vargos foram herdados pela filha mais nova, também Matilde e, depois, pela filha desta, outra Matilde, a actual proprietária.

Se me detenho um pouco a referir os Vargos, é porque ali, naquele ambiente campestre e romântico, onde o próprio António Sérgio revela que desenhava as árvores (carta de 29 de Maio de 1909), é que foi o local onde começou, desde 1901 ou 1902, a estimar Luisa Silva, como ele mesmo escreve (carta de 9 de Junho de 1909).

\section{?. PESSOAS REFERIDAS NAS CARTAS}

\subsection{Luisa Estefânia Gerschey da Silva, seu pai e irmão}

$A$ destinatária destas cartas e de várias poesias de António Sérgio, agora também divulgadas, era, como atrás disse, Luisa Estefânia Gerschey da Silva.

Luisa Estefânia nasceu, em Lisboa, a 4 de Setembro de 1879 e faleceu, na mesma cidade, na sua casa da Travessa do Moinho de Vento, n. ${ }^{\circ}$, à Estrela, freguesia da Lapa, em 29 de Fevereiro de 1960. Era filha de Manuel José da Silva, grande comerciante, de ascendência nobre, que nasceu em Lisboa em 4 de Agosto de 1854 e faleceu no Rio de Janeiro, onde viveu vários anos, a 16 de Julho de 1932, e de sua mulher Estefânia Gerschey, que, em Lisboa, nasceu, casou e, a 19 de Junho de 1882, faleceu. Estefânia Gerschey era filha de Francisco Augusto Gerschey, de nacionalidade húngara, que veio para a Simão Paes de Faria Pereira do Amaral e Menezes, marido da tia Pilar e padrinho de António Sérgio; este foi baptizado, em perigo de vida, em Damão e, solenemente, em Lisboa, na Igreja de Santos-o-Velho, em 1885. 
Portugal em 1836, com a comitiva de D. Fernando II, e irmã do distinto violinista Augusto Ladislau Gerschey, que faleceu em Lisboa em 1915.

Manuel José da Silva e Estefânia Gerschey tiveram ainda outro filho, João Cristiano Gerschey da Silva $\left({ }^{T}\right)$, nascido em Junho de 1881 e referido nas cartas apenas com o nome de João.

Luisa e João ficaram, portanto, órfãos de mãe em tenra idade* mas o pai deu-lhes esmerada educação.

Luisa Estefânia foi uma mulher notável: inteligente, culta, extremamente bondosa, sensata. Católica fervorosa, era membro activo da Conferência de S. Vicente de Paulo e será interessante referir que o marido, embora agnóstico, a acompanhava frequentemente nas suas manifestações de fé. Revelou-se artista de variadas facetas: pianista e cantora de mérito (e como tal referida na documentação que agora se publica), era também dotada pintora. Pintou, a óleo sobre tela, flores e retratos, com influência de Columbano e Malhoa. Também pintou louça, sobre porcelanas da Vista Alegre e estrangeiras, no estilo das antigas decorações de Saxe e de Sèvres e, como tal, aparece citada na fundamental obra Cerâmica Portuguesa de José Queirós* cuja primeira edição data de 1907. Luisa Estefânia era poliglota e mesmo tradutora. Em 1902, publicou, com o pseudónimo de Lakmé d'Avlis, o romance Um Momento no Paraíso, imitação do alemão, mencionado nas cartas.

Nestas missivas, António Sérgio mostra já bem a sua grande preocupação com os problemas de educação, começando por «educar» a noiva.

Talvez por influência do marido (com quem se casou em 14 de Junho de 1910), Luisa Sérgio publicou, em 1915, O Método Montessori, com prefácio e notas de Sérgio, a primeira obra que em Portugal mostrou a orientação pedagógica de Maria Montessori. Com o marido colaborou numa série de histórias infantis e, também com ele, publicou, em 1919, Contribuição para o estabelecimento de uma escala de pon-r tos dos níveis mentais das crianças portuguesas.

\subsection{A mãe e as irmãs de António Sérgio $\left({ }^{8}\right)$}

A mãe de António Sérgio chamava-se Ana Maria Salema Henriques de Brito Sérgio de Sousa. Nasceu, em Pondá, em 1855 e faleceu, em Lisboa, em 1948. Era filha do governador da Praça de Aguada, General José Inácio de Brito, e de Juliana Luisa Salema Henriques (9). Descendia do General Almirante Henrique Carlos Henriques, o qual,

${ }^{(7)}$ Casou civilmente, em Nova Iorque, a 16 de Julho de 1915> com Gabriel le Guittard, que nasceu em S. Francisco (Estados Unidos da América) em 1883 e a qual faleceu em Londres, em 1964.

${ }^{8}$ António Sérgio, o escritor, terceiro António Sérgio de Sousa, o qual assina algumas destas cartas como António Sérgio dé Sousa Júnior.

${ }^{9}$ ) Tiveram mais dez filhos (Ana foi a que nasceu em $1 .^{\circ}$ lugar): Constantino José de Brito, General de Engenharia, casou com Maria José B. Lapa; Luís José de Brito, Tenente da Guarnição da índia, casou com Josefa C. Caiado; Adelaide Amá1iâ, casou com Constancio dos Santos; Hedwiges Hipólita, casou, pela 1.a vez, com o tabelião Frederico de Oliveira Pegado e, pela 2.a vez, com o Coronel Augusto Correia Mendes; Adriano Heitor de Brito; Eugênio Albino de Brito, casóu com Maria do Carmo Martins; Joaquim Carlos de Brito, casou com Valentina Lemos; Frederico Aníbal de Brito, casou com Sofia de Campos; Maria Adelina, casou com João Carlos A. Diniz d'Ayalla; Francisco Xavier de Brito, coronel na índia, que casou com Leonor Luisa Carnero de Sousa e Faro. 
nascido na metrópole, se distinguiu, na índia, no século XVIII. Casou, talvez em 1879, com António Sérgio de Sousa, o segundo deste nome.

Consta, na família, que era das senhoras mais bonitas que frequentavam o paço real (será exagero?) e que terá tido grande desgosto por o filho, António Sérgio, não ter querido ser apresentado à família real.

O pai de António Sérgio, por quem este nutria grande admiração e estima, já foi atrás detalhadamente referido ${ }^{(10)}$. Faleceu em 1906, quando os documentos agora publicados são ainda esparsos. Este segundo António Sérgio de Sousa teve cinco filhos, quatro raparigas e um único rapaz, o escritor António Sérgio, nascido em $4 .^{\circ}$ lugar.

António Sérgio refere-se, numerosas vezes, nas cartas, às irmãs:

- Maria - Maria da Conceição Sérgio de Sousa Torres Vaz Freire, que faleceu em 1949. Casou com João Barreiros de Torres Vaz Freire, de quem teve dois filhos (José Sebastião e Jacinto) e enviuvou em 1900. Vivia em Évora, tendo tornado a casa onde residia - o solar que pertencera ao Bispo D. João da Silveira - num verdadeiro centro cultural, como o provam as notícias publicadas na imprensa da época.

- Pilar - Maria do Pilar Sérgio de Sousa, a qual casou, em 1926, com o Mestre Escultor João da Silva ("). Foi pianista de mérito, discipula de Mestre Viana da Mota, com o qual chegou a tocar, em concertos com dois pianos. Tirou o curso de piano no Conservatório, em Lisboa. Esteve alguns anos na Suiça, onde foi professora. Faleceu, sem ter tido filhos, em Outubro de 1960, apenas meses depois da morte do marido.

- Matilde (que aparece nas cartas também designada pelo seu diminutivo de «Tuca») - Nasceu, como o irmão, em Damão e casou, em 1907, com António Alemão de Mendonça Cisneiros de Faria. António Cisneiros de Faria (conhecido, familiarmente, por Mene e, como tal, designado nestas cartas), foi distinto oficial de Marinha, funções nas quais apoiou a viagem aérea de Gago Coutinho e Sacadura Cabral, ao Brasil, e comandou o navio escola "Sagres» $\left({ }^{12}\right)$. Tendo enviuvado em 1946, Matilde Sérgio de Sousa Cisneiros de Faria faleceu em 1961, sem geração.

- Juliana - A irmã mais nova nasceu em 5 de Julho de 1885, também na índia, como os dois irmãos anteriores a si, mas em Bandorá (Bombaim). Casou, em 1908, com o oficial de Cavalaria Eduardo Augusto de Oliveira Pessoa, o qual é referido nestas cartas, por vezes, como «Cavalarias», segundo o usual gosto de António Sérgio em arranjar nomes aos seus familiares e amigos. Teve quatro filhos: José, que nasceu a 15 de Setembro de 1909 (e cujo nascimento é referido nestas cartas), Maria Adelaide, Carlota Matilde e António. Juliana Ana Henriques de Brito Sérgio de Sousa Oliveira Pessoa faleceu com 49 anos. $O$ marido, que faleceu em 1956, atingiu o posto de coro-

í10) Vd. a nota 4.

C'1) Sobre João da Silva, consultem-se, por exemplo, Grande Enciclopédia Portuguesa e Brasileira, vol. 28, p. 81; Prof. Escultor António Duarte «Homenagem ao Escultor João da Silva, no centenário do seu nascimento, pela Academia Nacional de Belas-Artes», in Belas-Artes, Revista e Boletim da Academia Nacional de Belas-Artes, 3. ${ }^{\mathrm{a}}$ série, $\mathbf{n} .^{\circ} \quad 2$, Lisboa 1980, pp. 29-35; Dr. Fernando Castelo-Branco «No $1 .^{\circ}$ Centenário do Nascimento de João da Silva-quase uma polémica sobre a estátua equestre de D. João IV», ibidem, pp. 53-57; Medalhas de João da Silva, catálogo elaborado por Mário Correia de Sousa, Artur Santa Bárbara, Edição «Gravarte», Lisboa, 1983.

$<1 \mathrm{~J})$ Veja-se, por exemplo, Grande Enciclopédia Portuguesa e Brasileira, vol. 6, p 877. 
nel, tendo o seu nome sido dado a uma rua de Cascais, como benemérito que foi da vila e como aconteceu com outros membros da familia Pessoa.

\subsection{Outros familiares}

Várias outras pessoas da familia são ainda referidas nestas cartas, como as seguintes, que se indicam, também para ajudar a um melhor entendimento do seu texto:

- Tia Pilar - Designada, em família, como tia Pilar dos Vargos, para melhor se distinguir de homónimas, era a então proprietária da Quinta dos Vargos, a referida Maria do Pilar Sérgio de Sousa Paes, filha segunda do primeiro António Sérgio de Sousa, nascida em 1841, desde 1890 viúva de Simão Paes de Faria do Amaral e Menezes, senhor das Casas dos Vargos, do Caneiro $\left({ }^{13}\right)$ e outros vínculos.

- Tios José e Carlota - Trata-se do General José Zeferino Sérgio de Sousa (14), filho primogénito do primeiro António Sérgio de Sousa, o qual nasceu em 1836 e casou com Carlota Ferreira Maia, parece que em 1867, tendo morrido em 1929. Não tiveram filhos.

Tia Matilde - Matilde Sérgio de Sousa Quintanilha, nascida em $18 \overline{46}$, quarta filha do primeiro António Sérgio de Sousa (15), casada com o General Raimundo José Quintanilha, teve três filhos: Júlia, Raimundo e Matilde, os quais são também mencionados nas cartas. Júlia, casou-se com Pedro Pais de Faria Caupers e foi dona da referida Quinta do Caneiro. Matilde, casou-se com Gabriel Vítor Bugalho Pinho e herdou, como acima dissemos, a Quinta dos Vargos. Em relação com estas cartas, destes três primos de António Sérgio deve-se salientar Raimundo, que foi director da contabilidade do Ministério da Marinha e casou, em 1911, com Ruth de Freitas Noronha Waddington, a qual é, muitas vezes, referida nas cartas. Ruth morreu cedo, de parto, e sobre ela escreveu a advogada e poetisa Maria Cândida Parreira, no jornal O Dia, por ocasião da sua morte, em Junho(?) de 1914, um artigo, de que se transcrevem uns pedaços: ... «Pobre Ruth! Pobre amiga!... de uma intelligencia superior e d'uma não vulgar cultura intellectual, seu espírito prendia d'uma forma extraordinaria... Mas onde Ella se impunha sobretudo, era na formosura da sua alma! Não conheci ainda carácter mais nobre e mais elevado!»...

- Tia Maria José - Tia materna de António Sérgio, casada com o General Constantino José de Brito (16) e filha dos Viscondes de Vila Nova de Ourém.

- Tia Helena - Tia paterna de Luisa Estefânia da Silva e irmã mais velha de seu pai. Nasceu em 1850 e morreu em 1935, no estado de solteira.

- Silva Teles, ou Primo Teles - Primo de António Sérgio, creio que pelo lado de sua mãe (17). Trata-se de Francisco Xavier da Silva Teles, que nasceu em Pondá, índia, em 1860, e morreu, em Lisboa, em 1930. Segundo o Professor Ilídio do Amaral foi: «...o primeiro

(i3) Vd. mencionado volume do Inventário Artístico de Portugal, p. 153, referência à Casa da Quinta do Caneiro, próximo de Vila Nova de Ourém.

<") Vd. nota 4.

$\left.C^{15}\right)$ O primeiro António Sérgio de Sousa teve cinco filhos: José Zeferino, Maria do Pilar, António, Matilde e Luís Maria, o mais novo e que morreu ainda jovem e solteiro. C«) Vd. nota 9.

$\left.0^{T}\right)$ Note-se que um irmão da avó materna de António Sérgio era Francisco Xavier Salema Henriques, que nasceu e morreu em Pondá e casou com Leopoldina da Silva Teles. 
professor universitário de Geografia no nosso pais. Com ele abrir-se-ia um campo novo: o da geografia científica, que defendeu repetidas vezes...» (18). Sérgio, em 1913, dedica a este seu primo o estudo $D a$ Natureza da Affecção, publicado no Rio de Janeiro.

- Roberto - Roberto Henriques de Brito Oliveira Pegado, primo direito de António Sérgio, pelo lado materno, filho de Hedwiges $\left({ }^{19}\right)$.

- Prima Adelina - Adelina Salter de Sousa f ${ }^{20}$ ).

\subsection{Outras pessoas mencionadas}

Entre as pessoas mencionadas nas cartas e que não pertencem à família de António ou de Luisa Sérgio, são de destacar:

- Almirante Capelo - $\mathbf{E}$ o célebre explorador africano Hermenegildo de Brito Capelo (1841-1917), oficial de Marinha, que foi ajudante de campo dos reis, sucessivamente, desde D. Luís. Grande amigo do segundo António Sérgio de Sousa, foi, como este, vice-almirante e ajudante de campo do rei $D$. Carlos.

França - José de Campos França, oficial de Marinha. Colega de curso e amigo íntimo de António Sérgio e de Frederico Pinheiro Chagas. Era primo direito do Prof. Carlos França, eminente naturalista; Aquando da Revolução de 1910 não quis embarcar; ficou na Guiné e morreu lá com a febre amarela $\left({ }^{21}\right)$. Foi este amigo quem decidiu editar a primeira obra de Sérgio, Rimas. E o próprio António Sérgio quem o refere: «Jamais me propus publicar poemas. Compunha-os para mim, por necessidade interior (... \}. Foi um grande e excepcional amigo que decidiu editá-los à sua própria custa (com resistência minha), servindo-se de manuscritos que lhe tinha eu dado, e que ele coleccionou e organizou» $\left({ }^{22}\right)$.

- Frederico ou Chagas - Frederico da Silva Pinheiro Chagas (1882-1910) era filho de Manuel Pinheiro Chagas e suicidou-se aquando da proclamação da República. Também grande amigo e colega, na Marinha, de António Sérgio, o qual, nestas cartas, menciona outros membros da família Pinheiro Chagas.

- Lopes de Mendonça - Vasco Lopes de Mendonça era filho (io. poeta e dramaturgo Henrique Lopes de Mendonça e foi amigo de António Sérgio desde o tempo do Colégio Militar.

- Monsarás - Deve tratar-se de Alberto de Monsarás (1889-1959), 2. ${ }^{\circ}$ Conde de Monsarás, filho de António de Macedo Papança. Note-se que Alberto de Monsarás já em 1909 publicou um livro de versos, Romper de Alva.

- Ottolini - Foi único Visconde e $1 .^{\circ}$ Conde de Ottolini, Manuel Sarmento Ottolini (1840-1898). Não se trata deste, nem, pelas datas, pode ser nenhum dos condes deste título.

- Ramos - Manuel Oliveira Ramos (1862-1931) foi major do Exército, Professor do Curso Superior de Letras e do Colégio Militar.

(18> In Verbo, Enciclopédia Luso-Brasileira de Cultura, vai. 17, coluna 1226.

(19> Vd. nota 9.

$\left.C^{2}()\right)$ Agradeço muito vivamente a ajuda que me foi prestada, mediante o fornecimento de elementos sobre membros das famílias de António e Luisa Sérgio, por meu primo Raimundo Waddington de Qüintanilha e Mendonça, médico e genealogista, cujas valiosas notas foram imprescindível meio de estudo, e por minha mãe, Carlota Matilde Sérgio Pessoa de Figueiredo.

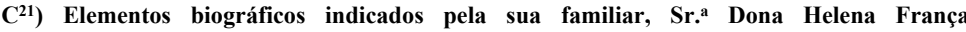
Rodrigues da Silva.

(") Ensaios, tomo VII, Lisboa, 1954, pp, 12-13. 
- Sílvio Romero - É o célebre escritor e filósofo brasileiro

- Henrique de Vilhena - É o conhecido professor universitário Henrique Jardim de Vilhena (1879-1958), o qual era então professor de Anatomia Artística na Escola de Belas-Artes de Lisboa.

\section{ALGUMAS OBSERVAÇÕES FINAIS}

Interessará aos leitores, porventura, saber qual a origem destas cartas. Apesar de sobrinha-neta de António Sérgio, só por um feliz acaso pude salvar estes documentos, que reputo bem valiosos. Foi em 1973 que encontrei vária documentação de António Sérgio colocada numa arrecadação de casa familiar: um sobrinhito fora-a desencantar para brincar, amachucando uns "papéis», que a empregada se preparava para deitar ao lixo. Por sorte deparei com esta cena, vi que se tratava de documentos - principalmente cartas - que me pareciam de interesse e evitei a sua perda. Entre esses documentos estavam as cartas de juventude que agora se publicam.

Mal os encontrei, dei disso conhecimento a meus pais e tios, sobrinhos directos e herdeiros de António Sérgio $\mathrm{t}^{23}$ ). Iniciei logo a transcrição das cartas, em vista à sua publicação. Contactei depois editores- entre os quais a editora que está publicando as Obras Completas —, investigadores da obra sergiana, em vista à publicação das cartas, mas nenhum por isso mostrou qualquer interesse.

Uma segunda observação respeita ao critério seguido nesta publicação. Por falta de tempo, deixou-se para outra oportunidade a anotação mais aprofundada dos textos - sem prejuízo dos elementos antes fornecidos para sua leitura e interpretação - e a edição de outros, que melhor poderão completar esta rica série epistolográfica.

$\mathbf{E}$, todavia, sempre difícil avaliar a conveniência da publicação de textos deste tipo. Um critério defensável é o de que, dos homens célebres, "até interessam as contas de alfaite» (citando, de memória, Eça de Queirós); e o de que o direito do público à verdade prevalece sobre quaisquer outras considerações.

Procurei, todavia, não fazer uma aplicação cega destes critérios. A leitura destas cartas revela por vezes comentários agudos e mordazes: julgo, porém, que mesmo alguma observação menos lisonjeira para uma ou outra pessoa não deve ser entendida como tratamento desagradável, com o qual se magoem pessoas a elas ligadas por parentesco ou laços de afeição. Há apenas a comunicação de pontos de vista de António e Luisa Sérgio, que interessam sobretudo como expressão de reflexões ou juízos, para nós relevantes culturalmente, mas já sem dimensão pessoal, aliás nunca pejorativa ou deprimente.

Poderão alguns dizer que só haveriam de publicar-se estas cartas decorridos muitos anos, quando fossem já remotos e frios antepassados as pessoas a que elas se referem. No entanto, com tal entendimento estar-se-ia a furtar aos estudiosos e à cultura nacional elementos de valia para o entendimento da personalidade e do pensamento de Sérgio (não tanto na perspectiva, nada sergiana, do pormenor biográfico, mas no do entendimento da génese, rica, concreta e mesmo palpitante, de um pensamento vivo que foi o seu).

(23) Os sobrinhos, filhos de sua irmã Juliana, são quatro: José, Maria Adelaide, Carlota Matilde e António (por ordem de idade, como se pode ver na fotografia agora publicada). 
Acresce que estes documentos, significativos e genuínos, só são abonatórios para a personalidade cultural $\mathrm{e}^{\wedge}$ moral de Luisa e António Sérgio - na sua relação a dois, e nas relações com terceiros $\left({ }^{24}\right)$.

Entendo, enfim, que o primeiro centenário do nascimento de António Sérgio é um forte ensejo para assim participar no que deveria ser um esforço nacional de conhecimento crítico do seu pensamento e valor ação da sua obra (esforço de que me parece exemplar - embora bem mais excepcional do que seria de desejar - este número da Revista de Historia das Ideias).

Todavia, em raros casos, optei por não transcrever agora alguns textos - que aparecem assinalados com $\quad\left({ }^{25}\right)$. Pesaram nisso motivos de carácter familiar, que julgo atendíveis: note-se, contudo, que em caso algum os textos omissos o foram porque contivessem fosse o que fosse de menos conveniente ou pouco abonatório para Luisa e António Sérgio, e que esta decisão também em caso algum prejudicou o interesse cultural e humano das cartas.

\section{Matilde Pessoa de Figueiredo Sousa Franco}

i24) Em aditamento à biografia de Luisa Sérgio, indica-se que António Sérgio escreveu, do Rio de Janeiro, a Álvaro Pinto, em Janeiro de 1914: «Consegui convencer minha mulher a rabiscar uns artiguinhos populares de educação»; em Junho de 1916 informa, de Genebra, a Manuel da Silva Gaio, que e'a «está fazendo nas escolas de aqui, sob a minha direcção, os seus estudos regu'ares, teóricos e práticos, de pedagogia e psicologia» e a Álvaro Pinto informa que Luisa Sérgio «se matriculou na Universidade e num Instituto especial» para adquirir «no assunto uma certa competência especial, que lhe permitirá fazer trabalhos um pouco mais decentes do que se fora uma simples curiosa». Estes elementos podem encontrar-se no documentado artigo de Lopes Rodrigues, "António Sérgio de Sousa Júnior», in Dicionário Biográfico Universal de Autores, vol. 4, ed. Artis - Bompiani, 1982, pp. 3215-3222.

(25) Além desta, outras convenções e abreviaturas muito simples foram adoptadas, no que pretendeu ser uma edição rigorosa mas, por imposições de tempo, nunca aspirou a tòrnar-sé em edição crítica. São elas: [ ] * c carta datada pelo dia do carimbo do correio; [ ] - carta que se encontrava datada a lápis; ()—data tirada a partir do contexto; s. d. - sem data. 


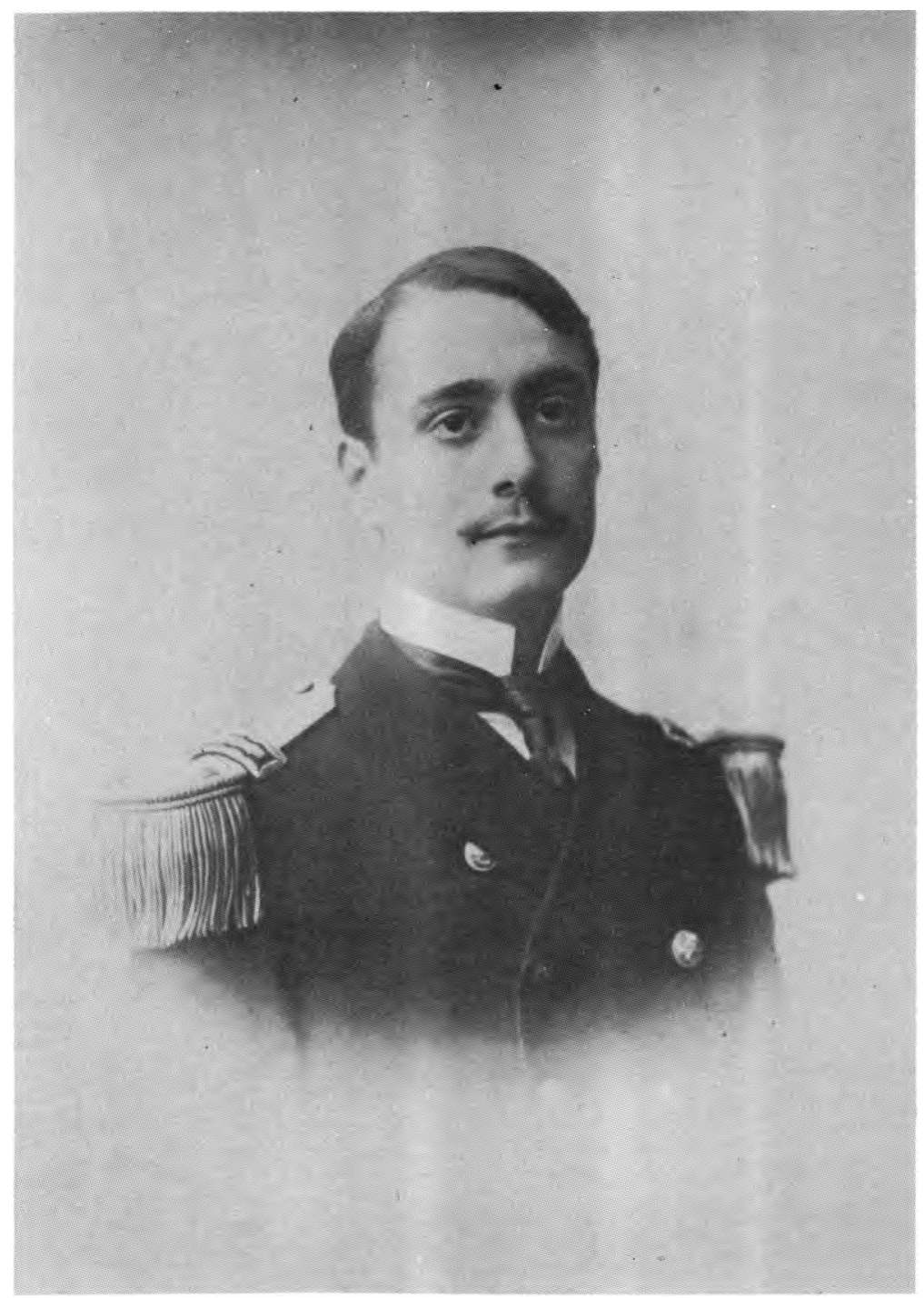

António Sérgio, quando oficial de Marinha 
(Página deixada propositadamente em branco) 


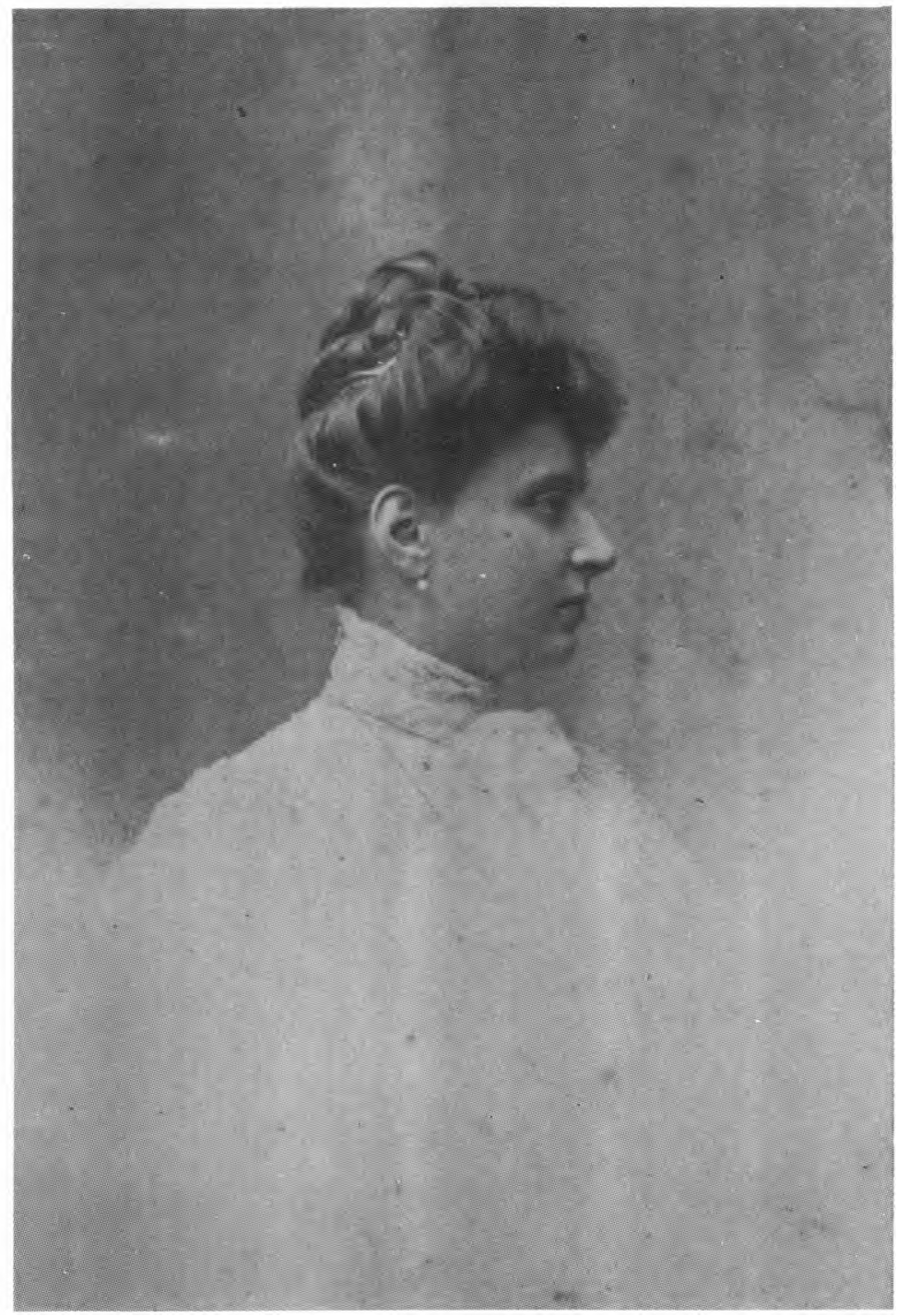

Luisa Estefânia da Silva Sérgio, mulher de Antonio Sérgio 
(Página deixada propositadamente em branco) 
Ex. ${ }^{\text {ma Senhôra }}$

D. Luisa Stephania da Silva

Casa dos Vargos

Correio de Torres Novas

[Lisboa, 18-10-02] *

\section{Minha Senhôra}

Para diversos casos, numerosos e variadíssimos, está consagrada a expressão "tomar a liberdade». Assim eu, escrevendo esta carta a V. Ex. ${ }^{a}$, tomo uma liberdade. Nem mais, nem menos - Isto será talvez, segundo as regras, um atrevimento dos de peor especie, em extremo necessitado do perdão que a sua bondade houvesse por bem conceder-lhe; quanto a mim provaria, quando muito, que tomo liberdades com a espontaneidade, facilidade e simplêza com que a gente que se preza toma banhos de Caldas e toma aguas. Que o chiquismo, na economia animal, manifesta-se pela dyspepsia. - Bem imaginada coisa! -

Valho-me desta vez de tal expediente para lhe comunicar que deverá receber pelo correio o volumesito da "Casa de boneca" de que nos Vargos lhe fallei, e lhe pedir que acceite a homenagem do seu servo e admirador

[a parte inferior da carta está rasgada, no local onde se encontraria a assinatura]

\section{CARTA DE LUÍSA STEPHANIA A ANTÓNIO SÉRGIO}

\section{Snr. Sergio,}

A sua gentileza e amabilidade captivaram-me immensamente e devo confessar-lhe que fiquei ....* ao receber o volumesinho tão desejado. Escusado será dizer que o principiei a ler logo, e com o maximo interesse fui seguindo e admirando a maneira por que Ibsen nos faz conhecer as suas personagens e tão magistralmente nos descreve as emoções porque vão passando. É terrível e empolgante aquelle desencadear subito da tempestade, que tão gradualmente se vae formando no horizonte desde o principio do drama.

Sabe Snr. Sergio? Supponho que na maior parte das vezes dar-se-hão coincidencias em que não faço reparo nem lhes presto a minima attenção, mas em certas occasióes tudo se nota, ponto é que a nossa alma esteja no seu posto d'observação: Esta manhã quando pensava justamente na "Casa da Boneca» entregaram me uma carta d'Allemanha em que me fallaram d'um caso muito parecido com o que conta Ibsen, que se deu ha apenas alguns dias. Não teve o

\footnotetext{
* [Degível]
} 


\section{António Sérgio}

mesmo desenláce porque felizmente casos d' estes não são vulgares, mas comprehendo a transformação completa que soffreu a alma d' aquella mulher no momento em que ella se apercebeu da terrível realidade. E quantas vezes se dão em volta de nós casos semelhantes que nos passam completamente despercebidos?

Mas agora reparo que lhe estou roubando o precioso tempo, deixei-me levar pelo enthusiasmo. Tenha paciencia!!! Não lhe faz falta o livro, posso conserval-o mais algum tempo não é verdade?

Creia-me sua dedicada

$$
\text { Luiza Stephania da Silva }
$$

\section{3}

Ex. ${ }^{\mathrm{m}}$ a Senhora

D. Luisa Stephania da Silva

Casa dos Vargos correio de Torres Novas

Portugal

Macau, 4 de Setembro de 1905

Minha Senhora:

Também eu hoje lhe queria fazer «votos»: mas não acha uma arrelia que os nossos «votos» sejam inúteis, e que a felicidade se não obtenha por chapeladas, como as cadeiras de deputado? Se assim não fôsse havia de ser eu o seu mais fervoroso galopim. Fica-me a esperança de que $V$. Ex. ${ }^{a}$ o acreditará, e de que me perdoará o não lhe saber dizer coisas mais bonitas; - que cada um é como Deus o fez, e ainda peór muitas vezes, como já dizia o bom Sancho.

Todo este circuito vem a significar afinal que é dos mais patetas, mas em compensação dos mais dedicados,

$$
\text { O seu mesquinho servo }
$$

\section{A. Sergio J.or}

À Ex. ${ }^{\text {ma }}$ Senhora D. Luisa Stephania da Silva - dalla bella voce distincta cantora de «Novembre»

\section{NOVEMBRO}

Novembro vem; e foi num mês assim

Que vendo o teu sentir no teu sorriso

Julguei, sem t'o dizer, um paraíso

Junto de ti

Novembro vem - Quem nos houvera dito!

Não é certo que fomos bem creanças?

Como é bonito um sonho d'esperanças!

Como é bonito! 
Novembro vem; - sentado no meu canto,

Doente e só, revi nos sonhos meus

Aquelle inverno em que eu amei a Deus, E chorei tanto!

Novembro vem; - e vem a occasião

De pôr algumas flores num mausoléu...

Direi por um pobre sonho que morreu

Uma oração!

Traducção de Novembre de P. Bourget por

A. Sergio J.or

Vargos, 3 de Julho 1906

Cumpro, Senhora, o dever

De mandar os promettidos

Versos, de ha muito nascidos,

Ahi num canto escondidos

Com vergonha de vos vêr:

São maus, sandeus e torcidos.

Se toada nunca houver

Com que possam ser cantados

Não vos dê isso cuidados,

Serão de tudo adornados

Se a vossa bôcca os disser:

Que mais musica hão mister

Que ser de vós recitados?

Antonio Sergio

18-1-908

6

\begin{abstract}
ALVORADA
Mal sente a terra a luz da fresca Aurora

Beijar as gôttas d'água, que evapora,

E saltitar risonha nos seus flancos,

Appareces-me tu, minh'alma airosa,

Nas pontinhas dos pés e cautelosa,

Mostrando-me a sorrir uns dentes brancos...

Vens de não sei que mágicos paizes

$E$ fallas-me tão bem... Não sei que dizes

Mas é como um cantar tão bom, tão brando...
\end{abstract}


Respondo-te enlevado, como em sonho, Mil coisas desligadas, mas supponho Que estás ouvindo attenta e vaes gostando...

E giras como fumo ao vento, emquanto, Rodopiando, as dobras do teu manto Os meus olhos de manso acariciam...

- Que feliz despertou como eu desperto?

Eram tal qual assim, pois não, decerto, As coisas que se diz que os santos viam?

Com gesto serpentino, sobre mim Vaes desfolhando as rosas de um jardim Guardado por magia, encantamento, Onde só entras tu, porque uma fada Te fez imponderável, fluida, alada, Como a luz do luar e como o vento...

Mas n'um prompto - ó dolosas fantasias!

Como as palavras vãs que me dizias Teu corpo s'esvahiu também no ar... Fiquei na solidão co'as minhas penas, Que para mim o bem é sonho apenas E já não posso em nada acreditar:

Eu vivo só d'idéas insondáveis, Só tenho crença em formas impalpáveis, E quem n'um raio d'ouro me fallou Ai não és tu, não és, mas tão somente Uma imagem subtil que a pobre mente N'um ondular ethéreo me forjou.

Antonio Sergio

\section{A UMA DAMA}

Deu-me hoje a desvairada tontaria De poetar também; dizer, Senhora, A uma dama gentil de trança loura As doidas semrazões da fantasia...

Mas antes, por temer a zombaria, $E$ vos saber de tudo entendedora, Pensei em vos tomar por julgadora: Se - para vos ouvir - vo-las diria...

E pois que em bom censor sempre ha branduras Vou desprender, Senhora, estas loucuras Que trago dentro d'alma encarceradas... 
Ai de mim, que não sei o que prometto

Porque em summa, são coisas complicadas

Que não cabem nas rimas de um soneto.

Junho (?) 1908

8

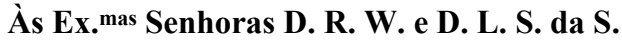

Vêde rompêr nos montes a manhan,

Que dôce e boa à terra se avisinha,

$E$ no oscillante ramo uma àvesinha

Cantando a luz de Deus que vem louçan!

Assim qualquer de vós, que a lei christan

Com transporte e fervor no peito aninha,

É aurora que explende e me acarinha,

Mestre, guia, senhora, e minha irman;

E até, se em somnos máos que maguas são,

Na taciturna paz da solidão

Rólo em sonhos de dor a noite inteira,

Cá vos sinto passar nas minhas feridas

Com mimos de creança e de enfermeira, As caridosas mãos compadecidas.

Vargos, 17-8-08

\section{OS BOIS}

«Le songe intérieur qu'ils n'achèvent jamais»" L. de Lisle.

Sobre vós, bois d'olhar manso,

Que branda que a noite vem!

Nos ramos, nem um balanço,

No vasto ceu que descanço!

E que paz em vós também!

O plaino é calmo e saudoso:

No fundo já quasi dorme

A serrania em repouso, $\wedge$

Curvando o corpo anguloso

Qual, sopito, um monstro enorme. 
O tectosinho inclinado

Vae mergulhando na sombra:

Contempla o dono, enlevado,

Sobre o horizonte encarnado

$A$ vastidão que o assombra.

Na pôça d'água estagnante

Revê-se a herva pendida,

A claridade expirante,

E a nuvem do ceu distante

Que perpassa esmorecida;

Na ramada, a cantilena

Que lhe diz a viração:

Em vós, bois d'alma serena,

Quando vem a tarde amena

Se reflecte a Creação!

Sonháveis, ao sol nascente,

O que andais sonhando ainda...

Segui, bois, tranquilamente

Na vaga luz d'essa mente

O sonho que nunca finda!

\section{Á ILLUSÃo}

Imagem formosíssima e celeste

Que pelas serras negras vaes assim,

Entre o cardo da dor e a mágua agreste,

Mudando a selva bruta num jardim;

Apparição donosa e sempre amada

Que nos salvas, nos guias, nos redimes,

Que dás á terra inhospita e queimada

Um reflexo da luz dos ceus sublimes.

Tu que esplendida fulges como a aurora, $E$ tens do entardecêr toda a doçura:

Que ao peito sonhador, que mais te adóra,

Fallas plena de graça e de ternura;

Tu, fada milagrosa, ovante e bella

Que, se vaes a mansão de acérba lida

E logo a mais escura e estreita cella

Em fabuloso alcácer convertida:

Que tens no albirosado e casto seio

Doce leite de amor que nos consola

Do mal, da solidão, da dor, do anceio

Que a inquieta insómnia desvairada rola: 
Tu, deusa lirial de rósea bôca

Que tens nos finos lábios um tesoiro

Em que ri venturosa a esperança louca,

E guardas a chimera em cofres de oiro:

Bemdita sejas, illusão sagrada,

Que o mundo levas arrastado aos pés:

Por cada passo deixarás gravada

Etherea gemna de preciosa estrada

Que todos miram sem sabêr quem és!

Inspiradora das visões fecundas,

Da coisa ao homem, claramente ou não,

Nos ceus radiantes ou nas aguas fundas,

Por ti, bellesa que de amor inundas,

Todos com éxtasi attrahidos vão!

Riquesas, glória, resplandor, ventura,

Nos mostra em névoas o teu braço amigo:

$O$ jóven, crendo que te tem segura,

Exulta: aos velhos, sobre a sepultura,

A morte encontra-os a sonhar comtigo!

Tens mago filtro que os amantes guinda

A um sonho louco, sobrenatural:

Vê Julieta, como está tão linda!

Creança loira desvairada ainda

Pela mentira do amor ideal!

Que'importa que esses, quando emfim colhida

A rosa bella que a paixão formou

A sintam logo murchecêr pendida?

Seus filhos todos seguirão na vida

$\mathbf{E}$ [sic] mesma estrella que os descaminhou!

Bemdita sejas, illusão sagrada,

Que o mundo levas arrastado aos pés:

Por cada passo deixarás gravada

Ethérea gêmma de preciosa estrada

Que todos miram sem saber quem és!

Para alem destas frases de ironia

Tão cheias de frieza e d'esquivanças,

Sou carinhoso e bom como as creanças...

Mas bem outro me tens na fantasia!...

Escuta: Sendo eu morto, um aureo dia,

Do tropel d'illusôes e d'esperanças

Voltada de repente a más lembranças,

Virás resar-me à cova humilde e fria... 
Sim, meu amor, virás... vens sim.... Perdoa

Mal sabes como esfaima te abençoa

Vendo-te ajoelhada, em sonho...

Num murmurar dulcíssimo direi Então,

Tudo que tenho a arder no coração

$E$ te não digo já, porque não sei...

\section{AMÔR E MORTE}

«Tout être qui aime n'acquiert-il pas un titre à l'immortalité?» Guyau

«Está no pensamento como idea»

Camões

\section{I}

«Para alem d'estas frases d'ironia,

Tão cheias de friêza e d'esquivanças,

Sou carinhoso e bom como as crianças..

- Mas bem outro me tens na fantasia...

Escuta: sendo eu môrto, um aureo dia,

Do tropel d'illusôes e d'esperanças

Voltada de repente a más lembranças,

Virás resárme á cova humilde e fria...

Sim, mer amor, virás... Vem sim... Perdoa:

Mal sabes como esfaima te abençoa

Vendo-te ajoelhada, em sonho...

Num murmurar dulcíssimo direi

$$
\text { Então }
$$

Tudo que tenho a ardêr no coração

E te não digo já, porque não sei...

II

Não sei, nem sabe alguém... Do teu pensar

Hão-de surgir o canto e a forma alada:

Não pode em lingua humana sêr narrada

Essa harmonia que fugiu no ar...

Se a minha imagem viva em ti ficar Já não terei, meu bem, descido ao nada:

Transformase o amador na coisa amada

Por virtude do muito imaginar...

Vencendo o transitório e vagabundo,

E dos momentos vãos a van cohorte,

Terás feito o mais bello e mais profundo 
D'entre o sonhos [sic] que a alma oppõe á sorte:

Ditar o coração a lei ao mundo,

O amor, eterno, triunfar da morte!»

Antonio Sergio

[25-3-09]

Ex. ${ }^{\text {ma }}$ Senhóra

D. Luisa Stephania da Silva

P/E./O.

Recebi hontem, Senhora minha, as duas estimadas estampas que têve a graciosa teimosia de me offerecér:

Por as águas do eterno esquécimento

Segura passará minha lembrança.

Pezarôso por ter truncado a sua collecção, espero vê-la recomposta a primeira vêz que tivér a honra de a visitar.

Entreguei à prima Ruth, para fazêr o obsequio de lh'a restituir, uma carta para si que foi encontrada num livro que me emprestou: Caminho do Ceu. Mil recomendações do seu humilde servo obrigadíssimo

Antonio Sergio

s. d.

Minha Senhora:

Não sei se lhe succede affeiçoar-se às criaturas sem esmiuçar muito se as estima como a um pae, a um filho, a um tio, a um primo ou a um irmão... Questões de casuistica sentimental, de que fujo um pouco. Não assim com o que se chama o mundo, que exige que entre um homem e uma Senhora haja exclusivamente duas situações admissiveis: ou uma completa e cerimoniosa indifferença, ou um sonho de noivado, declarado e official. A primeira hipótese não a desejo com sigo, porque a estimo e respeito; e quanto á segunda, sabe V. Ex. ${ }^{a}$ muito bem que nunca me deu confiança para eu têr o atrevimento de pensar nella, e que mesmo que assim não fosse, bastaria a minha situação social hoje para que a consciência me obrigasse a addiar essa idea, deixando a porta aberta ao futuro e á illusão...

Ora, voltando ao nosso caso: tenho a certêza de que o facto de me falar e de me ouvir a hade expôr a sêr alvejada por ${ }^{\wedge}$ pequeninas insinuações leves... Que quer que façam, minha Senhora, duas honestas más linguas em conversa? Nem sempre se hade tratar de arte, ou de sciencia, ou de caridade, ou de politica, ou das coisas sociaes, ou das letras... Eu nada tenho a perdêr com isso, e se pudesse envaidecêr-me com tão sérias coisas, só me succederia inchar 
todo de infatuação e vaidade. Mas não posso afazêr-me a que por minha causa gire o seu nome entre os dentes de um maldoso, - ou de uma maldosa... Comprehendo que a sua natural independencia se revolte contra a sujeição a o que se diz. Ao mesmo tempo a sua delicadeza teria receio de me ferir se me tratasse diante dos outros com muito cerimoniosa indifferença, - essa que usamos com as sociáveis pessoas que nos são apresentadas na soirée do Snr. Fulano... Venho pedir-lhe que o faça: faça-o para o publico. Diante do mundo- cumpra o que o mundo ordena. Desde que assim procêda a meu pedido, não tem a receiar ferir-me. Devo querêr sujeitar-me a isto. Fico assim com a consciencia mais tranquilla a seu respeito.

Fossem quaes fossem as situações em que eu para mim mesmo me colocasse, era minha obrigação ambicionar para si (em relação a si e em relação aos outros) uma liberdade completa, e vê-la a coberto de todas as supposições, ao mesmo tempo que pudesse acompanhar a sua vontade e seguir as suas ideas. Compete-me procurar que a sua caridade para commigo lhe não possa causar o mais pequeno embaraço. Talvêz venha a precisar um dia de me fazêr sentir que me devo affastar um pouco: era para si uma difficuldade e para mim um desgosto enorme. De todas as situações se pode dizêr que é inútil e mau que o publico tenha conhecimento e espectáculo. Veja bem, minha Senhora, e seja feita a sua vontade assim nas pessoas como nas coisas. As nossas ideas dependem de nós; as dos outros são um misterio; e as circunstancias são a Fatalidade...

Oxalá me tenha entendido completamente e bem. Ao principio heide parecêr-lhe atrevido, descarado e bruto; talvez depois se convença- modéstia á parte - de que fui arrojadamente limpo, consciencioso e nobre. Garanto-lhe que, se sou capaz de procedêr com abnegação completa, estou procedendo agora assim. Olho exclusivamente á sua liberdade, ao justo orgulho que deve têr, á sua maxima tranquilidade, ao respeito absoluto que dos outros merece. Este caso de um homem acautelar d'esta forma uma dama a propósito de si mesmo é talvêz unico. Vejo que sáio das normas, mas as normas não são para se usarem em todos os casos, nem por todas as pessoas, nem com todas ellas.

Seu muito dedicado e respeitoso servo

Antonio Sergio de Sousa.

Minha Senhora:

[14-5-09]

Não me fiz comprehendêr bem. V. Ex. ${ }^{a}$ não praticou tal exaggêros. Protesto contra essa interpretação das minhas palavras. As suas falsas amigas é que do simples facto de falar commigo em casa das tias se aproveitavam já para cevar voluptuosamente a sua baixa inveja. Para mim, para o meu julgamento, andou sempre admiravelmente- vê bem?- - admiravelmente. Não me attribua o mesquinho criterio da gente linguareira. $E$ exactamente porque subia na minha consideração é que me custava muitíssimo, - mais do que se julgaria natural, bem mais do que pareceria legítimo, muito mais do que pode V. Ex. ${ }^{a}$ imaginar, - por isso é que me custava immenso o sabê-la 
alvejâda pela criticazinha. Em resumo: á medida que eu pensava em a elevar dentro do meu coração, mais me custava vêr nos outros essa elevação desrespeitada.

Diz-me «que a norma the não serve, porque se lhe afigura indigna de um sentimento puro e verdadeiro tal comédia e tal fingimento». Ora até que emfim! No meio das preocupações que a sua carta me, deixou, quasi soltei nesta passagem uma exclamação de victoria! É isso mesmo que eu queria ouvir, e é isso mesmo o que eu penso. Para a satisfação sêr pleníssima só me bastava têr a certêza de que julgava tal em virtude do apreço e da confiança que a minha maneira de sêr lhe inspirava. Infelizmente, desanimei outra vêz quando li a frase: «julgo que falei de mais». Porquê? Se falou verdades não podia têr falado de mais. Não tenha commigo preoccupação alguma reservada, nenhum mêdo, nenhuma desconfiança. Garanto-lhe que a minha attenção é límpida como cristal. Amor próprio nenhum, vaidade nenhuma, nenhuma malícia.

Diz que me não comprehende muitas vêzes, ficando hesitante no pensamento. Quero-me confessar. Vae sorrir-se talvez da ingenuidade, quasi direi criancice da minha confissão. Tenho dois deuses em mim, duas urnas, duas chammas: a paixão da bondade, e a paixão do ideal das almas cândidas. Quereria realizar alguma coisa muito transparente na amizade, no amor, no pensamento. Já hoje attingi uma, e foi a amizade. A do pensamento hade trazêr-me ainda muitas luctas, muitas indecisões, desalentos, dúvidas, - e no fim, naturalmente, a derrota... E no amor, - oh meu Deus, como encontrar a criatura Única que se sujeite a uma tão difficil educação de si mesma, para realizar commigo a perfeita união de duas almas que não é a paixão, nem talvêz ainda o que se chama vulgarmente o amôr, nem nada do que quasi todos poderão sonhar, porque é a absoluta identificação obtida por um tenacíssimo esforço de vontade intelligente e calma? Este meu sonho não tem a bellêza dramática da paixão vulgar, _ porque tem a magnificência sublimissima da idéa. Para se escravizar á minha extravagância, era necessário numa mulher o sêr tão maluca como eu, e têr muito mais bondade, muito mais energia, muito mais abnegação do que eu tenho. Não merêço que se faça por mim tal sacrifício; - é verdade, mas seria esse o meu sonho... Alguém que se compenetre d'isto: só vale o que é alma, e é preciso realizar pacientemente a identificação, a transubstanciação, a xransfusão absoluta de duas almas. Isto, minha Senhora, não é coisa que eu procure encontrar feita: é obra que é preciso tentar-se, que é preciso fazêr-se lentamente por uma educação laboriosa de nós mesmos. Quando tal se obtivesse, á força de franquêza e de lealdade, parece-me que não haveria verdadeiro amôr de Deus que pudesse sêr contrariado. Eram dois a amar a Deus, o misterioso Deus das almas...

Atire pela janella as desconfianças mundanas, medite, creia, e responda-me

\section{Pensieroso}

P. S. Estava esta escrita e fechada quando lhe falei ao telefone. Digo-lhe, para se achar conveniente dizêr-me qualquer coisa, que estou de serviço durante a noite. Depois de àmanhan pernoito no Quartel. 
Minha Senhora:

Vejo que me não comprehendeu por enquanto. Não tem nada que luctar, porque não tem nada que decidir (a meu respeito). A decisão Vem depois, e não no principio. Não vê que isso seria cair logo no compromisso, na sujeição, na mentira? Já the disse que deverá conservar-se livre sempre, e reconheço que ainda não percebeu talvêz porquê. Nunca eu pensaria em lhe pedir, como qualquer outro, que me namorasse, mas exactamente o contrário. A única coisa que teria a fazêr, se quizesse, era conhecêr-me, e para isso não precisaria de sair da sua attitude até hoje.

Não creio que, como diz, se lhe depare agora a felicidade. Duvido, pelo menos. A criatura rarissima que é o homem puro, quando lhe succede sêr, como eu, atormentado e exigente, tem seu quê de parecido com os logares saudáveis e onde se respira bem: não são sempre os mais risonhos. Nas nossas circunstancias actuaes seria até para si (por outras razoes) uma grande infelicidade.

Não se préoccupé com coisa alguma, sinta em si corrêr a vida. Viva no presente, $e$ não no futuro. Seja alegre. Trate muito da sua saude, com o ideal de realizar o que direi sêr, imitando o poeta,

Le souffle de Platon dans le corps d'Aphrodite,

a aima de Platão num côrpo de Afrodite. Seja muito simples, muito boa, muito sincera, sempre, com todos, e com sigo antes de todos. Estude, mas sem se cansar, as coisas bellas, lembrando-se da frase da Catharina de Sienna. Veja sobretudo que não ha nada de que estar preoccupada, apressada, indecisa, pelo que me respeita... Póde esperar, indefinidamente, por isso a que chama a inspiração do Senhor.

A sua frase: "é esse o meu ideal e sempre foi» veio remoêr-me uma chaga antiga. Paciência. Está decidido que a vida destrua em mim, por completo, a divina faculdade do enthusiasmo. Esse caso triste faz-me tanto desconfiar! Chego a perdêr por completo a esperança de que me possa vêr bem. Julgou esse biltre, naturalmente, tão digno como me julga a mim, e se fossem outros os successos seria capaz de julgar outros... Não quero seguir hoje no assumpto. Repare que não ha aqui também de que incommodar-se por minha causa. À força de vontade estou, por assim dizêr, anesthesiado: já as coisas felizmente me não trabalham com aquella extrema violencia antiga.

Perdoe. Bom dia. São 5 da manhan, e, como de costume, toda a noite acordado. Amanhan, 18, estou de serviço.

A. S.

«O intelecto nutre o affecto. Quem mais conhece mais ama; e mais amando mais gosta»

Santa Catarina

(frase escrita num pequeno cartão) 
Senhora minha:

Foi tristíssima a impressão que me fez a sua carta de outro dia (mais tarde lhe direi porquê) e a de hoje, tão obscura, alegrou-me apesar de tudo, porque estava immenso receoso de que a tivesse magoado a minha ultima.

Preciso agora de esquècêr todas as dúvidas que me alanceiam, e deixar-me embebêr da imaginação fantasista, atrás de imagens fluidas que me fazem perdêr o pensamento. Sabe o que é um homem metamorfosear-se em vários sonhos e representar em si mesmo uma comédia longa, impalpável, indefinida, passada a qual lhe fica a impressão somente de uma poeira d'ouro que fugiu? Tenha paciência, e não me chame tolo. Passei a noite vagueando. Não achará muito poético, porque, primeiramente, foi na parada de um quartel; e depois, se vi, como qualquer bardo, as estrêllas de oiro e senti as brisas, atanasou-me a música fanhosa da feira de Alcantara que, de resto, acabou cêdo. Duas terríveis e positivas coisas. De vez em quando as sentinellas gritam alerta. Isto já tem seu ar aventureiro e épico. Se fôsse algum primitivo pastor longínquo dir-lhe-ia que tinha comparado os seus olhos a duas estrêllas scintillantes. Não comparei. Pois os Dioscuros lá estavam, juntinhos, a provocar a comparação. Fique sabendo que os Dióscuros eram dois manos muito amigos, Castor e Pollux, filhos de Leda, irmãos de Helena, a mais bella mulher que o mundo viu (um bardo não lhe diria isto, diria que era a segunda...) - a mais bella mulher que o mundo viu, e que suscitou, por suas volubilidades, uma terrível guerra na desditada Troia. Pollux era immortal; mas Castor, que o não era, muito naturalmente morreu. Desespêro do mano Pollux, que foi fazer uma grande imprecação ao tonante Jupiter. Finalmente foram transformados em estrêllas, ao pé uma da outra. Ora, é de sabêr que os Dióscuros foram propícios aos marinheiros, protectores das navegações, como agora, na nova crença, Santo Antonio o é dos noivinhos...

Hade dizêr que a história dos Dióscuros não tem graça. Pois engana-se, que tem. Pollux, não podendo conseguir de Jupiter que lhe immortalizasse o irmão, distribuiu com elle a immortabilidade: vivem, resuscitam alternadamente, ora um e ora outro... Notará que isto é uma dissertação, que divago e que extravago. Faltava mais de um quarto de hora para acabar o meu serviço quando lhe comecei a escrevêr, e não falta quasi nada.

\section{Ri, meio-occulta, a fresca Aurora, \\ Começa a noite a erguêr o veu: \\ Pállida, Venus nasce agora \\ Como uma lágrima do ceu.}

Aqui tem uma quadrinha que acabo de fabricar e que lhe mando de presente. Por desdita, é o único presente que posso fazêr, seja a quem fôr...

Afinal, cá vim a dar nas coisas sérias. Tinha bellas tenções de fugir da situação em que nos encontramos hoje. Eu sou quasi um mendigo e tenho - felizmente - minha irman e minha mãe. Vós, cordeirinha gentil, sois rica, e sempre vivêstes como tal. Francamente, francamente, não contando já com outras coisas, a menos de um 
milagre não lhe vejo solução. Não me queira mal, desejo que tenha dormido óptimamente a sua noite, e cerro-me agora porque já oiço lá longe o camarada que me rende. Vive et me ama, diziam os latinos para terminar. Eu não sei mesmo se lhe deva pedir que me ame

A. $\mathbf{S}$.

Cordeira minha muito amada:

Por quem é, meu amor, não se ponha a fantasiar coisas tristes, nem desate a apoquentar-se, porque me faz adoecêr de afflição. Fiquei com tanta vontade de a animar, de a alegrar, de a acariciar - como se acaricia uma rola pávida! Não me diga que a desgosto, porque me dá horror de mim mesmo. Fico a desconfiar que sou um monstro, quando não sou mais que um homem com a consciência muito nitida das suas responsabilidades com as almas. E esta constante $e$ contradictoria união de uma emoção muito viva com uma análise muito lúcida. Se não quer que lhe fale nessas minhas responsabilidades, procederei como manda, mas mais tarde não me accuse de não têr sido previdente. Bem vê, não tenho nada a perdêr com esse procedimento, e sêr-me-ia mais agradável deslembrar devêres severos que a mim mesmo me imponho, para só me deliciar na supposição de que me ama, e só the dizêr de todas as formas que lhe quero muito, o que, Deus meu, é tão fácil, - e, sobretudo, tão verdadeiro!

Tão verdadeiro, meu amor, tão verdadeiro! Como é que não percebe isto: que a paixão amorosa é nos homens o mais egoísta dos sentimentos, e que bastava eu deixar-me cair um nadinha nesse egoísmo, para logo vêr em tudo facilidade e vantagem? Pense claramente: em qualquer hipóthese futura, eu só teria a ganhar em procedêr de modo contrário ao que procedi. Veja lá. Não é verdade? E agora conclúa...

Atacam-me as emoções com tal profundidade que me abatem, mesmo aquellas que pareceria devessem exaltar-me. Preciso de cuidado em mim mesmo. Tenho quasi constantemente obrigado a minha alma a estar tendida, sempre, sempre, como um arco que sempre estivesse para despedir a sua setta. D'ahi o têr tornado o meu organismo mais delicado que as cordas de uma harpa em que se não póde tocar porque quebram. Não é possível a vibração contínua; fiz a tolice de exigir da vida o de que ella é incapaz por naturêza. E o resultado é este: não consigo escrever amo-a sem que me faça mal e muito mal. Tive que parar, vê, e ficou-me o peito quasi gelado.

Oiça, cordeirinha. Tenho sido muito estimado, por muita especie de gente e com muita especie de affeições. Tanto m'o mostraram, pelo menos, que acabei por acreditar. Pois preciso de que me ame muito mais que todos juntos, com toda a profundêz, todo o enthusiasmo, toda a seriedade da sua alma. Preciso ainda que todos os dias amanhêça com a alma mais profunda enthusiasta e séria. Não somente companheira da minha vida, quero que o seja a da minha sensibilidade e a da minha intelligência. É o logar mais vasto que póde dar um homem dentro de si, a alguém que desejaria fazêr bem maior do 
que é, muito maior do que se pode sêr. Não quero delirar, cordeirinha, adeus. Nunca pense mal de mim, e seja para mim muito verdadeira, muito compassiva, muito santa.

\section{A. $\mathbf{S}$.}

Ah meu amor, que verdadeira, que jovem, que fresca carta a sua! Recebi-a agora mesmo (nove e meia da manhan). Tenho a avisa-la de que não entro hoje de serviço, mas saio. Entrei hontem, porque adoeceu um camarada. Volto a entrar depois de amanhan, sexta-feira 28. Não posso sêr mais longo porque estou na faina de um auto que tenho de acabar antes do meio-dia. $O$ telefone tem o grave inconveniente de as meninas da estação serem muito curiosas e terem pouco que fazêr... Intende?

Quero vê-la sempre assim, alegresinha como um pintasilgo. Trate muito da saude. Faça-o por minha intenção, estrellasinha, e por isso com a dedicação recolhida de quem pratica um rito. Não the parece que todas as acções da nossa amizade deverão assumir um carácter religioso? E preciso que na nossa vida não haja um único momento de discordância ou de friêza, um unico acto que não seja attractive, uma única palavra que não seja amor.

Seu seu e seu

A. S.

Nós os dois sentadinhos num banco

Muito bem um ao outro a mirar

Teu ôlhito é tão claro e tão franco!

Toda a vida quem dera assim estar

Mas ai Deus tudo vae, tudo foge,

Toda a flor hade em breve murchar estamos?

Aqui vamos [sic] juntinhos por hoje, Amanhã onde iremos parar?

Já que tudo por fim leva à morte,

É com força o prazer agarrar:

Sabe Deus que depressa hade a sorte,

Um ao norte, outro ao sul, atirar!

Rascunho com letra de António Sérgio não datado. Veja-se carta de Luisa Stephania de 7 de Julho de 1909. 
Minha gemma:

Os autos não me fatigam, mas são coisas muito graves, conselheiraes, muito sérias, com escrivão, testemunhas a depor, juramento aos Santos Evangelhos, e que não posso largar a meio para ir regar o meu jardim...

Até agora (meio-dia) ainda me não appareceu hoje nenhum. Enquanto não arranjo coragem para entrar no Shelley tenho-me entretido a relêr um poucochinho de Shakespeare em traduçã̃o francêsa.

Mandei-lhe o Hamlet pela Pilar. Leia a peça attentamente, e a introdução do Mézières da página $171 \mathrm{em}$ diante. Estude com muito cuidado o carácter do protagonista, e mande-me dizer as suas impressões como se se tratasse de um homem com quem tivesse conversado. Simpatizou muito? Qual o seu feitio? Ficou-lhe sendo affeiçoada? Quereria tê-lo para amigo e conselheiro? Acha-lhe defeitos ? ${ }^{\wedge}$ Confiaria nelle inteiramente? A descripção do Mézières parece-lhe boa? A seguir ha-de lêr o Misanthrope de Molière, e comparar Alceste com Hamlet. Repare que lhe não peço apreciações literárias, sobre a factura das duas peças, profundidade de observação, convergência dos effeitos, simplicidade dos meios, poesia, justêza das fórmulas, etc. Supponha que Shakespeare e Molière não existiram, mas que Alceste e Hamlet são duas positivas criaturas de carne e osso com quem fez conhecimento. Qual the agrada mais? Qual the parece superior? Qual mais intelligente? Quero-a absolutamente franca, sem se importar a principio com as opiniões d'outrem. Não se canse, mas não seja preguiçosa.

Como tivesse conseguido lêr finalmente o João de Barros, na noite em que a vi em S. Paulo fui para casa e comecei a Ode aos Congressistas, que ficou prompta na manhan seguinte (perto de 200 versos). Nesse mesmo dia li uma recente obra do Delfim Guimarães e rabisquei uma noticiazinha sobre ella que para o Illustrado me pediram. Ainda não veio estampada, não sei se por falta de espaço, se por quererem que eu mesmo reveja as provas. Hoje ao chegar ao Quartel tive a suprêza de vêr que me tinham dado a honra de transcrevêr em artigo de fundo uns trechos do meu Anthero. Foi certamente gentilêza do Annibal Soares, redactor principal da folha e literato muito intelligente e simpático que ha tempo me foi apresentado. A propósito, não tenho tido paciência de indagar se o Liberal e a Lucta me criticaram já, como haviam promettido. Disseram-me que um dos ultimos números do Brazil-Portugal transcreveu o Claustro:

Aqui tem coisas pouco importantes, mas fui passando sobre ellas sem dar por isso. É verdade que assim correspondo ao tom da sua cartinha, que me agradou muito. Como quizesse escrevêr qualquer coisa para si, estive hontem a copiar pensamentos de vários autores num livro em branco que lhe hei-de dar. Porque não tinha outro em casa na occasião servi-me d'aquelle que o França me mandou aos Vargos para eu desenhar as árvores. Ha-de tê-lo à sua cabeceira e lêr duas linhas de vêz em quando. Ouviu? Não me engane...

Ai, minha Luisinha, cá me appareceu o auto. Tenho de interrompêr, sem saber se poderei ou não continuar logo a tempo ainda de mandar esta a horas. Antigamente recebia as suas cartas depois de entrar de serviço; agora já cá estão quando eu chego. É assim 


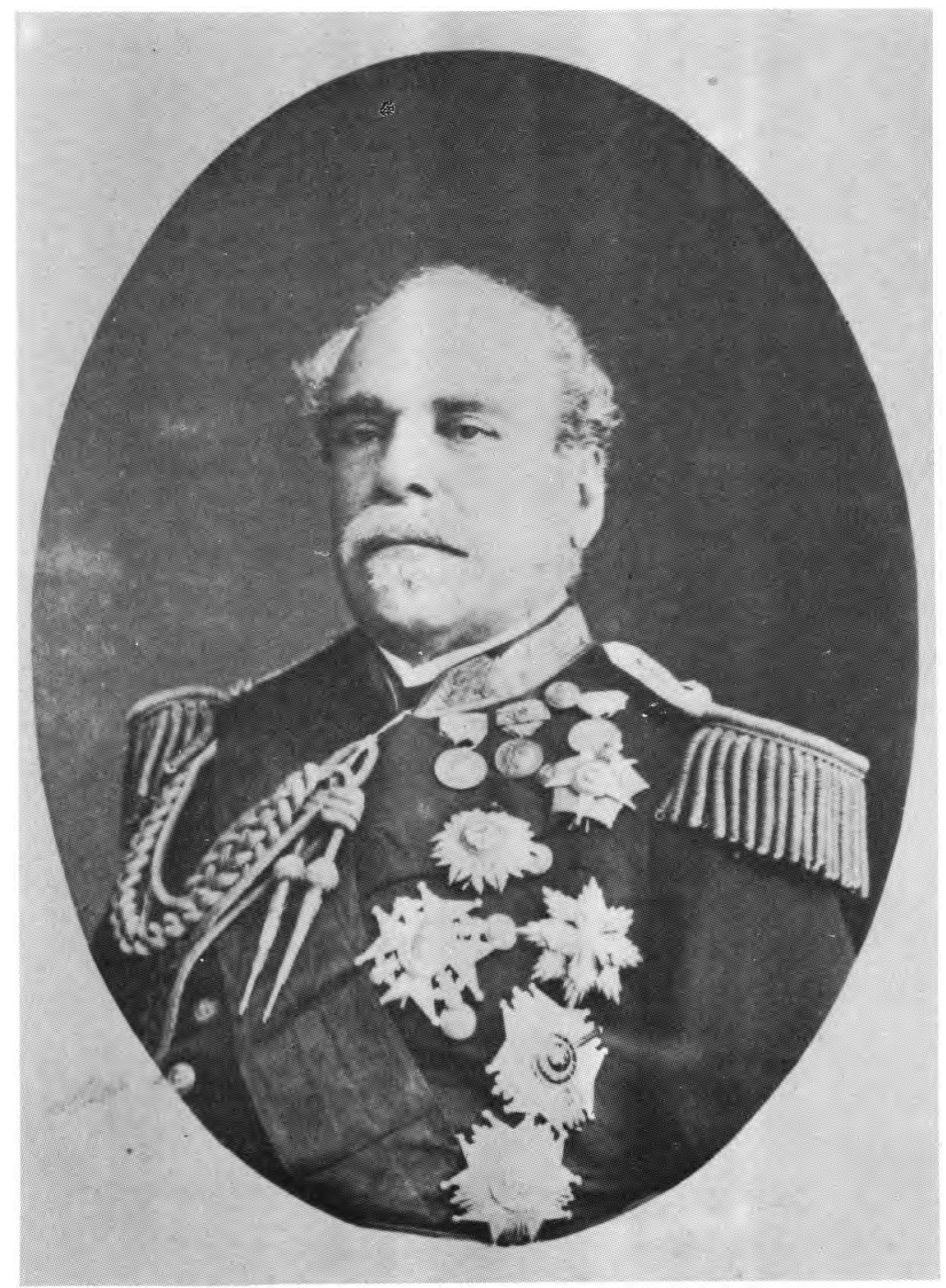

Almirante Antonio Sérgio de Sousa, avô de António Sérgio 
(Página deixada propositadamente em branco) 
melhor. Pense sempre em mim. O doux secret é melhor continuar o mais doux, e o mais secret possivel, para que o não profane a curiosidade dos mexeriqueiros e das mexeriqueiras. Não é esta a opinião da minha Luch?

Seu

\section{Antonio}

5 da tarde. Uf! Consegui libertar-me a tempo. Nunca mais me esquecerei d'aquelle seu: «Oh meu Deus, é tão bom!» da penúltima carta. Seja sempre absolutamente verdadeira comigo, e procure não se aborrecer do meu genio. Por algumas coisas a que os homens ligam grandissima importancia tenho eu um grande afastamento, mas perfeitamente natural, simples, espontâneo, sem a mínima sombra de pose, de desprêzo ou de orgulho. Não as desdenho por as achar pequenas ou baixas (bem ao contrário) mas, concordando que ellas teem o valor que os outros lhe dão, constato simplesmente que para o meu temperamento ellas passam despercebidas. Creio que me não espera o que se costuma chamar uma vida brilhante, d'estas de tentar os ambiciosos; mas quem vivêr commigo poderá têr um bem mais raro ainda: a serenidade d'alma, a limpidếz da consciência. E costume dizêr que o que faz a infelicidade de uma vida não são as grandes catástrofes, mas as pequeninas agonias caseiras e quotidianas. Pois bem: vejo que sou incapaz de causar pequeninas agonias seja em quem fôr. Tenho um genio doce, zango-me muitissimo poucas vêzes e só depois de me têr enchido de razão. Vejo a felicidade no socêgo, na monotonia da vida exterior e na riquêza da vida interior e contemplativa.

Herdei do meu pae simplesmente o amor à serenidade, a independência, o desprêzo das commodidades. Elle nunca chamava um criado, e eu nunca chamo. Em qualquer cama dormia, em qualquer sítio almoçava: sou assim também. Mas elle foi, o que não sou, um homem essencialmente de acção: teve uma mocidade de cavalleiro combativo. Eu herdei da minha mãe o mais íntimo do meu temperamento: a susceptibilidade profunda, a sensibilidade feminina de artista. O França completa-me: é-me tão superior na acção quanto eu lhe sou em intelligencia.

Sou pois um homem de pensamento, um intellectual e um contemplativo. Custa-me immenso o ferir alguém. Os meus mais fundos sentimentos são os da piedade, da commiseração. Pequenas coisas me podem fazêr na alma uma resonância enorme, arrastando-me então ao cairel de um precipício; mas nunca os desgostos me levaram a sêr duro com as pessoas, mesmo as mais íntimas, diffícil de aturar ou impaciente com ellas. Tenho sempre, sempre, o senso da justiça. A minha serenidade resulta pois de um cuidado constante em me equilibrar, e não de que seja de natureza fundamentalmente descuidôso, confiado e risonho.

A minha intelligencia distingue-se pela lucidêz, pelo amôr das ideas claras, claramente ennunciadas. Mais nitidêz pois do que imaginação. Tenho uma grande tendencia a achar o lado verdadeiro de qualquer opinião, mesmo das que me contradizem. Não sou nada fanático, sectário, magister dixit, mas pelo contrário mantenho-me sempre aberto a tudo num espirito de duvida e de interrogação. Para a acção é isto mau, para a justêza é bom.

Tenho um grande amôr mistico pelas coisas puras, e sou christão em certa repugnancia instinctiva ao que às vêzes se chama a naturêza, quero dizêr à vida considerada por um criterio exclusivamente pagão e naturalista, mesmo no sentido nobre das palavras. Este 
misticismo é exclusivamente sentimental, não intellectual. Pela cabêça sou um atheu completo, mas não um negadôr; irreligioso, mas nunca antireligiôso.

Ai, meu bem, dirá que me deixei arrastar a bem prosaicos dizêres! Mas ao menos confesse que o retrato está justo, que me não lisonjeio a mim próprio e que me conheço suficientemente. Para a indemnizar, vou vêr se consigo escrevêr-lhe alguns versos no mesmo metro dos francêses que me mandou. Ora tentemos. Ria-se d'elles, mas não de mim. Supponhamos uma serenata, um noctívago embuçado, co'a guitarra do Almaviva. Um balcão, algum folhềdo rumorejante. Com ou sem lua, à vontade do frèguếz. O noctámbulo ergue o pescoço, aguça a voz, e canta:

Ó mágica açucena,

Não sei que hei-de entoar

Na sonorosa avena;

A terra, a selva, o mar,

Segredam sobre ti

Murmúrios de encantar...

A viração sorri

De lhe eu, se me desperta,

Dizêr: «não sei, não vi...»»

- «Ó doidivana, àlerta!

Não vês a madrugada

Já no horizonte aberta?»

Vem sobre a luz doirada

A festival Manhan;

Pergunta-me, inclinada:

Que te contou a fada

Da noite embalsamada?

— «Sonhei co'a tua irman...»

E a verdade é que sonhei consigo, meu amor, toda esta noite, e a vi deslizar não sei porque meandros floridos...

A.

Minha pomba:

[31-5-09]

Muita e muita e muita alegria me deu. É escusado dizer-lhe que acertou nas suas supposições. A Pilar não está em casa. A minha mãe abriu a carta para ella e encarregou-me de lhe mandar as musicas. Não sei se serão só essas. Não encontrei outras. Não posso alongar-me por motivos que comprehenderá. Adeus, minha joia, minha noiva, minha irman, um milhão de saudades do muito seu

A. 
Luisa:

[31-5-09]

Aproveito a occasião de a minha mãe lhe mandar uma capa para lhe dizêr duas palavras mais. Sinto, minha rosa cândida, uma doçura enorme fluir, espalhar-se, effundir-se dentro em mim; tenho cá dentro o mesmo fulgor acariciante d'este sol estivo que nos alumia. Pudesse o meu alento corrêr ao pé de si como a agua de um regato, pudesse mettê-la no meu peito como um perfume imarcescível, pudesse cada carta minha mudar-se em flor na sua mão! Ponha toda a sua vontade em querêr realizar um amor exemplar, perfeito, sem uma mancha, uma sombra, uma quebra. Quaesquer que sejam os acontecimentos, brutaes ou inevitáveis, quaesquer que sejam os factos que a fatalidade das coisas nos trouxer, que as ideas e os sentimentos sejam sempre superiores, constantes, eternamente affirmativos da limpidêz das nossas almas: "Deixa os teus olhos tornarse em luz!" Sejam as nossa almas cada vêz mais claras!

Mostre-me constantemente que está alegre, diga-me constantemente que é feliz!

Espero por quinta feira como pela entrada num paraíso. Amanhan, quando entrar no quartel já lá deve estar a sua carta. Não lhe peço para falar ao telefone, sabe porquê: mas pode calcular quanto a coisa em si me seria agradável. Em todo caso, seremos curtos e um tanto cerimoniosos... Ou às nove da noite de amanhan, ou às dez $\mathrm{e}$ meia do dia seguinte... ou em ambas as occasiốes, minha Luisa muito amada, a quem mando tantas, tantas, tantas saudades!

Um aperto de mão do seu irmãosinho

António

Não gostei nada da tarde de hoje, meu amôr. A costureira, os trapos, tanta coisa, tudo me seccou a alma. Dá-me vontade de a ir lá buscar, trazê-la de novo para o pé de mim. Quanto melhor seria se estivessemos só com a Pilar! Não a senti minha. Escreva-me uma bôa carta para o quartel, a dizêr-me muitas coisas doces, muito meiga, ouviu? 
4 à tardinha

[4-6-09]

Minha Luisa:

Recebi a sua cartinha, e não lhe respondi no quartel porque o serviço m'o impediu, e porque tinha que fazêr cá fóra. Vou agora jantar e depois fazêr um pouco de companhia ao Frederico, que está doente de cama. Mande-me a tal carta «massuda» e diga-me porque estava abatida como me contou na de hoje. Espero recebêr e respondêr espaçadamente amanhan.

Muitas saudades do seu

Antonio Sergio

Sabbado, no Quartel, 9 da noite.

[5-6-09]

Venho continuar a conversa do telefone. Fiquei cuidadoso de me não têr chegado ainda a sua carta. De manhan, ao entrar, alem do desapontamento que calcula, fiquei com receio de que lhe tivesse sobrevindo alguma coisa má, doença, desgosto, desalento, fosse o que fosse. Não que tencione medir o seu amôr pelo comprimento ou pelas amabilidades das suas cartas: mas uma falta assim tão sem esperar ha-de convir que é para dar preoccupações. Uma palavrinha só, mas boa, deixar-me-ia sem cuidados, - e sem exigencias. Não quero que se esforce: escreva quanto, como e quando lhe appetecêr.

Explique-me que exaggeros temeu que eu achasse na sua carta. Se effectivamente houve exaggêro sou o primeiro a lamentar, porque nesse caso não me estima tanto quanto me diz — o que, valha a verdade, não é muito consolador...

Minha Luisa: - Minha!... Não penso no futuro sem o vêr fechado, mas não lhe falo nisso porque lhe desagrada, - sobretudo porque interpreta mal. A minha situação é mais impossível que a de qualquer outro, porque nem posso contar com o tempo: grão a grão... Os meus encargos de família varrem tudo, como o vento de outomno dispersa as folhas. Se me saisse um milagre de um alçapão, como nas mágicas, era questão para oito dias... Minha Luch, coitada, em que situação se foi mettêr! Já deve estar convencida de que se lhe digo isto não é porque me pese ou desagrade a nossa situação actual, como em tempos escreveu: por isso me atrevo a aflorar o assumpto. Chego a têr vergonha do que estou fazendo, sem têr a durêza de cumprir o que seria talvêz o meu devêr: sacrificar o meu amôr e sacrificar o seu. Minha Luisa, minha Luisa, isto não a deve preoccupar, porque estou só falando e mais nada, expondo o que me passa pela cabeça, sem que tencione pôr nada em prática: deixarei corrêr as coisas como vão, na delicia de me suppôr amado e de lhe repetir que lhe quero muito... 
Oiça, minha pomba: tem-me muito amor, muito, e muito convicto, lá de dentro, muito paciente, sem um só momento de interrupção, sem um unico desfallecimento? Desde quando? Já ha muito me tinha em melhor conta que todos os outros, ou chegou a julgar alguém tão bem como me julgou a mim? Terá a sua bondade a persistencia de ser sempre, e apesar de tudo, a grande consoladora a que me vá dessedentar de todas as sêdes, convalescêr de todas as febres? Veja lá, não venha a desilludir-me e a desfallecer um dia. Não me julgue melhor nem peor do que sou, e diga os defeitos que me encontra, para tentar libertar-me d'elles. Ai que maçador que eu estou, minha Luchezinha! Em idea, de cá de longe, beija-lhe respeitosamente as mãos o seu

\section{Antonio Sergio}

P. S. Escreva-me, mas está dispensada de respondêr às reflexões e às perguntas d'esta carta.

Segunda-feira, 7-6-09

Não estava triste, minha querida Luisa, mas bastante aborrecido por lhe não podêr falar à vontade e pela atmosfera de curiosidade e desconfiança que ali havia. A prima $R u$ ch anda muito magoada commigo, e censura-me já com certa acrimonia, - censuras que acatarei sempre humilimamente, por virem de quem veem. Faça o que fizer, ser-me-á sempre sagrada, tanto mais que a encontrei sempre bastante nobre. Não lhe posso levar a mal que se sinta cheia de razão contra mim, porque ella não sabe o que se passou no meu íntimo com relação a ella, porque não seria capaz de comprehendêr a extravagância dos meus sentimentos e do meu genio. Mal entendidos a que estão sujeitos os bichos muito originaes, exóticos, eștrambóticos, desvairados, etc., etc., como este seu criado e amador. E claro que nunca desci à baixêza de me justificar fosse com quem fosse, nem com ella, nem com outros. Fui sempre mudo como uma estátua. São coisas de que só falaria à minha Luch (se a minha Luch o exigisse) e por sêr a minha Luch. Haveria o perigo de suppôr que arranjava os factos segundo os meus sentimentos e conveniências de hoje. É pecha de todos. Acreditaria o meu amor que eu fazia excepção? Com as cartas que por essa época escrevi (não as tenho em meu podêr) e uma leitura perspicaz da sua apertada fraseología, demonstrar-lhe-ia à evidência a realidade. $E$ tenho esta convicção: se soubesse como eu intimamente procedi com ella, haveria de approvar altamente (pelo menos apreciar) a conducía do seu Antonio Sergio. Ha-de julgar-me muito vaidoso, não é verdade? Pois não o sou. Nada d'isto é vaidade, mas só mania de bem fazêr, e de me mostrar muito digno de todo o amor que me possa têr. Voltando à prima Ruth, sou bem amigo d'ella, tenho motivos de a respeitar e admirar muitíssimo, e é por ella que lamento que se tenha agora obscurecido um pouco a ponto de dizêr a alguém as censuras à minha pessoa que julga merecidas [

Mudando de assumpto: não é da opinião de que as confidencias às amigas são uma enorme projonação, reveladoras de uma grande 
superficialidade de sentimento? Em mim, pelo menos, os sentimentos profundos são occultos, noctivagos, arrecadados como as coisas sagradas, guardados como os misterios divinos. Diga-me o que pensa. A sua carta "massuda" só responderei se assim mandar. Adeus, minha Luisinha, aperto-lhe as mãos com muita alma. Quando lhe poderei falar finalmente, o que se chama falar? Esperarei com paciência. Faça um exame de consciência bem sincero, veja se me ama muito, muito, muito e mande-me o resultado. Seu

\section{Antonio Sergio.}

P. S. Percorra a Historia da lit. francisa do René Doumic, para depois entrar no Marañal do Brunetière.

[9-6-09]

Minha Luisinha muito amada (e muito amante?...):

Caiu-me um auto muito complicado que me deu hoje muito que fazêr e que terei de continuar amanhan. A sua visita anda mal afortunada: oxalá se não tivesse decidido por amanhan, porque terá de addiar novamente. Espero que me falará logo à noite pelo telefone, e então combinaremos. Estou maçadissimo de ouvir testemunhas, testemunhas, testemunhas, crime, revolver, accusações, delinquentes, uf!

Gostei muito das suas observações. Algumas revelam muita justêza e attenção, o defeito das outras provém quasi sempre da falta de hábito.

«Comment peut-on ne pas aimer toujours ce qu'on a aimé une fois?». Parece-lhe havêr uma contradicção em relação a esta frase, quando não ha. Nunca peguei num trecho sem reparar nos que o acompanham. "Il ne comprend pas Voubli..." Foi mesmo o meu amor que copiou isto duas linhas antes. Hamlet deixaria talvez de amar, mas tinha razões para tal, não foi por esquècimento. $A$ pergunta do principe é esta: «como se pode, simplesmente por esquecimento, deixar de amar a criatura que todas as razões nos fazem estimar?» o caso da Rainha em relação ao pae Hamlet, homem superior e que a mulher esquece (Hamlet não sabe ainda toda a hediondez do caso) para casar immediatamente com o cunhado, um surrelfa [?] (Scena 2. a, me parece, conversa com os reis e monólogo de Hamlet sobre a differença dos dois maridos e a rapidêz do casamento). $O$ amor de Hamlet pela verdade é admirável, raríssimo $e$ muito significativo da época (Renascença) porque tem um alcance muito maior que o caso que constitue a tragedia. Lembre-se como elle se emprega todo em desmascarar os motivos de todas as acçôes; a ironia prespicaz com que vê, examina, desdobra, vira do avêsso e acaba por esmagar os cortezãos! Repare na amizade por Horacio. Veja como nunca, nunca perde a cabeça, e esquece designios, projectos, acçÔes, sentimentos, para examinar, conhecêr como a naturêza é no fundo e as almas são por dentro. D'ahi o estimar só os homens que, como Horacio, «não são escravos das suas paixões», quer dizêr, nunca cegam, não deixam 
passar nenhuma mentira pela peneira da reflexão. D'ahi, $\wedge$ ainda, o sêr tão severo para si próprio. É preciso começar por se sêr implacavelmente verdadeiro comsigo mesmo. A minha Luisa não percebe esta frase. Faz-me pena que a não perceba. Não vê como todos os homens se lisonjeiam, e se enganam a si próprios, attribuindo sinceramente às suas acções causas muito differentes e mais bellas que as verdadeiras? Julgamos o proximo segundo as nossas paixões e sentimentos, e não segundo o nosso juizo. $O$ juiz que trazemos dentro, somos os primeiros a corrompê-lo. Passamos a enganar-nos a todas as horas, a propósito de todos os actos. E a minha pombinha terá de se exercitar neste ponto, porque ainda talvêz se illude $^{\wedge}$ bastante $^{\circ}$ a si mesma. Não admira nada: a virtude da veracidade íntima, a mais rara de todas, é essencialmente masculina, não feminina.

Já comprehendeu por força o que são «les mensonges du coeur». Noventa e nove por cento das mentiras graves são do "coração». Como para seguir as suas paixões os homens atabafam, assassinam a consciência à força de sofismar! como os amantes se mentem um ao outro! como as intenções mais vis se mascaram de amor elevado e nobre! como quasi todos os amores veem a naufragar num rocal de mentiras!

Vamos à scena com Ophelia. Hamlet amava a mãe, suppunha-a alta e pura como elle o era. Quando veio a sabêr a verdade, muito natural e justamente passou uma condemnação absoluta à apparência feminina. Note ainda que Ophelia, não tendo carácter próprio, é fraca, amolda-se a tudo: não merece confiança. Será digna se dér com um homem digno, mas deixar-se-a cair na objeç̧ão se der com um biltre. É o que Hamlet, entre muitas outras coisas, lhe dá a entendêr. Mesmo falando geralmente, a mulher vulgar é criatura irracional, impulsiva, deixando-se arrastar pela emoção do momento a escolhas de fazêr blasfemar o mais scéptico. Não ha nada tão amargamente doloroso como isto - o sarcasmo, a blasfémia, a retaliacão de nós mesmos a surgir de vêz em quando do pensamènto sobre uma mulher de quem se gosta. Ai dos homens que, como Hamlet, não podem cegar completamente! $\mathrm{Ai}$ dos que não esquecem, ai dos que são exigentes, ai dos que desconfiam! Uma criatura que quereriamos vêr alta (como Hamlet à Rainha) ama um palhaco torpíssimo, como esse nojento Rei de que o pobre via toda a baixêza ${ }^{\wedge}$ toda a sordidêz, ao mesmo tempo um bandido e um histrião. Então há como uma nódoa que alastra, e tudo nos apparece diluído e viciado. Os que não acreditam em Deus teem o unico recurso de só confiar plenamente no ideal imaginativo que dentro de si trazem, e de se elevarem pelo isolamento...

Le jour n'est pas plus pur que le fond de mon coeur...

Hamlet a fort raison de l'aimer, car si elle devenait sa femme, elle serait capable d'un inaltérable dévouement, précisément par ce pui lui manque d'élévation». Commentario seu: «então só as almas sem elevação são capazes de dedicação completa?». Isto, minha Luch, é um êrro de análise grammatical. O Momtégut não diz que só as almas sem elevação são capazes, etc. Se por acaso ouvisse dizêr: "Fulano disse a verdade, ou confessou o crime, precisamente porque estava embriagado", não concluia naturalmente que só dizem a verdade os homens embriagados, ou só esses confessam os seus crimes, mas sim deveria concluir que entre as muitas razões que fazem às veses dizêr a verdade, uma d'ellas (e a peor) é a embriaguêz. Applicando al cuento: uma das razões (e a peor) porque às vezes certas mulheres se tomam de forte apêgo a um homem, é a sua inércia de alma, a sua fraquêza, a limitação do seu horizonte. São umas pobresinhas 
que nascem como uma flor à mercê de todos os ventos, que não teem em si força para resistir a coisa alguma, nem cabeça para julgar por si mesmas. Foram fadadas para escravas, para se diluirem e perderem na vontade do seu senhor, quer esse senhor seja bom ou mau, grande ou pequeno, virtuoso ou baixo. Agarram-se muito agarradinhas ao tronco de uma árvore, não porque percebam a bellêza da árvore, mas porque coitadinhas precisam de se appoiar a alguma coisa, à coisa que lhes apparecer a leva-las por esta vida, a defendê-las das rajadas... «Eu sou aquella que admira, obedece, não pensa e está», diz uma personagem de não me lembro que novella. São boas ou más, comforme o senhor:-pois se ellas não escolheram... Veja a Ophelia, pobresinha: à primeira desgraça enlouqueceu, - e que louca tão meiga, tão submissa, tão infantil. Canta muito innocente uma cantiga que o não é muito, distribue algumas flores, e morre. Affeiçoam-se às pessoas como um cãosinho: mas são agarradinhas e fieis como o cão é.

Acostume-se a minha Lueh a sêr poeta, a entrar nos sentimentos e nos caracteres, a sentir a riqueza, a variedade, a complicação das coisas. Fique sabendo que o mesmo resultado, o mesmo sentimento, o mesmo acto, se pode obtêr diversamente com causas muito diversas. Ophelia era dedicada a Hamlet, Julietta a Romeo, Desdemona a Otello, George Sand a Musset («je fai aimé comme un fils!») e até a Severa ao Conde de Vimioso, - e corn motivos muito diversos, em virtude de sentimentos, de ideas, de caracteres muito diversos.

Então queria que o Hamlet, depois de matar o Rei, o Polonio, c Laerte, os dois embaixadores, não fizesse sabêr a verdade e a justiça, illibando-se a si e ao pobre Laerte (que desceu à infamia das espadas seduzido pelas mentiras do Rei)? $\mathrm{E}$ porquê? Por causa da Rainha? Enquanto ella vivia, e vivia o Hamlet, percebe-se o escrúpulo d'este, para não sêr matricida e não publicar uma vergonha que roçava por elle. Mas mortos os dois? Salvar à custa da sua a memoria de uma vibora e de um bandido que lhe tinham morto o pae (que continuaria in ulto)? Ha-de concordar que seria uma sublimidade irracional, injusta, absolutamente falta de criterio, indigna portanto do justo, do verdadeiro Hamlet. Era preciso além d'isso que a glória posthuma do Hamlet honrasse e premiasse o seu único grande affecto e o seu único grande amigo: o digníssimo, pobre, obscuro, dedicado Horacio.

Repito-lhe que gostei muito da sua carta. Apesar de lhe não achar razão, as observações que apresenta são finas, interessantes, intelligentemente apresentadas. $O$ facto de têr achado objecções a fazêr ao Montégut (que nem sempre se exprime com muito rigor) já de si revela independencia e agudeza de critério. Seja sempre absolutamente franca nas suas opiniốes, não deixe passar coisa alguma. Espero as notas sobre o Misanthropo.

Hontem examinei alguns problemas interessantes e compuz uma peçasinha de um cento e meio de versos que talvez mande para o Brazil-Portugal. Apesar de muito esvaido pela insonnia, e de pensar muito em si, chega-me o tempo para a cabeça continuar a cumprir o seu devêr. As minhas duas grandes consolações são a estima dos que me amam e o vigor do intellecto: oxalá me não traiam nunca! Até hoje tenho-me embrenhado em estudos de que o meu amôr não poderia fazêr idea alguma. Vou-lh'os sacrificar quanto m'o permitte a minha curiosidade, e escolhêr outros que a minha Luch possa seguir mais ou menos e comprehendêr, para que seja minha companheira em tudo. Espero que esta decisão lhe dê bastante alegria. As pessoas não se unem verdadeiramente pelo facto de morarem na 
mesma casa e comerem o mesmo jantar. Adeus, cheguei ao ultimo momento. Tenho de mandar esta já. Ame muito e muito o seu

Antonio Sergio

Quártel, 9 de Junho, (09) 9 da noite, ou pouco mais.

Disse-me a menina da estação que interrompera porque queriam ligar para si. Lembrei-me de que seria seu Pae que teria pressa de lhe falar e por isso pedisse para interromperem. Oxalá não tenha tido algum contratempo.

Vamos ao retrato. Lembra-se da primeira vêz que a vi depois da sua ultima ida ao extrangeiro? Foi de noite, em sua casa. Appareceu-nos de risca ao meio, uma dobrazinha para cima de cada lado e atrás uma fita negra de uma banda à outra., Quereria uma assim. Para escolher, tire uma das provas de frente. É como em geral vejo as pessoas quando as evoco, a olhar para mim. Mas escusa de se incommodar com pressas, porque este provisoriamente satisfaz-me.

Quanto às perguntas da sua carta para que pede resposta, tenho a dizê-lhe muita coisa. Desde a primeira occasião em que nos juntámos nos Vargos me teria attrahido completamente a si se não fosse o aspecto muito artificial da sua maneira de falar de então, onde julguei descobrir uma sensibilidade nada verdadeira, uma educação de sentimentos muito falsa e ainda uma esfriadôra camada de vaidade. Perdoe, mas foi assim que me appareceu. Nunca pude acreditar nos sentimentos que não teem o horror das frases convencionaas. Como prova, peço-lhe que releia o prólogo que escreveu no Momento no Paraíso. Qual é a sua opinião, hoje, a respeito d'aquella página de rhetórica? Se a Luisa me fôsse completamente indifferente não ligaria importancia nenhuma ao caso. Divertir-me-ia observando-a, como num espectáculo. Não succedeu assim: fez-me pena e acrimonia. Para comprehendêr bem, dêvo dizer-lhe que eu passava então a primeira crise da minha vida. Ia feridissimo, doente d'alma até ao fundo, sensivel e delicado como uma pétala. Acabáva o primeiro anno da Escola Naval com uma grande desillusão. Percebi que a minha carreira me não poderia dar nada do que esperára d'ella. Era uma vida completamente cortada. Atraiam-me a arte e a especulação, que via completamente incompatíveis com a vida marítima. O meu Pae (único recurso nessa época) não comprehendeu a minha lucta, e em vêz de entrar em mim, de me consolar, de me dirigir, atacou-me. Ninguem que conhecêsse o meu íntimo, que sus-

peitasse das ideas que me encantavam, que se interessasse pelo que me interessava! Dos amigos do Collegio Militar tinha-me separado inteiramente, porque nenhum viera para marinha. Do Collegio e da Politechnica vinha acostumado a que os professores me enchessem de homenagens, impondo-me a admiração dos condiscipulos. Lembro-me ainda que depois do meu exame de matemática na Politechnica todos que tinham sido do collegio me fizeram uma manifestação como uma gloria para elles. Por esse tempo, nem reparava nisso, porque nunca fui nada vaidoso, - mas depois, na Naval, que queda! Os professores eram uns burros enfatuados e oquíssimos, de quem todos troçavam, que me não inspiravam senão desdem. Quando um homem 
na situação d'elles se não pode impor pelo mérito recorre à pose. Foi o que fizeram, - e vi os asnos a pavonearem-se commigo, depois de homens distinctissimos me encherem de respeitos! Desdenhavam dos meus estudos. Filosofias! que diacho era isso? Um qualquer chamou-me «espirito empedernido pelo abuso das matemáticas», "coração dissecado pelo excesso da análise»; alguns, enfatuadamente paternaes, tinham sobrancerias protectoras; - e eu temendo que fosse sempre assim, pela carreira fóra, com todos os meus superiores!

A prima Ruth, que julgo soubéra alguma coisa pela Mathilde (que assistiu às minhas tristes scenas com o meu pae) a prima Ruth, levada pela admirável bondade do seu coração, falou-me, ouviu-me, pareceu-me comprehendor. Até que emfim! Encontráva o ouvido, o coração, o confidente que me recebesse!-por isso ella foi, e ficará para sempre, uma personagem de primeira importancia no desenvolvimento da minha pessoa moral. Direi mesmo a de maior e incomparável importância: a minha historia interior, sem ella, seria completamente incomprehensivel. Tinha finalmente o amigo necessário (só mais tarde atrahi seriamente o França, que se educou depois com facilidade ao meu modo de sêr). Passado algum tempo comprehendi que a amizade entre um homem e uma mulher se não póde sustentar. A nossa affeição comprommette-a, empata-a, faz nascêr uma atmosfera absolutamente instável. Fiquei surprehendido: nunca pensára em amor, em mulheres, em casamento. A vida fóra para mim até ahi um jogo de imaginação puramente desinteressada e não-sentimental: lia muito história, saboreava a matemática, era no collegio muito vivo, revolucionário, excêntrico; deixei lenda. Os officiaes reprehendiam-me muito, e castigavam-me pouco por sêr o estudante que fui. Era sublimemente idealista, ingénuo e puro, absolutamente alheio a todas as realidades da vida. Não as via, por só sêr intellectualista; nem mesmo até lhes sabia da existência, por vivêr na abstracção. Como passava sem dar pelos homens, e como não tinha em mim paixões, não pensava na superioridade moral, por não conhecêr a inferioridade moral. Para mim, a única superioridade era a da intelligencia: considerava as pessoas intelligentes e sabedoras; as outras não existiam. As mulheres eram umas nuvens, saias, blusas e chapéus. Fiquei impressionadíssimo quando um dia, com 19 annos, descobri que por dentro d'esse vestido havia um corpo, por dentro d'esse corpo um coração. Tinha-as na conta de pouco intelligentes, ignorantes, e como tal não lhes dava importanda.

A Luisa chamou-me a attenção por muitos motivos. Mas considerei-a como a uma obra d'arte, uma estátua de marfim, uma flor, um poema, de que gostaria de me approximar, tão candida e innocentemente como uma criancinha, - que eu na realidade era, uma criancinha intelectualista e devaneadôra As suas maneiras repeliram-me; desgostou-me; culpei-a de a não encontrar como eu queria...

Como lhe disse, fiquei surprehendido nas minhas relaçóes com a prima Ruth. Tinha-lhe uma amizade terna, muito grata, respeitosa, mas nunca me passara pela idea que uma mulher me pudesse amar, nem mesmo julgava isso possivel. Era nesse ponto infinitamente modesto, talvêz à força de sêr criança. Acaso the teria amor, mas eu não tinha consciencia d'isso. Respeitava-a e estimava-a muitissimo, era-lhe sobretudo muito muito e muito grato. Percebi em breve a falsidade da nossa situação; falava-se; convenceram-me de que as coisas eram outras do que eu supposéra. O que eu sentia seria uma paixão amorosa, pura e simplesmente uma paixão amorosa? Não, com certêza, posso jurá-lo firmemente, e sempre o disse a mim mesmo e a alguém mais. Entre os meus sentimentos têr-se-ia insinuado um 
veiosinho de paixão amorosa, mais ou menos inconsciente? Só sei dizêr que é impossivel levar a esse ponto o esmiuçamento, o destrinçamento de um sentimento complexo como era o meu. Não digo redondamente que não nó por médo de errar. Sei ainda que vinha da Escola, tinha ao jantar questões terriveis com o meu Pae (em que chorava) e ia tomar ar para a rua e consolar-me em S. Paulo. Encontrava lá urna amiga, a unica que levava a sério as minhas aspirações, a unica que comprehendia o meu horror à Escola, a única que eu suppunha convicta da minha superioridade. Bemdita seja ella, que não calcula quanto é ainda o meu remorso e a minha gratidão! Mas como convencê-la agora d'esta minha gratidão, passado o que se passou depois?

Emfim, caindo na realidade, depois da primeira surprêza percebi que a minha situação de amigo íntimo de uma rapariga era mundanamente insustentável, e chegadas as coisas ao pé em que estavam julguei meu devêr declarar-me. Disse-o à Mathilde. Ella admirou-se; «nunca ninguém julgará seu devêr uma coisa tal; ninguem eomprehenderia tal sentimento; jamais um homem assim procedêra». Lembro-me de que lhe respondi.

- Não quero sabêr do que fazem os homens; eu, se pudesse sêr um deus, - era-o. Ella chorou, e deu-me um grande beijo

Agora, finalmente, já posso respondếr às suas perguntas. Desde quando a estimo? Desde 1901, nos Vargos (ou 902, não me lembro bem do anno). A sua maneira de se apresentar e a simpatia d'outra pessoa vieram porem affastar-me de si, affastamento que a sua «malfadada loucura» levou ao maximo. Nunca porem me esqueci da sua pessoa (poderia demonstra-lo por cartas de Macau à Mathilde, etc.). Tornou a interessar-me vivamente ao voltar agora de Cabo-Verde, - principalmente desde o dia em que, tendo eu deixado de ir a uma soireé em sua casa por andar atormentado, appareceu na minha a sabêr de mim. Lembra-se? Sentou-se no sofá da sala, eu à sua esquerda na cadeira da India, a Pilar ao pé de mim, defronte de si a Miss; levava um chapéu de abas brancas. Depois veio o mês de Agosto nos Vargos, de que nunca mais nos esquecceremos, não é verdade? Ah minha Luch, minha Luch, que deliciosas noites aquellas, meu amôr, que danças, que cantos, que alegria! Que tristeza a retirada, e como eu a esperei no dia dos meus annos! Foi logo pela manhan o bilhetinho:

Sobre vós, bois d'olhar manso, Que branda que a noite vem!...

«À Illusão» foi feita nos Vargos, mas escondi-o, porque me tinha servido de modêlo para a descripção.

Imagem formosíssima e celeste...

Bemdita sejas...

Comecei depois a suspeitar de que também me amaria, mas resolvi evita-la pela minha situação. Ora um dia, como sabe, as boas tenções periclitaram [............]

Lembre-se todos os dias d'este período da sua ultima carta: «um amôr que queremos chegue ao máximo a que se pode chegar neste mundo». Prometta-me que será essa a sua constante preocupação. Que o amôr mais completo esteja sempre presente nos mais pequenos actos, em todos, todos os momentos. Só temos uma vida a vivêr cá na terra: não basta esta idea para que procure- 
mos desde já fazê-la o mais alta que pudermos realizando uma affeição muito bella, muito bella? [

Deixe-me olhar para o seu retrato, preciso de me esquecer, refugiar-me nalgumas ideas.

Contemplando o fulgor da pura Idea

Tu' alma entoará soberbos hinos

Â belleza immortal que a senhorea!

Não tenho, talvez, frase mais «Sergiana» do que esta.

Será pueril, mas estou em cuidado no caso do telefone. Oxalá não succedesse nada de mau. Não me atrevo a pedir communicação para sabêr, porque tenho mêdo que saia asneira, tenha visitas em casa, etc. A proposito, confesso-lhe que me custa ás vezes lembrar-me de que lhe escrevo sem auctorização do seu Pae. Mas que havemos nós de fazêr? É tanta pena que as circunstancias nem sempre nos permittam a conducta ideal!

Porque será que fica nos retratos com uns contornos duros?

(Agora interrompi porque me chamaram para o telefone. Era a minha Luch. Fez bem, como vê pelo que disse nas linhas acima).

Tomara já o retrato de frente (ou quasi) e de bandos. Oxalá fique bom. Se a prova a $3 / 4$ ficar melhor, escolha essa. Seja a seu gosto. Hoje mesmo mandei tirar reprodução do meu.

Pensa muito bem sobre as confidencias. Se alguma vêz fosse preciso recorrêr a alguém para nos prestar qualquer serviço de força maior, seria preferivel metter no nosso segrêdo o França a qualquer outra pessoa, homem ou mulher, por sêr a unica criatura para mim de segrêdo absoluto, confiança absoluta e discreção absoluta. Se alguma vêz pois fôr necessário, já sabe que é d'elle que lançarei mão, e não tenha repugnancia, porque é d'aquelles em quem sabe bem a gente confiar as suas coisas.

Minha Luch, espero que esta carta a não apoquente porque nada tem de apoquentadôra. Se lhe disse o que disse foi para confessar tudo, como deve sêr entre nós: transparência perfeita.

Luisa, «vida, doçura e esperança minha»: não leve a mal que empregue as frases da oração; amo-a muito, amo-a muito bem, tinha vontade de a apertar tanto contra o coração que a mettesse dentro do meu peito. Penso em si, vejo-a estando ausente, beijo-lhe fervorosamente as mãos

\section{Antonio Sergio}

Minha Luisa

Quartel, 10 da noite. [12-6-09]

Foi preciso ouvir a sua voz para que acalmasse, e bastante, da desgraçada impressão que me fez a sua carta. Acabo de lhe falar ao telefone para lhe dizêr que estou melhor; não que me tivesse conformado com as suas extraordinaríssimas palavras, mas porque vou conseguindo deixar de pensar nellas. Essas palavras, a maneira como afastou conselhos, avisos, etc., pelo J. Machado, dão-me a impressão de que elle foi para si mais do que o que eu jamais serei. 


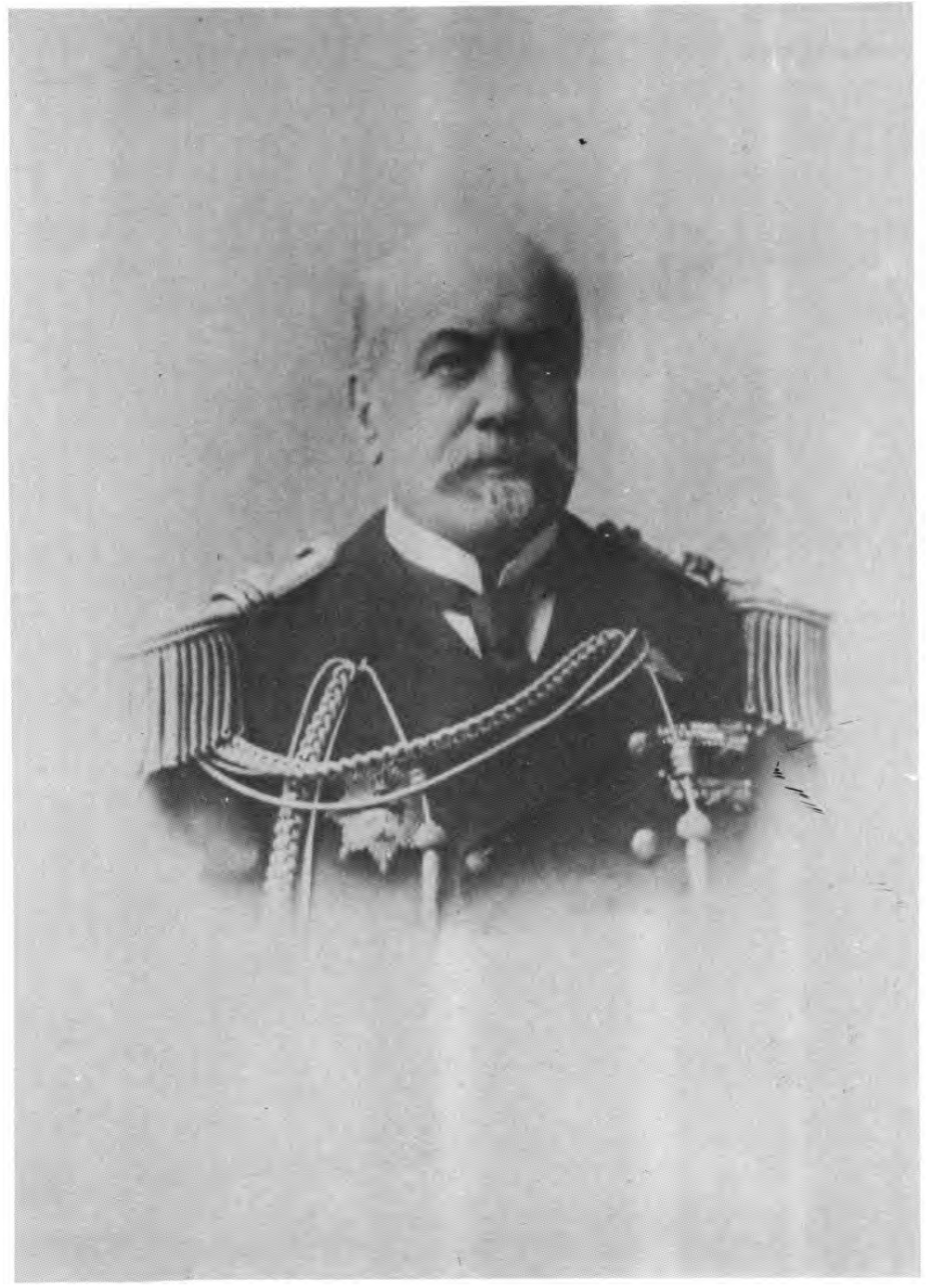

Almirante Antonio Sérgio de Sousa, pai de António Sérgio 
(Página deixada propositadamente em branco) 
Para remate li que guarda, respeitada, a lembrança d'elle no coração. Fazendo d'elle um heroe sublime, accusa-me a mim de mentir. Eu, Luisinha, não me sentiria bem com elle na mesma casa, quanto mais no mesmo coração [.......... Feliz d'elle, feliz d'elle, que conseguiu sem esforço algum o que jamais conseguirei depois de annos de uma existência votada toda ao amor das ideas santas. Só os homens veem os homens sem máscara: só os homens me fazem justiça, e desconfio que só já d'elles a posso esperar. Oiça, Luisa, uma coisa que bem pouca gente lhe poderia dizêr: se lhe fosse possivel seguir a minha vida acto a acto, pensamento a pensamento, todos os minutos, não encontraria uma só coisa que eu tivesse de esconder, nada, nada. Mas isto é tolo, e não vem a propósito; ou por outra vem, para lhe dizer isto: eu não merecia, Luisa, que me desse o desgosto que me acaba de dar.

Mando a carta que lhe escrevi de dia. Não se apoquente, o tempo fechará a chaga. Vou ver se descanso um pouco, porque estou quasi a cair. São 11 horas: não descansarei nada. Adeus. Muitas, muitas, muitas saudades do seu.

\section{António Sérgio}

Minha Luch:

Mandei o homem embora antes de lêr a sua carta, e fiquei com muita pena de não mandar ao meu amôr a resposta que me pedia. Vou fazêr talvez asneira escrevendo-lhe agora, mas não quero que continue apoquentada emquanto o seu Antonio Sergio está já tão completamente pacificado e satisfeito.

Minha Luisinha muito amada, perdôe-me têr-lhe feito mal, mas não podia deixar de assim sêr, aliás não ligaria importancia a palavras graves que disse sem bem medir o que dizia. A minha Luch pensou e sentiu bem, mas escreveu mal. Está tudo explicado, e não se pensa mais nisso.

Quando verei eu a minha pomba, quando a verei eu! Gostaria que me visse, para verificar que já não ha sombras no meu gesto. Tenho a impressão de uma alvorada que murmura depois de uma noite muito feia. Minha noiva muito querida, já posso hoje adormecêr sorrindo e a pensar em si, e acordar logo amanhan da mesma forma, como se não houvesse interrupção. Esteja muito alegre, muito alegre, muito alegre e seja absolutamente transparente com o seu muito amante e respeitosíssimo

\section{Antonio Sergio}

P. S. Vou amanhan de manhan ao Quartel, e estou de serviço depois de amanhan. Escreva portanto hoje e amanhan. 
Minha Luisa:

Acompanhei, com a Pilar, de casa do França à Avenida Ressano Garcia a D. Elisa e a D. Valentina Pinheiro Chagas; e agora (meia-noite) ao chegar a casa, não quiz deixar de escrevêr duas palavras para o meu amôr recebêr amanhan pela manhan. Espero que estará contente e já refeita do mau bocado que passámos; e amanhan, se vir pela sua cartinha que já está perfeitamente calma, poderei responder ao que me disse na que hoje recebi. «Meu Sergio, que eu amo tanto, tanto!»: - ficou-me esta frase a tlintar cá dentro, e espero que m'a repita de quando em quando. Minha Luisa, pensei muito em si durante a noite, com muita vontade de a acariciar. Teria vontade de lhe escrevêr mais, mas preciso de sair para pôr esta no correio. Lembre-se sempre do seu Antonio Sergio, e diga lá muito para si que o ama, e que elle a ama. Convença-se de que, neste transe tão mau, não foi a minha noivasinha quem soffreu mais. Beija-lhe com muito amôr as mãos o seu marido muito respeitoso

\section{Antonio Sergio}

Minha Luisa:

[14-6-09]

Recebi a sua carta, - e agora, que está tudo passado, devemos fazêr como os marinheiros que na calma discutem e analisam as peripecias do mau tempo que já lá foi, para tirarem d'ellas ensinamento 3 aproveitamento para o futuro. Pela ultima vêz, façamos um exame consciencioso, imparcial, desinteressado, e aquelle de nós que errou tratará de se emendar para ao diante. Accusou-me de não confiar em si, emquanto a Luisa creria em mim «cegamente». Vamos por partes.

Primeiro, não crê tal em mim: - porque, tendo-lhe eu dito que $v i$, que conheci determinada pessoa (não importaria muito ao caso, agora, que pessoa) e que a achei muito torpe, a Luisa ainda na carta de hontem - ainda! - continua nos seus elogios enthusiastas, protestanto contra «imerecidas opiniốes» [............ ] Se tanta impressão me faz o facto, uma das causas é porque logo na sua segunda ou terceira carta começou a endeusar o homem. Enguli, fui soffredoríssimo: limitei-me a dizêr que a achava "obscura», que deixava umas dúvidas para o futuro... Era o mais que podia, mal calculando que teria de engulir segunda dose, e aperfeiçoada. Vamos adiante. Segundo: lamenta que eu duvide de si. Mas, Deus meu, dou-lhe o direito pleno de fazêr o mesmo quando me vir em contradiç̧ões [........... ] Distrahidamente, sem querêr, sem reparar, por simples esquecimento, deixou-se levar a escrever coisas um tanto vagas. Não é lá muito grave, mas dê-me o direito de lhe pedir que d'hoje em diante tenha mais rigor, mais attenção, mais cuidadoso escrúpulo nas affirmações que fizer. Minha Luisa, os factos valem mais do que as palavras. Diz-me que crê plenamente em mim, 
mas mostrou-me contumazmente que não crê tal; diz-me que é toda franca, mas mostrou-me que o não é tanto. Quando o seu Antonio Sergio disser uma coisa que haja indícios de não sêr bem assim, pergunte-lhe, obrigue-o a explicar-se, e condemne-o quando elle merecêr.. Não quero que creia em mim «cegamente», como diz: quero que creia convictamente, porque vê, d'olhos abertos. Tenho muito prazêr em que olhe para dentro de mim, indague, esmiuce: nutro a esperança (que talvêz seja vaidade estulta) de que só tenho a ganhar com isso. Oiça as pessoas que me conhecem, saiba o que faço, o que digo, a todos os momentos, em todas as circunstancias. Recebo também cartas anónimas, mas a meu proprio respeito. Resumem-se a chamar-me homem sem sensibilidade, que os meus versos são mais de um filósofo que d'um poeta, que só sei «andar pelas alturas». Ora como «andar pelas alturas» é para mim a mais bella qualidade de um homem, em vêz de me incommodar lisonjeiam-me. Uma vêz falavam de si: seria talvêz da mesma criatura que lhe escreveu.

Ainda bem que concorda que vir dizêr-me a mim que tinha a «lembrança» do outro no «coração», faz pavor ao próprio inferno. Depois das minhas affirmações, então, é um cúmulo inaudito: comtudo lá está, indelevel, por mais que não quizesse acreditar. Não sentiu queimarem-se-lhe as mãos, nem a cabeça, nem os labios ao escrevêr; levou tão longe o seu enthusiasmo que tornou a minha posição caricata: a mais mesquinha dignidade impunha o dever de lhe pedir explicações. Não posso concebêr o seu estado de espirito ao dizêr aquillo [.

Eu prefiro a verdade dolorosa à illusão benéfica, mas reconheço que os que não são nisto como eu, são como eu tão dignos, e mais bondosos. Ora a minha Luisa evidentemente é mais bondosa do que eu. A paixão da verdade, a mim, faz-me duro, sacrifico-lhe tudo: é para mim importantíssima. E por isso que muitas pessoas, não conseguindo ir ao fundo, teem de mim opinião análoga à do tal anónimo que lhe escreveu; é por isso ainda que lhe perguntei se gostava do Hamlet: quem não gosta do Hamlet não pode gosiar de mim, e eu não quero que a minha Luisa vá enganada. Mas acho perfeitamente natural que se prefira S. Francisco de Assis a Hamlet, a minha Luch ao Antonio Sergio.

Já agora seguirei hoje no assumpto educação, caracteres, costumes. A quasi totalidade dos homens tende a fazêr da sua mulher uma coisa que se abisma na individualidade do seu marido, sem individualidade propria, sem iniciativa, sem pensamento, sem responsabilidade das suas palavras e dos seus actos. Não é uma companheira da sua vida, dos seus trabalhos, dos seus projectos; para isso servem os amigos. Portanto não a educam. É uma companheira de casa, uma governanta e um entretenimento. Toma só parte nas acções e nos pensamentos mais superficiaes e banaes do seu marido. Conhece o problema: é o da Casa de Boneca, de Ibsen. Todos protestaram contra as ideas do Ibsen, porque todos fazendo isto, todos acham natural. Deve têr satisfação em que eu jamais pensasse em fazêr o mesmo: por isso ligo importancia às suas palavras; por isso quero que se instrua, e que se interesse pelas coisas bellas. Precisa de estudar muito,- sempre, é claro, com a reserva de lhe não fazer mal. Muitas vêzes os homens não querem que as mulheres se instruam, por mêdo de perderem a sua superioridade; eu desejaria que a minha Luch, pelo contrário, se approximasse o mais possível do meu plano intellectual. Tudo, é claro, sem perdêr nenhuma das qualidades essen- 
cialmente e encantadôramente femininas. Há-de lêr os versos de Guyau. São bem poucos. Repare nisto:

\section{VISAGES ET ÂMES}

Je vois bien des charmants visages, De grands jeux, parfois bien osés, Et de petits yeux bleus très sages, Au sol modestement baissés.

Je vois bien des rondes épaules, Qui se découvrent sans regrets, Des lèvres ou deux mots frivoles Font perler de doux vires grais...

Comme on admire des statues, Blanches sous la charté des cieux, Toutes ces formes entrevues Peuplent ma mémoire et mes yeux.

Que vous manque-t-il donc, ô belles? Parfois, je vous en fois l'aveu, Je me demande: Vivent-elles? Hélas, elles pensent si peu!...

Quel Pygmalion, de son âme, Douces formes, vous animant, Vous dira: Vivez, soyez femme, Au lieu d'être un jouet charmant!

Laissez là ces mines guindées: Qu'on sente en vous courir le sang! Ayez pour les grandes ideés Un sein qui baïte, jeune et franc!

Tout ce qui dans vos coeurs s'implante, Faute de sève, s'amoindrit:

La science devient pédante, L'art se déssèche et se flétrit...

Toi qu'on dit fort comme la flamme Et la mort même, amour sacré, Pourras-tu remplir de mon âme La femme qu'un jour j'aimerai? Pourras-tu mêler nos pensées Dans Vivresse des grands essors?

Par instants, oubliant la terre, Nous envolerons-nous tous deux Dans cet infini solitaire Que nous peuplerous de nos dieux?

O toi que j'aime, et que j'ignore, Vers qui mes vers vont s'égarant, De toi je ne sais rien encore, Mais je te demande un coeur grand, 
Un noble coeur auquel soit chère

Toute clarté venant d'en haut,

Droit comme un rayon de lumière

Et comme lui vibrant et chaud!

Leia muitas vêzes isto, minha noivasinha, que tem de sêr o programma da sua vida.

A proposito ainda, um conselho. Não fui só eu o mal impressionado pela sua maneira de falar. Sei de várias pessoas mais. Tenho uma maneira singela e modesta de se exprimir. $O$ estilo da conversação deve sêr em zig-zag, despreoccupado, irregular, caprichoso, ingenuo, quasi humilde, quasi timido. Nada de frases regularmente construidas, nada do tom de quem dá uma lição, revela uma verdade, repele um conceito ou profere uma sentença. Em conversa, mesmo quando tratamos do mais eloquente problema de filosofia, devemos têr as maneiras de uma criança que conta uma brincadeira com a criada. São ellas, as crianças, os grandes modelos de naturalidade, de candura, de ingenuidade. Elias estão todas entregues ao que vão dizer, não pensam em mais nada, em si, no effeito que fazem. Assim se aprende ao mesmo tempo a estar em toda parte igualmente bem e à vontade, naturalmente elevados, naturalmente nobres, ã altura dos pequenos sem nos abaixarmos, à altura dos elevados e grandes sem fazer esforço. A Luisa dá a idéa de que não está entregue ao que diz: parece que despresa tanto o assumpto da conversa como a pessoa com quem fala. Dir-se-ia uma princêsa que não dá attenção aos seus vassalos: como tem que dizêr qualquer coisa, julgamos que repete uma frase já preparada, - e vae-se embora. Bem sei que não $\dot{e}$ assim, mas parece: faça o possivel para perdêr essa apparencia. Não e um aperfeiçoamento moral, mas por assim dizêr quasi físico: questão de gestos e maneiras. Neste ponto os manos Frederico e Valentina são perfeitos: dois fidalgos acabados. Gostava que os pudesse observar: completa natuarlidade, expontaneidade absoluta. Vi o Frederico um dia discutir historias com uma rapariguinha de 11 anos: digo-lhe que estava tão criança, tão ingenuo, tão interessado, tão innocente como a rapariguinha. Com a mesma naturalidade entra em combate, commanda um pelotão, estuda um problema de astronomia, e com a mesma se apresentaria a uma audiência do Imperador das Russias. Vim de casa d'elle, coitado, que está de cama com um febrão. É perto de meia-noite, e doem-me já os olhos porque tenho uma luz má no escritório. Minha Luch, coitadinha, teve de aturar um discurso muito maçador. Haja paciencia. Tome attenção ao que lhe digo nesta carta e faca por empregar nella o tal «sentimento innato de justica» que diz têr. Affianço-lhe que estou calmo, se bem que emmurhecido ainda, como uma planta que um verme mordêsse. Outro dia tive febre, e rugi de indignação e de revolta. Tudo isso passou, mas não estou ainda alegre, nem livre de um certo espanto e atordoamento. Não ha nada que resista a duas ou três pancadas como aquella. Emfím, eu bem sabia que a nossa união em espirito era coisa a fazer, longe ainda de realização: simplesmente verifiquei que estavamos mais atrazados do que parecia.

Minha Luisa: garanto-lhe que pelo que respeita à firmêza dos sentimentos confio absolutamente em si; que sabe atirar para longe todas as preoccupaçôes mesquinhas acaba de m'o provar. O meu amor, a minha consideração, o meu respeito ficaram já absolutamente intactos; não se préoccupé pois com o que eu «teria pensado afinal», como me disse na carta de hoje. Pode repetir muito certa 
para si mesma que o seu Antonio Sergio é muito seu e a ama muito; mas lembre-se de lhe fazêr sentir que o ama com toda a força que elle pode imaginar. Adeus, minha Luisa, meu amor, deixe-me têr a impressão de que lhe aperto muito as mãos e que lh'as beijo. Pertencemos desde já um ao outro, não é verdade? e respiramos já numa só vida. Minha Lueh, minha Luch: queria, minha pomba, senti-la vivêr no meu peito. Não se esqueça de sêr muito boa, muito meiga, muito acariciadora para o seu

\section{A. Sergio}

[15-6-09]

Minha bôa Luisinha: Não esteja abatida, minha flor, não ha motivo algum para isso. Nunca suspeitei da lizura dos seus sentimentos. Repito-lhe que sentiu uma coisa mas escreveu outra: a segunda parte da sua carta má foi escrita com o coração, e a primeira com a fantasia: eis tudo. Se eu lh'a desse a lêr perceberia o que não percebe. Foi uma falta de attenção: não reparou que o seu Sergio tinha dito umas coisas e que sem grandes razões não o devia contradizêr, principalmente com tanto fogo, e em tão delicado assumpto. Não me «escaparam», como diz, coisas cruéis: disse-as sabendo o que dizia; a sua carta obrigou-me a isso. Diz-me que precisa de sêr animada para mais não pensar em coisas tristes: parece-me que o tenho feito, meu amôr, mas diga-me que mais posso fazêr para a envolvêr numa atmosfera de caricias; não é por falta de vontade, minha rôlazinha, que a não encho de ternuras. Acordei muito cêdo, minha doce amada, e fiquei muito tempo a pensar em si, com grande desejo de a têr commigo: trata-la-ia com muito amôr, sacia-la-ia de meiguice. Se estiver de serviço na sexta-feira, seria sabbado bom $\operatorname{dia}^{\wedge}$ de nos encontrarmos. Encher-nos-iamos um do outro, com tanta sêde que d'isso temos; repita-me, Luisinha, que em espirito vive sempre commigo, em mim e para mim. Pede-me tanto que seja meigo, não sei se acha que o sou pouco: se tem muita satisfação em recebêr caricias minhas, não tenho eu menos em lh'as dizêr.

Esteja muito contente, alegre, feliz: encha-se de luz, respire muito bem pelo corpo e pela alma. Lembre-se de que a sua saúde me interessa muito mais que a minha própria, e tome muito cuidado com a sua cabeça, os seus olhos, o seu coração, os seus pulmões, porque são mais meus do que seus; todas as suas faculdades vão para mim, para se abismarem no meu amôr. Diga-me se sou mais, menos, ou tão «meiguinho» como me pede.

A Pilar queixa-se de que tem andado arisca com ella: crê que foi desde a história do concêrto. Veja se a attrai, coitada, que é estremosíssima commigo, e mais e mais dia a dia. Se fôr no sabbado fale muito com ella, e seduza-a quanto puder, para the tirar aquella impressão.

Fala muito bem do Misanthropo; eu entretanto também o acho impressionante, como o tal autor que leu, como acho sempre todo o homem que não tem a intelligencia e o coração à altura da sua bôa e honesta vontade. O pobre Alceste não tem uma alma grande, e é pouco intelligente: d'ahi uma paixão sem nobrêza; d'ahi o sêr cómico, e não trágico; d'ahi o seu carácter superficial e acanhado. Nas escolas 
conheci alguns rapazes muito estudiosos, cuidadosíssimos, exemplarissimamente comportados, mas tão acanhados de intellecto que faziam dó. Alceste em pequeno devia têr sido assim. A intelligência não se aggrega só ás qualidades moraes, transforma-as, dá-lhes outro aspecto. Pode-se sêr intelligente e baixo; mas um bello carácter, quando se junta a uma boa cabeça toma outro brilho, e muito maior profundidade. $O$ misanthropo tinha vontade de acertar, mas faltava-lhe tudo mais. D'ahi a melancolia que me produz a sua tristíssima aventura. É sempre doloroso vêr uma apreciavel qualidade absolutamente perdida por apparecêr desacompanhada; sempre doloroso o termos de rir de quem apparece com uma virtude rara. Seria este $0 \wedge$ sentimento com que o encararia o Hamlet: o sólido Horácio, esse, não era «escravo das paixões».

Já começou o Brunetière? Leia primeiro só o texto, a seguir, sem se importar com as notas-planos que o acompanham sempre. Leia depois as notas referentes aos escritores que a interessarem mais. Será bom fazer isto com Ronsard, Racine, Boileau, Rousseau, Voltaire, Chateaubriand, V. Hugo, Musset, Taine, Flaubert, Leconte de Lisle. Procure percebêr bem o movimento da Renascença, a doutrina clássica (exposta em Boileau, praticada exemplarmente em Racine), o Romantismo (Rousseau, Chateaubriand, V. Hugo...) e o Naturalismo (Flaubert, Taine, L. de Lisie). Veja que cada uma d'estas palavras indica uma maneira geral de concebêr o homem, as coisas, a sociedade, a arte, maneira que se revela na política, nos costumes, $\wedge$ nas obras, quer de literatura, quer de pintura, quer de musica, etc. É romântico por exemplo, (não saindo da França) o romance de Chateaubriand, a poesia de Musset, a crítica de Sainte-Beuve, a historia de Michelet, o theatro de V. Hugo, a pintura de Ingres e Delacroix, etc., a política de Lamartine, os costumes, as ideas, as maneiras, os sentimentos. O mesmo se dirá do Classicismo e do Naturalismo. Como vê, é preciso conhecer a historia para comprehender a Arte. Deverá estuda-la pois como preparativo e introducção á Esthetica, estudo do bello, estudo das artes. $E$ a este estudo que vae dedicar-se, como sendo o mais interessante, o mais agradável, o mais fácil, o mais proprio para o seu sexo e aqquelle para que já tem mais elementos. Examinada a producção da obra d'arte, seus elementos, suas condições, sua naturêza, - em geral —, poderá dedicar-se a conhecer mais detalhadamente uma arte que escolhêr: pintura, esculptura, música, poesia, etc. Tudo isto é de fácil comprehensão, não tem nada de pesado, de árido ou de pedantesco. Se fôr para os Vargos levará a Philosophie de VArt de Taine. Não se espante com o título: são coisas simplicíssimas, elementaríssimas. A palavra filosofia tem dois sentidos geralmente: um que indica um determinado estudo sui-generis, muito difficil, muito abstracto, muito complicado; o outro indica a teoria geral de qualquer assumpto: é assim que se diz a filosofia da chímica, a filosofia das paixões, a filosofia do amôr, a filosofia botânica, a filosofia da arte, a filosofia do casamento, a filosofia social, etc. Fará pequenos caderninhos e resumirá cada obra d'esthetica no respectivo caderninho, para eu depois vêr. Concorda com este plano? Um dia, quando fôr mais sabiazinha, poderá escrevêr um pequenino ensaio, uma análise, uma crítica... e fazêr alguns rabiscos nos papeis do seu marido...

Adeus, minha Luisa. Quis desfazêr em si todas as sombras, e cumprir o que me pediu: se acha que exaggerei na ternura ou na familiaridade, faça-mo sabêr, diga o que quer, e farei tudo que mandar

A. $\mathbf{S}$. 
Minha Luisa:

Acabo de chegar de casa do pobre Chagas, que continua bastante doente. Não tencionava escrevêr-lhe hoje porque, mal impressionado com a sua carta, esperaria desfazêr essa impressão com a de sexta-feira. Como porém virá cá no sabbado, quero que já então esteja tudo liquidado, para que tenhamos um dia verdadeiramente bom. Dê-me uma resposta definitiva. Estão de pé outra vêz as coisas «cruéis». Diz-me que não crê «cegamente» em mim. Não me é novidade, demais o provou. O que eu disse é que não desejaria tal, se tal acontecêsse. Mas o que succedeu foi o seguinte: $10^{\circ}$ a Luisa não acreditou o que lhe eu disse com provas; $20^{\circ}$ acreditou cegamente, ceguissimamente, sim, e acredita, mas é... no Joaquim Machado! Continuamos em comedia. Affirma-me que se lhe mostrassem provas contra mim mais facilmente duvidaria das provas. Não sei se fazia isso commigo, mas sei que o faz admiravelmente com elle. Por outro lado, não se esquece de me dizêr que me "posso enganar"... Não é pertinácia que lhe falta. Peço-lhe resposta da penúltima carta. Tem ou não tem intelligencia sufficiente das coisas humanas para distinguir um homem honesto de um safardana? Acabe de vêz com esta situação deprimente de me desmentir a mim para endeusar um biltre. Não haja idea alguma occulta, descubra até ao fim o seu pensamento. $L$ impossivel addiar seja o que fôr sobre questões de verdade, porque hoje, amanhan, depois, sempre, serei sempre incansável a pedir-lhe a verdade absoluta, em coisas grandes ou pequenas, que isso para o caso nada importa. Para que eu possa socegar faca-me a esmola de dar respostas claras, rigorosíssimas, concisas, definitivas, a estas três perguntas, ou quatro:

1. ': Acredita ou não no que digo?

2. ${ }^{\circ}$ : Atira ou não o seu heroe para o lodo que merece?

3. ${ }^{\circ}$ : Porque se contradiz?

4. ${ }^{\circ}$ Promette ou não em tudo sêr transparente como agua?

Tudo isto, Luisa, me custa extraordinariamente, mas mais extraordinaria foi a sua idea e pertinácia inconsciente de me fazêr engulir á força a canonização de $S$. Joaquim Machado Fadista. E capaz de estranhar muito a minha insistencia, mas eu estranho mais ainda a sua, e o seu louco enthusiasmo. Nunca esperei ter comsigo tão mesquinha discussão, mas não sei porquê a Luisa nada tem feito para desfazêr positivamente a impressão fulminante da sua extraordinarissima carta. Tenho ainda uma carta da Ruth, que lhe poderia mostrar, e onde me diz que a Luisa, em se tratando do J. M., era surda. Será verdade?

Seu humilde e respeitosíssimo

\section{Antonio Sergio}

17, pela manhan (Junho, 09)

Minha Luisa bem-amada, querida Luisa do meu coração: Passei toda a noite incommodado pela carta desalentada que lhe escrevi hon- 
tem. Se soubesse como me sentia cansado, abatido por não ter desfeito a impressão d'aquella malfadada carta sua! A minha Luisa sente muito bem com certêza, mas por má sorte não escreveu como sentia. Peço-lhe que esteja calma, e me mande agora dentro de qualquer coisa duas palavras a dizêr-me que está tão bem quanto pode, que não está mal com o seu Antonio Sergio, que só tem afinal o defeito de sêr muito sensivel com tudo que vem da sua querida Luch. Peço-lhe mil perdões do mal que teem suscitado as minhas ${ }^{\wedge}$ palavras, mas pode crêr que se lêsse de fóra as suas havia de procedêr como eu fiz. Creia ainda que a amargura das minhas cartas só vem do soffrimento que me dá a idea de qualquer dúvida entre nós. Se fosse possivel indicar-lhe o meu sentimento sem ao mesmo tempo lhe fazêr tristeza, ou melindre, ou amargor! Fico esperando duas palavras calmas e boas, e não deixe de mandar os retratos amanhan. Tenho a impressão de que os novos retratos me falarão mais da minha Luch, a minha Luch cujo bem-estar eu desejo sobretudo. Pede-lhe mil perdões e beija-lhe carinhosíssimamente as mãos o seu noivo muito amante

\section{A. Sergio}

P. S. Se pudér mandar os retratos agora dentro de um livro, faça-o.

Minha Luchezinha da minh'alma:

[17-6-09]

Tudo acabado, tudo acabado, tudo acabado, de vez, completamente, para sempre! Agora sim, bemdita seja a sua carta! Para sempre, não é verdade? - nem mais uma sombra ha-de haver entre nós dois, até que a morte venha ceifar aquelle de nós que irá primeiro. Quereria que lêsse esta carta chorando de alegria. Beijo em imaginação esses olhos queridos por cada lágrima que lhes fiz verter. Espero vế-la entrar no sabbado sorrindo, radiante, expansiva. Sentir-nos-emos definitivamente nós:

Realms where the air we breath is love.

Comecei emfim com o Shelley e roubo-lhe este verso do Prometheu Libertado para o mandar á minha Luch.

Muito obrigado pelos retratinhos. Fiz mal em lhe pedir tantos, mas pelo que me disse julguei que já tinha mandado tirar todos (de todas as especies) e que tendo já em seu podêr provas de todos, me dava a escolhêr. Se soubesse que ainda não tinha mandado fazêr de tudo não teria sido tão ambicioso. Gostei d'elles, mas vejo que tenho de desistir de não vêr a minha Luch desfavorecida nos retratos. Só então os meus é que ficam melhores do que sou! Repito-lhe que gostei e que os acho superiores aos outros de poupa e a olhar para o lado, mas acho-os também muito àquem do original...

Se amanhan me falar às onze (ou das onze em diante) quero senti-la muito alegre. Não se admire se me ouvir grave e conciso: a casa do telefone está quasi sempre vasia, $\operatorname{mas}^{\wedge}{ }^{\wedge}$ s̃o mesmo ao pé uma secretaria com vários amanuenses e o gabinête do almirante, - que não é nenhuma fera, coitado, mas cuja majestade de barbaças eu iria 
chocar com as rútilas expansões da minha mocidade e do meu amor... Fica avisada para sempre: nunca estranhe de vêr que sou sêcco ao telefone, ou muito grave, ou que interrompo subitamente a conversa, ou não respondo a qualquer pergunta, ou me calo sem dar a entendêr porquê, etc. Se lhe falar alguma vêz sem sêr do Quartel, como ha dias, direi tudo como recado da Pilar, para o que inventarei combinações entre si e ella, passeios, etc. $A$ bom entender...

Destrua a minha carta de hontem, e nunca se esqueça dos versos do Guyau. A propósito, vou-lhe mandar uns de Charles de Porn airols que agora me occorreram:

\section{CONDITION}

1 Ah! je suis un coeur infidèle, Un coeur trop peu semblable au tien; Je ne sais aimer que le Bien, Cet idéal et froid modèle.

2 Je t'adore présentement, Parce que ton âme parfaite Chaque jour me donne la fête D'un éternel enchantement.

3 Mais entends l'aveu, quoique étrange: Je cesserais de te chérir, Si tu cessais de me ravir Par tes exquises boutés d'ange.

4 Car enfim tu n'es pas mon sang, Je ne t'aime pas comme un père De cet amour involontaire Qui se gagne vieu qu'en naissant.

5 Si profond que je l'imagine, Mon amour, jadis né du choix, Ayant été libre une fois Se souvient de son origine.

6 Qu'adviendrait-il, si tu changeais?... ...Non, je vis, je n'ai pas la crainte, Ta vertu stable sans contrainte T'assure mon coeur à jamais.

Gostou? E agora, uma pergunta: eu realizo, Luisinha, completamente o seu ideal? Faltar-me-hã̃o faculdades, força de alma, sensibilidade, elementos, o que quizerem: mas pode estar convencida, meu amor, de que não podia encontrar melhor boa vontade e coração mais puro, mais cioso do aceio moral de si mesmo. Se houvesse Deus, e Deus falasse às criaturas, estou seguro de que lhe diria: «Podes ir com elle, minha filha, que sem acreditar em mim esse viveu sempre, desde que lhe dei intelligencia adulta, como viveram os meus santos, candido e innocente á face do Senhor; elle, que estudou todas as ideas, moraes e immoraes, com o espirito completamente livre de todas as regras, todos os preconceitos, todos os dictâmes». Porque na realidade nunca ninguem me dictou leis ou disciplinas, e segui sempre o meu 
instincto. Meu Pae nunca me indicou um principio, minha Mãe nunca me ensinou uma oração. Sentiu elle que não era preciso, viu bem como eu era? Creio que sim: já o não tenho infelizmente, para lhe fazêr interrogatorio... Digo-lhe isto porque sinto doçura em me expandir assim comsigo, não por vaidade ou por orgulho: não pode havêr vaidades entre nós, somos absolutamente humildes um com o outro, porque somos a mesma pessoa. Não é assim, minha Luisa? trato-a absolutamente como a mim mesmo, a sua vida é vida minha, a sua alma é minha alma. O que um pensa o outro faz, como faz o meu corpo aquillo que pensa o meu pensamento... A Luisa pertence-me de uma maneira absoluta, não porque esteja sujeita á minha pessoa, como tantas mulheres escravizadas, mas porque se confunde commigo, o que é muito differente. Pertence-me a mim como eu a mim mesmo me pertenço. Diga-me se concorda com isto, se é isto que sonha e quer.

Adeus, minha Luisa, receba a sua alma um grande abraço e um grande beijo que lhe dá o meu espirito, ajoelhado em oração num dia de sol purissimo.

A. S.

P. S. O retrato à americana acho-o m. . $^{\text {to }}$ elegante. AS.

Quartel, 18 de Junho, meio-dia (09)

Escrevo-lhe a olhar para o seu retrato. Sim, meu amôr, percebe-se, percebe-se o que me pergunta - e não calcula quanta doçura o seu Antonio Sergio nisso acha! Gosto muito d'elle, mas é mais bello o original. Minha Luisa, minha Luisa...

Faz-me lembrar um pouco a Joconda do Leonardo, mas a Joconda é fria, e o seu retratinho não é, - ou, pelo menos, é fria em comparação com elle. Como acabo de the dizêr ao telefone, posso restituir-lhe dois. $O$ que talvez precise é de outro pequeno igual a este para quando este se estragar, - porque lhe dou muito uso, estou sempre a tira-lo da carteira. Agora reparo que comecei a escrever com o papel ao contrário. Tenha paciencia.

Diz muito bem que ha-de ser a minha companheira em tudo. Quero que me ajude muito nas minimas coisas que eu faça, não pela ajuda em si, é claro, mas para que nos unamos muito juntinhos precisamente nas aeçóes mais bellas, mais fecundas, as que mais ficam de uma existencia. Se vivessemos como hoje ha mais tempo havia de têr escrito uma página do Anthero ainda que eu tivesse depois de a copiar para ir com a minha letra para a tipografia. Não se esqueça nunca que tem a realizar commigo a dedicação perfeita, absoluta, modelar; que cada um de nós hade fazêr que o outro dê o mais que pode dar, suba o mais que pode subir, produza o mais de que fôr capaz, desenvolva até o máximo todas as suas faculdades. Passaremos a vida a animarmo-nos, a ampararmo-nos, até que um dia possamos dizêr orgulhosamente que o termo-nos encontrado foi das maiores felicidades, foi a verdadeira SORTE GRANDE da nossa existencia.

Agora recordo que as ultimas paginas do meu livrinho foram revistas comsigo. Lembra-se, meu amôr? Que bem que isso me soube! 
Na casa de jantar, á noite, a Pilar escabeceava na cadeira de palha... Tive um prazêr enorme em a consultar sobre se devia ou não exarar uma cita no inferior da pagina. Iria jurar que a Luisa teve então, como eu, um devaneio vago de futuro, e sentiu uma doçura secreta naquelle trabalho ao pé de mim... Que me retinha e desanimava? A minha pobrêza, a pobrêza só, a que somente via esse inconveniente, porque por mim nunca ambicionei têr mais do que o que tenho.

Amanhan, meu Deus, que dia d'oiro poderá ser! Esteja muito à vontade commigo, porque no seu Sergio não ha peçonha. O meu lago não se turva, o meu ceu é sempre estivo. Fale commigo como d'antes, ou por outra lembre-se de que é minha irman, e não ha pois que «têr vergonha de deixar transparecêr o que sente lá por dentro...»

Minha rôla, meu amor, como o seu noivo a ama! Luisa, Luisa...

A. S.

P. S. Tire o chapéu depois de entrar, gosto mais de a vêr em cabello. $O$ tal penteado, é claro.

Não se esqueça do que me diz: é preciso que venha a têr muito orgulho na minha mulherzinha. Como lhe agradeço esses desejos!

Sinto baterem á porta,

Não és tu; porque não és?

Só uma coisa me importa,

O ciciar dos teus pés.

São teus olhos columbinos,

Columbino o teu andar:

Quaes pombos brancos, meus hinos

Vão para a pomba a voar.

Sinto passinhos na escada

Bate um e um; eu então

A cada dôce pancada

Sinto outra no coração

Sonho que vens de branquinho,

Toda de branco vestida:

Vamos a vêr se adivinho,

Ó vida da minha vida.

Estou impaciente; escrevinho

Para que o tempo me passe:

Oh se por cada vèrsinho

A distancia se encurtasse!

A esfera azul é mais clara;

Eis logo a aragem que vem

Dizer-me que se prepara

A recebêr o meu bem... 
Vou cantar a minha amada, A Naturêza me anima:

As aves dão-me a toada,

Os lirios vem dar-me a rima.

Eis a menina do lado,

Coitada! Pobre donzella!

Procura o seu namorado

Occulta pela janella

Cae uma gota, outra tomba

Na fonte d'aquelle jardim:

Porque não vens, minha pomba,

Porque te afastas de mim?

Sinto passarem os ventos,

Oiço cantarem pardaes:

São tudo contentamentos

Nos ramos e nos beiraes

Troçando commigo, a brisa

Diz-me segredos risonhos:

«Já sei, Senhor, que é Luisa

O nome que diz nos sonhos...»

«Segue-o de noite o olhar vivo

D'uma espertíssima estrella:

Não seja muito expansivo,

Precisa de ter cautella...»

Indo-se embora, sorria

Troçando com ar de festa:

«Julgava que me illudia?...

Só me faltava mais esta!»

Já vae a leve andorinha

No ar immenso a correr:

Tudo no ceu diz que és minha,

Tudo na terra é prazêr.

Resôam por toda parte

Os trilos de alguma lira:

Bemdições que a luz reparte

A todo o sêr que respira.

A acompanhar estas arias

Tudo me fala de ti

Tudo me diz coisas varias:

«Eu a vi, eu a não vi...»

Ai que o meu bem me não ama,

Ai que o meu se me esconde:

A minha voz tanto a chama,

Á minha voz não responde.

Fujo de um lado a outro lado,

Corro de um canto a outro canto,

Repleto do meu cuidado,

Cheio de mêdo e de espanto... 
Começo a perder a esp'rança,

O ceus, que idea tão má...

O coração não descansa,

Senhor, Senhor, não virá?

Tenho na alma uma guerra,

Com treva e luz aos baldões:

Não ha ventura na terra

Isenta de inquietações.

19 de Junho (09)

Minha irmanzinha e minha Virgem:

Como eu lhe estou grato, como lhe estou grato, como lhe estou grato! Juro-lhe, Luisa, que sou absolutamente digno da confiança que em mim tem. Como calcula, não tenho podido pensar senão em Si. A impressão que agora me enche é, na sua exclusividade e na sua grandeza, curiosissimamente extraordinária. Esperava tê-la, mas não imaginava que viesse a sêr tão exclusiva e dominadora: é a impressão da santidade do meu amor. Tenho lido, visto, ouvido tanto sobre o sentimento amoroso, conheço tantas analises subtis de todas as nobres variedades d'esse sentimento, e no entanto não conhecia, não suspeitava d'esta feição tão especial do que eu sinto. Amo-a como se ama Nossa Senhora... Terá acaso havido mulheres mais amadas, não quero sabêr: não o houve certissimamente melhor amada, mais cristalinamente amada do que a Luisa. Se lêssem esta carta, noventa e nove por cento dos homens rir-se-iam de mim ou chamar-me-iam doido.

Si vous saviez que je vous aime,

Surtout si vous saviez COMMENT,

Vous entreriez peut-être même,

Tout simplement...

(Julies Prudhomme, Prière)

Estou-lhe falando, Luisa, como a mim mesmo, não ha considerações, não ha preconceitos, não ha pensamentos que se interponham entre a minh'alma em si e a minha mão que está escrevendo. A minha ruminação interior não soffre variação alguma pelo facto de lhe sêr tjransmittida. Quando lhe falo sigo o meu monólogo íntimo absolutamente como se lh'o não estivesse transmittindo. Comsigo não tenho a impressão de estar conversando com alguém, mas sim a de estar a pensar solitário. Seria quasi absurdo o dizêr-lhe neste momento que a amo, como dizêr-lhe, por exemplo, que o sol dá luz. Não lhe saberia mesmo escrevêr agora uma palavra amorosa, porque me daria a impressão de a escrevêr a mim mesmo. Isto não é mesmo uma carta, mas um rápido apontamento íntimo sobre o dia mais extraordinário e mais importante da minha vida. Parece-me que não levei meio-minuto a escrevê-lo. Sinto-me absolutamente tranquillo, puro e com uma grande felicidade muito calma. 
Adeus, minha Luisa mais-que-amada. Bemdita seja, bemdita seja, bemdita seja

\section{A. S.}

P. S. Acabei de jantar, vou ao Frederico. As suas cartas costumam vir mal fechadas. Oxalá goste do passeio, e seja muito boa com a Pilar.

Minha adoradíssima Luisa.

19, 11 da noite (Junho - 09)

Escrevi-lhe depois de jantar uma cartinha que lhe peço que leia antes d'esta. Volto do Frederico, que está muito melhor.

Minha adoradíssima, adoradíssima, adoradíssima Luisa: todo eu sou amôr por si. Tenho estado atordoado, allucinado pela sua imagem, pela imagem d'essas mãos queridas que sinto agarradas ao coração. Que alta, que nobre, que generosa, que pura que foi commigo! Só agora, um pouco mais em mim, começo bem a agradecêr ao destino os momentos de profunda, de infinita felicidade que tive hoje. Só a recordação d'essa felicidade é uma felicidade tão grande! Minha Luisa, minha Luisa, como me satisfaço completamente no meu amôr, que celeste embriaguêz, que plenitude de vida que em mim corre! Como eu a amo, como eu a amo!

Luisa, estou doido de amôr por si; estou doido de amôr por si porque a amo immensamente, não porque não seja de um amôr calmo, profundo, consciente, claro, puro como nenhum. Vejo no ar as suas mãos santissimas e adoro-as como relíquias. Não lhe diz lá um illuminado instincto que eu sou eu, e que me pode tratar como um irmão? Pode, pode Luisa, não tem nada que se defendêr de mim, juro-lhe por tudo que pode haver para mim de sagrado, de imponente, de respeitoso. Não sei se haverá no mundo outra criatura com direito de falar assim, mas eu tenho, por alma de meu Pae que tenho. Rogo-lhe de joelhos que me trate sempre com a mesma confiança de hoje, porque o mereço. Nunca, nunca desconfie, sou completamente incapaz de me aproximar de si hoje em dia com o mínimo laivo de sentimento impuro. Comprehende-me, minha Luisa, comprehende-me?

Luisa, alento do meu alento, vibração da minha luz, aragem que me faz cantar como nas cordas de uma lira d'oiro: como a larguêza e altura do seu procedimento a elevou a meus olhos! como eu a venero mais que nunca!. Tenho para comsigo um sentimento novo: o respeito filial. Interpretei muito bem as suas palavras e os seus gestos. Tratou-me ao mesmo tempo como a um irmão e a um filho. F com que immensissimo respeito e gratidão lhe fiquei! Nunca venerei, nunca venerei pessoa ou coisa como agora a venero a si. Minha Luisa, foi perfeita; fiquei ajoelhado ante o seu alto espirito, teve para commigo a conducta ideal, que eu vejo assim porque a sei interpretar como ella foi no seu íntimo. Toda a minha ambição seria estar no seu conceito a metade da altura em que hoje ficou no meu. Mas fiquei, certamente, ou por outra já estava, porque tudo em si me 
mostrou a conta em que me tinha, - justa, Luisa, justa, torno a repetir que completamente a merêço. Trate-me em tudo como a um irmão, deixe-me trata-la como a uma irman em tudo, porque nós somos nós, nascemos á altura um do outro. A que grande altar a elevei hoje ha-de vêr nas minhas maneiras de ora em diante. Uma criança pequenina não vae com mais humilde confiança e veneração soccorrer-se da sua mãe numa occasião afflictiva, - do que aquella com que eu hoje dou a guardar a minha alma e o meu futuro ás suas mãos bem-amadas. As suas mãos bem-amadas! O que a imagem d'essas mãos são hoje para mim é impossivel que o calcule alguém. Ah minha Luisa, o que eu sinto agora por Si basta para enchêr uma existencia! Luisa, Luisa, Luisa, estou doido de amor por si...

Não sei se se morre de amor, mas sei que de amor se vive. As suas mãos, as suas mãos! Jamais me poderão sair da imaginação, trago-as cá dentro como dois lirios. As suas mãos! Columnas do portal de um templo onde eu queimo o mais puro insenso, urnas da agua santa que me ha-de curar todas as dores. Minha Luisa as suas mãos ficaram santas para mim, deixe-as supportar pacientemente todas as effusões do meu culto. Dê-m'as, dê-m'as, dê-m'as...

Chegou a Pilar, enthusiasmada com o passeio. Até amanhan. Mostrar-nos-emos indifferentes quasi, para o publico, mas em havendo uma pequenina occasião faça-me sentir por uma palavra surda, por um olhar, de qualquer maneira, que sou o seu

Ant. S.

42

Minha Luisa muito minha e muito querida

[20-6-09]

Só lhe posso dizêr duas palavras por sêr mais de meia-noite e têr reparado que já não tenho estampilha alguma na caixa: hei-de pois procurar uma ainda, o que ha-de sêr difficil, hoje, domingo e a estas horas.

Fui tolo em lhe falar da minha partida. Não é para tão cêdo, e temos tempo ainda diante de nós, felizmente. Mas a perspectiva de um mês e mais dois separado da minha Luch aterrou-me... Esteja pois alegrezinha. Tomáva-me já amanhan para lêr a sua carta: oxalá ella seja tão amorosa quanto eu quereria! Adeus, minha querida Luch. Beijo as minhas Mãos com muita veneração e muito amor

A. S.

P. S. Compuz-Lhes hontem às [sic] noite uns versos, ás minhas Mãos, ao adormecêr. Se me lembrar mandar-lh'os-ei amanhan. 
21 de Junho, 1909

(À tarde)

«Pobre do meu coração! A tua ultima carta pô-lo num estado singular: tres saltos me dava no peito que parecia forcejar por arrancarse de mim e voar para tì. Isto diz a Marianna Alcoforado na sua primeira Carta, minha Luisa: isto é exactamente o que senti hoje lendo a sua. Mas ella estava triste, e eu sinto em mim uma felicidade inexprimível... Ella a freirá, já se vê, que a sua adoravel cartinha nada tem de triste, - muito antes pelo contrário.

Muito obrigado pelo bocadinho de telefone, que não esperava. Uma palavrinha de dia pode sempre sêr sem inconveniente; - e assim, durante um serviço falar-nos-emos três vezes. Diga ao homem que è de minha casa. Amanhan de manhan é escusado, porque não estou. Sairei do quartel ao amanhecêr para ir buscar com um pelotão quinze degredados a Paço d'Arcos. Serviço pouco agradavel, este de custodiar facínoras.

Hei-de dar-lhe uma porção de sobrescritos dirigidos a mim para os Vargos com letra do França: é assim mais prático do que o sistema que primeiro combinámos. As minhas ser-lhe-ão dirigidas a elle para depois as pôr no correio à hora que lhe parecêr melhor (naturalmente à noite, não?). Por mais que isso me custe, recommendo-lhe que me escreva todos os dias um poucochinho, mas envie espaçadamente, - para ahi de semana em semana, ou pouco menos. Um diariosinho curto, mas muito affectuoso. Farei o mesmo.

Hontem á tarde, ao voltar de casa do Frederico para jantar, trouxe commigo a Tempestade de Shakespeare que encontrei sobre a mêsa por acaso, para me vir entretendo no caminho até casa. Achei graça abrir logo numa scena que lhe vou transcrevêr. A historia se bem me lembro é isto:

Havia um duque de Milão, Prospero, com uma filha, Misanda... Perdão: era uma vêz um duque Prospero e uma filha Misanda... O duque, todo apaixonado pelas artes e pelas letras, exclusivamente dedicado a ellas, encarregou um irmão, Antonio, dos cuidados do governo, e tornou-se progressivamente extranho ao Estado, perdido que andava em seus estudos... Como seria de prevêr, traição de Antonio, que se ligou com o rei de Nápoles, e d'ahi expulsão do duque e da filha, que foram parar a uma ilha deserta. Mas Próspero tornou-se senhor de uma divindade aerea que fez naufragar na ilha o navio em que iam Antonio, o rei de Napoles e o filho d'este, Fernando. Prospero arranja que Fernando vá têr a um ponto da ilha differente d'aquelle a que chegam os outros, e approxima-o de Misanda, porque gostando muito do rapaz os quer casar. Misanda è uma virgem ideal puríssima e boníssima, e como seria de prevêr também, as duas bellas criaturas gostam logo uma da outra. E entre os dois que se passa o diálogo a que me refiro. Ahi vae elle, e diga-me o que lhe faz lembrar:

\section{Misanda:}

...And all the more it seeks (*) to hide itself, 
The bigges bulk it shows. Hence, bashful cunning!

And prompt me, plain and holy innocence!

I am your wife, if you wil marry me;

If not, I'll die your maid: to be your fellow

You may deny mee; but I'll be your servant,

Whether you wil or not.

\section{Fernando}

And y thus humble ever.

My mistress, dearest,

\section{Misanda}

My husband, then?

\section{Fernando}

Ay, with a heart as willing

As bondage e'er of freedom: here's my hand

\section{Misanda}

And mine, with my heart in't.

Incantadôra esta Misanda, não é verdade? E para acabar com a historia, ahi vae por minha conta uma frase de Fernando: «I, beyond all limit of what else in the world, do love, prize, honour you». Minha Luchezinha, minha Luisa... Estou a vế-la como hontem, de pé, toda vestidinha de branco. Se tivesse um annel nos seus dedos por cada vêz que penso nelles, as mãos da Luchezinha eram as mais ricas d'este mundo. Quantas horas passaria eu a beijar essas mãosinhas... Ah! esqueceram-me os versos: ficarão para outra vêz — Quando puser as suas mãos nas minhas que venha nellas o coração também, como nas de Misanda. Não é certo que as mãos são a feição, por assim dizer, expressiva, significativa, simbolizadôra, nas criaturas bondosas? Ha um «milagre» de Maeterlink (Soeur Béatrice) em que a estátua da Virgem Maria se anima para substituir uma freirá ausente. Uma criancinha que a vê, pergunta-lhe porque tem Ella luz nas mãos... «Il y en a toujours aux mains qui font l'aumône», responde a Virgem. Não se admire pois a minha pomba de que lhe eu fale tanto nas suas. As mãos não revelam o futuro, mas indicam muito bem um temperamento e um carácter.

Tomára que acabe o Doumic, que a deve estar maçando. Oxalá o Brunetière a interesse vivamente. Emprestei um volume d'elle à D. Valentina, que por acaso ainda o não conhecia, volume que lhe agradou muito. A proposito: disse-me ella que a romancista D. Anna Ribeiro de Sá lhe disséra que o estilo do meu Anthero era «perfeito». Não mereço a lisonja, mas communico-lh'a para lhe dar um prazêr, certo de que a apreciará mil vezes mais do que eu.

Adeus, meu amor, farei tudo o possivel para chegar a Lisboa a tempo de ainda ir amanhan á estação do comboio. Tenho quasi a certêza de o conseguir. Que boa idea têve! Já tinha pensado nisso, mas não julguei possivel. Por causa de me falar á noite ao telefone não fuja muito dos passeios de automóvel, para não desanimar o seu Pae e para se não privar de uma distracção util á saude. Olhe que não é para sêr amavel que lhe recommendo cuidado com ella, mas 
porque na realidade me interessa muito. Adeus, adeus. Gostava de que a minha face pudesse ir como esta carta descansar nas suas mãos. Ame sempre com toda a alma o todo seu

Ant. S.

Minha Luchezinha:

[23-6-09]

Mando-lhe três volumesinhos que ha-de têr o incommodo de lêr, e os sobrescritos escritos pelo França. Está a Pilar a escrever-lhe no meu escritório, e por isso vae esta a lapis, no meu quarto. Pela mesma razão lhe mandarei só logo pelo correio os versos, que receberá amanhan.

Venha pois na sexta-feira, e lembre-se que vamos ficar depois muito tempo sem nos vermos: terá portanto de sêr muito boa com o seu Antonio Sergio, que a ama como a minha Luchezinha bem sabe. Adeus. Procure sempre as minhas cartas na pag. 178 dos livros (Meu antigo numero do Collegio Militar). Uma grande saudade do seu noivo muito amante

Antonio Sergio

Vespera do São João de 909, 8 H da noite.

Minha querida irmanzinha e companheira. Tencionava passar toda esta noite em casa e escrevêr-lhe là para as onze da noite, mas de casa do Chagas chamaram-me pelo telefone. As meninas que lá se reúnem vão fazer sortes e reclamam-me. Não lhes posso dizêr, minha pomba, que não esperei pelo $S$. João para me noivar, - e lá irei, depois de eserevêr duas linhas á minha Luch.

Não calculei que esperasse tanto carta minha, quando não teria escrito. Perdôa-me, Luisinha, e deixa-me que te trate por $t u$ um momento, só um momento, para voltar já ao costume antigo...

Penso agora no que será ainda um serão em nossa casa. Depois de a minha mulherzinha têr cantado, sentar-nos-emos muito abraçados a uma mêsa de trabalho e lerêmos juntos o nosso estudo d'essa noite, discutindo em commun todas as coisas. A sua cabêça ficará á altura dos meus lábios, a tentar um beijo muito calmo, - tão calmo como as horas que passarão, batidas lentamente num relógio de parêde. Se fôr noite de S. João, ouviremos como agora as bombas, os gritos, os cantares, que me fazem um devaneio nostálgico de coisas vagas que eu fantasio, mimosas, ligeiras, aladas, deleitando como uma harmonia, seduzindo como um sonho, maravilhando de delicias como uma floresta fabulosa... A minha Margarida vae a uma festa, e a mim que a não posso vêr nem me deixam ao menos que fique escondido na minha cella. 
Recordo saüdosamente as noites dos Vargos no verão passado: sòmence a minha melancolia de agora me não deixa representar precisamente a alegre expansão d'essas noites bellas. A minha Lueh cantava, e eu ia desfrutando encantado a sua figurinha airosa. Gostava muito das expressões da sua bôca no "Voulez-vous bien ne plus dormir...». Quanto daria eu para lêr aqui agora essa boquita, a ciciar canções melifluas!... Minha Luizinha, meu amor, ha-de depois de amanhan dizêr ao seu Sergio que o ama muito, hei-de sentir que com a sua mão me dá também a sua alma, para eu a conservar entre as minhas, como um passarito que se agarrou. Tenho muita pena de têr de largar agora este papelzito que com tanta vontade estou enchendo, para ir assistir às sortes. Paciencia. Adeus, minha Luisa muito minha. Já acabou o Doumic? Tomára vê-la em coisa mais atrahente. Estude, meu amor, estude quanto pudér. "Uintelletto nutrica i'affetto. Chi più conosce piíi ama; $e$ piii amando piii gusta». Nunca se esqueça d'esca frase, que tanto lhe tenho repetido. A alma engrandece-se de toda a corrente de pensamento que por ella fazemos passar. Só duas pessoas que percorrem muitas ideas é que teem sempre assumpto, sempre conversa, sempre acção em commum, sempre communicação, sempre amor. Só assim conseguiremos realizar o conselho do Lafontaine, na sua fábula dos dois pombinhos:

«Soyez-vous l'un à l'autre un monde toujours beau,

Toujours divers, toujours nouveau».

Beija-lhe respeitosamente as mãos o seu marido respeitosissimo

A. S.

Minha Luisa:

Gostei immensa, completamente, da sua carta de hoje: «Meu Sergio, havemos de trabalhar muito, aproveitar bem o tempo;... torna-lo útil para a humanidade e para o Bem deverá sêr o primeiro objecto da nossa vida». Nunca se esquèça d'estas palavras, minha Luisa, nunca se esquèça um só momento; pense tanto nellas que as imprima na sua alma como aspiração, plano, emprègo, mira de todos os instantes. As condições da minha existência, a falca de direcção, a ignorância (em que ainda estou) do ramo para que tenho mais aptidões, tudo se tem juntado á minha preguiça para me fazêr perdêr tempo para a producção. Depois, nunca me lembro da producção, vou atrás de toda a especie de ideas, como um gourmet que come exclusivamente por prazêr, como um jogador que só joga para se divertir, e não para tirar do jogo um ganho posicivo. Desprezei sempre a producção, e só entrei nella arrastado pelo França e pelo Chagas; mas reconhêço que não deve sêr assim, porque ha o devêr de agir, concorrêr para a luz, sêr útil, communicar o enthusiasmo do bem e da justiça, falar aos homens nas bellas ideas e nos sentimentos generosos. "Vivre, c'est avancer", diz o Guy au nos seus versos, e o homem que se recolhe exclusivamente no interior do seu pensamento não póde dizer-se que realmente avance, em toda a plenitude do termo. Tudo isto eu sei, tudo isto me digo por vêzes a mim mesmo, mas o meu genio leva-me 
irresistivelmente a espalhar-me, disperdiçar-me, percorrêr tudo ao mesmo tempo, e a passar dias e dias desatientos, distrahidos, em que devaneio muito e não penso. Precisava de alguém que me obrigasse ao méthodo, que me fizesse por exemplo trabalhar de noite, coisa de que ainda não fui capaz, e que tanta pêrda me tem feito. A noite é exactamente o tempo livre por completo, aquelle que todos os trabalhadores da intelligencia aproveitam, o mais próprio para o recolhimento.... Desde muito novo tive sempre amigos que me dirigiam, me tratavam nos pequenos actos da vida e que commigo se aconselhavam nos importantes. Eu governava-os espiritualmente, e elles governavam-me materialmente a mim. No Collegio Militar o mais típico foi um rapaz Lusignan de Azevêdo. Era um anno ou dois mais adiantado do que eu. Dizia-me que aulas eu tinha nesse dia, mandava tratar das minhas coisas, lembrava-me as minhas obrigações a cada momento... Necessitava de que me fizessem isto para o trabalho intellectual, que me jungissem todos os dias como um boi ao meu arado, para que arasse a terra fecunda que planeáva revolvêr. Os boisinhos vão aos pares, minha Luisa. Dardeja o sol pela risonha esfera com crinas de oiro; e as abelhas, voejando, scintillam em redór dos animaes pacientes de fontes calmas. Os bois teem seu quê de augusto e de sagrado. A terra, quando luz escaldando, embriaga-me: sinto que só integrada nella sou completo e natural. Um homem que immensamente invejo é o Charles de Pommairols. Puro fidalgo antiquíssimo, dirigindo hoje as propriedades que são da sua estirpe desde o tempo das cruzadas. Quando trabalha no escritório vệ pela janella os seus homens a tratar dos seus campos. Ha-de lê-lo. E interessante toda a parte que intitulou $A$ Poesia da Propriedade. Lá conta como os avós lhe foram accrescentando o património.

"Comme de vaillants chefs et comme de bons rois...»

Quando começar a estudar a esthetica va-se exercitando a fazêr resumos, análises, apontamentos, em livros em branco ou em caderninhos de papel. Comece por umas folhinhas separadas que lhe mostrei outro dia em casa e que cheguei a embrulhar para irem para a sua, mas que ainda lá ficaram. Se fôr ao estrangeiro e visitar alguma cidade importante, aproveite instruir-se, deleitar-se e enriquecêr o espírito nos museus. Estude nos quadros e nas esculturas as ideas, as concepções, os costumes das época. Acostume-se a vêr a obra de arte não só como arte mas também como documento historico ou psicológico. Comparar o pintor classico David com o pintor romântico Delacroix corresponde a comparar uma tragedia classica com um drama romântico, quer dizer ainda uma concepção esthetica com uma outra concepção esthetica, reveladas em obras de differente naturêza; mas por outro lado comparar uma escultura grega antiga com uma escultura moderna (por ex. a Historia de Teixeira Lopes) equivale a comparar, já não uma concepção esthetica com outra, mas uma concepção da vida, da naturêza, do homem, com outra concepção do homem, da naturêza e da vida. Quanto a psicologia, compare Rembrand [sic] por ex. a Velasquez, e sentirá a differença de dois temperamentos de homem, de duas raças mesmo, - não falo agora de duas ideas, mas de duas criaturas de carne e osso. (Lerá Léailles, Le Génie dans VArt; Fromentin, Les Maîtres d'autrefois).

Ao principio poderá tudo isto parecêr-lhe um pouco maçador, mas juro-lhe que para o fim se apaixonará, e verá como é um estudo simples, elementar, bonito, fácil de comprehender como nenhum. Lidas as taes folhas que separei (questão de uma hora) começará pelo Taine $\left(l^{\circ}\right.$ prefacio da Histoire de la littérature anglaise, muito pequeno; $2 .^{\circ}$ Philosophie de VArt; $3 .^{\circ}$ Lafontaine et ses fables; $4 .^{\circ}$ Essais 
de critique et d'histoire, alguns ensaios). Seguirá com o Guyau (L'Art au point de une sociologique; Les Problèmes de l'esthetique contemporaine); Léailles (Le Génie dans l'Art); Mario Pilo (Lezione sul bello), etc. Ao mesmo tempo verá estampas, quadros, etc., e estudará depois os escritores portuguêses mais interessantes, como Camões, Herculano, Garrett, Castilho, Oliveira Martins, Anthero, etc. Gostava de que lêsse cêdo o Oliveira Martins, mas comparando-o ao francês Michelet e ao inglês Carlyle. Logo depois de conhecêr o Taine dar-lhe-ei um estudosinho de Moniz Barreto sobre $O$. Marcins, a seguir ao qual principiará com este $\left(\mathrm{l}^{\circ}\right.$ Camões, os Lusíadas $e$ a Renascença em Portugal; 2. História de Portugal; 3. ${ }^{\circ}$ Portugal contemporaneo; $4 .^{\circ}$ Os filhos de D. João I, etc.).

Minha Luchezinha do meu coração, verá que passar a nossa alma pelos bellos sentimentos expressos pelos bons artistas é um prazêr puríssimo, cheio, delicioso, que enche bem uma existência, e a melhor coisa que ha neste mundo depois de um santo amor como é o nosso. Lembre-se de que espero de si uma dedicação sem limites, um interesse infinito por mim nas mais pequeninas coisas, uma paixão lúcida e forte como o aço. Repare que me está prometiendo um ceu, e que a mais ligeira decepção agora seria uma terrível crueldade: queira sadsfazêr-me e conte commigo, minha Luisa. Vejo só um contratempo grave: as minhas condições materiaes. Não quero pensar nisso, minha Luisa, não quero pensar porque m'o prohibe...

Minha Luisa, minha Luisa de olhos fechados, a palpitar, estou fantasiando vagamente que lhe segredo coisas ternas... Minha pomba da minh'alma, ama-me muito, muito, muito: sê muito exigente com os sentimentos a a vida do teu Sergio, mas sê muixo boa para com elle; continua a sonhar que vives com elle e para elle, que lhe dedicas todos os momentos, que o acompanhas em todas as horas. Minha Luisa, minha mulherzinha, minha amante: quereria atirar todo o meu coração para o teu peito, como se atira uma braçada de flores frêscas para o regaço de uma donzella; crê que o teu noivo te ama de uma maneira singular e unica, extravagante talvêz, mas com certẹza muito bella: alguma coisa se ganha em sêr doido como eu sou. É possível que o meu amor tenha menos embriaguêz que outro qualquer, mas julgo que tem muito mais doçura. Em logar de um meio-dia será talvêz uma tarde deleitosa ou uma manhan rociada, - de que os orvalhos são, minha querida, as blandícias que fazes cair de cada frase que me dizes. Poderás amanhan fitar bem os meus olhos e vêr nelles reflectida a limpidêz do coração...

Minha Luisa, Luisazinha suave e clara como um ribeiro entre juncaes: se lhe falo no meu amor não é porque tema que o não conhêça; a alma da minha noiva sabe como eu amo, porque sente como a minha; vê que nada ha de mais puro, mais alado, mais luminoso e cantante. Sôam-me as suas palavras como umas cascatas, musicaes como ellas, como ellas frescas, todas emperladas como ellas são; e sempre, sempre, sempre devem ellas cair amorosamente para o meu peito que se extasia...

Adeus, Luisa; ame-me o mais que é possível amar. Que a vida do seu Sergio seja um poema inspirado pelo seu esforço, pelos seus cuidados, pela sua vontade perseverante, para que eu possa dizêr que foi a asa do amor que alimentou, fortaleceu, sustentou em mim a asa branca do pensamento. Adeus, até amanhan. Não se esquèça a minha adorada mulherzinha de que ninguem a poderia amar melhor do que o seu

Antonio Sergio 


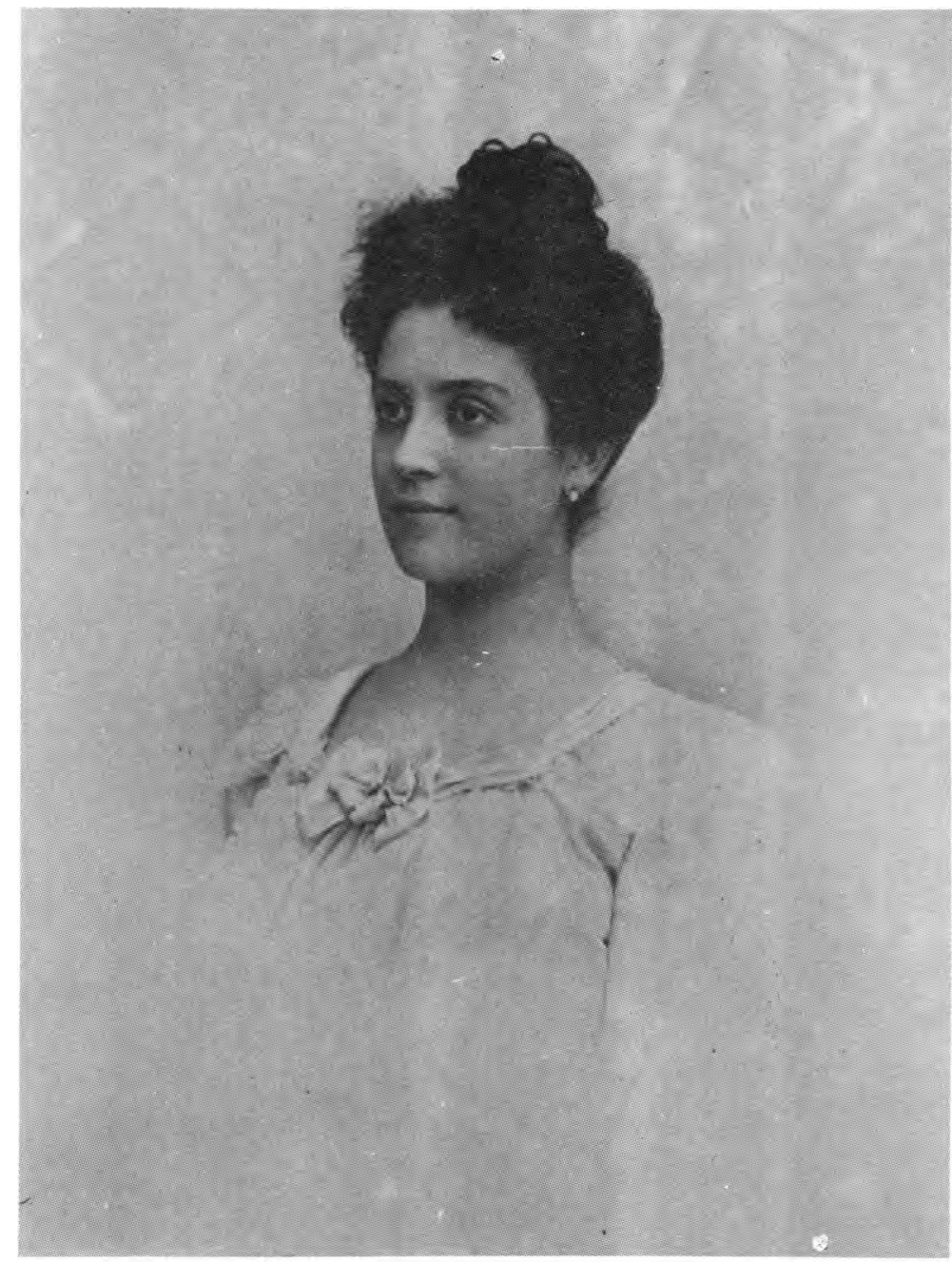

Pilar Sérgio de Sousa Silva, irmã de Antonio Sérgio (a quai casou, mais tarde, com o escultor João da Silva) 
(Página deixada propositadamente em branco) 
Minha boa e nobre irmanzinha: São onze e meia da noite, acabo de vir com a Pilar de casa dos Chagas, de quem nos fomos despedir. Não lhe escrevi mais hoje de dia para não demorar o rapaz e não complicar as coisas com a Pilar, que também lhe estava escrevendo, e com a minha Mãe, que andava atarefada.

A nossa conversa de hontem, fazendo-me entrar positiva, concreta, minuciosamente nas condições do futuro, deixou-me desanimado. Minha Luisa, se eu me fosse enllocar na dependencia de seu Pae havia de o pagar carissimo, e já a idea de qualquer dependencia d'esse género levanta em todas as gotas do meu sangue a mais viva repulsão. Dêvo-lhe muitos obsequios, porém obsequios que obrigam mas não rebaixam; ora, para nos podermos casar sem me ir pôr numa situação tristíssima, seria necessario cortar com elle, coisa que a minha Luch não deveria nem poderia fazêr. Nesta segunda ${ }^{\wedge}$ difficuldade não toquei directamente até hoje porque como vê é bem mais delicada que a outra; em todo caso está nella comprehendida quasi totalmente, porque, se eu fôsse abastado muito natural e razoavelmente os attritos diminuiriam. Repare bem numa coisa, meu amor: deve a Luisa sêr a primeira a não querer que o seu marido ficasse numa situação pouco livre, por assim dizêr, ou pouco altiva. Posso dizêr tranquilamente que falei a tempo. "A menos de um milagre não lhe vejo solução»: lembro-me bem de que foram estas as minhas palavras ao finalizar e resumir. «O amor dos homens é o amor da dignidade humana»: lembro-me também de que lhe repeti em tempo esta frase de um escritor; é no amor da minha dignidade que eu quero que faça consistir em grande parte o seu amor á minha pessoa. Não queira uma situação menos livre para o seu marido, percebêu? não queira. Foi por tudo isto que a minha lealdade lhe propos uma situação de expectativa que a Luisa não comprehendeu bem, pois a interpretou como pesando-me a nossa situação actual. Todos estes avisos foram por attenção $a s i$, porque eu por mim, considerado como independente da minha querida Luch, nada tenho a perdêr em to(las as situações possíveis. Peço-lhe agora só isto: seja a Luisa a primeira a repelir a idea da minha dependencia.

Minha Luisa, olhe fríamente para estas coisas. Por amor de Deus não desate a apoquentar-se, quando não me dá meio de lhe falar seriamente. Se se mostra apoquentada continúo eternamente com medo de lhe falar, e vamos caminhando cegamente. $O$ que me contou sobre as intenções de seu Pae veio collocar-me as coisas numa subjugadôra evidencia e realidade. Espero que já não poderá suspeitar de que me "pesa» a situação actual, etc. Chegou oceasião de the pedir que falemos prosaicamente e friamente nas positivas realidades do nosso caso. Parece-me que já o podemos fazêr, porque a minha adorada Luisinha já não poderia agora fantasiar suspeitas que a desgostassem. Não é verdade?

Muito seu, muito dedicado, muito amante, e muito saudoso

A. S. 
Quartel, 27. 9 h da noite (Junho - 09)

Ainda bem, minha pequenina, que foi tão intelligente e tão lúcida. Passei toda a noite acordado e malquieto, com mểdo que me não tivesse interpretado bem. O que eu fantasiei de coisas más que tivessem podido passar no seu espirito!

O dia de hontem foi muito triste. Por mais que fizesse não conseguia encaixar o meu sonho na R. Antonio Maria Cardoso. Como elle ficava amachucado, coitadito! Só conseguia ver seu $P$. na attitude em que o deparei na manhan da tipografia. Apreciei muito então a minha carreira militar, essencialmente aristocrática. $O$ militar póde sêr mais ou menos simpático ao seu superior, mas não depende de ninguém o seu pão. O empregado necessita de agradar ao seu patrão, que o póde despedir, deixando-o á fome; o comerciante necessita de agradar ao freguêz, que pode fugir-lhe e escolhêr outro caminho. Nada d'isso com o militar: se o castigarem injustamente, responde de cabeça alta, e reclama. Eu não sou nada altivo, vaidoso ou orgulhoso; mas até hoje não soffri a mais pequenina beliscadura, e a primeira que tivesse de soffrêr não sei que seria de mim. Adoecia com certêza. Tenho sido extraordinarissimamente feliz neste ponto. Só a idea da mais ligeira falta de attenção, que me visse obrigado a supportar, me faz mal aos nervos. Nunca se esquèça, Luisa, de que sendo eu extraordinariamente sensivel, uma insignificante arranhadura basta para me entristecêr e abatêr completamente. Hontem á noite estava tão desanimado que lhe não queria escrevêr. Foi por pensar que se magoaria se nada recebesse que lá me decidi afinal, com immensa repugnância. Já fica avisada: notando silencio, concisão, tristêza em mim, não se apoquente com isso, porque uma nuvem momentânea é o bastante para me ensombrar como um eclipse total. Por amor de Deus capacite-se bem do que lhe digo: quando não, obriga-me a forçar-me, disfarçar, fingir animações que não sinto, quando estiver sombrio, e esse esforço, como sabe, é bem mais penoso ainda. Deixe-me estar no meu naturăl. Não tem que se apoquentar, porque me deve já conhecêr o genio. É esperar, com paciencia e confiança, que passe o temporal. Elle passará, com mais ou menos tempo.

\section{Depois de procellosa tempestade \\ Escura noite e sibilante vento \\ Traz a manhan serena claridade, \\ Esperança de porto e salvamento.}

Já lá dizia o Horacio que o genero «poeta» era irritável...

Olhae como este nos perora,

Com quanta graça! Ei-lo contente...

Porque será que ainda agora

Principiou tristonhamente?

Veja a minha Luch o que é sêr tolo: depois de Camões e Horácio, impinjo-lhe... Antonio Sergio!

O que a minha Luch nã̃o póde calcular é como as suas serenas e sensatas palavras ao telefone me fizeram bem. Seja sempre assim, serena, confiante, lúcida, quando me vir entristecido. Não me faça nunca afogar em pouca água, repetindo uma frase que meu Pae me 
dizia muitas vêzes. Por mais triste, arisco, abstracto, arredio que me vir, não desanime nunca. Ás vezes também, sem alguma apoquentação, mas só por andar muito enfronhado em qualquer pensamento, metto-me dentro de mim mesmo, esquèço este mundo, e é conveniente que me não accordem do meu somnambulismo. Não escrêvo á família, e fujo dos amigos, os quaes, se são o França, o Chagas ou o Rego Botelho, que me conhecem, elles mesmos se affascam bondosamente, e se não importam do meu abandono, certos como estão de que eu voltarei finalmente. A Pilar também se affasta nesses dias, limitando-se a perguntar «se ando agora a fazêr sonêtos». Estes casos são inevitáveis em todos os homens de vida interior rica, e nada teem que fazêr espanto a uma pessoa intelligente. A minha Luch portanto ha-de acha-los evidentes, naturalíssimos. Não é isto? Não se admire nunca da variabilidade das minhas maneiras.

Não calcula como lhe estou grato, minha Luch, pela sua sensata resposta de hoje: como me pacificou, como me cirou um peso de cima, que contente -fiquei comsigo, que satisfeito! Trate-me sempre maternalmente quando me vir apoquentado, como eu a trato paternalmente a si. A nossa sensibilidade infantil exige isto, e é preciso que successivamente nos amemos com todos os amores. Tem de sêr minha irmanzinha, minha mãe, meu amigo, minha noiva, tudo isto conforme as circunstancias, não se esquèça. Seja muito complexa e muito rica, porque eu sou muito rico e muito complexo. Permitta-me que hoje lhe fale como um filho, para lhe falar talvêz amanhan como um irmão e depois de amanhan como um noivo. Tem que têr uma paciencia infinita para me aturar, e as minhas maluquices, e as minhas metamorfoses. Como eu a apreciei hoje, como eu lhe estou grato! Como gostei de que me tivesse comprehendido, me tivesse achado razão! Procure, tente sempre dar-me razão, entrar no meu ponto de vista, sêr justa commigo. Sirva-lhe sempre de modêlo o que se passou hoje; estou agora perfeitamente calmo e entrei apoquentadíssimo para o quartel.

Tomara-me nos Vargos, para vêr se me ponho absolutamente bem. A propósito: disse-me que o médico a mandava para o estrangeiro por causa do estomago. Vejo-a olheirenta, desconfio que terá realmente qualquer coisa. Peço-Ihe com todo o empenho que faça um exame médico rigoroso e se trate a valer, com muito cuidado. Siga regras de higiene, exercício ao ar livre, etc., tamo quanto puder. Aproveite o mais possivel para a saude a sua estada lá fóra. Prometto-lhe começar agora a fazêr o mesmo. A saude è um bem inapreciável, e os nervos actualmente resentem-se [sic] de tudo. Chamo-lhe muito seriamente a attenção para estas recommendações. Por minha parce, consagrarei a isto toda a estada nos Vargos.

Acabou-se-me o papel, mas ainda encontrei esta folha com o competente sobrescripto dentro de um livro. E o Dournie? Acabado? Depois do Brunetière, as folhas (que ainda lhe não mandei) e o prefacio do $1 .^{\circ}$ volume da Historia da litteratura inglesa, do Taine, para seguir com a Philosophie de VArt, etc., e o resto da obra esthefca do mesmo autor. No fim de Julho já poderá têr escrito o seu esumo sobre Taine, para o que basta lể com attenção a Philosophie de VArt. Como eu gostaria, minha Luisa, que se apaixonasse profundamente por estas coisas! Oxalá, meu amôrzinho, minha andorinha querida, minha companheira em tudo! Tem o exemplo da Mad. Bensaude, e a minha mulher ha-de sêr bem superior a ella em illustração e larguêza de espírito.

Não creio que lhe valha a pena lêr a biografia do Kropotkine que ella lhe emprestou. Vi lá uma bella maxima: nunca se deve lêr 
um livro qualquer sem obedecêr a um plano; antes de abrir uma obra devemos sabêr a que pergunta queremos que ella nos responda. $O$ plano da minha Luisa é estar ao facto das doutrinas estheticas. Não se perca agora com outras coisas. Procure tirar partido de tudo, das suas lições de canto, das conversas com artistas, das suas viagens, etc. Não se aprende só com o que se lê, mas também em grandissima parte com o que se vê, o que se ouve e o que se faz. Attenção sempre acordada no sentido do nosso fim. Encarar muitas vêzes o mundo como uma matéria de exploração intellectual. Para que serve o universo? perguntaram uma vêz ao sábio Ampère: «para dar pensamentos aos espiritos». Tenha fé de que ainda o estudo lhe será uma fonte de prazêres puríssimos. Estou agora a lembrar-me das mulheres de S. Mill, de Michelet, de Ibsen, de $M^{\mathrm{me}}$ Curie, Maeterlink, tantas outras...

Se fôr a Paris, far-lhe-ei um plano de visita ao Louvre: se o puder seguir, muito bem, se não, paciencia, nada de perdido. Segundo esse plano, estudará os pintores, não pelo seu mérito artístico intrínseco, mas como representantes das doutrinas e das correntes moraes e artísticas. Procurará lêr nos quadros os espíritos das épocas. Edade-Media, Renascença, Classicismo do tempo de Luis XIV, época de Luis XV, neo-classicismo da Revolução e do Imperio, Romantismo, Naturalismo, Realismo. Nas horas vagas percorra o Apollo de Salomão Reinach, e entretenha-se a vêr as figuras.

Adeus, minha Luisa, estão-me chamando não sei para quê. O seu Sergiosinho está abatido, mas confiante e calmo. Adeus. Uma grande saudade do muito e muito seu, que de si espera a maior das dedicações, a maior,

A. S.

Minha Luisazinha muito e muito amada:

Que diria agora o meu amor se a professora de linguas Miss Karp se lembrasse de ir dar lições de francês... aos socios de VAcadémie française, ao romancista Paul Bourget ou ao linguista Gaston Paris? Diria que era loucura, que as liçổes são para os ignorantes e não para os sabios, para a gente vulgar e não para as excepções. Ora fique sabendo que os moralistas vulgares escrevem para as criaturas vulgaríssimas, para aquellas que mais precisam de que alguém as moralize. Amanhan poderá encontrar um «preceito» absolutamente contrário ao de que me fala na sua carta, e serão ambos igualmente bons, com a differença de que um dos mestres tinha na sua idea ao escrevêr uma certa espécie de discipulos, emquanto o outro tinha outra... Voilà tout. Não ha regras absolutas, porque não ha duas coisas iguaes. Oiça os medicos: um doente deve comêr muito, outro pouco, um carne, outro legumes, um deve sêr muito activo, outro estar na cama quasi sempre. A educação que o pae do Stuart Mill deu ao filho teve maravilhosos resultados, e levou-o a um rigor intellectual extraordinário; mas se o rapaz fosse outro ensandecia com certêza. 
Um moralista pois que escreve para um grande público deve partir da realidade do maior numero: a maioria da humanidade é má; portanto devem-nos ensinar a defendermo-nos d'ella; não sejamos ingénuos, a Luisa sabe, por experiencia própria, em que pavorosos enganos pode cair uma rapariga que não sabe ainda conhecêr os homens. As raposas abundam; já o Lafontaine bem avisa...

Le corbeau, honteux et con jus,

Jura, mais un peu tard, qu'on ne l'y prendrait plus.

Ora, a maioria dos rapazes tem tido varios namoros ou varios flirts; das boas palavras das raparigas tiram menos satisfação intima do que vaidade; todos se intumescem; gabarolam, contam. Depois, para o amador profissional tudo vae na conquista; uma vểz obtida uma certa ternura, já não ha nada a esperar, já não tem graça, passa-se a outra...

Concluindo, em grosso, (grosso modo, para falar latim), em geral, o preceito do seu... moralista é de primeira ordem; concordo absolutamente. Mesmo para a grande maioria dos já casados é muito bom, porque é raríssimo que se obtenha aquella identificação absoluta que quasi todos nem mesmo se pode dizêr que cheguem a desejar, porque a não chegam a percebër ou a conceber. $A$ maioria das esposas são o que eu lhe tenho já dito que são: e visto que os maridos as consideram subalternas, e subalternas as conservam, é boa tactica da parte d'ellas o conservar um certo ascendente neste ponto. Uma mulher deve sêr tanto mais cuidadosa e reservada neste ponto quanto vir que só pela paixão consegue prendêr o seu marido; e visto que o marido se lhe não prende pelos seus trabalhos, pela sua vida, pela sua ideação, pelos seus sonhos de ambição e de gloria, visto que em tudo isto a maioria das mulheres não são as companheiras do seu marido, seria tolice o não tê-los submettidos por outro lado, o não tomar, em outro campo, a desforra da inferioridade em que as collocam...

$\mathbf{E}$ verdade que os... «os moralistas» para a maioria, quando falam aos maridos, lá teem contra-receitas, outras tácticas, outras habilidades para oppôr victoriosamente ás habilidades femininas... Todas estas coisas, Luchezinha do meu coração, teem duas faces... Veja a fábula do Lafontaine em que lhe já falei. Ella ensina os corvos a precatar-se contra as astúcias da raposa; mas ensina também ás raposas como é que os corvos caém, como se apanham bellos queijos... Tudo é duplo, minha Luisa, tudo é duplo. Homo duplex, vá lá mais de latinório. Tudo é duplo. Nos assaltos das praças ha minas e contra-minas. Quando 1er cavalheiros que dão conselhos às meninas, será bom lêr também os que aconselham os rapazes, para completar o seu sabêr com o dos antidotos dos venenos...

Se quizer que lhe fale sério e a seu respeito, meu amor, dir-lhe-ei que faça como intendêr, é-me indifferente a apparenda ou o palavriado, contanto que a realidade se mantenha o que já era. Ame-me immensamente, e fale-me com frieza se intendêr que isso é bom. Se a minha Luisa pensar meio minuto, ha-de comprehender que eu tinha o devêr de lhe respondêr como respondo; e se tiver boa memória, ha-de recordar-se de que logo na $2 .^{a}$ ou $3 .^{a}$ carta eu lhe disse que não tinha empenho em que nos namorássemos, mas sim em que nos conhecêssemos. E parece-me que está dito tudo. Em este assumpto posso andar risonho e tranquillo, porque desde o principio tratei logo de lhe garantir toda a liberdade, de lhe dar todas as vantagens, de tirar das suas cartas o mínimo peso, a mínima difficuldade, o mínimo 
compromisso. A sua união commigo ha-de sêr a verdadeira união livre, absolutamente racional e voluntária. Sou $e u$ que defendo furiosamente a sua liberdade e a sua dignidade perante mim. A meus olhos a Luisa não pode fazêr coisas que a abaixem, porque eu não deixaria. Ora diga-me se é isto o que lhe agrada.

Notei com alegria que nos vamos comprehendendo muito bem. Agradeço-lhe profundamente os seus sonhos de gloria para a minha pessoa, mas deixe-me dizêr-lhe uma coisa. Ha a gloria barulhenta, vistosa, universal, a gloria dos escritores e artistas populares, a dos politicos, a dos oradores; e ha a gloria que consiste no alto aprêço de uma minoria escolhida, de um escol. Compare o Béranger, cujas canções toda a gente cantou no seu tempo, com o Leconte de Lisle, que só meia-duzia lê; o João de Deus, que vae têr uma estatua, com o Anthero, que a não terá nunca, apesar da meia-duzia de admiradores enthusiastas; compare o Vigny, que ninguem lê, com o Musset, que todos lêem, - o pobre Vigny, de quem uma senhora como a M.me Bensaude ousa dizêr que nada presta a não sêr o Cachet rouge ( ? a propósito, vá relêr o Mont des Oliviers!) — Ora, minha bem amada, eu nunca poderei têr uma gloria retumbante, nunca o meu nome será conhecido nas ruas, como o do Alpoim, ou nas salas, como o do Julio Dantas. Il Pensieroso, ou a Solidariedade nunca terão a centésima parte dos leitores que lêem as Rosas de todo o anno. Il Pensieroso não é melhor, mas é de outra especie, como os trêvos de quatro folhas não são mais bellos, mas são mais raros. Olhe, minha Luisa, um escritor, como o Lopes Mendonça, falou-me na Solidariedade e na Flôr campestre: elogiou-me lisonjeiramente a forma, mas vi que não comprehendêra nada, completamente nada das ideas, o que se chama nada...

Se chama «gloria» o sêr-se conhecido, o sêr apreciado e incensado por muita gente, eu nunca terei a gloria, em vida pelo menos. Porem talvêz consiga o impôr-me ao respeito e admiração da élite intellectual do meu pais, se tiver a sorte de lhe conseguir alguma attenção. Para isso preciso de vontade, tempo, socêgo de espirito, e incentivo da sua parte.

Espero que me não faltará nunca esse incentivo, meu amôrzinho querido. Está hoje um bello dia de sol, sinto-me claro também por dentro, e com uma grande sêde de ter commigo a Luchezinha, - a minha noivasinha que se mostraria muito reservada, coitadita, - porque assim opina o moralista... Coitada da minha Luch! viu-me melancólico estes dias, e julga sêr falta de reservas... Coitada da minha Luch!...

Por esse andar, tem o Brunetière acabado. Entretive-me a folhear hoje de manhan o livro de educação em que me mandou a carta de hontem. Encontrei isto: «... La lecture sera tout autrement féconde si, avant de tourner les pages, vous vous êtes proposé un but et comme un plaude de travail... Les livres n'ouvrent complètement leurs trésors qu'aux lecteurs qui les consultent avec une sorte de parti pris: celui d'y trouver une réponse a des questions précises, l'éclaircissement d'une vérité qu'on a préalablement entrevue». Por isso a minha pomba vae fazêr o plano de escrevêr um Ensaio sobre as doutrinas estheticas $v$ cntemporaneas. Esse ensaio escusa de sêr crítico: basta que seja historico, um resumo, um compendio, urna descripção analítica. Simples trabalho de estudar e resumir. Fará sobre o Taine, o Guyau, etc., sobre os esthetas contemporáneos, o que féz no seu collegio sobre Renan a filha de M.me Bensaude. Basta mesmo que reúna agora algumas notas, para fazêr o trabalho mais tarde, sob as minhas vistas. 
Não lhe pude escrever hontem, minha adorada cordeirinha, vou explicar porquê. $O$ pobre Chagas já tinha licença do médico para sair. Estava precisado de que eu o acompanhasse, e por isso fui lá a casa, saimos juntos, jantei com elle e conversámos durante a noite. Entretive-o falando-lhe de coisas gregas, do teatro de Eschylo, dos diálogos de Platão, da vida atheniense, da morte de Sócrates, da escultura de Phidias. E a minha Luch, entretanto? Minha Luisa, queria têr-te ao pé de mim, beijar-te as mãosinhas, meu amor. Estou a vêr a tua boquita a dizêr: «meu pequenino...»

$\mathrm{E}$ melhor escrevêr para os Vargos em dias determinados, 2. as e 6.as, por exemplo, para eu mesmo ir ao correio. Como conhecem a letra do França, nada mais natural fazerem-me perguntas, taes como: que diz elle? e o Chagas? etc. A propósito, mais uma vêz lhe peço que não ande a medir as meiguices que lhe escrêvo; é possivel que tenhamos mais que dizêr do que meiguices, e mesmo as frases amorosas, repetidas, tornam-se habituaes, mecânicas, perdem a vida, ficam coisas tão convencionaes e insignificativas como o Ill.mo e Ex.mo Senhor que escrevemos a toda gente. Não deixemos adormecer a alma ao som de cantigas bellas... Por tudo lhe peço, minha Luisa, não caia na puerilidade de avaliar o meu amor pela ternura das minhas frases. A maioria da gente habitua-se a repetir coisas amorosas como muitos rezam as Avè-Marias: mecanicamente, a pensar noutra coisa... As palavras são para alguns momentos: o sentir e o pensar é que são para sempre. Veja bem, minha Luisa, abra bem os olhos: habitue-se a querêr só a sólida realidade, o que e sério, verdadeiro e natural. Não acredite no fervor religioso das mulheres que balbuciam orações emquanto reparam no chapéu da visinha que chegou a Igreja... Bastaria eu suspeitar que avaliava a minha dedicação pelas frases meigas que lhe dissesse, para logo tomar odio a essas frases, - e para logo desanimar a seu respeito.

9 da noite.

Ah, minha Luisa, eu bem percebi, eu bem vi que não tinha lido em moralista nenhum. Faça o que quizer, mas seja muito sensata e muito verdadeira com sigo mesma. Não lhe levo a mal a invençãozinha do moralista, e seria capaz de parecêr tomar a sério, mas [sic].

10 e meia.

O Moraes Carvalho, passando por aqui lembrou-se de entrar e dizêr-me «duas palavras». As duas palavras d'elle nunca demoram menos de hora e meia. Adeus, minha Luisa, até amanhan.

Não sei como, vim encontrar a carta cheia de nódoas. Perdoe, não tenho tempo nem papel para escrevêr outra. Muitas saudades do seu

A. S.

2 de Julho, 9 da manhan. (- 09)

Imagina, minha Luisa, que mal chegámos hontem á noite ao Guarda-mór, onde estamos alojados, começa a pobre Mathilde com uma dor que a levou a gritar como uma desesperada até agora, em que socegou depois de umas picadas de morfina que o medico lhe ministrou. Estão deitadas, desde ha poucos minutos, a Pilar e a minha Mãe; e eu, todo de branco, á luz de um ceu soberbo, ouvindo rumo- 
rejar os patos e a passarada, comecei a escrevêr ao meu amor. $\mathbf{E}$ a proposito de branco, sabe acaso a minha noiva que as tancareiras de Macau diziam que $S i$-an tinha o coração branco como o fato que vestia? Si-an, Luchezinha, significa Quatro-olhos, homem de lunêtas, e era 0 appelido que me davam por ser o único do navio que as usava.

Durante o comboio vim entretido com os mimos da Pilar, que me «fazia amor», segundo a sua frase; e só ao chegar aqui, á casa de estar, senti verdadeiramente saudades tuas. Intenda-se: o que se chama sentir saudades, fundas, de rasgar o peito a uma criatura; e (talvêz aches curioso) e de tudo o candieiro, o candieirinho de petróleo da mêsa, o que mais se associa no meu espírito à tua imagem. Estou convencido de que é porque ainda não vi a sala, onde cantavas a inhumaine, ou o croquet, onde liamos o inglês e o Prudhomme... Que saudade, minha rola, que saudade! Vê tu esta sina: foi nos Vargos, ha uns dez anos, que tive a primeira impressão da Natureza e da terra; para os Vargos tenho vindo lenificar uma ou duas crises cruéis da minha vida; nos Vargos, meu amor, passei comtigo um mês magnífico... Só tenho pena, meu amor, que cá estivesses uma vêz sem eu cá estar, - e ainda assim se cumpre a sina de têr sempre, e sempre, uma nuvenzinha triste no meu ceu.

A minha ultima carta, querida Luisa, foi uma pequenina brincadeira encoberta que não interpretaste muito bem. Encoberta, porque não quiz respondêr a brincar claramente, quando seriamente me falavas; e brincadeira, apesar d'isso, vou agora explicar porquê. Se te respondesse completamente a sério só poderia dizêr que os teus receios eram injustos para commigo, que eu era sufficientemente digno para recebêr os teus carinhos sem os interpretar baixamente, etc. Ora isto tinha dois inconvenientes: $10^{\circ} 0$ parecêr que me offendêra; 2. ${ }^{\circ}$ parecêr que o que eu desejava era ir continuando a lograr as caricias da minha dama... Portanto, quanto ao primeiro ponto, convinha fazêr-te sentir, brincando, que os teus receios não eram próprios ou fundados numa Luisa e num Sergio, como as lições de francês fariam dó dadas a um Bourget ou a um Paris; e quanto ao segundo ponto, era preciso afastar em absoluto a verosimilhança de tal hipótese, o que seria bem difficil se eu tomasse muito a sério a tua injustiça. Relê a carta, minha Luisa, e dize se é ou não uma obra de sensatêz. Convencêr-te-ás de outra coisa, e é que tendo-te eu dito que eras, ou antes, tendo-te implicitamente comparado, como mulher, ao que é um Bourget como escritor, não veio a proposito respondêr-me com certo entono "que me és igual em tudo», etc., como se eu jamais te tivesse mostrado a convicção de que te era superior, ou em intelligencia, ou em sensatêz, ou em dignidade, etc. Tenho-te dado as maximas honras, tive até às vêzes exaggêros talvêz nalguns cuidados; e nas pequeninas coisas em que por acaso, e apesar da tua frase, me não és igual, faço quanto posso para te elevar, educar, instruir, e convencêr-te quanto possível de que tens a capacidade e a intelligencia necessárias. Desde o princípio te quiz dar a consciência de que te punha 0 mais alto possível; tenho humilhado a teus olhos os meus talentos, desviando a conversa quando pretendes elogiar-me; e até por minha vontade serias muito mais instruída do que eu em certos campos, já que outros te são vedados. Quando te conto de algumas homenagens que recebo, é para te dar alegria e não para fazêr que me admires, ou para me elevar no teu conceito. $\mathbf{E}$ ainda para têr o prazêr de compartilhar comtigo, minha querida, como se já diante de todos nos fossem communs as honras e os trabalhos. Nunca andei atrás de glorias ou de renomes; e se alguma alcançasse d'ora em diante, alegrar-me-ia a idea de que ainda ella te poderia dar honra 


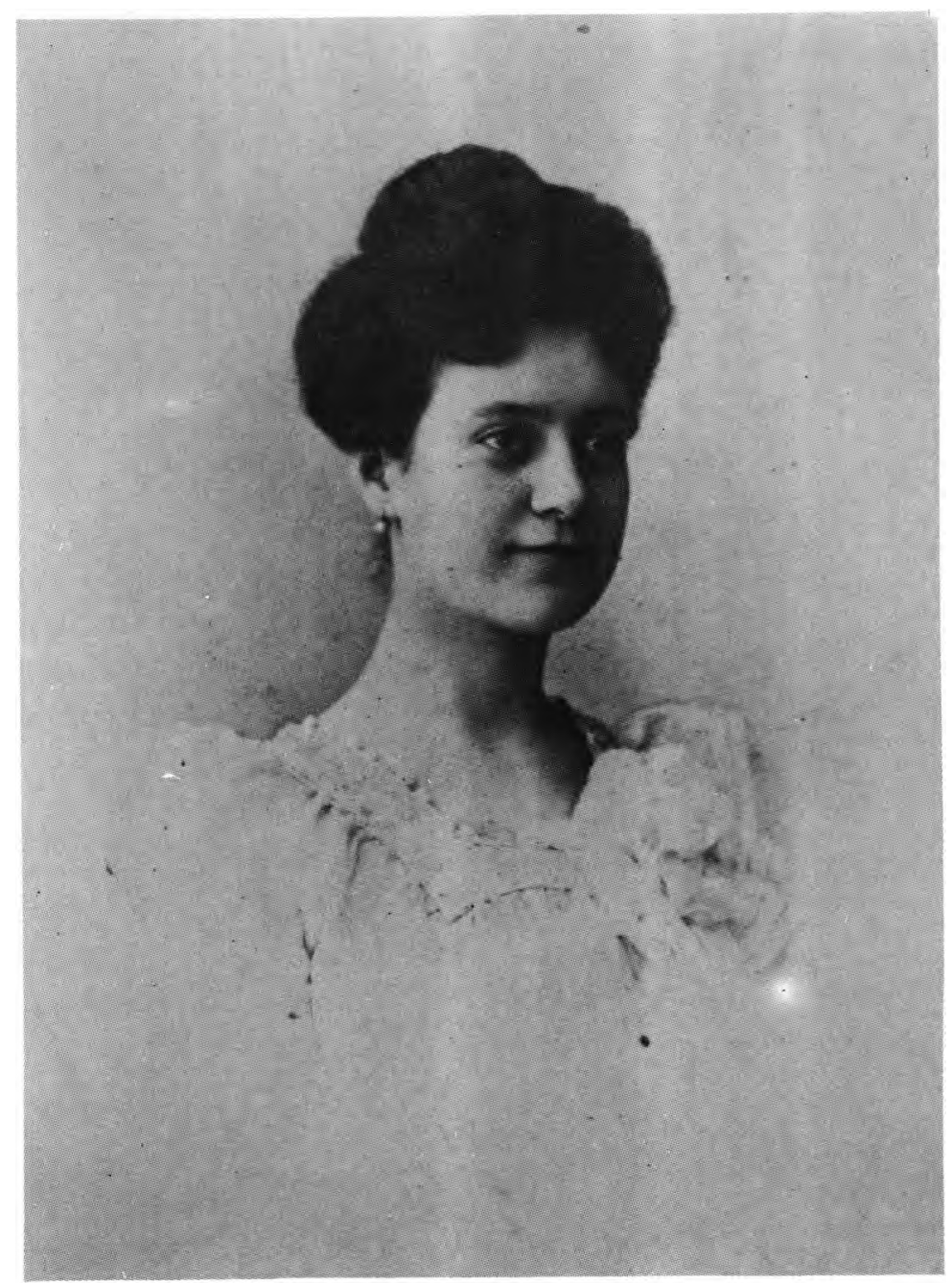

Matilde Sérgio de Sousa Cisneiros de Faria, irmã de Antonio Sérgio 
(Página deixada propositadamente em branco) 
a ti. Perdôe o tratamento, vou seguir já como de costume., Nunca se mostre orgulhosa commigo, Luisinha, pode têr toda a certeza de que lhe não dou razões para isso. Não desço á mesquinhez de me preoccupar com a minha personalidade perante qualquer dama, muito menos para comsigo. Diga-me se ficou convencida d'isto, e se está disposta a procedêr assim.

Quanto ás minhas severidades, de que fala, são ellas somente para a hipocrisia, para a falsidade, para as astucias femininas, sempre que ellas se me querem impôr como prata de lei. De resto, diante dos homens defendo, desculpo todas as mulheres, mesmo as de mais baixa esfera. O caso da prima Ruth foi o seguinte, que nada tem de mau, claro está, mas que a tornava incompativel commigo. (Comprehende naturalmente que só a si lh'ó contaria). Houve uma época em que ella me escrevia para a Escola Naval. Todas essas cartas eu rasgava e ia deitar eu mesmo ao rio, ou queimava em casa no meu laboratório. Pois convenceu-se ella (porquê?...) de que eu as dava a lêr à Mathilde, para depois procedêr como esta me aconselhasse (!!!). Pois negando-lhe eu o caso, respondeu-me que não acreditava, sem dizêr porquê, acho que devêra essa descoberta á sua «intuição», de que se gabava e gaba muito. Essas cartas, de resto, não eram cartas de amor, porque bem posso dizêr que jamais me escreveu de tal qualidade; não passavam de confidencias ligeiras a uma pessoa amiga. E aquelle facto, junto a outros semelhantes ou desemelhantes, fez-me desanimar profundamente da resolução que deliberadamente tomára em vista das circunstâncias. A quebra trouxe-me mêses de um remorso horroroso, pelo qual ainda tentei deixar-me vencêr, mas em vão. E aqui tem como o caso foi. Estou certo de que me dará razão.

Minha companheira querida, julgo que o assumpto por mim está esgotado, mas quando me respondểr a esta faça ainda as observações que julgar convenientes. Que tem feito o meu amor? Seria tolice estar-lhe a dizêr como, e quantas vêzes me lembro de si e tenho saudades do anno passado. Desisto de falar nisso porque seria um nunca acabar. Tem lido, pintado, ido ao atelier? Conte-me as suas impressões, se estiver para isso disposta. O Brunetière continuou a interessa-la? Intreter-se-á talvêz mais com o Taine, apesar de a forma sêr menos oratória. A respeito da minha pessoa, digo-lhe que neste momento me julgo um incapaz, parecendo-me que as Rimas e o Anther $o$ foram dois acasos felizes que não voltarão: não sei ainda qual é a minha vocação verdadeira. Quereria ao mesmo tempo fazêr qualquer modesto ensaio crítico e achar ou antes architectar uma obrasinha mais longa e verdadeiramente nova em poesia. Creio entretanto que o meu genio, como o meu gosto, me levam para pequenas peças bem sólidas, concisas, perfeitas, á Heredia. Mas neste caso gostaria de fazêr convergir todas as poesias num conjunto perfeitamente unido, como succede com os sonetos dos Navegadores: para isso seria preciso fixar um plano e escolher de vêz o assumpto a que me fosse inspirar, como com os ditos Navegadores succede. $E$ de que especie seria esse assumpto? Filosófico, moral, histórico, lendário, religioso? Não sei se me fiz bem comprehender: desconfio que em vêz de um só poema me seria preferível compor vários pequenos poemas ligados por uma mesma intenção geral, a qual intenção poderia sêr uma idea filosófica, ou uma aspiração moral, ou o carácter de uma época histórica, ou a representação poetica de qualquer concepção religiosa, etc. Antes de me metter a um caminho, todos os outros me chamam ao mesmo tempo. Por outro lado, teem-me elogiado muito as aptidões críticas; mas a crítica exige um trabalho de erudição incompativel com a minha profissão de marinheiro e com a 
escassêz dos meus recursos e, dentro em breve, do meu tempo. Só para estudar a doença do Camillo, teve o Paulo Osorio que gastar para cima de uma centena de mil reis em livros, afóra outros livros áe medicina que leu nas bibliotecas. O genero de vida d'elle é-lhe favorável, tem muito mais recursos, etc., e mais força de vontade também, muito mais. Não me queixo só das circunstancias, mas de mim principalmente: sou tão vil que ainda não consegui habituar-me a trabalhar de noite. Sêr-me-á fácil tendo companheira, em casando com a minha Luch. O curioso é que é precisamente a variedade das minhas aptidões que me traz perplexo. Sou uma cabeça equilibrada de mais: em vêz de mil pequenos talentos preferia têr um só grande talento. Já se não combateriam em mim faculdades cujos desenvolvimentos se excluem. Paciência. O que o berço dá a tumba o leva, diz o ditado.

11 da noite. Boa noite, minha Luisa. Não tenha mais frases orgulhosas. Fazem-me frio. Dão-me a impressão de que é outra pessoa, de que já não é uma commigo. Interessemo-nos infinitamente um pelo outro, a todos os momentos da vida inteira, sem preoccupações nem temores sobre a nossa personalidade.

A Mathilde já não tem a dôr, mas está abatida e de cama. A Pilar manda-lhe muitas saudades. E eu, que lhe hei-de eu mandar? Não digo um grande beijo para que se não arrependa de me têr dado confiança para isso. E entretanto esse beijo seria, comforme a sua expressão, «infantil». «Em verdade vos digo que quem se não fizer pequenino como estes são pequeninos não encontrará no reino do ceu». Não me lembro bem como são as palavras textuaes de S. Matteus. Isso compete à minha Luch, que é uma Doutora da Igreja. Coitada da minha Luch, eu ainda por cima a troçar d'ella? Saudades da Pilar. Deixe-me dizêr-lhe que desde que a Luisa lhe escreveu aquella carta, não faço segrêdo com ella: sabe como nos escrevemos, etc., e ella mesma me acompanhará ao correio, ou me irá buscar as suas ás terças e sabbados. Adeus.

Antonio Sergio

\section{CARTA DE LUISA STEPHANIA A ANTÓNIO SÉRGIO}

\section{Meu Sergiosinho}

Sexta feira 2 de Julho (1909)

Recebe esta carta mais cedo do que espera, mas é que fiquei a pensar que não havendo correio aos domingos, podia acontecer ficar esta presa até segunda feira, e o meu pequenino ter um desapontamento. Assim....* -lhe só mais cedo do que esperava e isso não é de todo máo.

Não calcula a impressão que tive hontem ao ver partir o comboyo, parecia que ia n'elle um pedaço da minha alma, via-o partir conchegado no meio dos seus queridos, só eu ficara, sósinha, sem ninguem que me consolasse... e n'aquella tarde alegre de sol senti

\footnotetext{
* [Ilegível]
} 
um frio muito grande. A partida hontem, trouxe-me á ideia outra mais longa, mais dolorosa, e já de antemão lhe provei a angustia e 0 amargor...

Meu pequenino, diga, foi boa a viagem? Chegaram bem?

Vim para casa, fui estudar, vou-me interessando cada vez mais; para o que concorre sem duvida, a lembrança de que lhe dou prazer, e que esse estudo agora, ha de servir muito para a nossa vida mais tarde. Dá-me a ideia de que estou tratando do nosso «ninho». E é n'este trabalho lento, — pecit à petit — d'educaçâo e identificação que está a base da nossa felicidade futura. A minha memoria está "enferrujadíssima», será preciso muita paciencia para a pôr em aeção. Desanimo quando, depois de ter lido com toda a attenção qualquer cousa que desejo fixar, vejo que pouco ficou. Comprehendo que seja falta cL'hábito, pois ha annos que não the dou o mais pequeno exercício. Que de tempo desperdiçado, que pena me faz! Se a Miss tivesse sido oucro genero de pessoa, como poderia estar adiantada! O que vale é que «it is never too late to mend», e agora nós dois, vamos recuperar o perdido. Estou-lhe muito grata, meu Sergiosinho, por todo o seu interesse e paciencia. Sabe que a filha de M.mti Bensaude é «bachelier ès lettres, ès sciences»? Fez o seu exame agora. Durou 19 dias, calcule. Parece que na Suissa é costume em logar dos exames annuaes, fazerem só no ultima anno da escola o exame final, que é a recapitulação de tudo quanto aprenderam, desde o principio. É muito intelligente, aquella pequena e muito instruida, segundo parece, sólidamente instruida. Desde creacinha, foi sempre dirigida n'uma mesma orientação, sem interrupções, com segurança e criterio. E queria o meu Sergio comparar-me a ella!!... Eu que que [sic] nunca tive direcção de especie alguma, ninguem que se occupasse da minha educação; só tres annos interrompidos estive no collegio, depois vim para casa, nunca me occupei senão do estudo das linguas nada que me educasse e formasse a intelligencia; nenhuma convivência intellectual, nada, nada. E eu sempre tive tanta sede de aprender! Que pena não me terem aproveitado! O pouco que sei aprendi sosinha. Que de vezes eu sonhei ter uma pessoa verdadeiramente superior que me dirigisse n'um plano de estudos! Realisei agora este sonho e não imagina que grande satisfação tenho n'isso! Até isto N. S. me fez! Quem sabe se os nossos sonhos não são como um pressentimento que nos dá a Providencia, do que ha de ser um dia a nossa vida. Como que uma preparação do que ha de vir. Agora por sonhos: tantas vezes penso no nosso futuro (n'este nosso refiro-me ao seu). Nunca esperei para si uma Gloria retumbante e vistosa, o vulgo nunca o poderá comprehender, por isso lhe serão negados os applausos da maioria, mas quanto mais consoladora e digna de apreço é a admiração da élite, dos verdadeiros intellectuaes? Já o estou a ver na nossa casa, longe do bulicio do mundo, já consagrado, recebendo paternal e bondosamente os admiradores e enthusiasías que lhe vêem render os seus preitos e homenagens... Será então uma pessoa muito importante, de todo o respeito e consideração, eu também "hei de me pôr á altura», mas depois quando estivermos sós os dois, havemos de brincar e rir como agora nos tempos em que eu era a Lueh e o Sergio o «meu pequenino». Apezar de todas as glorias e de todas as cousas havemos de ser sempre os mesmos noivinhos muito amiguinhos, muito juntinhos em tudo, não é assim? Muitas vezes penso, a que ramo se dedicará. Ao 1er esta concepção d'Augustin Thierry sobre a Historia, lembrei me de si: «J'avais l'ambition de faire de l'art en même temps que de la science, de faire du drame à l'aide de matériaux fournis par une éruditon sincère et scrupuleuse». $O$ Doumic acrescenta: «C'est-à-dire résurection 
vivante mais exacte du passé, oeuvre d'art et de science, i'imagination et la critique se complétant pour produire dans l'esprit le sentiment de la vérité historique». Que bem o meu Sergio estaria n'esses casos! Que programma de trabalho tão interessante está ahi apon;ado, não acha?

A respeito da casa cá de baixo, não lhe fez grande impressão, não é verdade? A mim não me pareceu mal. Também tem communicação por dentro, para a.............*

Que grande poder tem a imaginação! quando lá estive já estava a ver tudo mobilado, arranjado á nossa moda. Enquanto o Bordallo Pinheiro nos mostrava sollicito os seus «poly-chromos» estava eu vendo no logar d'elles cousas bem mais bonitas!!...

3 de Julho

Meu queridinho estou doida de contente. Imagina que me parece que sempre vou uns diasinhos aos Vargos!!! O meu Pai hontem estava mjo bem disposto e disse me: «Porque não vaes tu estes dias que eu estou fóra, . $^{\text {a }}$ os Vargos?» Eu respondi que era muito provável que o Antonio Sergio lá estivesse também (não tive coragem de dizer positivamente que estava!) pois sabia que havia pedido licença p. ${ }^{a}$ o mez de Julho, e portanto eu não podia ir conforme ao que o Papá me havia dito já. Elle então disse, «Faz-me pena deixar-te cá sósinha, lá sempre estás mais distrahida, levo-te quando fôr e deixo te na estação». Ainda me parece um sonho, não acredito sem me ver lá. Não dormi nada toda a noite a pensar n'istoü Meu Sergiosinho que bom, que bom!! Vamos a ver se se réalisa este sonho! Vou escrever á Ruth, para ella preparar a Tia Pilar. O peor é se é preciso incomodá-la! Estou com mJo medo que o Sud-Express não pare em Torres Novas e para irem ao Entroncamento não seria possivel é demasiado longe. N. Senhor arranja tudo!! Se fôr é no principio da proxima semana.

Adeus, meu Sergio, meu noivosinho, será verdade que m.to breve nos tornaremos a ver? Parece-me bom de mais!

Sua

Luch

3 de Julho, 2 da tarde. (09)

Sinto às vêzes uma tal onda de ternura, meu amor, uma vontade de a têr ao pé de mim, de que seja maternal commigo! Olhe, Luizinha, deixe-me fugir de pensar nisto, de lhe dizêr coisas d'estas; faz-me mal tudo que me torna mais sensível a sua ausência. Lembrando-me de que amanhan é domingo e estive para lhe não mandar hoje ainda, visto não havêr distribuição antes de segunda-feira. Em todo caso lá vae. Não se esquèça de que deve preparar-se a sêr um outro eu do seu Sergio, a minha providencia, o meu escudo. Não tenha um acto commigo que não seja um cuidado, uma palavra que não seja bôa. Nunca mais tenha dúvidas de qualidade alguma, não repare se lhe falo nisto ou naquillo, de maneiras meigas ou de maneiras sérias, certa de que no fundo a minha alma para si está sempre 
alerta e sempre amante. $O$ eu falar-lhe como a mim mesmo nos meus projectos, nas minhas dúvidas, em toda a minha vida interior, é uma prova de affecto bem maior que todas as palavras ternas. Diga-me se realmente vê que é assim mesmo, se sente isto. Queira-me muito, muito, muito, muito e esteja certa de que lh'o merếço. Mas se por infelicidade sentisse diminuir em si o amor um nadinha que fosse, não deveria deixar de m'o dizêr immediatamente. Verdade, verdade, verdade ,sempre verdade; é commigo o único processo bom. Ha pessoas que amam, por assim dizer exterior mente: eu só sei do que ha de mais interior e de mais íntimo. Adeus

\section{A. S.}

Pállida, crepuscular, anémica, gelada, A lua appareceu por entre a ramaria, Instillando em silencio a claridade fria Através uma trama obscura e complicada Onde se prende o canto e sonha a fantasia.

Silencio. Tudo dorme. A solidão descansa.

Nos troncos o luar varia o seu recorte,

$E$ a branca luz que sobe e um novo ramo alcança

Mede o tempo a corrêr, pesado na balança

Onde a vida se abaixa, onde se eleva a morte.

Como não calculo quando virá, estou sem sabêr, minha Luchezinha, se lhe devo escrevêr ou não. A sua carta veio enchêr-me de impaciência. Com a esperança da vinda tornou-se-me de todo insupportável a sua ausência. Oxalá não venha um desengano, porque seria agora bem cruel, e bem mais difficil a separação. Se somasse todos os instantes em que não tenho pensado em si desde que vim, não faziam mais de uns 5 minutos. $E$ que mais seria preciso para provar à minha Luch que a ama, que a amo, que a amo muito?

A pobre Mathilde tem continuado sempre com a tal dor: parece que é da passagem de areias, coitadita. A Pilar não tem saido por isto. Vou de dia para a Cerrada do Pôço, depois de jantar fico um pouco na varanda com a tia Pilar, e depois deito até ao repuxo, onde me conservo quanto posso. Não lhe descrêvo a scena, minha amada immensa amada, para não parecêr pretencioso. Basta dizêr-lhe que para as bandas da serra o horizonte, todo recortadinho pelas arvores, se conserva alaranjado até tarde; o fiosinho de agua vae cantando continuamente na sua sombra, - e todo o folhêdo, lá nos altos, vae murmurando o seu murmúrio. Fico para ali a fantasiar coisas várias, sempre entermeiádas e combinadas com a imagem da minha Luch. Não roda um carro que me não venha a esperança irracional de sêr 
ella que me chega. Cheguei até a julgar que me apparecia ali, feiticeiramente, a estendêr-me as mãosinhas e a sorrir. Depois a lua nasce, mesmo defronte do meu banco, de costas voltadas para o poente. Sóbe muito redondinha, toda branca, como a cara convalescente de um amigo, e toda tracejada por uma rêde de troncos pretos, de raminhos $e$ de folhas. Volto com a noite fechada, senco-me na varanda,... - e ainda tremo-assustadamente com cada carro que vem rodando. Estou cheio de mêdos, minha cordeira, dos inconvenientes, de qualquer coisa que faça desistir o seu Pae. Receio escrevêr-lhe, não vá a minha carta sêr encontrada e fazêr mudar as resoluções... A prima Ruth recebeu hoje a sua, e só pô-de lê-la depois do almoço. Estava eu na varanda com a tia e com a Pilar, quando ella chegou dizendo a nova. Como calcula eu estava impaciente e á espera. Tinha na mão um livro com estampas que continuei a folhear sem levantar os olhos. $E$ bem felizmente, porque senti que me fazia córado. Não houve mal, porque ninguem olhava para mim; ella, prima Ruth, continuava a lêr a carta...

Adeus, minha noivasinha do meu coração, minha^ ${ }^{\wedge}$ Luchezinha muito minha. Seria estúpido dizêr-lhe quanto estou anciôso pelo que isto dá. Receio mandar esta carta. Dá-me vontade de nem respirar, para que se não possa sentir que estou cá nos Vargos.

A. S.

\section{CARTA DE LUISA STEPHANIA A ANTÓNIO SÉRGIO}

5 de Julho (1909)

Que alegria me deu a sua carta querido noivosinho! Ainda bem que não esperou por hoje para a mandar. Já estava anciosa por noticias. Quando o leio, parece que o estou a ouvir, de maneira que me é uma grande consolação. O correio hoje chegou mais tarde, já passava das 9 H- Já uma vez quando recebi duas cartas suas, succedeu assim. Já havia perdido a esperança, já estava desanimada e ia discursando comigo mesma - «pour me faire entendre raison» - que era preciso ter juizo, não ser creança etc. etc. Mas apezar de toda a «eloquência» sentia-me muito desapontada; tinha ${ }^{\wedge}$ tanta sede de o ouvir! Meu pequenino, que boa cartinha escreveu á sua Luch, gosto tanto quando conversa assim commigo e me conta as suas cousas íntimas, assim sznto-me verdadeiramente a sua companheira; e não imagina como tomo a serio, a minha «importancia». Nem uma cousa que me diz, me passa, tudo fica muito gravadinho na lembrança e interessa-me tão profundamente. Não sei ainda o que faça a respeito d'esta carta, se a mande já hoje, ou se será cedo de mais, depois da que deveriam ter recebido hontem. Fiz confusão, quando me disse que escrevesse ás $2 .^{\text {as }}$ e 6.as, pensei que queria dizer que fizesse com que as recebesse n'sses dias, e por isso, receiosa de que, por ser domingo, houvesse demora $e$ não recebesse na segunda feira, escrevi p. $^{\text {a }}$ que recebesse no domingo. Como me disse hoje que ás terças e sabbados vão ao correio, receio que espere alguma cousa amanhã e tenha um desapontamento. Não sei o que será melhor!... 
Coitada da Tuca, que pena tenho d'ella, que grande aborrecimento, mas a que seria isso devido?

Tenho andado n'uma grande anciedade, por causa da incerteza de ir ou não aos Vargos agora. Depois d'este renascimento de esperança e a alegria que ella me causa, era cruel se afinal não fosse. Ao mesmo tempo parece-me uma cousa tão boa, tão boa que é demaziada felicidade. Tornei a fallar n'isso a meu Pai, e disse-lhe positivamente que o Sergio lá estava, tinha escrúpulos de não haver sido completamente franca. Elle ficou assim atrapalhado, nem disse que sim, nem que não. Oh meu Sergiosinho que bom seria estarmos uns diasinhos juntos, já nos podiamos affigurar que estavamos casados e que nunca mais nos separavamos. Que bom, que bom!

O Brunetière já está acabado já li as notas referentes a todos os que me indicou e algumas mais que me interessaram. Vou agora passar para as folhas sobre a esthetica em seguida para o Taine. Se fôr aos Vargos levo isso e também o Brunetière para o meu sabio fazer umas explicações. Levo também o Sully Prudhomme o Vigny e o Herédia para lermos juntos. Onde será a leitura este anno? Olhe, Sergiosinho, de manhã antes do almoço, era uma bella occasião de estarmos á vontade. Podiamos ir todos quatro para a Cerrada do Poço, a essa hora ainda as Senhoras (que afinal reduzem-se a uma(!!)) estão recolhidas; encher-nos-iamos para todo o dia um do outro, e já poderiamos estar com immenso juizo o resto do tempo!... Se ficarei ao pé de si á meza?!

Não tenho alma senão para pensar n'isto. Já puz tudo nas mãos de Deus. O meu livro de meditação diz que é preciso não desejarmos cousa alguma com exaggero, conservarmo-nos em paz no meio de tudo. Eu vou fazendo a diligencia de me unir á vontade de Deus e não querer senão o que Elle quizer, mas cá dentro está sempre uma cousa a pedir " $\mathrm{Oh}$ Jesusinho arrange isto que me dava tanto prazer!...» Vamos a ver se Elle me faz a vontade. Tem razão meu Sergio, «interessemo-nos infinitamente um pelo outro a todos os momentos da vida inteira, sem preoccupaçÕes nem temores sobre a nossa personalidade». Effectivamente cada um de nós deve abysmar-se completamente no outro a ponto de esquecer a sua individualidade. Perdoe á sua Luch as palavras orgulhosas, meu pequenino, ella já não torna a ter orgulho com sigo.

6 de Julho

Afinal pareceu-me melhor deixar ficar a carta para hoje. Pela que recebi esta manhã da Ruth, vejo que a Mathilde continua incommodada, coitadinha! Julguei que fosse uma cousa passageira e que já estivesse completamente bem, afinal ainda está doente. Deus permitta que melhore depressa, pobresinha! Hontem fomos depois do jantar ao Estoril, gosto immenso d'aquelle passeio à beira-mar. Como me lembro de si, Sergio, quando alguma cousa me impressiona de qualquer maneira! Aquella noute linda de luar aquella paz, aquelle silencio, recordavam-me intensamente o meu Sergio e uma saudade funda, funda, agarrou-se-me ao coração! Aquella mesma hora estaria provavelmente na varanda dos Vargos, talvez pensando em mim, quem sabe? Fomos visitar uma prima recentemente chegada de Shangae onde o marido era consul. Estão casados ha 7 annos e teem lá estado sempre. São felizes e muito amigos. Lembrei-me de nós dois, depois de 7 annos de casados, e procurei realisar a nossa vida então! Fui à M.me Bensaude que hoje não ficou extraordinariamente satisfeita comigo. Não estava disposta para cantar, lembrava-me todo o tempo dos Vargos — irei, não irei!... "Que j'aimerais savoir ce qui occupe ainsi vos pensées, dizia-me ella, si enfin vous 
vous décidiez que elle me ferait plaisir! Croyez-le, le jour ou j'apprendrai que vous avez fait votre choix, je serai vraiment heureuse, je ne puis pas penser q'une fille comme vous, ne se marie point». Que grande vontade tive de lhe dizer que podia começar a estar "vraiment heureuse»!...

Hontem esteve cá o Carlos Reis, que me fez immensa pena. Es Lá muito em baixo coitado! Impressionou me porque o vi muito scismatico e como se tivesse alguma preparada. Pobre homem, dá me a impressão que não tem ninguem que o ajude a levar a sua cruz. Disse-lhe muitas cousas, d'estas que nada remedeiam, claro está, mas sempre acalma um pouco quando se está muito amargurado o ver que alguém se interessa por nós, parecia tão agradecido, coitadito e começou a desabafar como quem já não podia mais guardar tudo para si. Tive pena de nada poder fazer por elle.

Meu Pai ainda nada me tornou a dizer a respeito dos Vargos nem quando partia. Disseram-me que o haviam ouvido dizer ao telephone que ia depois de amanhã, quinta feira. Sergiosinho, irei, não irei?!... Esta incerteza é insupportavel. Caso não possa ir - o que Deus não permitta! - mando carta na sexta p. ${ }^{a}$ chegar ahi no sabbado. Saudades á Pilar, diga-lhe que tenha muixo cuidado com a sua pessoa para ver se descansa e fica mais gordinha, estou desejosa de a ver e abraçar. Sergiosinho, irei? Adeus 3 horas da tarde.

Agora mesmo n'este instante recebo a querida cartinha d'hontem. Também está impaciente, meu amor. Que pena tenho de não poder dár-lhe uma resposta definit'va. Por vezes perco a esperança cie ir, pois parece-me bom de mais para se realisar. Ha de ser o que Deus quizer!

Adeus meu Sergiosinho, meu noivo querido, abraço-te em espirito e em espirito vou repetindo «tudo o que tenho a arder no coração e te não digo já, porque»... não posso!

Luch

\section{CARTA DE LUISA STEPHANIA A ANTÓNIO SÉRGIO}

7 de Julho (1909)

Sergiosinho: acaba agora mesmo de sahir d'aqui uma pobre mulher minha conhecida, que coitada deve ir fazer amanhã uma operação muito séria. Creio que é qualquer cousa de carácter espinhoso que ella tem na canna do nariz, um olho já está perdido e a operação é indispensável e immediata. Andou ella 8 mezes no hospital a fazer tratamento, e deixaram-n'a chegar áquelle ponto. Pobresinha! Veiò fazer-me as suas despedidas, e mais uma vez recomendou-me as filhas, que é tudo que ella tem no mundo. Não imagina quanto me impressionou esta conversa e quanto me edificou! Como ella estava serena, resignada, encavando a morte, pensando unicamente nas filhas, no futuro d'ellas. Que fé tão simples, tão nobre; que verdadeiro sentimento de religião n'aquella pobresinha que nem mesmo sabe 1er! Tive uma grande impressão do poder e bondade de Deus. Como «Elle se revela aos humildes e lhes faz sentir a força do seu braço»! 
«Oh minha Senhora, eu não tenho pena nenhuma de morrer, nem medo de cousa alguma que possa soffrer, só as minhas filhinhas me estão atravessadas!»... Quando vejo tantas desgraças que por todos os lados nos rodeiam, fico a pensar que direito temos nós de ser tão felizes, e chego a ter medo... Dá-me vontade de me agarrar a ti, meu Sergio, de maneira que nada, nada nos possa separar. Quereria calar o meu coração, com medo que os seus cantos d'amor possam despertar maguas escondidas... Meu Sergio, meu Sergio, gosemos da nossa felicidade, saibamos apreciá-la devidamente: Enquanto nos temos um ao outro, enchamo-nos um do outro:

Já que tudo por fim leva á morte

E com força o prazer agarrar

Sabe Deus quão depressa ha de a sorte

Um ao norte, outro ao sul atirar...

Ai África, África, nunca pensei que este nome havia de bulir-me tanto com o coração!

11 da noite.

Fui hoje ao atelier, as pequenas muito contentinhas, tudo muito bem, graças a Deus. Pediram-me licença para levarem a bandeira, (a sua bandeira) no proximo domingo. E a Ia Comunhão lá na freguesia: 30 meninas e 40 rapazes. Sahe tudo lá de casa em procissão, os rapazinhos veem buscar as meninas, acompanhados com a musica, e de lá vão todos p. ${ }^{\mathrm{a}}$ a egreja. depois do jantar

Fui também visitar a Prima Adelaide. Como de costume, f aliou-me em casamento, nas observações que pessoas conhecidas lhe teêm feito a esse respeito, e acrescentou logo: "Vi nos jornaes que havia partido para os Vargos, o Snr. Sergio de Sousa e pensei que a minha menina também lá estivesse». Eu, para dizer alguma cousa, respondi: «Como a minha Prima se interessa pelo Snr. Sergio.» - «Interesso-me sim, e muito, porque é elle o unico rapaz de quem eu a tenho ouvido fallar com enthusiasmo", e lembrou-me a tal phrase que me escapára no dia sua partida para Macau: «nunca esqueci a expressão d'aquellas palavras».

Ainda nada sei a respeito da partida do Papá. Quando voltávamos para casa, ouvi dizer ao Cisneiros Ferreira, (o primo da Tuca que está em Paris) que lhe perguntára quando elle partia, que ainda não sabia ao certo, que tivera de addiar por causa de negocios. Não imaginas, meu Sergio, os esforços que tenho de fazer para me conservar calma. Estou n'uma anciedade enorme, e tudo isto augmenta-me ainda extraordinariamente as saudades. O que eu daria por vê-lo, escar ao pé de si, um bocadinho, só um bocadinho!... Parece que tudo quanto digo não me allivia nada, e tenho o coração mJo apertado... Boa noute, meu amôr, estará ainda acordado?!

8-7-09 10 Vi da manhã

Estou vendo a varanda cheia de luz, as plantas, as cadeiras de palha, e o meu Sergio todo vestido de branco, sentado á espera que chamem para o almoço. Está certamente pensando na Luch, porque estou-lhe tão unida pelo pensamento, que é impossível que me não sinta junto de si. Sergiosinho, tenho vontade de chorar com saudades suas,..

A tarde Já estou com a «Philosophie de l'Art». As folhas da Esthetica interessaram muito assim como a Introdução da Litteratura ingleza. Que bonito é este estudo, como se encara a vida de uma maneira differente. Sabendo-se verr, tudo se torna interessante, que fonte 
de gozo se tornam para nós todas as cousas. Comprehendeu bem a phrase de S. ${ }^{\text {ta }}$ Catarina, porque com o espirito, dilata-se também o coração.

Nas folhas da Esthetica, encontrei um bocado que calha muito bem ao estado de expectativa em que se encontra o meu Poeta, do assumpto a que se ha de dedicar.

Dizia que o artista póde preparar a sua alma . $^{\mathrm{a}}$ as grandes concepções, formar o espirito e o coração, com altos pensamentos e sentimentos generosos, enriquecer a imaginação com imagens bellas, mas n'um dado momento a commoção que lhe dá um espectáculo da natureza, um livro de história um facto banal para todos, revela-lhe de repente o assumpto que convém ao seu genio. Está encontrada a obra d'arte que nasceu expontaneamente da inspiração, por uma especia de acaso providencial. - Espere portanto com paciencia, meu Sergiosinho, que ha de chegar esse momento, e quando menos esperar, depara-se-lhe de repente o caminho a seguir, aquillo para que foi destinado.

Em todo o caso vá já amontoando dados para a nossa grande obra. Tudo se approveita. Analyse os seus sentimentos, compare o presente com o passado, dedusa o futuro a ver se darão certo essas deducções...

9-7-09. Não sei porquê, hoje pensei que teria uma cartinha, esperei as 3 horas com impaciencia, mas não veio nada. Póde ser que venha logo ainda... ou amanhã! Recebi uma da Pilar; coitadinhas, que tempo tão apoquentado têem tido com a doença da Mathilde. Deus permitta que ella melhore depressa, que grande soffrimento tem tido! Mal sabe o Mene! Meu Sergiosinho, tomei uma resolução muito ajuizada. Não quero mais pensar na ida aos Vargos, vou fazer como se estivesse decidido não ir. Esta anciedade de nada aproveita e torna-me completamente inútil para tudo. Vou fazer um esforço - é preciso 1er juizo, saber supportar as contrariedades da vida. Meu Pai ainda não sabe quando poderá ir.

Se estará uma cartinha sua no quartel e o França não terá lá ido hoje?! N'esse caso só amanhã á tarde a poderei receber. Ainda falta tanto tempo!!

Como terá passado o meu pequenino, terá adiantado muito o Shelley? Que grandioso é o poema de Goëthe, que me mandou! Se tivesses paciencia, meu amor, mais tarde aprendiamos juntos o allemão, que gracinha que isso tinha!

Adeus meu noivo muito, muito amado a sua Luch está com sigo, não sabe por onde anda, porque não vê nada senão o seu Sergio... Uma grande saudade

Luisa

[10-7-09]

S abb ado.

Recebi a tua carta, minha Luisa; não te tenho escrito uma linha porque tenho andado em espectativa, sem sabêr se me appareces por ahi. Na quinta-feira perdi por completo a esperança; julguei que teu 
Pae teria partido; e agora, apesar de sabêr que assim não foi, nenhuma esperança me renasceu... Nunca mesmo tive senão bem pouca.

A Mathilde já vae muito melhor, mas o esculápio não lhe permitte que se levante por emquanto. Esta doença tem-nos dado aqui uma vida excepcional e aborrecida. A Pilar entretanto já hontem á noite tocou o seu bocadinho. Lembrei-me de que gostaria de te ouvir tocar, e tive pena de que abandonasses o piano. Bastava-me que tocasses meia duzia de coisas das que me fazem cantar cá por dentro.

Não tenho feito nada, e reduzo-me a vegetar. Poucas vezes abri o Shelley. Até agora não passei da sua obra-prima segundo a universal opinião, o Prometheu Libertado. $\mathbf{O}$ homem é admiravel pela fecundidade de verbo e de imagens, mas pareceu-me muito rhetórico. Os críticos lá terão as suas razões, mas eu acho-o ainda bastante verde no pensamento. E verdade que morreu novo, creio de pouco mais de trinta annos, e eu não li senão uma coisa, e não estou á aluíra de apreciar o estilo inglês. De resto, aborrece-me 1er poesia com diccionário na mão.

O problema da obra futura é mais complicado do que tu imaginas, meu amôrzinho, e espero falar-te para te fazêr comprehendêr o essencial. Se fosse só a obra a escolhêr, era mais simples; o peor é que nem mesmo chego a escolhêr o genero da minha actividade, dada esta maçadora igualdade das minhas aptidões. Esta preoccupação é nova em mim na sua feição actual: se sempre hesitei no meu estudo predilecto, só agora me préoccupa a producção, porque não ambicionava sêr autor. Em especulações filosóficas vi-me mettido por curiosidade natural: fui a ella instinctivamente, inconscientemente, como uma criança bebe o leite. Hoje tomei nesse campo uma posição; posição vaga, em grande parte negativa, como a de todo o homem sincero e livre hoje em dia, mas em todo o caso uma posição. Descanso. Depois, a alta especulação abstracta faz grande mal a um homem que está obrigado a vivêr na vida prática e activa da maneira que eu estou obrigado. Não volto a ella.

Mas, se quizer pensar na producção (da qual, de resto, penso muito bem desistir, o que talvêz ainda seja o melhor) além de todas as difficuldades pessoaes, accrescem as do meio. Aborrece escrevêr coisas que ninguem lê; ora a minha predilecção e o meu genio levam-me exactamente para campos onde poucos sabem podem, querem entrar. Entre nós só são lidos os generos populares (romance, história). Não me sinto nada romancista; e a história hoje já não é um género literário, artístico, como nos bons tempos do romantismo. Aquella narração animada, colorida, dramatizada, cuja fórmula aprendeste em A. Thierry, é sempre individual e arbitrária. Hoje arma-se a historia num grande apparelho de análise sociológica, económica, critica de leis, de textos, análise de documentos, etc., um miúdo trabalho de paciencia de condição que as condições da minha vida não permittem, e com que se não compadecem as tendencias do meu espírito, que eu te não posso definir agora porque sem explicações preliminares me não lograrias comprehendêr bem. Ficará para quando nos falarmos.

Alegra-me que a minha Luch vá achando razão á frase da Catharina de Sienna, mas quero fazêr-lhe a esse respeito uma observação. Tens um único defeitosinho, meu amor, que já sabes bem qual é, e sobre que já te escrevi em tempo. Repara pois que quem mais sabe mais obrigação tem de sêr modesto, mais conhece a sua immensa ignorância, menos ostentação deve fazêr dos seus conhecimentos e dos seus dons. Vê ainda que o accumular no nosso cérebro o que os outros por si mesmos pensaram é um grande prazêr, mas 
não uma verdadeira superioridade da nossa naturêza. Só é especialmente dotado aquelle que cria, o que inventa, e que tem ideas suas, pensamentos seus em assumptos diffíceis, opiniões suas em profundos campos. Sei perfeitamente que te não has de tornar vaidosa á medida que te instruires, mas quero ainda que o não parêças. Melhor seria a ignorância. Se te digo isto, é por sêr pecha em geral no teu sexo. Bem o diz o Guyau:

La science devient pédante,

L'art se déssècha et se flétrit.

Os homens passam annos e annos nas Escolas, veem quanta sciencia ha, que infinidade de problemas; conhecem os professores, muitas vêzes sabedores a valêr na sua especialidade e em outras; viram condiscípulos ás centenas a estudar ao seu lado, quantos d'elles applicadíssimos. As mulheres, a quem em geral não succede isto, e que lidam com amigas ignorantes, em lendo dois livros logo lhes parece que agarraram tôdo o saber profundo e essencial. Peço-te que leias a Bibliografia num livro que a tenha (o Appolo de Reinach, por ex.) e logo verás o que é preciso trabalhar para conhecêr um assumpto. (Acrescentado e entrelinado) (Lembra-te também da carta da Michaëlis).

Se te parecêr isto tolo, não lhe ligues importancia. Se nos falarmos, meu amor, comprehenderás porque te digo isto. Impressionaram-me mais do que te quiz dizêr aquellas frases orgulhosas que me escreveste.

Adeus, minha Luisa, beija-te religiosamente as mãos o teu muito e muito saudoso

A. S.

\section{CARTA DE LUISA STEPHANIA A ANTÓNIO SÉRGIO}

10 de Julho (1909)

Sergiosinho, as 3 horas anciosamente esperadas, passaram e não me trouxeram nada! - Toda a manhã, tenho me occupado a enganar o tempo para o fazer passar mais depressa. A cada passo que ouvia no corredor ficava attenta, talvez fosse alguém com uma carta... Afinal as 3 horas chegaram - chegaram e passaram, não veio nada! Provavelmente não escreveu pensando que já não chegaria a tempo. Justamente p. a evitar a falta de noticias suas, pedi na minha carta para a Pilar, que não deixassem de escrever, porque no caso de não estar em Lisboa me mandariam as cartas para aonde eu estivesse. Também póde acontecer o França por qualquer motivo não haver ido ao quartel, e estar lá a carta presa, ou ainda ter-se perdido. Que pena isso seria! Não tenho juizo nenhum, estou desconsoladissima por não ter tido a alegria que esperava. Que pouca cousa somos na verdade, um nada transforma-nos!...

Agora vou sahir, tenho de ir assistir a uma reunião da «Liga da....* Social»; tenho de fazer um grande esforço; por m.a vontade não me mexia agora, estou tão desanimada que todo o movimento

* [Ilegível] 
me é penoso. É bem verdade que a vida é uma lucta continuada, precisamos sempre luctar com as nossas fraquezas, as nossas miserias...

\section{à tarde}

Voltei agora da reunião. Quer saber uma cousa curiosa? Sinto-me agora mal á vontade no meio de todas aquellas senhoras, serias, conselheiraes, imponentes pelas suas idades, seus trabalhos e suas virtudes. Antigamente era sim, a mais nova de todas ellas, mas sentia-me «at home», naquelle meio. A vida apparecia me com seu quê de solemne de triste... mas agora parece que atabafo alli, sinto me remoçar, cheia de alegria, parece que a minha alma canta com os passaritos nos bosques, que a natureza inteira me sorri e celebra o meu amor! Sergiosinho que grande revolução veio fazer na minha vida! Diga, também sente assim como eu? Quantas graças, quantas, devemos dar a Deus meu Sergio! Como eu queria ver todos felizes! Se até aqui me impressionavam as tristezas e as lamentações dos outros, agora ainda muito mais as sinto, parece que tenho vontade de pedir perdão a todos de ser tão feliz, affigura-se me uma injustiça. Por vezes uma impressão dolorosa junta-se á minha commiseração: sinto-me terrivelmente egoista. Lembro-me que havia pensado dedicar a minha vida a elles que soffrem, e agora abandono-os para pensar na minha propria felicidade...

Domingo 11

Hoje também não tive nada, não tinha que esperar cousa nenhuma, mas apezar d'isso esperava contra toda a esperança. Vamos a ver amanhã ás 9 H- Talvez venha alguma cousa. Todo o meu receio e que se tenha perdido e então n'esse caso, alem do desgosto que isso me daria, ainda a aggravante de ficar n'este anceio uns dias mais. Não se ria, nem me chame piegas, querido, se as suas cartas são a minha maior consolação! Não é porque esteja em cuidado na saude, nem na intensidade do seu affecto, mas é que me allivia ouvi-lo conversar comigo, gosto de saber o que lhe passa pela cabeça, de pensar que aquellas expressões eram o seu sentir da vespera, etc., etc. [Escrito no fím da página:] Não faças caso d'estas lamentações, estava assim piegas pela tristeza de não ir para os Vargos e nervosa com a expectativa.

A respeito de saude, peco-lhe me responda a estas perguntas.

Tem dormido? Quantas horas? Come bem? Quantos leites toma durante o dia? A que horas se deita e se levanta ordinariamente?

Segunda 12 de manhã

Já estou descansada porque não se perdeu nenhuuma carta e era isso que mais cuidado me dava. $O$ meu pequenino estava um tanto tristinho não è assim? A doença da Mathilde, a Luch que não apparece tudo o dispoz mal, não é isso? Olha, meu amor, alegra-te porque podemos continuar a esperar. $O$ meu Pai, ainda hontem me disse, d'esta vez positivamente, que me deixava nos Vargos enquanto fosse a Paris. Tem de ser esta semana, porque segundo telegramma recebido, o João chega no proximo dia 27 (graças a Deus!!) e elle quer estar de volta n'esse dia. Serão poucos dias, mas parece-me que podemos contar com elles. Sergiosinho, que bom, que bom! Já ficou mais alegre, não? Agora vamos fallar em cousas serias.

Então o meu amor pensou que quando disse que lhe era «egual em tudo", me queria comparar intellectualmente consigo? Ora pelo amor de Deus! Até dava vontade de rir! Coitada de mim! O que eu queria dizer é que ambos tinhamos os mesmos direitos. Tudo o que c Sergio tinha direito de exigir de mim eu tinha também de exigir de si; a mesma illimitada dedicação, a mesma confiança absoluta. Não 
era por um sentimento de vaidade que eu dizia que sabia muito bem o que valho. N'essa estima referia-me ao que sou capaz em affecto e dedicação, e sabendo o que isso representa para mim, queria que o Sergio aprecie condignamente o thesouro que lhe entrego, e lhe dê o valor que elle merece. Sou muito ciosa do meu sentimento, e não poderia supportar que elle fosse rebatido ou mal estimado, e por isso fui levada a frisar bem que se o Sergio me dava muito, eu não lhe dava menos; não certamente porque tivesse alguma razão de queixa de si, bem pelo contrario, mas a sua carta havia-me causado uma impressão extranha e desrazoavel (concordo plenamente) de revolta, que eu não sei bem analysar, e como escrevi logo depois de a receber, a minha carta ressentiu-se d'ella. Como vê referia me unicamente aos sentimentos, nunca me passou pela ideia fazer outras comparações. Sei perifetamente que sou muito ignorante e que a minha intelligencia não passa da do «vulgum pecus» (em todo o caso estou forte em latim!!) todavia não me afflijo com isso, sei egualmente que o exforço intellectual não é a nossa principal attribuição, Deus, que repartiu os seus dons, deu-nos uma esphera de acção, mais modesta, sim, mas não menos proveitosa, do que a vossa.

Queres ouvir o que diz Mgr. Landriot na sua «Femme Forte»? «Dans ce magnifique idéal de Turnon de l'homme et de la femme, il fallait deux caractères différents, l'un plus solide, l'autre plus souple....... Le mari, dans cette vie de confiance mutuelle, verse dans

l'âme de la femme, l'intélligence, la lumière, la vigueur et le conseil; la femme de son côté, ombrage la tête de son époux avec une couronne de fleurs gracieuses, elle le dédommage des peines de la vie, elle essuie ses larmes, elle glisse dans ses veines une huile de joie et de bonheur». Fica descansado, meu noivosinho já estou muito emendada do meu feitio antigo, e não ha perigo nenhum que eu me m'envaideça com os exforços que estou fazendo por me instruir. Seja dito de passagem os resultados não têem sido muito brilhantes...

Todavia se achas que ainda não sou suficientemente simples na minha apparencia hei de diligenciar modificá-la.

Não me falia senão d'uma carta recebida no sabbado, não recebeu uma que lhe escrevi no dia 5? [Entrelinhado:] Devia tê-la recebido terça feira passada. Vou mandar esta já hoje para o alegrar um bocadinho. Se estiver disposto (olhe que é só n'esse caso, eu não espero nada) escreva logo que receber esta, sim? A minha próxima mando na quinta, chegará na sexta caso ainda ahi não esteja a Luch. Adeus queridinho, meu Sergio, meu amado, muito breve terá a sua noivasinha ao pé de si. Saudades á Pilar. Deus queira que a Tuca já se tivesse levantado!

Luisa

Disse o tio Raymundo, minha Luisa, que lhe contára teu Pae que só te traria em Agosto. Perde a esperança, como eu perdi. Quando te tornarei eu a vêr, cordeirinha, quando se repetirá uma tarde que me não saia da imaginação? E podia sêr um tempo tão bom, meu amor, tem estado tudo tão bonito! Fui hontem à estação de tardinha esperar o tio Raymundo. Não era nada provável, mas enfim, não era 
de todo impossível que viesses com elle. Apesar de me faltar qualquer esperança séria, - quando o vi só fiquei triste.

E hoje domingo, são quatro e tanto da tarde, venho escrevêr-te um pouco até me ir preparar para o jantar. Não mando esta senão amanhã porque por sêr hoje feriado accumularia duas cartas no mesmo dia com a que hontem te escrevi. Temos tido muito fresco, e de noite mesmo frio. A propósito de noite, ahi tens um soneteto que no passado te compuz:

Mimosa cordeirinha, que encantados

Lhe trazes sonhos taes ao pensamento, Emquanto me amontoas, cento a cento, $O$ afanoso tropel dos meus cuidados,

Repara os astros d'oiro, quão mudados Os vês agora já no firmamento:

Levou a cada um seu movimento

Até serem nas ondas sepultados..

Andaram; mas no ceu, no ceu sublime,

A mesma face divinal exprime

A mesma santa e esplêndida harmonia:

Contemplando a infinita, excelsa Ophir,

Ante as visões eternas avalia

Como a vaidade humana faz sorrir...

No comboio do tio Raymundo tive a surprêza de vêr o Chagas, seguia agora para Entre-os-Rios pelo rápido. Gostei muito do encontro, e distraiu-me da estranha e pouco explicável decepção que tive.

Pensa bem em mim, minha Luisa, e serás humildemente amorosa para commigo. Podes procedêr assim com o teu Sergio, porque o teu Sergio é completamente alheio a vaidades e preoccupações de si mesmo. Nunca me digas cousas menos modestas, em primeiro lugar porque é uma injustiça, uma grandíssima injustiça, em segundo logar porque me feres muito. Segue-me a lembrança do dia $25 \mathrm{Ju}-$ nho como uma garça segue um barco. Não foi a 25 de Junho a ultima vêz que estiveste no Bairro Andrade? Creio que sim. Vejo a tua face, o teu cabello. Lembro-me d'elles, dos teus cabellos, quando olho para os fiosinhos orvalhados de aranha que brilham de manham entre duas folhas. Escreve tudo aquillo que sentires ao teu Sergio, recolhe em mim o teu pensamento como num pombal. Porque me escreves que não podes dizêr tudo que tens a ardêr no coração? Dize tudo, minha Luchezinha, como se monologasses lá comtigo, sem te julgares também obrigada a escrevêr-me com meiguices. Sinta eu a tua alma completamente entregue, e seja o resto de qualquer forma.

Teu, muito teu

A. $\mathbf{S}$.

Venho escrevêr-te duas linhas, minha irmanzinha muito querida, simplesmente pelo deleite de escrevêr para ti, sem que tenha 
nada que te diga. A vida é-nos sempre a mesma santa monotonia que bem conheces: não esperas que te conte o que muito sabes, nem que te descreva os Vargos, os costumes, a paisagem, de resto pouco variada e pouco rica apesar de encantadora. O ceu de dia é sempre sem uma ruga; de noite, agora, estrelado e nêgro; o pôr do sol sem uma nuvem, um disco candente a escondêr-se na Serra d'Ayre. Saio de manhan, de dia e á tarde sempre só. A Mathilde já hoje se levantou e saiu do Guarda-mór, passando o dia lá em casa. A Pilar teve hontem uma febrita e já está boa. Hontem depois do jantar fomos de carruagem (tias Pilar e Mathilde, tio Raymundo, prima Ruth) até ao monumento, onde houve pelas 4 horas festa e sermão. Quando chegámos já tinha tudo retirado, excepto uma meia-duzia de criaturas. Calculo que saberás o que é esse monumento. Junto da estrada de Ourem(?) numa elevaçãosinha nua, um pedestal de pedra, cylindrico, atarracado, sustenta uma Nossa Senhora de Lourdes de aluminio. Uma grade quadrada e dois postes de pár a-raios ao pé com um par de lanternas azues cada um. $O$ sitiozinho é dominante, e para o lado de fóra a terra abaixa-se logo até à serra, cinzeirada de roxo, depois de uma massa recortada e folhuda de vinhêdo e oliveira. Fui triste todo o caminho, e comecei logo por me impressionar muito mal e fundamente com a entrada da pobre tia Pilarzinha para o trem. Imagina o portão cheio de gente, e a pobre senhora, que caira de joelhos sobre a portinhola, a chorar, uma mistura de zanga, de lamento e de penitencia, e eu sem coragem de pegar nella como um fardo e colloca-la sobre o banco. Esta miséria fisica da arterio-schlerose e da senilidade impressiona-me mais que qualquer outra e lembro-me sempre do meu Pae. Que horror que é a doença, meu liriosinho; peço-te muito, e muito a sério, que trates bem da tua saude.

Quando te verei eu, minha Luisa, quando te terei eu! Tinha vontade de te dar um abraço que fizesse de nós uma só pessoa. Descansa, noivasinha, que o teu irmão t'o não pede; basta que me dês a certêza de que estás mais agarradinha a elle em espírito do que uma flor à sua haste. Ainda quando as circunstancias nos não deixassem realizar a obra em que tanto sonhas, já é bello que realizes (e muito bello!) um amor muito completo e muito alto, um abandono maravilhoso ao teu Sergio, que t'o recebe, minha assucena, cheio de amor, de santa aspiração e de vontade. Minha Luisa, minha querida, não podias deitar o teu incenso em urna mais pura e mais lavada.

Terça-feira, 13-7-09, meio-dia

Recebi hoje a sua carta. Não tenha mêdo de parecêr piegas quando fôr verdadeira. O piegas é o sentimentalismo com uma pontinha de ostentação, armando um quasi-nada ao effeito, três quartos de verdade e um quarto de convencionalismo. A verdade tem sempre um certo fogo, ou uma certa força, que se distingue á légua da pièguice. Seja verdadeira até ao fundo e não receie exprimir-se mal. Quando a gente se escraviza à realidade não ha perigos a esse respeito.

Ce que l'on conçoit bien s'énonce clairement,

Et les mots pour le dire se trouvent aisément:*

* 0 2. ${ }^{\circ}$ verso não pode sêr assim, mas não me lembro 
Disse isto o emperrucado Boileau, menos poeta que urna tartaruga, mas o bon [sic] -senso em pessôoa Concevoir bien não é para todos, mas é muito fácil o sentir bien basta não têr preoccupações d'outra ordem.

A noticia da sua vinda não me fez grande alvoroço pela simples razão de que não creio nella. Não creio, minha Luisa, que lhe heide eu fazêr? De resto felicito-me, por sêr este o melhor estado: posso têr uma grande alegria e não terei decepções. As coisas muito desejadas não succedem, diz o amigo La Bruyère, ou, se succedem, não é na occasião nem nas circunstancias em que fariam um grande prazer.

Gostei da citação do ecclesiàstico. É pena que tanta gente leia, pense, diga aquillo, e tão pouca realmente se lembre de o praticar. Como viu, risquei a palavra "pense», que primeiro escrevêra, porque quem verdadeiramente pensa já começa a praticar. A maioria da gente escorrega pelas coisas e julga que as pensa, como olha, para os objectos e julga que os vê. Pensar, meu amôr, não é isso. E entrar dentro das coisas, fazê-las nossas, vê-las nitidamente, traduzidas em imagens proprias para nosso uso, bem pregadas nas nossas cabeças, digeridas [?] e transformadas em sangue. Uma idea assim tratada gravame na nossa alma, modifica a nossa estructura e produz a sua acção ainda que nós não tenhamos d'isso consciência. $E$ preciso ruminar bem as três ou quatro imagens essenceaes que hão de dirigir a nossa vida, e digo imagens porque é preciso traduzir o ideal em figuras concretas que se projectem na imaginação. Os estoicos liam as vidas, as acções dos seus modêlos, e esses pequeninos quadros tinham mais podêr que os preceitos e a eloquência.

Sinto uma grande doçura em vêr nas suas cartas o tu; mas é preciso que nos não acostumemos a elle, para não custar a maior cerimonia quando estivermos diante de gente. Vou respondêr ás perguntasinhas. Durmo bem, umas 6 horas, o meu máximo. Um copinho de leite pela manhan. Deito-me das 11 para as 12, já levantadinho e na rua às 6 . Não como durante o dia senão às duas refeições.

Bem sei que lhe mandariam a correspondencia. Mas que cara faria a minha Luch quando a tia Mathilde ou a prima Ruth lhe fossem entregar cá nos Vargos uma carta minha recambiada de Lisboa?

A. S.

Prosegue, meu bem, que emquanto

Gorgeias ventura e maguas,

Eu vogo sobre o teu canto

Como um cisne sobre as aguas...

Envolvem-me, como um manto,

As tuas canções: e eu trago-as

Por um palacio d'encanto,

Longe da terra e das frágoas...

Prosegue, meu bem: cantando

Vaes o meu sonho embalando,

Onde o enlêvo não dorme... 
Bemdita a que Deus envia

Para que as almas transforme

Em fluctuações de harmonia!

Senhora D. Luisa que eu odeio:

21 Julho 1909 (À noite)

Havendo-me lembrado de si por acaso neste momento, tenho a dizêr-lhe que a acho uma criatura muito antipathica, e que preferiria o inferno a têr de supportar um anno comsigo na mesma casa. Saiba que ha um cavalheiro que saltaria agora de contente se lhe saisse a sorte grande e não fosse marinheiro. Diz elle que se tal acontecesse, em menos de 3 dias seria pedida ao seu papá certa Senhora muito prendada, como são todas as Senhoras cujo nome vem no jornal. E a dita senhora seria levada de casa de seu Pae para longes predios; e depois não haveria remedio senão sêr muito meiga com o dito senhor; e conservaria as mesmas iniciaes do seu nome, mas havia de mudar os seus dois apellidos em $S$ por outros dois appelidos também em $S$; e depois o mesmo senhor todos os dias a havia de obrigar a ouvir-lhe coisas dôces; e depois acabar-se-ia esta historia para começar outra. E na outra historia haviam de apparecêr as mesmas duas pessoas muito juntinhas, como duas amêndoas na mesma casca (de que se fazem «filipinas»); e depois eram tão iguaes que já ninguem as distinguia; e a senhora constantemente se aperfeiçoava, se aperfeiçoava, cada dia mais bonita lá por dentro; e por fim era mesmo mesmo uma santa das que a gente põo no altar; e tanto gostava do seu senhor que fazia maravilha; e nunca se viu no mundo outra senhora que gostasse tanto de um senhor...

V. Ex.a naturalmente não se commove com esta historia, porque tem o coração mais empedernido do que um pão de três dias; mas fique sabendo que ainda ha pessoas menos feras que sonham ás vezes com coisas d'estas. Aconselho-a a que vá perdendo esse genio, e se torne mais sensivel, para se educar neste sentido habitue-se por exemplo a mostrar ternura ao seu amado: talvêz com tal processo consiga abrandar alguma coisa a sua má indole e ruins fígados.

Quando Orfeu tocava a lira, as proprias árvores o escutavam: até as coisas inanimadas são sensiveis às falas dôces. Medite V. Ex. ${ }^{a}$ este exemplo, e envergonhe-se da sua esquivança. Nem é preciso ir buscar os exemplos tão longe, á antiguidade e á fábula. Ha aqui no Quartel um moderno, um eléctrico, um industrial, um prosaico telefone que já parece uma alma christan, à força de vêr na cara de certo sujeito as expressões de carícias que não podem ir no fio. $O$ patife do telefone guarda tudo - porque o outro nem tuge, com mêdo das meninas da estação. Porque elle sempre ha homens que teem mais mêdo das taes meninas que d'um esquadrão da Municipal...

Adeus, minha Luisa, não posso continuar. Receba um longo, um fundo aperto de mão. Seja dia a dia mais alta, mais ideal, mais nobre, tome muito cuidado em si para sêr em tudo o mais bonita possível. Repare que com a sua pessoa hade dar ao seu Sergio um thesouro acabado e inestimável. Dou-lhe em fantasia um abraço apertado, apertado, de maneira que no meu coração se viesse refleccir cada pancada do seu. Ah, minha Luisa, que bom seria encostar a minha cabeça 
ao seu peito e ficar para ali a segredar-lhe muito baixinho... Luisa, Luisa, Luisa, minha Luisa, minha graça, minha pomba, hade-me convencêr um dia, com os seus labios, hade-me dizêr que me ama muito, como eu a amo...

A. S.

\section{CARTA DE LUISA STEPHANIA A ANTÓNIO SÉRGIO}

\section{Meu Sergiosinho, meu pequenino}

28-7-09

Tenho estado n'uma grande anciedade porque já me tardava o meu irmão. Haviam dito que o vapor chegava de madrugada e os passageiros desembarcavam logo de manhã de maneira que desde as 7 H que estou á espera d'elle e já começava a perder a esperança até que me animei a perguntar para o escriptorio e tive a alegria de saber pelo Snr. Teixeira, o guarda livros que elle chegou e está de saúde e que já o tinha abraçado. Que grande allívio, meu Deus! Não desembarcara ainda por uma razão qualquer que eu nem ouvi no meu alvoroço de o saber chegado! Meu querido Joãosinho! que N. Senhor lhe ponha a virtude! Estou com immenso medo de o ver, deve chegar a casa ao meio dia.

Meu Sergiosinho esta manhã ao acordar senti um grande pezo, que differença do acordar dos Vargos! Como eu me vestia tão alegre tão contente com a ideia de te ver d'ahi a bocado! Apezar de ter muitas saudades tuas, estou ao mesmo tempo muito calma. Estou segura de ti, meu amor e sei que estamos m.to agarradinhos um ao outro. Nós já fazemos uma só pessoa, não é verdade? A união das almas é a que mais importa e essa vai progredindo muito, graças a Deus. Sinto me cada vez mais tua, meu Sergiosinho e tu cada vez mais

meu Olha fui lá acima, examinei tudo com olhos de ver e muito

attentamente. Compenetrei-me bem da m. ${ }^{a}$ responsabilidade e com franqueza fiquei desanimada. Parece-me que nada se poderá fazer por esse lado. Mas veio-me outra ideia e parece-me esta racional. Junto mando-te o plano da nossa casa. Lembrei-me que poderiamos occupar uma parte d'ella e estarmos completamente independentes. Para isso bastaria levantar uma parede que dividisse o corredor onde marquei com tinta encarnada. As outras 3 portas trancavam-se e estañamos na nossa casa. Em cima tinhamos uma boa cosinha e casa de jantar e era um ideal. Que pensas d'isto, não achas boa ideia? Não transtornava nada o Papá porque é justamente a parte que eu actualmente occupo. Manda me dizer o que te parece d'isto.

$5 \mathrm{H}$ da tarde

Meu Sergio já veio João eram quazi 5 horas da tarde quando chegou a casa!! Não teve muita pressa de abraçar a familia! Desde as 6 horas que chegou o vapor!

Vem com bom parecer mas dá-me a impressão que se julga uma victima de ter tido de voltar para casa. Impressionou-me a chegada d'elle. O Papá ainda o não viu. Esta manhã recebeu outra carta de Buenos Ayres fallando a respeito do João e pedindo 25 libras que elle estava a dever! Estava muito irritado contra o João e disse 
mesmo que não queria jantar á mesa com elle eu lá deitei agua na fervura conforme pude mas estou anciosa pela entrevista dos dois.

O João diz que vem disposto a entrar numa vida pacata e «dedicar-se á sua irmã» (palavras d'elle) mas coitado não sei o que será. A respeito da tal menina, escreveu lhe na vespera da partida p. ${ }^{a}$ aqui está á espera de resposta, vamos a ver não ha portanto nada decidido. Será o que Deus quizer.

Adeus meu filho meu Sergiosinho querido não me posso demorar mais. Recebe toda a m. ${ }^{a}$ alma e todo o amor da tua

Luch

Vargos, 29 de Julho (-09)

Minha Luisa

Mergulhou a carruagem do alto da estrada, voltámos para a Cerrada do Pôço, caiu a noite: aqui tens, em quatro palavras, o resumo de uma coisa triste. A tia Pilar, ao serão, dizia chorando que lhe fazia muita pena toda a pessoa que se ia dos Vargos: faltava a cantora, a leitora... Depois a conversa rolou toda sobre ti, o teu Pae, o mano João: se viria, se não viria, como seria recebido, o que teria feito, que censuras merecia o seu procedimento no Brazil, a quem mais caberiam culpas do seu estouvamento. Eu ia ouvindo. Ás 10 e tanto retirou tudo, sem esperar pelas damas que voltariam do Entroncamento. Fiquei só na casa de estar, puxei a poltrona para o candieiro, abri um livro, esperei e não li Estavam de volta às 11.

Só hontem estive na varanda à noite. Havia lua já clara e muito rumor [?] nos plátanos. Não tive a visita branca de passinho leve. Porque nunca consegui eu estar de alma larga, sem a preoccupaç̃o das mesquinhas considerações que estariam fazendo os outros? Mas assim é. Uma coisa electrizada, em tocando a terra fica Ioga desilectrizada absolutamente: tal me succede a mim. Paciência.

Passei hontem o dia lendo Os Cenci de Shelley. Apesar dos elogios do crítico, não me enthusiasmaram. Achei francamente construido, e os caracteres muito elementares e de um vago esboço. As personagens não foram verdadeiramente vistas e sentidas por dentro. D'ahi a impressão de rhetórica superficial. Em compensação as pequeninas poesias teem bellas e poeticas imagens.

Para que te heide eu dizêr, meu amôr, que tenho saudades tuas, que procuro realizar em imaginação a tua figura girando de sala em sala, com o vestido do primeiro dia, e me vou embalando nessa imagem como uma criança no seu bêrço? As sombras do plátano lá continuavam hontem a oscillar com doçura no muro aluarado, e a fazer lembrar carícias brandas. $E$ tu, que farias? Conta-me que se passou. São agora nove da manhan, estou no Guarda-mór e a Pilar e minha Mãe foram à missa. É possivel que tenha d'aqui a pouco carta tua, mas só realmente espero amanhan. Hontem foi o dia consagrado á recepção do mano, e a tudo mais que a isso se liga. Tenho grande curiosidade de sabér como se teriam passado as coisas, e se terias tido muito que te apoquentasse. Adeus. Se receber 
carta tua acrescentarei um Post-scriptum no espaço que para isso aqui fica.

Teu

A. S.

P. S. Recebida a tua carta. Oxalá o mano João cumpra. Vê se lhe aproveitas agora as boas disposições.

A. S.

Não me admiro de que te fizessem profunda tristêza as palavras do livreco, porque também a mim me succederam coisas similhantes várias vêzes, até comprehendêr bem que as palavras e os sentimentos representam coisas completamente differentes comforme as almas que as concebem. Em almas lamacentas é tudo lama, e as almas lamacentas são neste mundo a esmagadora maịoria, - gracinha de que deverias louvar o Deus em que acreditas. E essa mesmo a primeira razão por que eu não acredito n'Elle - com $E$ grande em consideração por ti.

Foi em nome da justiça que crucificaram Jesus-Christo; é sob a palavra «amor» que a maioria da gente esconde as paixões mais vis, e os mais repugnantes dos cinismos. Como se não póde inventar uma palavra para cada objecto particular, fica sabendo que ha tantos «amores» neste mundo quantas as almas, - e se quizeres conhecêr o teu, ou o meu, procura exemplares nas almas que nos assemelhem. Querer que o amor de um Sully-Prudhomme, por exemplo, seja o mesmo do que elle é para um bebedor do Moulin-Rouge, seria o mesmo que pretendêr que o mel que segrega a abêlha fosse a mesma coisa do que a baba venenosa que segrega a vibora. Os animais são differentes - voilà tout:

Cada um dá o que tem,

Comforme a sua pessôa...

Deves abstêr-te de lêr esses livrecos que a canalha de Paris produz para a canalha de todo o mundo. Mesmo em livros de bons e nobres autôres podes encontrar coisas similhantes, porque o autor expõe as opiniões e os costumes das suas personagens, e não as opiniôes próprias. Shakespeare não tem responsabilidade no que diz lago; e Camillo defendeu-se de uma accusação similhante dizendo que se a sociedade queria que elle lhe apresentasse retratos menos repugnantes, tratasse ella, sociedade, de se apresentar menos vil. E muito podre, a humanidade, mesmo em grande numero d'aquellas pessoas que te convencem da dignidade do seu feitio, e da sua purêza de intenções. Escrevia o Flaubert a um amigo que não era preciso entrar na sociedade para se avaliar do que ella fosse, - como bastava passar por certas cosinhas nausebundas para sem provar a comida percebêr que ella seria «à faire vomir». E melhor abstêr-te de entrar nessas coisas, mas não sejas ingénua em relação ao bicho homem. 


\section{António Sérgio}

O teu exerciciozinho de resumo para principiante é de primeira ordem. E preciso entretanto que repenses mais, apegando-te menos ao texto. De resto, sem exagêro algum te digo que o resultado foi muito lisonjeiro. Se te vou fazêr reparos é porque não tendo tu attingido ainda a perfeição, acho conveniente indicar-te o caminho em que está a meta a attingir. Colloca-te de longe, de maneira a vêres a carcassa $\mathrm{e}$ as linhas essenciaes, para podêres escrevêr o verdadeiro esquelêto da doutrina. Sente-se até que te agarras ainda de mais ao texco porque escreves em francês com palavras portuguêsas. Exemplo: «Na literatura do tempo principalmente isto se torna notório», etc. A construcção portuguêsa seria: «Torna-se isto principalmente notório, etc». Nota em linguagem tua as ideas essenciaes, como fizémos nos Vargos; lê e relê attentamente essas notas, procurando vêr bem a ligaçãoo entre ellas; deita depois os apontamentos para o lado, e escreve a exposição como se se tratasse de ideas tuas, manejadas bem por ti, mas sem deturpar o pensamento do autor. Consegui-lo-ás facilmente, porque a primeira prova foi já muito boa. Tenho muitas saudades tuas, minha querida Luisinha. Vê se harmonizas teu Pae e o João, mas como quem não quer a coisa, diplomaciando por detrás da cortina, sem falares directamente a teu Pae no assumpto, sem que elle te supponha intenções de intervir. Acompanha teu irmão o mais possivel, seduze-o, conquista-o, enlaça-o, fazendo-lhe apparecêr o mais florida possivel a nova estrada em que pretende mettêr-se, mesmo que não tenhas esperança de successo. Seja elle, agora, a tua primeira e importantissima occupação. Varia os meios de o entretêr, vae recebê-lo mal elle vier de fóra, arranja-lhe pequeninas surprêzas todos os dias, um bonito ramo de flores a enfeitar-lhe o quarto hoje, amanhan um retrato, etc., de maneira que elle sinta constantemente a tua presença a velar por elle. Não lhe faças pregações nenhumas por emquanto: é preciso primeiro encantar as pessoas para depois as podêr levar. Diz-se que o jacaré se deixa comêr pela hiena porque esta o encanta. Aprende o segrêdo da hiena, e repara que tudo isto é para um grande e bello fim: o conseguir que elle seja ainda o perfeito rapaz que póde sêr.

Adeus, minha Luisa. Estou amanhan de serviço (3). Tenho cá dentro um montão de saudades. Manda-me um resumo do Idéal dans VArt (2. ${ }^{\circ}$ volume do Taine) Lê depois o Guyau (L'Art au point de vue sociologique),

Teu e muito teu

A. S.

4 de Agosto, (1909) 2 h. da manhan.

Minha Luisinha:

Assim é, meu amôr, são esses os principios da "sociedade», do «mundo», de «toda a gente»: convence-te de uma vêz que assim é, mas não percas nunca a santa indignação, as....**

«haines vigoureuses

* [Ilegível] 
Que doit donner le vice aux âmes vertueuses", como diz o Misanthropo. Por essas e por outras é que elle era era misanthropo. A acção é sempre moral quando nos não leva á cadeia, nos não traz pancada, ou nos não custa dinheiro. Roubar uma mulher póde sêr uma má ou boa acção, conforme o marido nos desanca ou nos não desanca. Não estou contundido nem arruinado, não necessito arnica nem um empréstimo? Procedi honradamente e sou um Santo.

Sentes o rapaz escapar-te. Hontem á noite, ou antes, ante-hontem, visto que já te escrevo a 4 , falando commigo e com o Raymundo, lamentou-se da falta de divertimentos: que Lisboa estava uma sensaboria, etc. O Raymundo confessou-lhe que aborrecera já tudo isso e estava pacatissimo. Teu irmão retrucou que era porque o meio não prestava: se elle fosse lá para fóra veria como retomava o gosto, etc. $\mathbf{E}$ ahi tens.

Queres que te fale de mim, meu amor? No dia 1 apresentei-me, fui á Ruth, e depois jantámos no Quartel do Carmo; em dois (2) emendei todo aquelle Refugio dos Vargos, porque o caso historico se não passou com uma esquadra, mas com um navio, e escrevi um sonêto ao Infante Santo. Eu te digo porquê: o França quiz por força que eu mandasse essas duas coisas a uns jogos floraes que vae havêr em Salamanca (uma das coisas a concurso é um sonêto a uma figura histórica portuguêsa). Eu não tinha vontade nenhuma, entre outras razões porque o juri são uns sujeitos portuguêses que hão de premiar os seus amigos. As peças são simplesmente assignadas com um lemma, o qual se põe sobre um sobrescrito fechado que contem o nome do concorrente: só é aberto o sobrescrito cujo lemma for o da peça premiada: mas isso não impede que elles saibam particularmente das peças dos amigos. Depois, o Refugio não é grande coisa, e as subtilézas descriptivas, puramente maritimas, não as comprehendem elles; o sonêto é abstruso, e terá a mesma sorte, como obscuro, incomprehensivel, etc. Pois se os senhores literatos até acharam incomprehensiveis certas poesias das Rimas claras e simples como água! É com muita repugnância que concorro, mas o diacho do rapaz não me largou, e não o quiz contrariar mais. (Não diga nada a ninguem, porque nestas coisas o segrêdo absoluto é da praxe, como bem comprehendes que deve sêr). Ha mais duas peças a concurso, uma bucólica e uma satírica, mas lá isso decididamente é que não mando nem mesmo me sinto bucólico, nem vou satirizar ninguem, porque não estou indignado com pessoa alguma. Hontem estive de serviço, e levantei um auto. Agora estarei de quarto até às 5 (alvorada), deitar-me-ei a essa hora, tentarei dormir um ratito, falar-te-ei ás dez, sairei ás onze. Depois, não sei ainda que farei, e se me ficará descaramento sufficiente para ir vêr a minha pequenina com o pretexto um tanto hipócrita da solicitude por uma doente que já está boa. Que cuidado tem este maldito com a saude da sua prima, que nem póde esperar pela noite como é sempre seu costume!...

Adeus, minha Luisa, tenho de me interrompêr aqui porque o serviço de Sua Majestade me reclama. Passei o dia um pouco tristonho, por mil coisas várias, geraes e particularíssimas, mas nada de novo e que menção merêça. Como vês não me aproveitei da tua dispensa de te escrevêr, mas apreciei o bom-senso e intelligencia com que me dispensáste. Adeus, meus amor: mando-te um grande, grande, grande abraço.

Teu marido muito grato

A. S. 
Minha Luisa:

[4-8-09]

Escrevo-te de casa do França. Saí de casa às 7 da manhan, para que me não viesse algum accesso de máu génio com um certo cháos e um certo barulho, que hoje começou cedo. Fui lêr para o jardim de Santos, e agora vim almoçar com o rapaz. Aqui tens a vantagem de se têr amigos. Dão-me de quando em vêz refúgio contra o meu próprio lar. Emfim, tenhamos paciência.

Ficou-me remorso d'aquella historia do $\mathbf{E}$ grande. Minha Luisa, nada ha que eu mais vénéré e admire que a religião christan. Adóro o teu Deus sempre que me apparece na sua bondade e na sua justiça. Como Criador é que hesito... Por isso arranjei para mim esta concepção original, que acharás extravagante: um Deus que não foi o criador d'este pessimo mundo material que nós vemos, mas que es cá actualmente na faina de criar sobre elle um outro mundo, o mundo das Ideas, o mundo moral que se vae formando. $O$ meu Deus é pois um Transformador, um Redemptor, que sobre a matéria da primitiva e obscura criação, vae fazendo surgir a sua criação moral. Estamos no seu início: é essa idéa que expendi no ultimo sonêto da Palestra fantástica, cujo alcance ninguem me mostrou ainda que tivesse comprehendido:

É que Deus mal desponta. É como infante

Que balbucia apenas, treme e chora

Nos corações que anceiam pela aurora

D'um ignorado Sol que vem distante...

... Tu reinarás talvêz no todo immenso,

ó Supremo Ideal das almas puras!

E essa seria a Criação.

Sê cada vêz mais religiosa, minha Luisa, mas cada vêz mais interiormente religiosa. "Louvores infinitos ao Deus santo que outorgou o dom da fé a um punhado de terra» diz o Saadi.

Até logo á noite, lembra-te muito e ama muito o teu

A. S.

Sabe a minha pequenina que é sempre uma coisa melancólica o jantar-se só num navio ou num quartel? Sabe que achei certa delícia em têr na sobremêsa um pedaço do bolo inglês que nos offertou? E sabe ainda que nunca, ou bem poucas vêzes, senti mais a definição do $\mathrm{V}$. Hugo, que a melancolia — c'est le bonheur d'être triste?...

Ora, se queres conhecêr teu maridito no seu quartel depois de jantar, direi que às $5 \mathrm{H}$ fui commandar um exercício de infantaria, - que é assim uma coisa de um homem a berrar e 50 mari- 
nheiros a mexêr, mail' uma fanfarra a fazêr barulho. E ás 7 horas acabou a dansa; e depois passei revista aos reforços, que são uns marinheiros formados e a gente a vêr se elles estão bem postos; e depois foi a revista aos presos, a verificar como estão sob os ferros d'el-rei todos aquelles que devem estar. E depois passo a escrevêr á minha Luch, até que ella me fale ao telefone. $E$ aqui está o que se chama escrevêr em estilo biblico.

Tirando o professor, o verdadeiro professor, que educa as gerações novas; tirando o homem de laboratório e de gabinête, a quem se lhe permitte que consagre a vida, profissionalmenxe, ao saber; tirando o verdadeiro artista que realiza a bellêsa alta, e vive com ella; - as outras profissões da cidade não são, realmente, mais bellas, mais poeticas do que esta minha de marinheiro e militar. $E$ d'ahi... O commercio não é mais bello, o escritorio, o Deve e Haver; mas algumas indústrias talvez o sejam... «Mas por outro lado, etc.» — diz urna canção do El-rei que rabió...

Alegra-me o sabér que estás fazendo um «catecismo», como lhe chamas, porque isso me mostra o teu sério desejo de termos precisamente os mesmos gostos, o mesmo génio, as mesmas aspirações, - o que seria, meu amor, o próprio ideal, a suprema e verdadeira união! Oxalá te não aborrêças nunca da monotonia do vivêr caseiro e retirado, que eu tanto ambiciono, da existência exclusivamente íntima, retirada, emsimismada (imitando um termo hespanhol) simplicíssima. Si je croyais encore au bonheur, je le chercherais dans l'habitude, disse o homem do Genio do Christianismo; eu creio nelle ainda, e quero procura-lo onde indica o mesmo senhôr de Chateaubriand: dans l'habitude, na vida retirada, (nesta altura fui falar-te ao telefone) na vida retirada, simples, com a minha Luch...

Lembraste-te muito dos dois annos, meu amôr. Alegrar-me-ia a idea d'essa ausência se me dessem agora a certeza de que acabada ella poderiamos sem difficuldades e sem sacrifícios grandes para ti, realizar o nosso sonho. Ai hontem, hontem, Luisa, minha Luisa, que fugitivos e bellos segundos tu me déste, dizendo-me que estavas plenamente descansada em mim, fazendo-me entrevêr que eu preenchia a tua alma e o teu ideal, que profundamente agradecias a sorte que me deparára ao teu caminho. Adeus, minha Luisa, ama-me, educa-te á minha imagem, faze qualquer coisa por mim, que tenha relação commigo, de maneira que sejas uma só vontade e uma só pessoa com o teu muito amante

A.S.

Minha Luisa bem-amada:

Gostei muito, muito, muito da tua carta. Se sinto vontade de dizêr muitas coisas, meu amôr, se sinto! - mas é que, sabes tu, faz-me mal pensar nos instantes d'ouro que tenho tido ao pé de ti, porque me irrito de impaciência, porque me exaspéro de estar ausente, porque me quebram, porque perco toda a serenidade, todo o equilíbrio, toda a resignação. Se soubesses como desanimo, como toda esta màchina se estilhaça e se extenúa pela vivacidade das minhas imagens! Um minuto de emoção fervente desequilibra-me. Perdôa- 
-me este contra, que é a consequência, o acompanhamento inevitável e natural de certas qualidades. Se aprecias estas, acceita resignadamente o reverso da medalha. Quando era aspirante levava uma ginga, ida e volta, a remos, d'aqui à Trafaria, - e desembarcava frêsco. Com meia-hora de emoção imaginativa era desandar certo.

Quanta vêz me tenho agarrado a um livro para deixar de pensar em ti! $E$ depois, meu amor, teria receio de te dar aquella mesma impressão que tu, sem motivo algum, te arreceias de me dar a mim: porque eu não poderia em caso algum julgar mal do teu amor, e tu poderias interpretar mal o meu, se as minhas expressões não fossem, como tu dizes, «ajuizadas»: - poderias julga-lo, como são tantos (tantos!...) um capricho sensitivo, uma explosão de adolescente, com muito mais imaginação fantasista do que seriedade e profundêz, verdadeira affeição, verdadeira alma. Não sei se disse claro, não sei se me comprehendes, minha pequenina bem-amada...

E mais ainda: tenho sempre um mêdo pueril que uma carta se perca, outra pessoa a leia, que logo torcêsse as coisas pelo viés da sua malicia. Saberiam ou não quem a escrevêra, o que me era indifférente; mas sabiam certamente, pelo sobrescrito, quem era a destinatária- e era isso que me ralaria.

Ouve, minha querida, minha doce, meu refúgio lenitivo, domus aurea, como dizes na tua ladainha: não tenhas mêdo de parecêr criança, nem de coisa nenhuma, dize-me tudo que te vier á alma, fala sem preoccupaçốes, porque t'as não merêço, deixa-te ir nessa necessidade de deixar expandir toda a ternura, toda a doçura, toda a vibração e commoção e cicio do teu peito; - porque tudo isso sente, e muitas coisas mais do que isso, (diga-t'o muitas vêzes ou poucas, com insistencia ou fugidio) o teu muito grato, e muito amante, e muito fervoroso

A. $\mathbf{S}$.

Luisa, confessa-te uma grande, uma profunda, uma apaixonada e dilacerante saudade o teu muito amante

A. S.

\section{CARTA DE LUISA STEPHANIA A ANTÓNIO SÉRGIO}

Meu Sergio bem-amado

s. d.

As tuas duas linhas d'hoje tão repassadas de sentimento, causaram-me uma grande, uma funda alegria. Meu Sergiosinho como tudo que me vem de ti entra-me tanto cá dentro! Estou tão feliz 
hoje, parece-me ainda um sonho ter fallado hontem com o Papá e ter sido tão bem succedida. Meu Sergiosinho parece-me que podemos alegrar-nos muito, muito.

Eu contei tudo como se havia passado, sublinhando bem a maneira por que sempre te portaste comigo, nunca deixando transparecer o teu sentir procurando evitar-me durante tanto tempo, até que um dia as cousas chegavam a uma crise e eu deixei-te entrever o que se passava na minha alma. Disse-lhe então as nossas ideas de futuro quanto estava ainda longinqua a realisação, e o desalento que me fazia a perspectiva de uma ausencia de 2 annos para só depois, podermos pensar no nosso casamento. Lembrei-lhe que já não tinha 20 annos e portanto não me podia reconciliar com a ideia de desperdiçar ainda mais dois annos da minha mocidade longe de ti, sem haver para isso uma absoluta necessidade. Disse-lhe que nunca havia gostado de ninguem senão de ti, que só comtigo poderia casar, que preenchias completamente o meu ideal, tinha a certeza de que me havias de fazer feliz; fallei-lhe nos teus sentimentos, na tua vida, no teu talento, enfim disse tudo o que sentia.

Elle, ao principio, expondo as suas razoes, fez difficuldades. Eu respondi que todas essas considerações, já tu as havias feito antes d'elle, e que eram ellas justamente que te haviam impedido de me fallar antes, e agora, de dar o passo definitivo, apresentando-te ao meu Pai. Disse-lhe também que toda aquella minha conversa era de motu-proprio, que tu nem sabias que eu estava fallando sobre o assumpto, e que eu, como sua filha, que sabia que elle tanto estima, lhe vinha pedir para coadjuvar a nossa felicidade já que só por ti, eu podia ser feliz. Houve depois um bocado de silencio.

Depois, meu Pai, agarrou-me a cara, e acarinhando-me disse: - «Tu sabes que consegues tudo de mim. Não te apoquentes que tudo se ha de arranjar. Para que estou eu cá n'este mundo?? Tudo quanto eu tenho é de vocês e para vocês o tenho ganho. Não posso é supportar a ideia de que possas passar alguma privação. Deixa estar, eu hei de fallar com elle, tudo se ha de arranjar». Depois abraçou-me muito, estava commovido e chorou, coitado! Disse-me que sabia que eras um excellente rapaz, que gostava de ti, que estava bem ao facto da tua vida.

Com franqueza, com franqueza, meu Sergiosinho eu não esperava que tudo corresse tão bem. Sabia que elle havia de acabar assim, mas esperava muito maior «introducção» a julgar pelo costumado. Sinto-me feliz, parece-me que temos um grande passo dado. Tenho ideia que será o meu Pai o proprio a apressar as cousas, eu disse lhe tanto, tanto que d'ahi dependia a minha felicidade! Quem sabe, talvez eu podesse ir agora comtigo? Que bom, que bom que isso era! Meu Sergiosinho pensa que talvez d'ahi a 6 mezes podessemos estar casados, quer dizer juntos para sempre, sem receios de ninguem nem de cousa alguma; um do outro á face do ceu e do mundo inteiro!... Meu amor, meu amor, que felicidade tão grande! Chega-me a parecer demaziada para este mundo! Dize-me que não vês difficuldades, que tudo se ha de arranjar, que estás também muito feliz, muito feliz como a tua Luch. Oh meu Sergiosinho, pensa como havemos de ser felizes. Como eu queria ter-te agora ao pé de mim!...

Adeus, a tua Luch é toda tua, e ama-te muito, muito, muito. Meu Sergiosinho!! 
[escrito verticalmente:]

O Papá hontem estava m.to bem disposto comigo, creio que tudo lhe correu bem não me deu pormenores. Saudades á Pilar.

\section{Minha Luisa:}

Segunda-feira, 9 de Agosto (1909)

Comecei muito melancólico o dia d'hoje, e acabei-o muito bem. Hontem á tardinha appareceu-me o França. Saí com elle, que ia jantar com o irmão e um conhecido a um d'aquelles restaurantes da Praça do Duque da Terceira, ao ar livre. A coisa ao princípio interessou-me, porque estavam bem illuminados, pittorêscos, com sextetos, damas de certo tom, e outras elegantes de vestido claro que passavam na luz áurea. Era uma fantasmagoria nova para mim em Lisboa, sentia-me em terra estranha. Mas depois foi preciso afinar pelo meio, entrar na conversa, achar graça ás anécdotas, etc. À volta, como havia música no Terreiro do Paço, tive occasião de observar as turbas, - e veio-me um tédio enorme do bicho homem, este meu antigo horror á falta de limpidêz de tantas almas, á bestialidade ingénita, feróz, sanguinária. A noite ia seguindo muito lenta, $-\mathrm{e}$ diluia-me na saudade de não sei quê de muito vago e de indistincto, e depois dos dias dos Vargos, e do teu canto, e da tua imagem, e das tuas palavras, - a sua doçura suavíssima, os seus arrobos, os seus extâsis, que eu gosava muito no íntimo, sem t'o dizer, sem t'o fazêr suspeitar talvêz. Todas as lembranças me iam caindo dispersas, tremulando, como borbolêtas que desmaiassem. Tenho muitos momentos de pura contemplação interior, são mesmo os meus momentos mais naturaes, todo eu transformado em alma aerea, numa surda palpitação, num respiro, - e vem-me o receio de que te não agrade muito afinal este genio, por abstracto, por sonhador, por maluco: arreceio-me de que não haja de sêr bem o marido de uma mulher, mas um devaneio, chimera ou sombra que a acompanha. Cheguei a casa cansado, com uma grande vontade a uns tempos de exercício, de gimnástica, de esgrima, de natação e de passeio, de qualquer coisa que me fizesse entrar na vida real, activa e física, attentar nas formas nítidas, sentir que tenho peito e tenho braços. Dormi pessimamente e acordei negro. Chego ao Quartel e dás-me a notícia da conversa com teu Pae, - primeiro acontecimento feliz. Como me não tivessem encarregado ainda de nenhum serviço especial, num intervallo abro o Mario Pilo que mandei vir para ti e começo a encontrar objecções ao homem, - e logo reparo que das minhas objecções vae saindo o esquelêto de uma construcção, o vulto de uma teoria esthetica minha; - segundo acontecimento feliz. Que dizes ao caso? Fiquei perplexo. Não estava isto nos meus planos: irei dedicar-me a desenvolvê-la, abandonando o que tencionava fazêr? Deixarei a arte, para passar a criticá-la?

Aqui ia, minha pequenina, uma d'aquellas cartas que tu chamas muito ajuizadas e muito sérias. Mas quê? - Já te expliquei tudo na minha penúltima. Além do que, se souberes sentir bem a vida das palavras, percebêr as meias-tintas, adivinharás sentimentos que se entremostram sem se confessar precisamente. $E$ é às vêzes bem 
melhor o que se adivinha do que o que se ouve claramente. Não m'o disseste tu das quatro linhas que te escrevi hontem à noite?

Não tornes a falar ao teu Pae em mim, mostra-te plenamente confiada nelle, paciente, supportadôra das delongas. Sê com elle o mais carinhosa possível, grata, cheia de vontade para lhe satisfazêr os desejos, os passeios, etc.

Adeus, minha Luisa, são quasi duas horas. Acabo de dar uma volta pelas paradas. Vi o crescente na direcção em que devia estar a tua casa. Oxalá elle pudesse suscitar sonhos em que sonhasses commigo. Manda-te um beijo de cristal o teu

\section{A. S.}

Sempre me acharás «ajuizado» de mais. Meu amor, meu amor, se soubesses quanta vontade tenho de te abraçar já talvez não dissesses isso.

[10-8-09]

Terça-feira, no Correio geral, 3 da tarde.

Minha Luisa: o Mene dá amanhan um jantar ao Pereira de Mattos e pediu-me para sêr da companhia. A eu ir, teriamos de addiar a tua visita para 6. ${ }^{a}$ ou sabbado. Custa-me muito, mas lembro-me ao mesmo tempo que as tuas visitas se não podem repetir muito, e que é melhor esperar a festa que têr saudades d'ella. Manda-me dizer o que queres e decides, para eu procedêr segundo o teu desejo e determinação. Estou na baixa porque tive de tratar de coisas e fazêr horas para uma visita.

Teu

A. S.

Minha Luisa:

[Agosto] (1909)

São 10 e meia da noite, escrevo-te de casa da Mathilde. Vim acompanha-la desde a minha até aqui, porque foi para lá seroar. Eu entretanto, desde as 7 até agora estive na sala palestrando com o Sr. Dr. Henrique Vilhena. O Dr.[?] Henrique Vilhena é um professor da Academia de Bellas Artes que acaba de publicar um trabalho muitíssimo paciente, muito erudito, muito honesto sobre a Expressão da cólera na literatura. Homem que não é um muito grande talento, mas um inteligente, sério, simpático, honesto, infatigável trabalhador. Escrevi-lhe duas palavras de aprêço, - e o digno homem de tal maneira ficou grato que logo no dia seguinte me foi procurar 
a casa, vindo ao todo 4 vêzes sem me encontrar. Finalmente hoje à tarde resolveu-se a ficar na sala mais de uma hora até que eu viesse. Como não appareci, retirou deixando-me recado de que voltaria às 7. Veio, foi muitissimo simpático, immensamente amável, e palestrámos sobre tudo e mais alguma coisa durante 3 estiradas horas: arte, filosofia, historia, critica, religiões, o diabo. Somos dois espíritos egualmente sinceros e abertos, mas elle caminha a pé, pacientemente e seguramente, accumulando factosinhos: «sou todo paciência, e só paciência», me confessou com simplicidade. Eu devia têr-lhe feito uma impressão estranha, com os meus saltos, as minhas rajadas, os meus voos, as minhas largas ideas geraes suggeridas em dois traços. Ficámos amigos. E a propósito, tive hoje coisas muito lisonjeiras, que depois contarei.

Escrevi-te um cartão postal esta tarde. É uma simples consulta, decide tu como quizeres. O Mene tem empenho em que eu venha, mas não se perderia o Universo se não viesse.

As noticias que me dás são muito alegres. Pena é a estação. Em ires não devemos pensar, porque não vou para estar num ponto, mas para girar, além de mil outros inconvenientes de detalhe. Casarmos dentro de seis mêzes seria em si um Paraíso Terreal, mas lembra-te que eu partiria e ficarias viuvinha por dois annos logo três dias depois do casamento, o que era mil vêzes mais custoso e estupidíssimo. Perante isto (maldita marinha!!) talvêz a melhor solução seja ainda esperar os dois annos, - e não calculas minha pequenina, com que aborrecimento, com que confusão, com que desespére o digo. Se eu pudésse sair d'esta carreira!... Mas voltando, ás circunstâncias reaes, a estação, os dois annos d'espera, teem ainda a vantagem de me permittir accumular um magríssimo pecúlio para a casa. S̃̃o estas, minha pérola, as tristes mas positivas realidades...

Adeus, noivasinha, a Mathilde quer naturalmente deitar-se e preciso de te escrevêr a corrêr. Quando poderemos falar de tudo isto e mais, sem sêr ao maldito telefone, bicho do progresso com que sempre embirrei, sendo preciso havêr uma Luch para eu me rezolvêr a usa-lo?

Adeus. Hoje ainda tive uma esperançasita de te encontrar na baixa. Sempre poderia sêr que te tivesses resolvido a sair para qualquer coisa. E depois, não sei se seria maior o prazêr de te vêr se a raiva de não podêr ir para o pé de ti. Mesmo quando te falo, metade de mim mesmo está na preoccupação da $D$. Crítica, do protocolo, do frio que em mim produz a simples presença de um estranho. Eu que tão pouca importancia dou a Suas Ex. as quando se trata de mim só! Adeus, adeus, a Mathilde já me deve estar rogando pragas.

Teu, teu e teu

[Agosto 1909]

Minha Luisa: Se fosse eu a correspondêr-me com o Provedor da Misericórdia, estava muito bem, porque ha já as fórmulas consagradas a que a gente se deve submettêr em todas estas coisas officiaes e semi-officiaes. Para damas é que não ha fórmulas consuetudinárias: que havias de pôr antes da assignatura? - o melhor é talvêz não pôr nada. Saiu-me esse rascunho que mando, e que não sei 
se te agradará. Faze em uma folha grande de papel de linho, ou coisa parecida, com a dobra que vae indicada.

Não te arrependas de mandar cartas como a de hontèm, porque gostei muitíssimo d'ella, assim como dos «impetos de paixão», como lhe chamas; falavas melhor do que na de hoje, porque estavas mais profundamente emocionada. Nada melhor do que sentir, por trás das palavras, uma criatura verdadeira e viva.

Se te não mandei a minha, não foi talvêz tanto pelo tristonho, como pelo pedido, ou antes pela hipótese que suggeria, de ires a minha casa com a miss. E porventura melhor não pensar nisso, não e verdade? E demais, já podemos têr na segunda-feira a indemnização em que naquelle momento eu sonhava, - um instante em que te pudesse falar nos nossos planos e na nossa vida.

Se continuas com essa assiduidade ao animatógrafo, arranjas uma doença de olhos; será melhor não dar muita attenção ao espectáculo. Manda-me dizêr quando queres que nós vamos também, e a hora. Seria melhor que fosse um bom, mas pouco concorrido.

E meia-noite, minha Luisa, e cá estou nas coisas do costume. Se eu effectivamente pudesse arranjar qualquer coisa que me livrasse finalmente de passar a vida nas Guinés, Angolas e Moçambiques, longe de tudo, entre uma gente absolutamente alheia a tudo que me interessa, num meio que me não deixa sêr quem sou, ruidoso, mexido, pequenino! A vinda para esta profissão foi um suicídio moral. Paciencia, paciencia! Não falta quem me diga que sou o homem mais feliz d'este mundo, e que Nosso Senhor me deu tudo... Daria, daria, mas tira-me o meio de o gosar, ou por outra, tireim'o eu a mim mesmo com uma rezolução que me foi suggerida por toda a minha vida em criança, passada em navios e entre officiaes de marinha. Quem me diria, aos 16 annos, que havia de sêr quem sou aos 25? Ora, a raça dos lamentadores é aquella com que eu mais embirro depois da dos vaidosos: portanto, escorropichemos do Collares, e um viva à rainha Jacintha. Como ao outro, plantem-me sobre a cova uma vinha, - para que possa dar ao mundo, depois de morto, uma parte do vinho que lhe bebi.

\section{A. S.}

[13-8-09]

Sexta-feira, 10 da manhan.

Escrevi-te hontem á noite, minha Luisa, uma carta tristonha que tencionava mandar hoje para o correio. Já agora vae antes este cartão postal. Fiqquei muito desapontado, porque formára um lindo plano de podêr conversar á vontade comtigo sobre as nossas coisas. Tudo em fumo. Paciência. Depois de saires fiquei tão vasio que saí também, á toa, e fui dar ao Calvário. Quando te tornarei a ver?

Convir-te-ia um andar, Direito e Esquêrdo, em que morássemos com a minha Mãe e a Pilar, como succede em S. Paulo com a Ruth e as tias? Já podia sêr uma casa mais pequenina porque tomávamos conta de parte da d'ellas. Se eu fosse para a Guiné talvez me pudésse demorar menos que os dois annos, e tu com a Pilar escolhiam cá a casita, ellas mudávam-se, mobilavam e arranjavam a nossa, de 
maneira que ao desembarcar estaria tudo prompto e era só ir para a Igreja... Escreve-me, cordeirinha, e dize se isto poderia ser, e se te é fácil desistir da Rua Antonio Maria Cardoso. Um enorme, amantíssimo abraço do teu muito fervoroso

A. S.

P. S. A Pilar está triste porque tens sido pouco amorosa com ella. Não lhe respondeste á carta.

Minha Luisa:

[14-8-09]

Sabbado, 9 da manhan.

Muito e muito grato pela tua cartinha. Fizeste muitíssimo bem em m'a escrevêr, e repete sempre que pudéres. Chegou-me minutos depois de eu mandar o meu cartão para o correio, em logar da tal carta.

Podes crêr, meu amor, que não passei uma noite menos triste e aborrecida do que tu; também para mim teria sido melhor que não viesses, porque não haveria o desapontamento que tivemos.

Combina com a Pilar a hora em que devemos ir à tia Helena. Espero que terei agora carta no quartel, respondendo ao meu cartão.

Vê se consolas e animas o mais possível a Pilar, que tem andado muito abatida com a idea da separação; agora, para a Guiné; e depois, para ti. Pergunta-me várias vêzes se nós a não esquèceremos, se eu gosto muito mais de ti do que d'ella, etc., etc.. Ficou muito triste com o não lhe responderes à carta. Tem, coitada, a maior vontade de sêr verdadeiramente tua irman, e de procedêr e sentir como tal, mas teme muito que tu não correspondas com igual boa vontade. Depois, ha quem lhe faça muita festa, e d'ahi comparações que a desanimam. Vê portanto se consegues desfazêr hoje todos os receios, desconfianças e abatimentos.

Não tenho a certêza se ficarei no quartel hoje, ou não. Se afinal tiver de ficar só amanhan, posso eu mesmo ir buscar a Pilar, se assim quizeres. Combinarei com ella pelo caminho.

Hontem fomos á tia Maria José (Rua da Escola do Exercito) e depois á Julianna, que passára mal. Encontrámo-la bem, e o Roberto, que lá jantára, desafiou-nos para a feira de Agosto. Era para mim a primeira vêz. Coisa muitíssimo abaixo do que devêra sêr. Joguei uma duzia de argolas ás garrafas, e ganhei uma, de vistosos rótulos dourados: "Clarête tinto do D. Fulano de Tal, fornecedor de Sua Majestade, taes premios em taes exposições». Chegámos a casa quasi á meia noite. Junto de uma barraca a Pilar perguntou-me: «E se encontrássemos agora a Luch?» Eu, francamente, não estava a pensar nisso, porque me não parecia nada possível. Adeus, minha joia, até segunda-feira

A. S. 
Minha Luisa:

s. d.

Por várias razões não me foi possível escrevêr-te antes de agora, que é $1 \mathrm{H}$ da noite: fica pois a carta ao teu Pae para amanhan. Hontem o infame tremor de terra acordou-me às $3 \mathrm{~h}$., e como de costume, uma vêz acordado não consegui dormir mais; como este sistema dura já ha um tempo a somno curto, estou positivamente a cair. E lembra-me que ás $5 \mathrm{~h}$. tenho cornêtas, alvoradas, barulho! Uma verdadeira tortura. Isto só com cabêças de pedra, a fogo lento, modorrentas, como teem a maioria dos meus camaradas. Para mim é um martírio.

Não sei se te desagradou a minha reluctância em lá ir antes de me intendêr com teu Pae: parece-me desta forma mais correcto, menos abusivo, e elle naturalmente assim o achará. Como sabes, custa-me infinitamente o sêr molesto a alguém, e d'esta maneira parece-me que já o poderei sêr um nadinha menos. Tenho muita pena de que isto succéda depois de já têres pedido e obtido a licença, mas emfim, talvêz valha a pena o contratempo.

Adeus, minha pequenina, até quando pudér sêr. Mil saudades muito affectuosas do teu marido

A. S.

80

[19-8-09]

Minha pequenina:

São seis e meia da manhan, vou para o comboio muito bem disposto e muito bem dormido. Hoje deve ir um portador lá a casa levar a carta para teu Pae. Escreve para eu recebêr amanhan no quartel. Se a Pilar quizer, levo-a de caminho a passar o dia comtigo.

Teu e muito teu

A.S. 


\section{CARTA DE ANTÓNIO SÉRGIO A MANUEL JOSÉ DA SILVA}

Ill. ${ }^{\text {mo }}$ e Ex. ${ }^{\text {mo }}$ Senhor

Manoel Jozé da Silva

Rua Antonio Maria Cardoso, 24, 2. ${ }^{\circ}$

Ex. ${ }^{\text {mo }}$ Senhor Silva da minha muita consideração:

Sei que sua Ex. ${ }^{\text {ma }}$ filha lhe falou de assumpto que nos diz respeito:- e parece-me que já agora é devêr meu falar também. Não tenho que lhe fazêr a minha apresentação, porque honrando-me ha já bastante tempo com a sua amizade e os seus obsequios, me conhece perfeitamente; lamento-me de não têr uma menos modesta situação social, mas nesse ponto, como julgo que também sabe, não me accusa a consciência de me não têr a mim mesmo combatido suficientemente espero também que me fará a justiça de acreditar que esquèci e esquècerei o que me diz respeito para só olhar ao interesse, ao bem-estar e á vontade de sua filha. Como se avaliam das árvores pelo fruto, aquilatam-se os homens pelas acçôes e pela vida: tem todo o direito de sêr com as minhas exigentíssimo, e eu todo o devêr de lhe pedir que o seja. Em breve seguirei para África, onde me demorarei um, ou, o máximo, dois annos; depois de chegar procurarei conseguir uma situação mais estável e supplicar-lhe, se m'o consente, a união que muito me honraria. Receberei onde, e quando mandar, as suas ordens. Podia-lhe agora falar, não é verdade? com firmes promessas e fervorosos protestos sobre a qualidade dos meus sentimentos, - mas creio que, como eu, dá muito mais valor a factos do que a discursos, e julga bem o que as palavras valem: um pouco menos do que nada. Resta-me pedir-lhe que me creia, como realmente sou,

Seu muito grato, venerador e respeitoso

Antonio Sergio de Sousa

82

[20-8-09]

Minha Luisa:

Quinta-feira, 11 da noite.

Cheguei agora a Lisboa. Passei bem. Passeio no Sado em canoa, maravilhoso banho de mar, musica no passeio á noite, almoço e jantar com a mana Emilia do Amor de França. Muitas saudades do teu

A. $\mathbf{S .}$ 
Minha Luisa: Pidida a mão de Quinota. Muito bem. Acabámos com um abraço, e elle com lágrimas. Já vês que o menos sensível... sou eu! Tratámos da coisa como dois diplomatas $e$ como dois amigos. «Que eu, é claro, não ia contar com têr que recorrêr e andar a pedir a elle...» Cara minha de absoluto e categórico assentimento. "Que eu me não melindrava, mas bem via as coisas...» Pois então! Lemos pela mesma cartilha, entendemo-nos perfeitamente. Ficou combinado eu tê-lo ao facto das coisas que me conviriam, e que lá iria passar a noite de terça-feira. Vou vêr o João.

Teu A. S.

Acabo de chegar a casa, tendo tido uma conversa com o almirante Capello, que me marcára entrevista para esta noite. Parece que a ida para a Guine se arranja. Parto provavelmente a 4 de Novembro.

Mandas-me que conte miudamente os acontecimentos com teu Pae. Cheguei, sentámo-nos fronteiros, disse-me que me queria ouvir. Que tençõ̃es tinha? Respondi o que sabes. Teve a palavra: «eu sabia perfeitamente que os meus 60 e tantos mil reis não são nada, que nessas condições não podia pensar em formar familia, etc., etc., etc. Seria preciso arranjar pelo menos o dobro d'isso: como tencionava consegui-lo?» Declarei, que primeiramente, não abandonaria a marinha; tentaria arranjar uma commissão da arma. Approvou. No professorado era impossível pensar, porque ainda não sou primeiro-tenente. Além d'essas ha, eommissões especiaes, os observatórios. Está o pessoal cheio, tenho de esperar vaga. Vencimentos, não sei, vou indagar. Ha mais outras eommissões especiaes, mas nada d'isso se pode precisar com dois annos de antecedência, ou com um. Ficou combinado que eu indagaria com tempo, e o iria prevenindo do que encontrasse conveniente.

(Aqui para nós, arranjáda a commissão especial, eu poderia ganhar muito soffrível e facilmente quantia superior a aquella se desistisse de vêz do pensamento, da arte, da cultura. Mas antes d'isso quero tentar obtêr a coisa sem essa desistência. Vamos a vêr).

Continuando. Dizia teu Pae que eu não podia pensar, certamente, em lhe pedir a elle. Este ponto é que deveria estar, desde princípio, implicitamente admittido sem discussão. Mas foi, também, uma observação fugidia e leve. Esteve amabilissimo commigo, disse que levava a bem a tua escolha, que visto eu sêr tão bom filho bom marido havia de sêr também, etc. Que não tinha que me melindrar com esta historia dos vencimentos, porque eu não tinha culpa de sêr pobre e de elle têr mais alguma coisinha, etc. Encontrou, e devia esperar encontrar, homem que visse o assumpto com a positividade que elle requer. Foi perfeito de amabilidade e quasi perfeito de estilo. 
Ora, como sabes, o estilo, o modus faciendi, todo composto d'esprit de finesse é a coisa mais difficil e rara neste mundo ...

Falou vagamente, e com muito tacto, na questão da casa; achou muito rasoáveis todas as minhas palavras, concordando sempre plenamente; convidou-me a ir lá a casa todas as semanas, explanando considerações muito sensatas; convidou-nos outrosim para o dia 4, gentil, finissimamente; e acabou com o abraço do estilo e as lágrimas que te contei...

Adeus, minha querida Luisa, falando poderei satisfazêr melhor a tua curiosidade. Vamos a vêr, vamos a vêr... Até lá, ama quanto puderes o teu marido, que te manda um grande, grande, profundo e amoroso abraço.

\section{A. S.}

Minha Luisa: Como te já disse, teu Pae foi encantador commigo; - mas fiquei com a impressão de que elle não conhecia perfeitamente como as coisas se passaram. Deprehendi julgar que eu, levado pelo natural enthusiasmo d'estes casos, (palavras suas), via facilidades, e via facilidades, naturalmente, por contar com aquilo corn que não contei. Não sei se me comprehendes. Tu, querendo apressar e simplificar as coisas, dás-me uma bella prova de affeição, mas apresentas-me a teu Pae com uma figura triste, pouco digna, e tanto mais triste quanto é falsissima. Eu, minha Luisa, já não estava com coragem de te contrariar: ia-te dizendo que sim, mas intimamente convencido de que as demoras haviam de ser maiores. Repara nisto, meu amôr: que, como te já disse, acima de tudo, de tudo, devo procurar que não possa havêr más comprehensões sobre a minha maneira de encarar o problema. Quasi me indignavas quando me dizias que este ponto era secundário, quando para mim sobreleva infinitamente todos os outros; uma vêz, ao telefone, não pude vencer uma certa vivacidade na resposta, - em que tu reparaste, e me fizeste sabêr que reparáras. Ora, é triste que eu tivesse estes cuidados para agora parecêr que os não tivéra. «Fama sem proveito faz mal ao peito», e as preoccupações não são tão poucas que se despreze o fruto que podem têr: conservar illesa a nossa modesta dignidade. Só havia para nós dois caminhos: descêres até mim, ou eu subir um pouco para ti, - economicamente falando. Ora, sabes que a segunda hipotese estava absolutamente fóra da verosimilhança nos meus cálculos. Mas, dir-se-á, nesse caso eu ia sujeitar a minha mulher a sacrificios, etc. A resposta é, que porisso mesmo estive tanto tempo sem admittir a possibilidade de casar comtigo, e porisso mesmo foi a primeira coisa em que depois falei, - e constantemente repeti. Hontem, no escritório, por natural delicadêza não insisti neste ponto. Não era momento de parecêr renegar-te, desapprovando perante elle os teus planos rápidos. Mas preciso de que teu Pae se inteire bem das circunstancias: sempre achei necessárias as condições que elle intende, o dobro do que tenho hoje. Cá em Lisboa, dentro da marinha não é fácil arranja-lo para breve, e portanto a solução é a que te sempre disse: esperar, dar tempo ao tempo. Se soubesse como as coisas se passa- 
ram, se pudesse lêr alguns períodos das minhas cartas!... Meu amor, estamos cada qual no seu papel, mas tu não deves exagerar o teu, porque dás triste idea do teu noivo...

Helas, je compte les ombres

Quand tu comptes les clartés!

Sabe elle bem isto? Não sabe. Não sabe e é preciso que o saiba, - elle e todos.

Perdoa este discurso massudo, e não te esquèças de sêr muito gentil com teu Pae, que o foi extraor dinar issimamente commigo. A Pilar lá estará ás 10 horas da manhan a batér-te á porta. Se te vir, espero encontrar-te tão bem disposta como eu estou. Começa desde já a sêr misericordiosa com as imperfeições do teu marido, que te ama muito, e que muito devotadamente te beija as mãos

A. S.

[23-8-09]

Minha Luisa, stella matutina, turris davidica, janua coeli, etc., toda a ladainha, ores ou não por mim. São seis da tarde, acabei de jantar, escrevo-te agora porque tenho mêdo de logo á noite me sêr difficil. Ficam-me remorsos não te escrevendo, apesar de que amanhan... faço a primeira visita á minha Luch na qualidade official de seu noivo. Cáspite! Pois então? Noivinha «de verdad»: Parece-lhe a V. Ex. ${ }^{a}$ um sonho?... Muito me conta! «É o noivo da minha filha e portanto...» disse teu Pae ante-hontem. Como te já escrevi, falou-me incidentemente na casa. A propósito de não sei quê da minha familia, - «eu não tenho nada com isso é claro, insinuou, mas naturalmente pensa em vivêr com sua Mãe...». Respondi que no mesmo prédio, ou visinhos, e não sei se elle reparou bem em que ficaríamos separados d'ella, com casa àparte, pela mesma razão por que nos separaremos d'elle. Se não ficou inteirado, tu lh'o dirás. Mal calcula quanto me custa o pensamento de lhe têr que tirar a sua filha!

Oxalá, pomba minha, as malditas finanças nos não obriguem a demorar muito. Se obrigarem, far-se-á tudo de cara alegre. Saberás apreciar e comprehendêr a maneira de sêr do teu irmãozinho, não é verdade? Dizem que sou um homem só feito de intelligeneia, porque me não manifesto em grandes frases, em grandes gestos, em carícias espumantes. Sou simpes e puro, eis tudo. Reduzi-me completamente a uma alma, recatada, íntima, a uma chamma direita, sem turvaçoes e faúlhas, transparente e muito clara. Gosto que me chames pequenino, porque sou realmente pequenino na minha affeetividade, pequenino como uma criança. Estava hoje a satisfazêr-me em te espremêr as mãos, como tu ao corpito do Antoninho. Sou nisto tão infantil como precocemente grave e velho na minha vida e no pensamento. Gostava de que fosses também assim, para me não estranhares a extravagância...

Porque te ficou de memória o que te disse em casa da tia Helena, - que me dava ás vezes vontade de uma coisa que á falta de outro e melhor termo chamei dormir, quer dizêr, sentir corrêr a vida sem angústia, como uma linha de água nos meandros de um jardim florido? Sentes também assim? Deixar corrêr, deixar corrêr... Achas também que não ha prazêr mais puro, nem mais bello, nem 
melhor, nem mais suavemente intenso do que pegar nas mãos de quem se ama, - e deixar esquècêr o resto, e deixar fugir as horas? Dormir, dormir... Porisso eu gosto tanto das tuas mãos, minha Luisa, ponsso eu gosto tanto d'ellas: porque me conduzirão assim a vergeis em que repouse. Muito consolado de tudo que é mau e malperfeito, sentir-se levado, embalado, descansado. Dormir, dormir...

Adeus, Luisa, estou-te a dizêr asneiras. Até amanhan. Oxalá nos sintamos bem. Adeus. Tenho de ir vêr uns homens que saém para uma guarda. Espreme-te muito o teu irmãozinho que te odeia cordeaimente

\section{A. S.}

\section{7}

[25-8-09]

Minha pequenina - Tive um sonho que vaes achar exquisito: eu era cego; guiava-me a Pilar, e dizia-lhe: «leva-me para onde está a Luisa, leva-me para onde ella está...». Ella procurava-te, sem te encomrar, e eu seguia atrás, de mão dada, subindo umas escadas: tu devias estar no cimo, lá no cimo....

Está um dia maravilhoso, e penso alegremente em ti. Gostei muito da noite de hontem, e tiveste uma idea adamantina em apparecères d'aquelle vestido. A tia Helena, ao despedir-se, á tua porta, expandiu-se risonhamente. A Pilar te responderá sobre amanhan.

E o mano João? Coitado, lá teve de aturar a estopada. Agradece-lh'o. Ponho ponto para não fazer esperar o Senhor Ricardo, cujo retrato ainda não vi: não tens comtigo o desenho original? Naturalmente não, nem terão talvez feito a gravura ainda.

Um abraço como um raio de sol do muito teu

A. $\mathbf{S}$.

Minha cordeirinha que eu amo------- quanto? Não sei, pequenina, seria preciso inventar uma palavra nova. $E$ tu sabes isso, não é verdade? Adivinha-lo quando t'o não digo, e sente-lo perfeitamente se t'o digo.

Preciso de passar pela baixa antes de ir para o Quartel, e porisso aproveito metter um bilhetinho na Posta interna. Accordei muito cedo, e a pensar na sabbado, que espero com uma impaciência de que te não posso dar uma idea se a não sentes tanta como eu.

Infelizmente a Pilar não podia ir hoje porque vêem cá a tia Maria José e a Adrianna.

Adeus, minha Luisa, ando fóra de mim porque estou sempre comtigo, e já não sei pensar senão em ti. 
Deu-me muito prazêr a tua carta, minha cotovia, que me vieste cantar pela manhan, e segundo me dizes, alegre como um passarito. Hontem à noite houve uma pequenina coisa que me apoquentou, mas hoje acordei com o pensamento de que o meu amor por ti é uma riqueza bastante grande para me fazêr contente apesar de tudo, seja o que fôr. Li algures que o amôr é como um templo que se eleva a quem se ama: - como a verdadeira felicidade está em se amar, muito antes que em se sêr amado, vale mais a capella que o deus, ou antes, verdadeiramente sublime e bom é a construcção do templo, o carinho com que se guarnece o altar, o enlêvo com que se exerce o culto. Não sentes isto, meu amôr, e não tinha eu razão de te dizêr outro dia que te devia lamentar se fosse eu quem mais amasse?

Nisto, eu é que com certeza não mereço lamentações. Penso em li, minha Luisa, como se pensa numa aurora que illumina tudo. Ando, respiro, falo, leio, converso, mas entre todos os pensamentos, todas as palavras, todas as acçÖes, mette-se sempre por um momento a tua imagem, como entre as folhas de uma floresta apparece o firmamento. De vêz em quando posso entrar em campina raza, $^{\wedge}$ e não vejo senão tu, como se estivesse em pleno oceano, e o mar fosse tu e o ceu tu também. Se é muito bom o sêr-se amada, alegra-te muito, muito, muito, repete-te a ti mesma que és feliz, expande a tua alegria pela luz, pelas flores, pelas águas, pelo mundo!

Não te tenho perguntado pelo estudo porque tens tido muitas coisas em que pensar agora, e não queria sêr importuno ou desconsolar-te, obrigando-te a confessar que pouco lêras. Dás-me uma intensa e profunda satisfação ligando importancia a este ponto. $O$ grande divino amôr é o que liga dois corações e duas intelligencias. Eu por mim faço quanto posso, promptificando-me a dedicar a minha attenção a assumptos que possas comprehendêr bem e que te possam interessar. Pareceu-me que a arte é o que ha de mais próprio para ti, mas se vires que assim não é, escolhe outro. Não desanimes com as difficuldades, porque as ha para todos ao principio, emquanto se não está senhor de um certo número de factos, de algumas maneiras de vêr, etc., emquanto, emfim, se não conhece bem o nome aos bois. Depois tudo se facili...** Arago, um grande astrónomo e matemático, dizia que quando em estudante encontrava um ponto que não comprehendia passava adiante, e mais tarde, ao revêr e repetir, se admirava sempre de não têr comprehendido uma coisa tão fácil. Assim te succederá a ti. Quasi sempre será de não sabêres bem o valor de certas palavras, que conheces na sua significação geral, mas não particular e precisamente. Estuda quanto pudéres, meu amôr: mais tarde verás que bom conselho é este, que grande consolação, que grande thesoiro, que grande fonte dos mais puros prazêres são as ideas que se trocam entre duas almas, os pensamentos que respiramos e vivemos, os livros que se discutem, se absorvem, se commentam. Depois saberás, quando aprendêres a apreciar a belleza da música intellectual, dos movimentos, dos sistemas de concepções, quanto as ideas reflectem nas almas que as frequentam, a divindade que lhes é própria.

* Rasgado no original 
Veio-me hoje á cabêça esta frase, que me agradou: duas criaturas que bem se amam formam $u m$ anjo no ceu. Um anjo! Que me dizes? Pensa nisto, minha pequenina, e tem uma firme, assidua, inquebrantável vontade de formar desde já o anjo. Podes crêr que seria impossível encontrar em todo o universo quem mais seriamente o quizesse tentar do que eu comtigo. Parece-me que isto resgata, minha Luisa, todos os defeitos que eu possa ter, e me faz digno de me amares com um amor enorme, sem restricções, sem desíallecimentos, sem limites. Por mim, deixa-me dizér-te uma vêz por todas que te amo o mais verdadeiramente, e bellamente, e santamente que é possivel.

E sabbado? Não tenho sonhado com outra coisa. Sempre poderá sêr? Não obtivemos ainda o indispensável convite da tia Helena. Deus queira não surja qualquer inconveniente. Leva o Breviário para me mostrares, não te esqueças .Sim? Não te esquèças.

Recebi hoje um bilhete postal do França, que está em Santarém. Pergunta-me o que ha sobre a minha ida para a Guiné. Hontem recebi uma carta do Capêllo dizendo que o logar já estava promettido a um rapaz Rebello, mas houve engano, porque esse não pediu o que eu pedi. Não deverá portanto havêr grande difficudade.

São três horas da tarde. Escrêvo-te agora porque por felicidade as coisas se arranjaram de maneira a estar agora livre. Tenho hoje exercício de infantia, o que me fará deitar tudo para mais tarde. Ao vir para o Quartel deitei um cartãosinho na Posta interna. Acho muito cómodos e práticos os taes cartões. Mais uma vêz te peço que não olhes ao comprimento das cartas. Se te escrevesse proporcionalmente ao que penso em ti, não tinha tempo para outra coisa, e se me deixasse vencêr pelas saudades já tinha adoecido de desespêro. Minha noivasinha, quando te poderei eu guardar de vêz, de mim, commigo, para mim? Quem me déra no sabbado, quem me déra no sabbado! Penso com angústia em que possa vir alguma difficuldade, ou mesmo alguma demora, como outro dia. Luisa, minha, minha Luisa!... O teu marido está mais unido a ti do que o meu coração ao meu peito. Amo-te, e não sei dizêr quanto te amo. Não se póde medir, não é verdade? Mas sei dizêr-te como, e já t'o tenho dito. Minha, minha pomba: mando-te num beijo toda a bellêza das minhas aspirações, todo o meu idealismo, toda a minha alma -

\section{A. S.}

P. S. Da ultima vêz falei-te muito sêcamente ao telefone porque tinha gente ao pé de mim. Podíamos combinar uma frase qualquer que eu dissesse para te avisar nessas occasiões.

Minha Luisa que muito amo: Que bom me soube, meu amor, que bem, que bem, que bem, a noitesinha de hontem! Como já estavam as coisas sabidas e tratadas, parecia-me que não só as pessoas, mas os próprios moveis, sabiam, concordavam, approvavam. Senti-me 


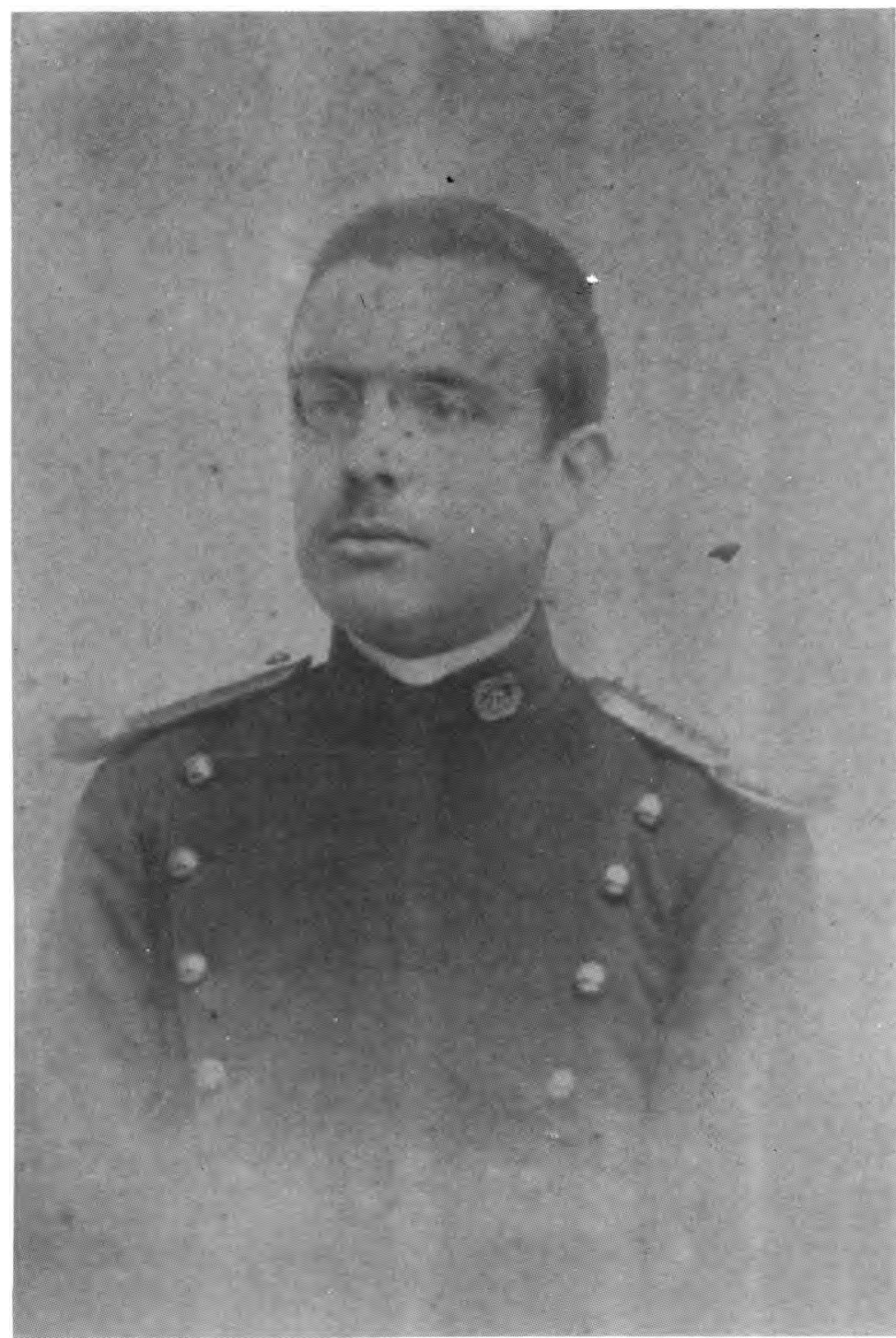

Eduardo Augusto de Oliveira Pessoa, cunhado de Antonio Sérgio (casado com Juliana) e a quem este chama «o Cavalarias» 
(Página deixada propositadamente em branco) 
casado comtigo, e pódes talvez calcular por ti a impressão doce, repousada, que essa impressão me fazia. Era como alguém que fugindo a um temporal se sentisse acolhido e aquècido e agasalhado sob um tecto protector; a tua casa era uma ilha, - e tudo mais um torvo mar que ali parasse.

Veio-me a Pilar dizêr que teu Pae perguntara porque nos retirámos tão cêdo. Antes ache cêdo que o contrário.

Tenho passado o dia, - escrevo-te pela tardinha, - tenho passado o dia a arrumar papeis. Entre esses papeis, tirei os sobrescrites $L$ empacotei as tuas cartas - meu amôr!-e guardei-as numa caixinha. Pediu-nos a Mathilde que fossemos passar a noite a casa d'ella, e é o que faremos. Toto corde tibi prostratum.

[27-8-09]

São, minha Luisa, quatro horas da manhan, e penso, penso, penso em ti. Cada vêz me é mais difficil o estar sem o meu amôr, cada vêz penso com mais angústia na despedida. Está uma noite doce, um pouco húmida, muito escura. $O$ ceu parece um manto de veludo negro bordado a pontos de oiro. Mesmo ao Sul, alto, grande e immóvel, Jupiter, que não conheces; por cima da tua casa Aldebaran, Orion, Sirius, a mais brilhante das estrellas. Porque não heide eu estar comtigo, minha pequenina, para te dizêr que te amo como um doido?

Só mandarei pôr este cartão no correio amanhan pelas nove horas, para que o não recebas ao mesmo tempo que a carta, e possas têr à tarde uma surprêza. Espero pelo sabbado como pela entrada no Palacio da Grau Ventura. Uma grande saudade até lá. Mil vêzes mais teu do que meu próprio

A. S.

Minha garçazinha branca: Não te mandei resposta pelo Ricardo porque não estavas de dia em casa para a recebêr, e de noite deves encontrar lá o cartão que mandei pôr no correio esta manhan.

Deus permitta que durmas óptimamente, minha amada muito amada, e que acordes muito bem disposta para um dia felicíssimo. Por sorte chegaram-me uns livros novos a que me atirei quanto pude para distrair a minha impaciência, e para abrandar as saudades de certa imagem, que fluctua nos meus olhos...

Adeus, minha pequenina, nem te posso dizêr o que sinto quando penso em amanhan. Não te esquèças de levar o Breviario.

Teu

A. S. 
Minha Luisa: Ia-me deitar quando me arrependi de te não têr escrito para recebêres de manhan. Tencionava escrever só amanhan, para te chegar à tarde. Mas ficou-me a remordêr a idea de que terias às $9 \mathrm{~h}$ um desapontamento... Mil saudades do todo teu

A. $\mathbf{S}$.

Quem hontem merecia receber parabéns era eu e não tu: a tia Helena deu-m'os...

Acordei como sempre muito cedo, mas se tenho certa somnolencia estou em compensação muito bem disposto. Tu dormiste pouco certamente: deves evitar isso, porque não estás como eu acostumada e não tens muito provavelmente uma resistencia á fadiga como a minha quando conservo o espirito e os nervos afinados. Não deverias têr-te levantado: duas palavras escritas hoje pela manhan e mandadas pelo Ricardo não valiam menos que uma cartinha atuchada: não se medem expressões amorosas pela quantidade, principalmente sabendo eu que te escasseava o tempo.

O teu presente é um mimo. Metti-lhe hoje pela manhan o Taine, porque a Pilar se queixou tristonhamente de que eu não dera a mesma importancia ao d'ella... Todos se queixam de mim, e vejo que sou uma fera. Não sou, mas divertem-se a exprobar-m'o como se o fosse: tu é que o és, porque me accusas sabendo que o fazes sem razão. Luisa, minha Luisa: porque não procuras tu mesma justificar-me? Se o caso se desse com outro e com outra, hontem, tu approva-lo-ias altamente, e criticarias o contrário. Lembra-te de que as pessoas que estão de fóra vêem forçosamente as coisas por outro prisma, e teem para comnosco exigências exactamente contrárias ás do nosso coração.

Gostei muito das tuas primas: o peor era que ellas só falavam para respondêr com nitidêz e concisão ás minhas perguntas, de maneira que a conversa parecia uma inquirição judicial, e começava a entrar na bisbilhotice. $E$ o tio? (Augusto? Alfrêdo?...). Um caturra muito simpático. Falta-lhe a aduela da energia prática. Estuda a' linguas simplesmente pelas linguas, sem as usar depois como instrumentos, que é o que ellas são. Isto caracteriza um homem. Os d'aquella especie, tendo muitas qualidades são incapazes de uma obra, porque o pôr uma obra em pé é sempre um acto de energia, ( — digo uma obra de pensamento). Estão para o sabio como o colleccionadốr de borbolêtas para o naturalista. Encantadores como as crianças, porque são infantis.

A tia è o tipo da mãe de familia mimosa e venerável. As filhas são como rebentinhos novos, tenros, tenros... A familia dava para 
um d'estes romances inglêses de edificação moral, cuja acção corre como uma arroio, que nos arrancam pelo meio uma lagrimazinha suave e fugidia, e veem a acabar em alegrias transparentes.

A tua amiga Maria é outra classe de gente. Já não um rebentinho, mas um tronco frondoso que balança ao vento. Tem mais paixão do que mil das outras; o romance poderia sêr de fulgurações. Emquanto teu tio não é pratico por falta, a tua amiga poderia acaso não o sêr por excesso. Eu me explico: nem todos chegam cêdo á conclusão de que o ideal não deve pairar no ar como um balão, ou, pelo menos, sempre no ar. $O$ primeiro contacto com a terra amachuca-o; mas mas devemos lembrar-nos depois de que elle é mais util se descêr à realidade, para dar e levar, apanhar o seu encontrão e respondêr. Uma boia tem a sua âncora bem firme no fundo, baloiça com cada onda e não foge do seu logar. Quando veem as decepç̃es a gente não pensa nisto, mas a verdade é que tem de sêr assim. Sc uma coisa me parece irremediável: a indignidade de alguém que amamos muito. Nem mesmo é precisa a verdadeira indignidade: lembra-te do Vase brisé do Sully Prudhomme.

Entre parenthesis: a prima mais velha pareceu-me differir muito das outras duas: é certo? Como sabes, não consegui ouvi-las, falo só pelas caras.

Minha Luisa, porque exiges que te diga que te amo, quando tens maneira de sentires que assim é? Não repares de te não escrevêr sempre muito. Pareço que não faço nada, porque não sou espalhafatoso, mas olha que não é assim. Vou-te dizêr como tenho gasto o meu tempo nos ultimos dias. Tive visitas de dia do França, do Pessoa e Julianna, do Mene, etc., em dias diversos. Não posso deixar de estar a dar-lhes conversa. Nos dias em que saio do serviço não chego a casa em geral antes da uma hora. Um dia perdeu-se em casa do Chagas, onde fui almoçar para vêr uns artigos sobre marinha que elle está publicando. Outro dia tive de ir á Biblioteca da Escola Naval, vêr umas coisas indispensáveis. Tenho tido que tratar de uns negocios de uns marinheiros: uns querem entrar para marinha, outros vão respondêr a conselho de guerra e teem não sei que pretensões, etc.; estes querem passar de navio, aquelles mudar de classe. Âs vezes são recommendados por pessoas que se offenderiam se se lhes não dá attenção. Não durmo em media mais que quatro horas por noite, e as noites do quartel são muito más pelo esforço de estar acordado e depois pelo barulho, passagem de gente, luzes, de maneira que é sempre um somno muito fraco. Pois agora exactamente é que me é indispensável estudar umas coisas que me são impossíveis de fazêr na Guiné, e agora é que me estão ocorrendo as ideas da Esthetica que convinha pôr a limpo. Não calculas bem o que é a gente pensar por si, arrancar cá de dentro ideas originaes. Novecentos e noventa e nove por mil das pessoas que fazem livros não escrevem mais do que a repetição em forma rarissimamente nova d'aquilo que já está dito. O peor é que é preciso verificar a exactidão das ideas geraes por meio de pequeninas investigações eruditas para que não tenho paciencia alguma. Nasci para cavalgar aventurosamente por cima dos factos, mas esse sistema já se não toléra hoje, época de accumulaçãozinha paciente. Has de vêr o livro do Vilhena. Depois de transcrevêr em trezentas e tantas paginas todos os poetas do mundo apresenta uma página de conclusão em que conclue... que um dos objectivos da literatura tem sido a expressão dos sentimentos humanos!!!! Aposto que já tinhas descoberto, sem estar seis annos a lêr os poetas a tiragem forçada!

Lembra-te de que se elles dizem difficil de digerir o «Anthero» 
apesar de o acharem bem escrito, muito mais difficil deverá ser concebê-lo. Francamente, eu bem quereria deixar a esthetica para mais tarde, mas as ideas veem-me, e que lhes heide eu fazêr? Andam-me a bailar essas e outras coisas na cabêça apesar de eu as querêr expulsar. Tenho pena de me não poder dedicar a sério do assumpto, porque na Guiné falta-me completamente o campo de acção, o espaço, o socêgo, as bibliotecas. Se tu soubesses como a estação è completamente incompativel com o trabalho intellectual! Cà também me não deixam. Se me fecho à chave no gabinete a Pilar e a minha Mãe ferem-se, de maneira que constantemente me veem falar e distrair. O Pessoa magôa-se todo se o não visitamos, e queixa-se à minha Mãe de que não sou amigo d'elle, «apesar de elle o não sêr menos meu do que o França», segundo elle diz. Em cada três dias, só um é totalmente meu, sem serviço. Sou um pateta, não é verdade? Que tens tu com tudo isso? Rebente, não trate de coisa nenhuma, corra os marinheiros, abandone os amigos, afaste com mais energia as matutices, deserte se fôr preciso, mas escreva testamentos á sua Luche. Não sei como tenho ainda a cabeça no seu logar. Os camaradas no dia seguinte ao serviço vão para casa e deitam-se. Ao menos descansam, e eu nem posso trabalhar nem descansar. Estou bem de saúde, muito alegre e bem disposto, mas tenho a cabeça dispersa por mil direç̧ões e fantasias. Não me repousa um instante. Tenho fome e como de duas em duas horas. O que é triste é que toda esta dispersa actividade é interior, não se vê, de maneira que ninguem a suspeita, e talvez ninguem acreditasse se eu a dissesse. Estou moralmente quietissimo, mas intellectualmente inquietissimo. Garanto-te que o teu irmão com oito dias d'este regime caia de cama. Tenho o sistema nervoso a trabalhar muito, se bem que alegremente e sem esforço algum, trabalhando o que os francêses dizem à vide. Olha o Mene: em seguida ao serviço dorme 13 horas a fio - e como aquella cabeça gira muito mais pacatamente do que a minha! Perdôa a porcaria desta carta. E domingo, tudo fechado, e pena, papel mata-borrão, é tudo uma desgraça.

Adeus, não sejas má com o teu noivosinho e não o trates como um vadio e flanante (do francês flâner!) porque és muito injusta. Olha que tem havido occasioes em que te escrevo muitíssimo, é justo que me consintas algumas épocas de menos assuiduidade [sic], mormente quando te vejo com a frequência destes ultimos dias. Supporta esta extravagancia por algum tempo, que ainda heide sêr tão regrado e estúpido como uma tartaruga. Nesse dia não te amará menos, nem mais, por impossível, quem agora te beija os pés.

A. $\mathbf{S}$.

Gostei immensamente da tua carta, minha Luisa, immensamente, immensamente. Não te escrevi porque ante-hontem á noite sahi com a Julianna, o Mene e o Eduardo, e porque esperava estar comtigo à tarde. Assim m'o disse a Pilar. Quando lá cheguei não me quiz demorar por causa dos homens dos candieiros e porque sendo dia dos teus annos calculei que poderia ir lá gente visitar-te, com a 
qual, como bem percebes, não me convinha encontrar-me. Não te falei mais á noite porque, $10^{\circ}$ não queria dar espectáculo e entreter-te dos teus devêres de dona de casa que recebe visitas, e $20^{\circ}$ queria cumprir a minha obrigação de dizêr duas coisas ao tio Alfredo, mulher, filhas, e principalmente á D. Maria Santos por sêr a tua primeira amiga. Se eu estivesse agarrado a ti em vêz de cada um de nós cumprir as suas obrigações sociaes desagradaria com toda a razão a teu Pae. Demais, sabes que não era fácil, para mim, por a conversa sêr difficil entre pessoas que se não conhecem nada, principalmente com pessoas pouco faladoras com estranhos e pouco desinvôltas como as tuas primas. Com a D. Maria Santos já a coisa foi mais fácil. Diplomacias a que não gosto de faltar, meu amor. Nem poderia falar-te á vontade num salão com tanta gente. A paixão não quadra nas salas mundanas, e eu mais do que todos devia sêr mundano e correcto. Competia-me fazêr o que fiz, põe-te tu no meu logar com um pouco d'esprit de finesse e verás que assim competia sêr.

Não sei se esta te chegará ainda a tempo, antes de partires para o passeio de automóvel. Fiquei pensando em ti, em ti e em ti, desde que de lá sahi até agora, com uma grande plenitude na tua lembrança. Tens o dom de me fazêr esquècêr tudo, e até a perspectiva da ausencia se desvanece no pensamento tranquillo de que te tenho. Quando o sol é forte e a terra exulta de primaverạ, não ha nuvens que durem mais do que o desfolhar d'uma corolla. Ás vezes, mas não muitas vêzes, vem-me o desânimo da partida, tanto mais pesado quanto o contraste é mais carregado. Paciencia, paciencia. Estou equilibrado, alto, e o teu amôr é para mim uma origem de força e de expressão. Que maior prova podes têr de que elle está na base da minha vida, e de que é são, e completamente abandonado a si mesmo, sem desfallecimentos e sem dúvidas?

A. S.

Quartel, 6 de Setembro (1909)

Escrevi-te hontem á noitinha e muito á pressa uma carta muito estúpida. Não ralhes commigo, meu amôr, não ralhes commigo. Fiquei tão desorientado por te vêr ralhar commigo! Bem sei que não devo mostrar apoquentação, porque é um exagêro e assim nunca me podes dizêr nada, e sêr franca, etc. Mas a verdade verdadinha é que ha 19 horas (são agora 6 da manhan) não tenho pensado noutra coisa. Estou com uma vontade louca de estar ao pé de ti, e recebêr de S. Ex.a absolvição plenária. Fiquei admirado de me vêr tão criminoso. Se falhei ás praxes, tenho a athenuante de que as não conhecia, e julgava pelo menos que tinha sido natural. Mas enfim, não me quero justificar mais, para não parecêr que discuto as tuas opiniões, quando somente as acato com remorso. Peço-te que me escrevas, não discutindo o assumpto, mas socegando-me a este respeito. Sou ao pé de ti e para comtigo como uma bolinha de sabão: a minha pequenina sopra, e logo me faz mal. Peço-te que não sejas muito severa neste assumpto de cartas, e que te convenças de que não são os momentos em que te escrevo aquelles em que penso mais em ti. Sabes perfeitamente que mesmo cuidando de outras coisas te tenho sempre ao fundo da minha consciencia, como a imagem não 
sáe do altar quando os fieis interrompem o culto. Teu marido respeitoso e ultra-amante.

A. S.

Minha ursazinha:

[Setembro]

10, oito da manhan.

Quando hontem à noite, por volta da uma hora, te ia a escrevêr, lembrei-me de que já não tinha estampilha alguma na carteira, porque gastára todas que tinha, em casa, com cartas de agradecimento de parabéns a pessoas de respeito e amizade. Fiquei muito desolado, e tive de desistir de te mandar cartinha para de manhan.

Não calcúlo a que hora te poderá chegar esta, e como vaes ao Lumiar, só a tens provavelmente á noite. De dia não pude hontem pensar nisto, porque tive muitissimo que fazer, além de um exercido de infantaria e de um artigo que o Botelho me deu para limar, o que me obrigou a escrevê-lo de novo por meu punho todo inteirinho.

10 e meia

Tive de interrompêr, e cá estou, depois de te falar pelo telefone. Visto não quereres que vá a anónima com esta, não irá. Levart'a-ei amanhan se me lembrar. Pois é verdade: fiquei todo cheio de fiapos do teu urso...

A Pilar foi hontem à noite a casa dos Chagas, e falei-lhe às 10 horas pelo telefone. Vejo que já folheias os Lusíadas. D'aqui a pouco poderás defendê-lo contra o grande admirador da Illiada, - a qual Illiada, aqui entre nós é de vêz em quando uma bem enfadonha, longuíssima, interminável lista de pancadas dadas e recebidas. «Então Fulano atirou a lança a Sicrano, que caiu do seu carro como um mergulhador; e depois esfoutro matou aquelle; e um tal ficou a deitar sangue pelo nariz; e outro caiu, e mordeu a terra; e A matou $\mathrm{B}$; e $\mathrm{C}$ furou o pescoço a $\mathrm{D}$; e $\mathrm{E}$ atirou abaixo $\mathrm{F}, \mathrm{G}, \mathrm{H}, \mathrm{I}, \mathrm{J}$; e $K$ insultou Lea seguir atirou-se sobre elle, e o trespassou, e a lança ficou no peito, etc., etc., etc....» Isto por páginas, páginas, páginas, páginas.... Mas que queres? No collegio ensinaram o homenzinho a admirar a Illiada, sublimada, decantada, esmiuçada, commentada, por milhões de críticos, grammáticos, eruditos, archeólogos, linguistas, filólogos, hellenistas, historiadores, humanistas, etc., etc. Todos lhe ensinaram a mitologia, a historia, a arte, a filosofia, o espírito grêgo. Ninguem the ensinou a vêr claro nas crenças, na historia, na civilizaçã̃o, no espirito, na alma, na religião e no trabalho brilhantíssimo do Portugal da Renascença. Lamentemo-lo a elle, e sobretudo lamentemo-nos a nós também.

Um grande, um fundo e luminoso abraço do sempre teu

A. S. 
[13 Setembro]

Segunda-feira, 10 e meia da manhan.

Acabo de te falar ao telefone. Pareces-me triste, minha pequenina muito amada, e com a preoccupação de que o estou também. Non è vero. Bastar-me-ia a consolar, se o estivesse, a lembrança de que me acompanhas sempre, e completamente, mettida dentro de mim, perfeitamente concorde com todos os meus sentimentos, muito identificada commigo mesmo.

Não pude hontem afinal lêr uma única página do livro de Sourian que me deste e que trouxera para cá. (La suggestion dans Vart); mas vi-lhe numa citaçãoo estes dois versos:

Ah! laisse que mon âme amène et boudissante

Déferle sur ton coeur.

Assim faria, se tivesse agora Vâme amène.

Teu e muito, sempre teu

A. S.

[14-9-09]

Correio geral (Terreiro do Paço) 8 e meia da manhan.

Minha ursazinha. Vim hoje cedinho com a Pilar para o Carmo. A minha Mãe chegou a casa ao amanhecer, tendo lá passado toda a noite. Contou-nos que a rapariga seguira toda a noite muito dolorosa. Depois de me demorar um bocado, sai, fui a pé pela Avenida acima, e retrocedi até ao Terreiro do Paço para te escrevêr. O medico diz que está tudo óptimamente disposto, mas que simplesmente hade sêr muito soffrido, em virtude da conformação orgânica interior. O resto o melhor possivel. Ella está, coitada, com uma cara contorcida e abaladissima; ha 17 horas...

Teu muito amante

A. S.

Quartel, 16 Setembro 909.

Minha Luisa: Estive no Carmo das 10 às 10 H da manhan, com esperanças de te encontrar lá ainda. Disse-me a Pilar que irias lá hoje, e lembrei-me de que o poderias fazêr por essa hora.

Como calculas, tive também muitissima pena de que o França me apparecêsse tão cêdo. Luisa, minha Luisa, que doçura de ti me 
vem, como és para mim como o sol para as rosas de S. Antonio, de que hontem me falaste! Sobre a Guiné, meu amor ouve: quanto menos tempo me demorar agora em Africa mais depressa tenho de voltar depois para lá. Já vês que os dois annos não seriam um grande mal, comparados com o pesadello de nos casarmos com a perspectiva de uma separação breve. Minha Luisa, como não pódes tu fazer idea da minha impaciência, meu amor, como me mandas perguntas como a da tua carta?

Estou convencido de que o Guyau não saberia quem ella era, porque então não falaria assim, ou, pelo menos, não conhecia de perto ainda a ella definitiva. Sei que casou, não me lembro com que idade, e que teve filho, um pelo menos, porque fala em um dos livros numas experiencias que com elle fez. Da morte, a minha frase, de que me não lembrava, parece-me mais nítida, ou por outra, acho mais natural e menos duvidosa a minha impressão. A proposito, sabes que me vem agora, pela primeira vêz, um horror fundo à morte, desde que sonhamos o nosso casamento, desde que ella me apparece como separando-me de ti? Não te podêr eu têr já, minha chammazinha vibrante, definitivamente apertada ao meu coração! Pequenina, pequenina, que fervorosamente eu te amo...

Ouve, gaivotazita: este espectáculo do soffrimento que agora tive, apesar de passageiro, apesar de absolutamente físico, apesar de sêr o germinar escuro de uma esperança, como a semence na terra é a esperança escura e dorosia [?] de uma flor, - este espectáculo da Julianna chamou-me outra vêz, como tantas outras, á piedade plenamente consciente, aos pensamentos de bondade, de perdão, de doçura, a um hino interior de pacificação e tolerância. São tendencias que sempre tenho, mas por momentos inconscientes, adormecidas, menos claramente patenteadas no pensamento. E toda esta expansão serena eu queria têr ao pé de ti, mas seria preciso que estivesse completamente entregue a mim, o que não é possível com misses, e gente a passar, e balbúrdias. São estados de espirito em que nos não mettemos por vontade, mas em que nos sentimos de vêz em quando mergulhar, sem o prevêr, sem dar por isso-Hontem mais do que nunca - mais do que nunca, minto: mas emfim, hontem muitíssima falta me fizeste, mesmo quando te tinha á minha beira. Não me fazem impressão as coisas exteriores? Não, não é isso que eu disse, ou que eu quiz dizer, se acaso bem reparei no que falava. Mas que explicações necessito dar-te, meu amor? Ai de mim se o não soubesses, se o não adivinhasses, se o não sentisses sem precisão de palavras minhas!

Ainda bem, minha Luisa, que te vaes entretendo com os livros e a arte. Ha arte e arte, livros e livros; a erudição sêca, a arte pequenina e pretenciosa são coisas vans. Mas que differença para as verdadeiras bellas ideas e para a grande obra de arte! Li outro dia um capitulo de um sábio desdenhando dos pintores, dizendo que desprezava todos os quadros, e só tinha admirações para os espectáculos naturaes, para as florestas, para o pôr do sol... Pois este sábio bem podia estar calado neste assumpto, porque se não lembrou de que o que ha de maior e admirável no espectáculo do pôr do sol ou no espectáculo da floresta são os sentimentos e as ideas que suscitam numa alma. Faliam da Naturêza: - mas uma idea é um fenómeno natural como qualquer outro, e o mais alto, o que exige uma mais espantosa combinação de fenómenos naturaes, e muito provavelmente o fenómeno natural por excellência. $O$ maior espanto não é o sol, nem a terra, nem os mares: é a espantosa marcha de uma céllula que em poucos mêzes se torna um organismo tão miraculoso 


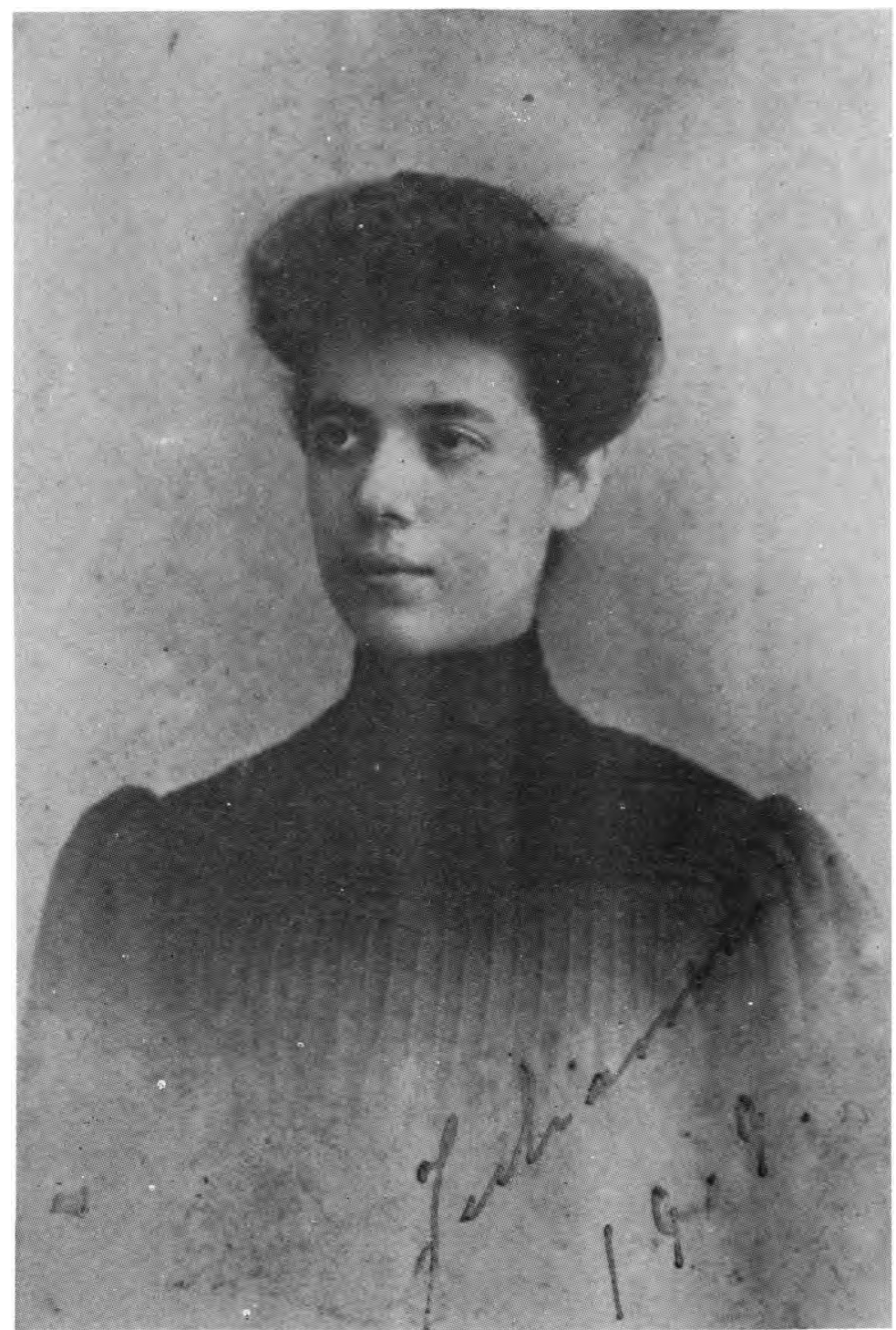

Juliana Sérgio de Sousa Pessoa, irmã de António Sérgio 
(Página deixada propositadamente em branco) 
em todas as suas minúcias como é uma criança, a qual poderá dar uma tão alta aetividade como aquella que produz as obras-primas do espirito. Na rosa se concentra e desabrocha toda a admirabilidade da roseira, e no cérebro humano toda a grandêza do universo. Quando ? idea admira o Cosmos admira-se a si mesma, que o resume, o prefaz e o concentra. Qual é a organização natural mais espantosa? - a do homem; nessa organização pode existir a verdadeira sublimidade d'este mundo: uma vontade amante e um pensamento generoso. - E aqui tens tu, meu amor, como o nascimento de um fedelho me fêz agora lembrar a opinião de um sábio sobre a arte... Adeus, ursazinha: não chames caturra ao teu maridinho, nem matuto. «O tipo é machucho mas é faiaco», dizia a filha da cosinheira, a pequenina de olhos todos pretos como uma azeitona. Sabes tu a historia? Pois o que ella poderia dizêr è que o tipo era matuto, mas havia ainda de gostar muito, e muito e muito da sua ursa.

A. S.

Minha pequerrucha:

Parece-me que me decido pela geografia e historia. Ha tantas circunstancias a attendêr? Em todo caso, naturalmente, requeiro para os dois grupos. Na quarta-feira não posso ir á noite a tua casa, porque tenho que falar a um homem que chega do Bussaco nesse dia, o qual só a noite me poderá dar umas informações de que carêço com urgência. É um tal Senhor Fernandes, secretário do Collegio Militar. Uma coisa: um Ramos, de que me falaste um dia como frequentador do Bensaüde, é official do Estado-Maior e chama-se Manoel Maria de Oliveira Ramos?

Teu

A. S.

Minha Luisa:

[19-9-09]

Chegámos agora mesmo ao Carmo, e logo a Pilar recebeu a tua carta. Mandou o portador embora antes de me falar. Recebi a tua de manhan. Paciencia, minha pequenina, está o teu Pae na sua razão e no seu direito. Levo-te a Pilar na segunda-feira, mas continua a parecêr-me imprudente o eu entrar. A ida nada tem, porque vou com ella. Mas quem me vir sair sozinho da tua casa áquella hora pode muito bem architectar uma calúmnia, escrever carta anónima a teu Pae, etc. Ficaria eu numa situação desairosa com elle e com teu Irmão, que tanta confiança me teem dado. Que se pensa a este respeito no pólo d'onde $\mathrm{V}$. Ex. ${ }^{\mathrm{a}}$ é uma das ursas mais distinctas? 
A calumnia é uma coisa terrível. A prima Leonildes disse-me que lhe tinham contado que a Valentina era de tal maneira doida por toilletes que o irmão se via grego para a vestir. Ora é, de sabêr que a pobre rapariga tem até um exagerado desprendimento por questões de fatiota. A cunhada é que lhe manda fazêr os vestidos contra vontade e com absoluta distracção d'ella a tal respeito.

$O$ homem effectivamente ameaça-nos. Sentia para com elle as melhores disposições de boa vontade e simoatia, e tenho pena se me obrigar a modifica-las. Por minha iniciativa nunca o ódio me entrará na alma. Compete-me a defensiva, visto ser eu o feliz e elle o desditoso. Segundo o meu costume, entrarei com os meios mais serenos e prudentes: só subirei de tom á medida que a isso imperiosamente me levarem. Não vejo inconveniente em que a D. Adelaide lhe fale, pelo contrário. Acho bem o que dizes, e por ahi se devia têr começado, em logar das frases bombásticas da carta que me mostraste hontem. Pede-lhe que lhe fale chanmente, frio e simples, fazendo-lhe vêr que a paixão passará por falta de alimento e de se podêr tornar em alguma coisa de mais estável e profundo que o tempo dá, etc. Enfim, como quem aconselha um exaltado ou um doente, com amizade, com tolerância, sobretudo com muita simplicidade e sensatêz. Com frases de Michelet não fazem senão malucar-se um ao outro, e não é possível intenderem-se. Ã D. Adelaide falta-lhe também a visão prática das coisas da vida. Não admira, calculo que não terá vivido, senão em imaginação. O rapaz precisa agora de um tratamento higiénico de sensatêz, e não de literatura e de adjectivos. A tal carta era uma embrulhada grammatical em 3 actos, quando se precisavam de coisas nítidas, pacatas e bondosas, - mas tudo isso simples, simplesmente feito e dito.

Calculas que uma Mãe falaria assim a um filho? Pois era esse o processo a adoptar, com uma certa cerimonia e cuidado, claro está, maneiras que a edade e qualidade da $D$. Adelaide impunham. Se o homem quer desabafar com ella, não vejo mal nisso, e era um bem que lhe fazia, mas devendo sêr um calmante e não um excitante, prática e não romântica. ¿ Mas como, se ella não sabe, se ella conhece a vida indirectamente, se não teve (provavelmente) a experiencia pessoal da acção, das paixões, das difficuldades reais da existência?

A Julianna continua bem, e o criancêlho modorra beatíficamente. Estou á espera de que chegue o Senhor Adolfo para te mandar esta. Acaba de entrar o Senhor Bagôrro, homem baixo, cheinho, bigode e cabello branco, cára còradinha de menino saudável. Uns 50 annos bem conservadinhos, farmacêutico, dedicado à família Pessoa de longa data. É de Arruda, terra de vinhos, e não sei que tal de bacêlos. Acaba de sair. Diz-me a Pilar que convém esperar que passe a tua hora do almoço para depois te mandar estes papeis...

Raparigas, tomae tento,

Rapazes, não vos fiéis:

Palavras leva-as o vento,

Cartas de amor são papeis...

Ouvi cantar isto no Algarve. As minhas, pequenina, não são só papeis. Não são: e estou certo de que não será preciso que t'o affiance o teu amantíssimo

A. S. 
Quarta-feira, 22 de Setembro (1909)

Minha pequenina muito amada:

Mando-te umas Rimas que farás o favor de entregar a teu irmão, um Anthero para emprestares ao barão de Merk [?] e para ti o Camões de 0 . Martins, que folhearás quando tiveres tempo. Não é preciso que o leias já, nem a seguir.

Manda-me a morada do Sylvio Romero (no fim da carta em teu podêr) para eu lhe enviar o Anthero; não precisando d'ella manda também a carta, para eu a mostrar ao Chagas.

Estava escrevendo a ultima linha da pagina anterior quando me chegou a tua datada de hontem à noite. Não posso ir na quinta-feira, porque me devo encontrar com o Raul Chagas ás $3 \mathrm{~h}$. afim de elle me informar o que se passou no conselho escolar do Collegio Militar, que reunirá nesse dia. Como vês, é um caso de força maior importantíssimo, que prima tudo, e de que talvêz possa dependêr o nosso futuro. Esquèci-me de te dizêr hontem que fui com o França ao Estoril no comboio da 1 h. $40 \mathrm{~m}$., conferenciar com o dito Raul, que lá está veraneando e que é professor de francês e inglês no Collegio. Combinámos então a entrevista de quinta-feira, na Avenida Ressano Garcia. Sexta é a despedida do França, e sabbado estou de serviço. Na mesma sexta vou lá a essa á noite, se não vês nisso inconveniente.

Beija-te as pontas das asas o teu

A. S.

Minha pequenina: escrevo-te da farmacia Cisneiros, de volta para casa. Entrei e pedi venia para escrevêr duas palavras, afim de aproveitar um marco postal que aqui ha ao pé. Encontrei o Mario Chagas que me disse ir para casa do Sr. M. J. da Silva, - e se eu queria alguma coisa para lá... Esteve todo o dia, como sempre, em pensamento comtigo o teu marido extremosíssimo.

A. $\mathbf{S}$.

\section{CARTA DE SYLVIO ROMERO A ANTÓNIO SÉRGIO}

Li o seu volume de poesias Rimas e venho dár-lhe a minha impressão infelizmente pouco desenvolvida. Sua poesia é larga e forte, como filha que é d'um pensamento disciplinado pela philosophia. 
Nada de lyrismo piegas e meramente subjecti vista existe alii e revive em todo o livro certo desencanto materialistico e pessimista, quebrado de vez em quando por grandes surtos de esperança e d'enthusiasmo. Para mim, porem a nota capital do seu poetar está na doçura, no enlevo, no quebranto, ia dizer - na meiguice, com que sente e falla das horas crepusculares, da invasão das sombras, no descer das noites sobre a terra, os mares, as matas, as cidades, os homens... Então su'alma se dilue, se mistura como em todo ambiente e despede notas verdadeiramente commovedoras, porque sentidas, como filhas do coração. Em Avé-Marias, Solidariedade, Brisa Marinha, Os Bois, Nocturno, Romanticismo, N'um Claustro, e até em Á Illusão estão ellas. A scena opposta de irradiação da luz - toca-o também, mas a intensidade é menor, ainda que notável. É o caso em O Pacifico, admiravel soneto cujo final é bellissimo; em Alvor, em Meio-Dia, em A Morte do Leão, valente inspiração só por si sufficiente para sagrar um poeta.

Dou-lhe d'aqui o abraço ou o beijo que merecem todos os grandes Talentos, eleitos da eterna poesia.

De seu admirador

muito amigo

Sylvio Roméro

Rio de Janeiro 6 de Setembro de 1909

Rua Sete de Setembro 113

106

23-9-09

Não valia a pena mandares tão especialmente e tão depressa a carta do Sylvio Romero, minha pequenina muito amada. Esperava hoje carta tua, esperava, mas pelo correio. Como saberás em breve, enganáste-te, porque te escrevi hontem á noite um cartãosinho. Tenho pensado em ti, e pensado, e repensado, portanto deveria estar pensando no momento de escreveres. Dir-te-ei pelo telefone esta noite o que resolvi depois da conferencia com o Raul Chagas: nessa mesma occasião te direi da partida do França. Será, provavelmente, de casa do Dr. Mario.

Este ultimo falou-me hontem á noite do teu irmão com elogio: que estava entrando por um bom e serio caminho, fazendo-se um homem a valêr, e que se conseguisse o que está intentando prestaria um grande serviço a teu Pae. Gostei muito da tua frase sobre estares «millionária»: oxalá sempre julgues que o meu amor vale effectivamente alguma coisa, e lhe dềs um preço que elle por si só merece no facto de sêr immensamente profundo, convicto, enthusiasta, resplendente e sério. Valho muito pouco, pequenina, e ainda menos em comparação do amor que te tenho: podes estar certa e certíssima de que mais bellamente se não pode amar.

No concurso de Salamanca ganhou o Monsaraz, como eu esperava por sêr amigo íntimo e obrigador dos membros do jury. Nem o meu soneto lhes chamaria a attenção, por não esperarem que elle contivesse o que contem: não é dos mais fáceis à interpretação $O R e$ fugio é todo marítimo e technico: é preciso sêr-se marinheiro e mi- 
litar (artilharia, etc.) para lhe dar com as subtilezas, que sem tal parecerão absurdas, ou mesmo na linguagem (gerba, prateados fios no cariz, etc.). Emfim, só perdi com isso 750 pesetas. Teu e muito teu

$$
\text { A. S. }
$$

Ainda bem que escreveste, meu amor, estava morrendo por palavras tuas. Todos os dias me parece que te amo mais, e todos os dias te amo como sempre. Está a tua imagem tão inseparável do meu pensamento como o sal da onda marinha, e o sussurro de uma fonte plácida. Ainda ha pouco te mandei uma carta (menos longa do que eu queria, para não fazêr esperar o homem) e já estou com uma vontade de rabiscar... Esta história do Collegio traz-me inquieto, e rebento se não desabafo comtigo - Se pudesse sêr, se pudesse sêr! A que horas irás a Carnide? Não posso estar sereno ou indifférente, por mais que queira. Ficava a nossa vida arrumada, por alguns annos pelo menos.

A. S.

Minha Luisinha:

[29-9-09]

Não te pode a Pilar escrevêr porque está dormitando por têr passado mal a noite. Appareceram a chamar-me ao telefone, quando estava falando comtigo. Mandar-te-ei o que souber hoje. Tenho pensado umas ideas que me surgiram hontem, e estou-as organizando antes que me escapem. Amanhan encontro-me com meu primo Silva Telles, professor do Curso Superior de Letras, e depois naturalmente começarei a folhear páginas de geografia.

Ama-te muito bem, muito bôamente o teu

\section{A. S.}

P. S. Não quero fazêr esperar o portador, que já da outra vêz julgou que nos esquècềramos d'elle. 
Minha pequenina:

Muito obrigado pela tua carta. Tanta pena tenho de não podêr agora 1er em ti todo o meu pensamento! Paciência, lembro-me que por ti ando agora mettido em toda esta confusão. Hontem, com o tal Senhor Fernandes pouco adiantei. Infelizmente não ha dissertação, única maneira de eu podêr mostrar superioridade. Paciencia. Sobre o assumpto da tua carta temos tempo de falar, não é verdade, meu amôr?

Hoje, indo a guardar algumas das tuas últimas cartas passei-as pelos olhos e só então me lembrei do teu pedido de versos cada mês. Como estamos hoje a 30, senti-me obrigado a fazêr alguma coisa para o mês que acaba. Ahi tens um soneto, feito entre duas páginas de um compendio de história:

Pedes versos, meu bem, o verso loiro

Como a espiga suspenso e baloiçado:

Meu estro és tu, meu coração, meu fado,

Minha luz vespertina e meu tesoiro.

Porque se cala pois a terra d'oiro,

Porque não solta a ave o seu trinado?

Mantem-me a vida preso em seu cuidado:

Ceu, paraiso, abismo e sorvedoiro.

Ou mudo ou solto em auras d'harmonia,

Tenha a doce expressão de quem confia

Porque a alma sorri, serena e pura:

Tanto monta o silencio e a voz singela

Quando repousa a lira, em si segura

Porque um divino amôr a guarda e véla.

Não prestam, mas não ha tempo para mais. Vou almoçar para ir têr com o meu primo Telles, que me escreveu a dizêr que já está em Lisboa e me espera na Sociedade de Geografia.

Teu

A. $\mathbf{S}$.

Minha Luisa:

Sabbado, 8 da s. d.

Impressionou-te a arenga da M.me Bensaude a proposito do Ferrer. Vejo que é a conversa geral e dominante. Como não leio jornaes e sei que se não deve julgar com aquelles juizos ligeiros de que 
fala o Eça numa carta de Fradique sobre o jornalismo, - abstenho-me de têr opinião, coisa que deveria fazêr muita gente boa. Abstine. $A$ explicação pelo jasuita (sic) é recurso constante e mirífico em pessoas «avançadas», «modernas», «intellectuaes», grandes espiritos profundamente nutridos depois de folhearem duas dúzias de folhas de papier noirci. Quanto á historia da Julietta, com seu balcão, seus cabellos louros e seu envenenamento no $5 .^{\circ}$ acto, será tratada verbal-

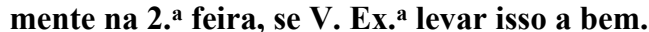

De Ferrers, revoluções sociaes, socialismos, anarchismos, etc., o que se deve concluir desde já de prático é que a vida frivola, de prazêr e de ostentação, da gente rica, deve passar. A época exige seriedade, dedicação, trabalho, simp..cidade de costumes, esforço de todos a favor do bem commum, para minorar quanto possivel $0^{\wedge}$ cataclismo que virá, - uma especie de invasão de barbaros interiores, de que Barcelona deu uma amostra pállida. Os millionários americanos sabem vêr as coisas, ao que julgo. Oxalá as vissem todas as criaturas de alguma illustração e de alguns recursos. Adeus, meu amor, fala-me amanhan pelo telefone às 11 da manhan se puderes. Leio distrahidamente compendios de historia, um pouco mais interessantes que os de geografia. A Pilar, que está aqui sobre o meu joelho, manda-te um beijo. Teu

\section{A. S.}

Minha Luisa:

Escreveste-me exactamente o que eu esperava e o que eu queria. Agora mais do que nunca preciso de uma palavra todos os dias. Falei hontem com o primo Telles. Disse-me que para quem nunca lêra uma palavra de geografia moderna, como eu, era preciso um trabalho formidável e um esforço de memória violentissimo, em virtude da pequenêz do tempo. O peor é ainda que no Collegio o estudo da geografia, segundo elle me disse (tem lá um filho) está desorganizado completamente, sem decidirem entre a orientação moderna e a orientação antiga, que me impingiram em menino. Decidi, claro está, orientar-me á moderna, mas corro o risco de me têr que havêr com coisa completamente differente. (Bastante differente é pela cérta). Emfim, é um jogo de azar. Ponho o futuro numa carta.

Adeus, meu amor vêr-nos-emos amanhan. Um descomunal e inexprimivel abraço cheio de saudades do immensamente teu

A. S.

O primo Telles começou por me aconselhar ir antes ao Francês e Português. Teimei. Diz elle que tem pena. Com mais algum tempo poderia ir plenamente seguro de me mostrar todo armado a moderna. Ficaria ou não, mas ficava a segurança da figura. Paciência. 


\section{Minha Luisa:}

São nove e meia da noite. Acabo de chegar da rua. Fui à livraria pagar o «Anthero» e encontro teu Pae. Recebeu-me com a cara mais amável e mais risonha que elle jamais teve em sua vida. Perguntou-me pelo Collegio, que seria realmente «muito bom» se se conseguisse, que desejava fazër a meu favor tudo que pudesse, etc. Porque é meu amigo bem sabe, hoje em dia, tenha-se o valôr que se tiver, os empenhos são tudo e por causa d'elles pode ser preterido. Achou muita pena em que elles naturalmente me guerreariam por sêr de marinha, e desabafou mais móravidades que na quinta-feira esmiuçarei.

Depois, quando soube que fóra liquidar a conta ralhou commigo: que não podia acceitar que eu fosse já fazêr aquella despèza, etc. O Senhôr vae fazêr-me o favôr de recebër outra vêz o seu dinheiro, e pagará mais tarde, quando a venda dos livros estiver mais adiantada. E restitui-m'o á saida, ás escondidas dos empregados. Como vês, uma boa vontade admiravel, de que deixo para viva voz alguns detalhes interessantes. Cá vou andando. Passei o dia lazarento porque a cerveja que me deste hontem me não deixou dormir, duas noites a fio já pesam. Peco-te que nunca mais me offerecas bebidas $L$ noite, chás, cafés, cervejas, e ainda mais que nunca insistas quando eu rejeitar. La -façon de donner faz-me esquècêr que ce qu'on donne é um verdadeiro veneno para mim áquella hora.

Adeus, minha pequenina muito amada, vou têr com a Pilar que ja se deitou e quer que me eu vá despedir d'ella. Manda-te dizêr de quinta-feira: tê-la-has a passar o dia. Adeus, adeus. Saudades ou recommendações ao João. Um grandíssimo e saudosíssimo abraço do teu irmão muito amigo, muito respeitoso e muito amante

\section{A. $\mathbf{S}$.}

Luisa minha:

[4-10-09]

Segunda-feira á noite.

Calcularás tu como as tuas bôas palavras me dão uma felicidade profunda, e quanto com ellas me sinto seguro? Quando todos me negassem tu havias de crêr em mim, e o que a inspiração, ou o talento, ou a bôa-vontade me podem dar de melhor é ainda a tua estima. Com ella me defendo, como a gente antiga nas calamidades alçava um crucifixo. Convence-te d'isso meu amor, e não te esquèças de m'as repetir. Vês? Treme-me o peito ao dizêr «meu amor", - exactamente como no primeiro dia. Estou-te escrevendo, minha Luisa, no mesmo sítio em que te falei tão turvado e tão vencido dos proprios sentimentos, e tão assaltado pela idéa das contrariedades que via ao nosso casamento. Gostaria de te têr commigo ago- 
ra_tanto!__ainda que tivesse de soffrêr as mesmas aprehensões e as mesmas dúvidas.

Amanhan terça-feira vou lá á noite com a Pilar. Se houver nisso inconveniente manda dizêr pelo telefone.

Ainda bem que teu Pae já gosta da idea do Collegio. Como tenho pouca esperança de ficar, receio que elle me passe a medir o valor pelo insucesso. Os seis mêzes é que talvêz não possam sêr emquanto eu não arranjar algum accrescimo aos magros 75. Hontem tive cá todo o dia oHenrique Vilhena, que me disse sêr esse o seu ordenado, e que lhe dava para vivêr com a mulher e duas filhas. Mas, mas... Mas digo eu, que não elle. Emfim, o mínimo seriam oito mêzes, para esperar pelo começo das ferias grandes.

Adeus, por 24 horas menos três quartos. São agora 8 e 15. Dá saudades minhas ao mano João, e lembra-te de que tens um marido que te amacom um amôr tão profundo como é profunda esta noite, e tão claro como ella è escura.

A. $\mathbf{S}$.

Luisa minha:

[5-10-09]

Die Wirtschaftsformen der Erde, Dia Haustiere un ihre Beziehungen zur Wirtschfat des Menschen: manda-me a traducção d'estes dois titulos com que a não sei que pedante germanêsco aprouve baptizar seus alfarrábios. Malditos allemães! Porque não ^falarão elles português?... Porque não piam em bôa lingua de Camões que s'intenda?

«Mas, pois que estar ausente lhe é forçado,

Por Senhora de cá vos reconhece

Aos pés de imagens vossas inclinado.

E pois vêdes a fé que nos offerece,

Ponde os olhos de lá no meu cuidado,

Dar-lhe-eis inda mais do que merece».

Com que então, só $V$. Ex. ${ }^{a}$ é que se ralou com a coisa de sabbado? Parece-lhe isso? Em todo caso, confesso que me não faz uma impressão tão enorme quanto me faria o faltar uma noite em sua casa ou um dia em casa da tia Helena. Só nesses casos é que estou á vontade,- - o que não quer dizêr que os outros me não saibam m. ${ }^{\text {t0 }}{ }^{\text {bem..., }}$

Gostei muito de que soubesses assim apreciar os cisnes. É preciso sabêr voltar a alma para tudo. Aviso $V$. Ex. ${ }^{a}$ a que não escreva «fazer o kilo». Kilo é peso, mil grammas. O ultimo producto da digestão, chama-se e escreve-se chylo. Se quizer, explicar-lhe-ei verbalmente o que isso é, mas como não tenciona sêr medica ou fisiologista não me parece indispensável. Entretanto não recolha o seu espirito, Senhora Joaquina: não recolha o seu espirito! Pense no seu hóme!

Está um dia maravilhoso, são 10 horas da manhan, depois do almoço saio e vou ao quartel entregar o requerimento. Desisto das distincçoes: não tenho quem vá á Luz. Acordei hoje ás 3, e tentei 
em vão readormecêr até ás seis, hera a que me levantei. É verdade que me deitei antes de darem as 10. Estou maravilhosamente disposto, e com uma gana de vêr cá uma bicha.

$$
\text { A. } \mathbf{S} \text {. }
$$

\section{5}

[6-10-09]

Luisa minha:

No domingo, se puderes fala-me das 11 da manhan em diante para o quartel, que ha pouca gente nas secretarias por sêr feriado. Caiu a noite, vou jantar e estou um nadinha desanimado. Porquê? Não sei bem, meu amor, vem-me a idea de que não fico no Collegio.

Ora, deixemos isso. Passe V. Ex. ${ }^{a}$ muito bem, e lembre-se de que cá está um pateta a pensar muito em si.

Um grande beijo, minha. Luisa, um grandissimo beijo nas tuas mão do teu

A. S.

Meu cysnezinho:

Quinta feira, noite.

Vim do Quartel ás quatro, e passei pela baixa à hora do movimento, - que já começa a ter seus ares de inverno. Lembrei-me ce que se o passaria cá - e pareceu-me coisa boa de mais para se

alcançar Toda aquella gente me deu uma vontade louca e inquieta de vêr uma unica, uma unica ursa do Jardim Zoologico!

Minha Luisa, faço-te passar em fantasia como uma brancura evanescente pela noite calma. Lembra-te de mim e escreve-me. Que farias àquella hora? Terminavas a lição da Madame. Terminavas a lição da Madame e falavas acaso em mim.

Teu

A.S.

117

Irmãzita minha:

[10-10-09]

Sabbado -

Ouço a noite, estou comfiado, penso em ti. Iremos na segunda-feira

Teu

A. S. 
Amôr meu:

[12-10-09]

É de manhan, estou no meu gabinete muito fresco a decorar fiadas de nomes geográficos: golfos, cabos, ilhas, montes, cidades, villas, aldeias do mundo inteiro, Os rosários mais aborrecidos de corrêr neste universo. $O$ que me vale é que dormi soberbamehte das 11 de hontem ás $4 V_{2}$ d'hoje, e em disposição magnifica me levantei. Aproveito o ir sair a Pilar para te mandar num cartão postal o mais bello abraço de que é capaz um homem que o sol só vê a pensar em ti, e a lua a sonhar comtigo.

A.S.

119

[13-10-09]

Quinta-feira, $1 \mathrm{H}$ da noite:

Queria-te eu dizêr, minha Luisa, que me agrada muito e muito o movei, o sentimento que te faz têr o trabalho de vir á noitinha, pela calada, abreviar-me estas horas fastidiosas de serviço, - mas que infelizmente o meio de que dispomos, o antipático telefone, com barulho, meninas bisbilhoteiras (de que ainda hoje me falaram) e a maçada que tu corres, me não deixam têr uma sombra do grandissimo gôsto que me dá, meu amôr, só o pensar na intenção. - Tive desde menino a fobia do telefone, mal calculando quanto elle me havia de entrar na vida, Não me intendo com elle; não me serve o não vêr com quem falo. Arranha me os nervos o bocal, que cheira a tabaco, e o auscultador com uma cegarrega de cigarra em dia estivo. Meu Deus! em vêz da tua voz, - rrrrrr, r, r, r, .... Algumas vêzes lá consigo conjecturar o que me dizes, mas na maioria resolvo-me a fingir que percêbo. Ora faz-me aflliç̧ão, minha Luisa, eșta idea de que te estou falando cheio de aborrecimento e de zanga. É estado de espírito que não quero ligar ao pensamento da tua pessoa. O progresso é uma grande coisa, - para o commercio, para a industria, para a fabricação das conservas, para a via não accelerada, - mas não para mim, minha Julieta, que não nasci para falar por fios. Suppõe que o Romeo, na scena do balcão, se lembrava de sêr surdo e replicava lá para cima: - O quê? Hein? Que dizes tu? Não oiço nada...

e que se resolvia afinal a dizêr que sim com a cabeça, a fingir que percebia. Nesta altura um espectador de bom gosto ia a casa, tirava um embrulho da gavêta, sentava-se no seu logar com a calma de um juiz e a imponencia de um patriarca... Ao subir o panno para o terceiro acto levantar-se-ia e antes que o heroe marcasse o veneno para c suicidio ali mesmo o estenderia a tiro de pistola, - em nome da esthetica e em nome do bom-senso. Ora não queiras que venha a sêr victima de um justiceiro assim o teu irmãosinho que tanto te ama

A. $\mathbf{S}$. 
[18-10-09]

Minha Luisa:

Com que então essa narigada ia sendo origem de uma catástrofe perfeita, com todos os matadores? Já chegou o mano João? Temo-lo na 2. ${ }^{\text {a }}$ feira?

São 7 horas, estive deixando correr o tempo depois do jantar, emquanto a Pilar tocava ao pianno e a prima Mia brincava commigo, com referencias a teu respeito, para réplica do que me metto eu com ella. Como era da bicha, fui ouvindo amenamente... Esteja-me alegre e pense no seu marido.

A. S.

121

Minha Luisa:

São 5 horas da manhan e escrevo-te doido de desespero. Não consegui dormir um minuto. O que mais me enfurece é passar assim uma noite inteira sem fazêr coisa alguma, sem paciencia para nada, com a certêza de passar amanhan um dia também incapaz de coisa alguma, 24 horas completamente perdidas depois de um dia de serviço, para na quinta-feira brincar aos soldados na parada e na sexta voltar a este inferno. E vêr que heide passar a vida assim, neste serviço de marinha todo feito de noite cortadas, que breve me hade escangalhar de vêz! Vaes julgar que é hoje uma excepção: não, meu amôr, é sempre assim no quartel, simplesmente hoje esgotei afinal a paciencia. $E$ tudo porquê? Porque tenho de andar de um lado para outro até ás $2 \mathrm{H}$, a patetar, num trabalho de giro que qualquêr galego cumpriria. Paciencia, paciencia! Mas a paciencia perde-se, e depois -

Não fales para cá hoje, espera que eu para lá fale, que talvez não sinta resignação sufficiente para aturar um telefone. Porque te admiraste de eu dizêr que não gostava que me contrariassem? Tens razão. Não era isso que eu queria: não gosto que me contrariem quando me não apresentam razões acceitáveis $e$ me atiram poeira aos olhos. E só tenho paciencia para discutir com certas pessoas. Com a M.me Bensaude não teria. Depois, eu não lhe poderia replicar á vontade, por via das conveniencias. É melhor, pois que não falemos no assumpto. O meu camarada que está de serviço tem dó de mim e de vêz em quando vem vêr-me ao quarto, desde que me viu apparecêr lá fóra com espanto seu. Levantei-me, vesti-me, puz-me a andar de um lado para outro. Pareço doido, e não sei se heide vir a sê-lo. 
Adeus, meu amor, não dês importancia a isto, porque me impedirias de desabafar. Espanta-me como o organismo me tem resistido a tudo isto e a muito e muito mais por que tenho passado. Decididamente, sou um bicho muito exquisito, e não o pareço tanto porque me não confesso. Valha-me isso ao menos. Não sou dos «montreurs». Ficaram-me estas extravagancias como resaca de tormentas várias. Quem as poderia explicar? Nem me eu já lembro de como ellas foram.

Promène qui voudra son coeur ensanglanté... Ensanguentado ou não, minha pomba, está a teus pés, e está bem.

A. S.

Minha Luisa:

s. d.

Começo a recebêr avisos de que o fidalgo visconde de Ottolini vae fortemente protegido pelo Paço e que me acautele. $O$ meu primo foi profeta. A Pilar saiu para a missa, e a minha Mãe disse-me que tu irias falar hoje não sei com quem para a Figueiró. Peço-te que, se o fizeres, seja dizendo que nos repugna immensamente a empenhóca, e de maneira alguma recorreríamos a ella: pretende-se unicamente que não protejam ninguem, nem a mim, nem aos outros, e tão somente equilibrar a influencia do outro, quanto possivel, de maneira que me garantam a neutralidade do jury. Neutralidade do jury e, sobretudo, neutralidade dos interrogadores. Isto e nada mais, mas peço que me garantam isto. Se teu Pae perguntar alguma coisa, explica-lhe bem isto, muito bem: pretende-se só a neutralidade.

Em minha opinião, o Senhor Ramos é o mais refinado dos hipócritas: amanhan te contarei da nossa conversa. Convinha-me que não fosses á M.me Bensaude antes de te indicar o que acabo de dizêr sobre o fidalgo e a naturêza das minhas pretensões. Tenho também umas coisas para vêr se dizes diante do Ramos, e ficarão para amanhan.

Teu

A. S.

Luisa minha:

s. d.

Farás saber à M.me Bensaude que depois do que ella fez me julgo na obrigação de cumprir as suas ordens. Dirás outrosim ao jantar ao Snr. Ramos as coisas necessarias para the insinuar doucement que eu de forma alguma seria idea ou vontade de me encontrar com elle numa occasiã̃o d'estas, para o maçar ou para lhe pedir qualquer coisa, de maneira que fique assente que vou sim, mas porque julgo que seria incorrecto não obedecêr à Madame depois do que ella fez. 
Morreu-me o Antonio Sergio, e fez-me o acontecimento grande abalo. Chorei como um burro durante algum tempo, e consolei-me um pouco fazendo-lhe um mau soneto que a Pilar copiou e que te mando. Que queres, allivia-me ás vêzes escrevêr qualquer coisa. Cheguei a casa á coisa de uma hora e deu-me a minha Mãe a noticia. Falaremos á noite. Teu e muito teu

A.S.

Vai pouco a pouco a rosa desfolhada

Caindo ao torvo pó que arrasta o vento;

Pelas aguas sem fim do esquecimento

Vae-se afundindo a pétala arrancada;

Vae-se apagando a face desmaiada,

Morre o lírio na dor do seu tormento,

E o sonho vão que erguera o pensamento

Mal o sol o tocou, se fez em nada.

Tudo o destino arranca, e murcha, e tira,

E até quem mal os olhos entreabrira

Logo no peito a morte lhe apparece:

Nessas mãos infantis que mal beijei

A surda escuridão comtigo desce

Todo um futuro d'oiro que sonhei.

[sem assinatura e data]

Minha Luisa:

s. d.

Disse-me a Pilar que querias os nomes dos homens do jury. Não pretendo nada do jury, meu amor: o unico cavalheiro que me fará partida, segundo julgo, será o Ramos. Só sobre o Ramos poderia haver vantagem em fazể pressão. De resto, dadas as relaçôes que sei agora por ti que existem entre elle o fidalgo, tudo se torna talvêz inútil. Só me poderá salvar um certo prestigio sobre os outros. Não creias que seja isto desânimo, porque não estou nada desanimado. Olho para o caso com bastante indifferença. Acho cómicas as contradiçôes em que o nosso homenzinho caiu. Diz ter pena que não fosse eu á mathematica, porque tenho no Ottolini um adversário catitinha. Por outro lado, faz-me o favor de me achar mais mérito. Mas nesse caso, não deveria temer, por mim, mas pelo outro. Vão lá adivinhar como trabalha uma cabeça de um Ramos. D'aquelle ramo não me póde vir bom fruto.

Teu, do coração

A. S. 
Minha Luisa:

s. d.

Espero que te não entristêça muito a chuva, e te não irrite a trovoada.

Dizendo-te que me sentia bem fisicamente não queria só dizêr que me não sentia mal: mas que uma boa disposição me levava para claras e frescas coisas, apesar de têr razões moraes para não estar muito bem disposto, nem muito confiante. Mas não insistamos, que a fatalidade é a fatalidade. O mundo é o Inevitável, - d'onde se segue que a indifferença é o papel do sabio. Ora ainda bem que podemos chegar ao menos á solução definitiva das coisas!!!

A Pilar está aqui ao pé de mim a dizer-te em escritura não sei que lérias. Boa saude, e melhor cara ao Destino.

Teu

A. S.

Minha Luisa:

â. d.

Escrevo-te da casa do Mene. Recebi aviso do Collegio militar exigindo-me que apresente carta do curso de marinha. $E$ um documento absolutamente inútil, porque na marinha não ha officiaes práticos; por outro lado apresentei uma certidão de todos os exames da Escola com os valores que tive, etc., certidão que diz muito mais do que a carta do curso. Esta custa muito caro, 30 ou 403000, e os sujeitos pensam assim levantar-me difficuldades. Pensando bem, é mais estúpido ainda do que mesquinho. Emfim, vamos aturando a humanidade e as suas virtudes.

Adeus, meu amôr, até amanhan. Quando voltam teu Pae e o João? Ficas só muito tempo ainda? Muitas e muitas saudades do teu noivo e teu irmão

A. S.

Minha Luisa:

[14 Novembro 1909]

Pelo que vejo, ainda d'esta vêz não houve coragem para dizêr o tal occulto pensamento de outro dia. Porquê? Não sejas assim, minha Luisa, não ha e não deve havêr razão para que escrupulizes em 
dizêr o que pensas. Maus pensamentos não os devemos têr; os bons não ha motivos para que os escondamos.

Sahi hoje ás 9 horas do quartel e deitei até á Estrella. Como cheguei cedo de mais entrei no jardim. Deu-me vontade de morar ao pé de um jardim. Vi os cysnes. Não sei se os mesmos que viste um dia. Um d'elles era defeituoso e tinha uma pata mal incerida que lhe saia, muito negra e muito feia, sobre a plumagem branquinha. Pobresinhos dos defeituosos!

«Let the swan

Float double, swan and shadow»...

Havia uma pequenina que se não queria arrancar de ao pé da grade e que os namorava. Empurraram-na para dentro: resistia, sorrindo, meio atraída e temerosa.

Let the swan

Float double, swan and shadow...

Vim para casa com as tias Mathilde e Carlota, Raymundo pae e filho, Julia, que se metteram no americano em que eu estava, á altura de S. Paulo. Saiam da missa e vinham visitar a Adelina pela morte do Pae. Agora entro de serviço de $3 \mathrm{em} 3$ dias: estarei pois na 4. ${ }^{\mathrm{a}}$ feira e não na $3 .^{\mathrm{a}}$.

Espero recebêr carta amanhan, elucidando o grão misterio. Virá? Teu

A. S.

$\mathrm{E}$ as duvidas sobre a intensidade, com que acabavas hontem? Porque teriam apparecido ellas, Deus meu, porque teriam apparecido! Lembra-te sempre de que tenho o espirito constantemente cheio de mil coisas, de que quasi tudo é fumo.

Minha Luisa:

16-11-09

Calculo que os teus receios venham de me sentires alheado nestes ultimos tempos. Repara que este concurso agora é o momento determinante e critico da nossa vida: do resultado dependerá uma differença radical no futuro. Ou uma existencia errante, e obscura, e estragada e triste pelas estações d'Africa, ou a fixação, a segurança, a despreoccupação relativa de «o que virá». Emquanto tivér esta espada da vida de marinha sobre mim, não me fica um segundo desanuveado. Tudo, desde o nosso casamento ás minhas occupações, está agora dependente d'este fiosinho. Quando se quer uma coisa A que depende de outra $B$, é preciso, e é natural, que nos fixemos nesta até que a obtenhamos. Não ha medo de que estes alheamentos se repitam, porque poucas vezes terei de me occupar ou antes preoccupar com coisa ao mesmo tempo tão incerta e tão importante.

Depois, este alheamento relativo tem-se dado em relação a ti um pouco (não indo lá a casa, escrevendo-te menos) mas não em relação á minha família, com quem estou em contacto directo, isto é, nas circunstancias em que heide estar depois para comtigo. 
Digo-te com toda a segurança que não tens razão alguma para receios. Contanto que te abras sempre, immediatamente, corrément, inteiramente commigo. Nunca deixes ficar lá dentro coisa alguma:

Le sévère dieu du silence

Est un des frères de la mort,

disse o Musset com muita razão. Sei-o muito bem por experiencia. Quando se vae para a frente das pessoas e se falia cruamente, desapparecem por encanto todas as dúvidas. A maneira de nos entendermos sempre é communicarmo-nos sempre. -

- «Tenho sempre o espirito cheio de mil coisas de que quasi tudo é fumo» - , quer dizêr: tenho-o sempre cheio de mil planos, de mil ideas, de mil luctas interiores a que não correspondem realidades palpaveis, utilidades vitaes, objectos que se vejam. São partes pois da minha vida em que só entrarás pouco a pouco, á medida que communicares intimamente commigo, em que trabalhares e pensares ao meu lado. Depois, quando estivermos juntos e occupados sempre nas mesmas coisas, os nossos espíritos coincidirão, e estaremos sempre, espontaneamente, um dentro do outro, pela força natural das coisas.

Dizes que te veem «medos», dúvidas da tua «força moral», receias «reacções». Coube-te a vêz de falar com palavras vagas. Creio que me calumnio: eu não fui vago, mas curto; tu, sendo prolixa, foste vaga. Ahi está um defeito a evitar. Peço-te que te exprimas sempre com toda a precisão, concretamente, chamando os factos pelos seus nomes particulares e próprios, sem a minima coisa que possa sêr um rodeio. Garanto-te que não ha motivos para te preoccupares. Confia nas minhas palavras, para teu bem immediato e para meu, que fujo de cuidados neste momento.

Teu marido muito amante

A. S.

Manhan de 17(?)-11-09

A tua carta deixou-me preoccupado desde hontem. Vaes promettêr-me solemnissimamente uma coisa: passarás a dizer-me immediatamente tudo. Esse processo de guardar, de ruminar, de fazêr misterio, um segundo que seja, é o que ha de peor. Se te tens confessado outro dia ficava tudo resolvido naquelle momento. Assim passei 4 dias aprehensivo e um preocupado. Com que vantagem? Para quê? Que motivo podia havêr para escondêres uma coisa tão simples? Nunca faças surgir preoccupações escusadas, que já bastam as que sc teem necessariamente.

Repito-te, minha Luisa, que podes estar descansada a esse respeito. Gosto de ti a serio - não sei se comprehendes o alcance da palavra, - sou o homem de melhor vontade para entrar no espirito de outrem, e creio não sêr obtuso de todo. Parece-me que são todas as condições necessárias para não estares receosa no assumpto que te trouxe aprehensiva. Tudo depende de ti: de te resolvêres a sêr transparente, aberta, heroicamente franca e communicativa. Quando duas pessoas querem $e$ se acostumam a dizêr tudo, hão de entenderle com certêza. 
Fica assente isto: nunca mais, nunca mais te calarás a uma pergunta minha, nunca mais conservarás fechado um pensamento. Já me viste fazêr o contrário?

De resto, esta combinação foi já feita e repetida. A minha pequenina tem faltado. Não a tomou tanto a sério como eu queria. Pois é preciso tomar a sério todas as combinações. A vida deve compôr-se de pensamentos sérios, nítidos, particularizados, bem concebidos e ordenados. Ora isto, que parece prosaico, é a unica coisa sólidamente poexica d'este mundo.

Muito teu

A.S.

Minha Luisa:

Não se ponha você a fantaziar contrariedades possíveis. $A$ experiencia tem-me dada isto: nunca a confissão plena fez mal, só o silencio desgosta. Desde o momento que nós nos esforcemos por pensar coisas razoáveis e boas não pode havêr inconveniente em explica-las. Você podia calcular que se eu lhe pedia addiamento, tinha para isso alguma razão que você approvaria logo que a conhecêsse. Mas quando lhe falei pelo telefone ás 11 horas da manhan estavam as secretarias abertas, e não me era portanto possível sêr mais explícito. Comprehendeu?.... Os encontros comsigo augmentam extraordinariamente a minha natural distracção no decorar a geografia. Aproveito o tempo 10 vêzes menos do que devia, e você faz-me perder 20 vêzes mais. Quando eu disse ao Botelho que estava noivo, lembrou-se elle pouco depois de me dizêr: «não é agora boa occasião para concursos: vem numa época péssima...»

Aqui tem o meu amor como as coisas são. Privo-me da sua companhia e no final heide ficar preterido. E a Fatalidade. Depois, os meus pontos de vista são provavelmente muito diversos dos d'elles: leio coisas que talvêz me não aproveitem nada. Estou a arranjar motivos de ralação?-não estou, pela simples razão de que me não ralo.

Seu irmão muito, muito amigo

A. S. 
Meu amor

[22-11-09] *

Correio geral 1/2 dia e 1/2 hora

Cá passei pelo Correio geral para lhe mandar um cartãozinho. Que fez hontem de noite? Eu estive triste, e fez-me afliçam não a vêr. Tinha vontade de me expandir comsigo, dizêr-lhe não sei bem o quê: os taes estados de espírito indefinidos, mas em que se é muito boa pessoa, muito puro, m. $^{\text {t0 }}$ calmo.

Teu

A. S.

Minha Luisa:

23-11-09

Quinta-feira, 1 da tarde.

Dá-me cuidado o receio de que o mau estado da linha com as ultimas chuvas faça transtorno ao ceu comboio. Gostaria de te ir esperar á estação, mas ao mesmo tempo as pressas da occasião, o mau humôr com que regressam os viajantes, o falar-te a furto para te vêr partir tendo-se apertado a mãoo sem quasi podêr dar por isso, - são pequeninas coisas, ridiculas, cuja repugnancia será incomprehensivel para toda a gente, mas que a mim me desagradam com uma pontinha de revolta interior. Comprehendes isto, margarita? Os ursos como eu são pouco adaptaveis a certas pequeninas cousas. De maneira que não sei ainda se vá, se não. Pouco geito para furtivo e para importuno. Não digas, meu amor, que sou um pateta inteirinho e completo. A desinvoltura muitas vezes não é mais que o resultado da falta de tacco, de impertinência, da indiscreção e da estupidez. Que diz V. Ex.. a a esta psicologia do importuno? Mandar-me-á dizêr se concorda com as suas observações pessoaes.

Amanhan passará por casa de V. Ex. ${ }^{a}$ o meu impedido para me trazêr as suas ordens: se quer que eu vá a sua casa, ou a $S$. Paulo. Se em S. Paulo já está a Maria, matavamos de uma cajadada dois coelhos. Mas em tua casa livrar-te-ás de têr de sair á noite, que talvez esteja chuvosa, e estarmos menos rodeados de respeitável público. Como quizeres.

Âté que emfim, minha pomba, vamos conhecêr a unica vantagem das separações. Até vêr. Um bom e grande aperto de mão do teu muito teu

\section{A. S.}


Minha Luisa:

7 da noite.

Escrevo-te da baixa, até onde deitei para ir á Sociedade de Geografia. Disseram á minha Mãe que te tinham visto hontem com o mano João na Avenida, a sair d'uma pastellaria. Ahi está um serviço de informações bem montado. Tem você pensado no seu irmãosinho? Encontrei um rapaz meu condiscipulo que é professor de equitação no C. Militar. Tendo elle dito lá, imprudentemente ${ }^{\wedge}$ que o tal Chagas Franco era republicano, houve um professor caridoso que espalhou sêr eu quem reeommendára o sermão. Veja você como o seu marido é patife! $E$ nem por isso deixa de a amar a você como só sabem amar os que são brancos como um lyrio

Teu A. S.

Minha Luisa:

Deu-me hontem á noite uma gran gana de te vêr e por isso te falei em ir a tua casa hoje. Espero para quando possa sêr, para evitar as duas horas de excesso em S. Paulo.

Contou-me a Pilar dos espantos do mano João a meu respeito. O mano João parece que não sabe o que é um homem precisar de prendêr a sua attenção numa coisa maçadora e têr ao mesmo tempo a imaginação a arrasta-lo para outras paragens. Já reparaste numa antinomia curiosa da minha pessoa? Sou criatura de acção geralmente (geralmente) plácida, e de imaginação irrequita. D'ahi a contradicção de um homem regrado por fóra, dando a apparência de fundamentalmente metódico, e por dentro alvorotado. D'ahi ainda a disparidade de opiniões a meu respeito: este chama-me fleugmático e aquelle um feixe de nervos. $O$ tal sujeito que me dizia empedernido pela matemática não sabe como, em vêz de um livro de equações, me sahi com um alfarrábio de versos...

Quando leio a geografia, meu amor, um quinto do meu espírito está realmente com a geografia, outro quinto com o futuro, dois quintos comtigo, e o resto commigo, com a fantasia, com os homens do collegio e com as coisas do Snr. Ramos. Lá dizia o outro que para o trabalho «non vale se non la solitudine dura».

Voltando ao mano João, gostei muito do interesse e môravidade que revelam as suas observações. Dá-lhe boas, e quentes, e convictas saudades minhas.

Teu

A. S. 
$O$ peor é que a maldita geografia me traz fechado, baixo, prosaico, sem horizonte, sem ar, sem espaço. Não sou agora verdadeiramente uma alma; sou uma cisterna. E ainda por cima não posso deixar nella reflectir-se como eu queria, como num lago, a tua imagem. Esperemos. Amen.

[26-11-09]

25, á noite.

Minha Luisa, consola-me a idea de que estou trabalhando para nós dois, para o nosso futuro, e para que elle seja mais brevemente nosso. Se as coisas inevitáveis, injustas, cegas, se não voltarem contra mim - contra nós - serão bem empregadas todas as contrariedades e inquietações e privações d'agora, - e mais, e mais que fossem. Encontrei hoje pela primeira vêz desde o collegio um condiscipulo que me disse sêr impossivel que me preferissem outro, mas que eu fazia mal em me rnetter no professorado: achava que o meu destino era sêr... «o Pierre Loti português»!! Não sabe o que é uma estação, e não sabe que existe a Luch.

Vamos suportando isto, minha Luisa, e lembra-te de que depois terás a melhor cousa que se pode ter neste mundo: alguém que viva comnosco, realmente e profundamente comnosco, em nós e para nós.

A. S.

Ah, meu amôr, se fosse antes um concurso de filosofia! Isto de decorar nomes, accumular factosinhos ao lado de factosinhos, sem tirar uma idea, sem tirar uma conclusão! Dá-me a impressão de uma criancinha que vae collocando pedrinhas ao pé de pedrinhas, sem fim nenhum, sem plano, sem razão, só pelo prazêr esteril de alinhar pedrinhas. Ha uma geografia interessante, ha, mas essa... será para depois, para eu a ensinar, - se m'a deixarem ensinar!

Dizes-me que estás desconsolada, minha Luisa. Porquê? Não sabes, ou sabes? Se sabes, dize-me - por extraordinario, por tudo que te pareça o motivo geral, por pequenino, por insignificante. Não ha nada extraordinario no mundo, nada do que incommoda é insignificante, - e os motivos que o poderão parecêr mais são ás vezes, para quem os sabe vêr por dentro, os mais naturaes e razoáveis. Se ha algum motivo, e se o sabes, tenho cá a conviç̧ão de que se m'o 
dissesses tudo se esvairia em fumo. Acredita, meu amor, que comprehendo as coisas, e que portanto nunca deves escrupulizar em m'as dizêr. Se eu te pudesse convencêr, se tu chegasses a vêr bem que assim é!

O Augusto, hontem, - eu disse-lhe que não tinha resposta, porque effeccivamente não havia a que respondêr immediatamente, mas sempre que quizeres alguma coisa, não só para mim, mas para qualquer serviço teu em que o homem te convier, deverás ordenar-lhe nesse sentido e aproveitar-te d'elle.

Mando o primeiro volume do «Bonheur de vivre», que a Pilar acaba de lêr e me disse que te queria emprestar.

Adeus. Estou lendo quaes são os paises que vendem o algodão o quaes os que compram as batatas. Calculo que te não interessará o assumpto.

Adeus, Luisa minha, até d'aqui a poucos dias, se o mano João vier em tua casa, e se não vier, em casa das tias. Depois de amanhan entro de serviço.

Teu

A.S.

138

27-11-09

Estou immensamente desanimado, minha Luisa: ninguem me despersuade de que, não dando elles os pontos, o concurso vae sér urna burla. Porque os não dão, se é sempre costume?

Para mathemática ha seis concorrentes: é o tal concurso para que não havia ninguem, no dizêr do senhor Ramos. Exactamente o mais concorrido. $O$ tal Ottolini, que o mesmissimo Sr. Ramos nos quiz impingir como terrivel, por toda parte me apresentam como não valendo um pataco. Quem mente deste feitio é capaz de se entendêr com um amigo, o que na realidade não é peor acção. $E$ aqui tens tu no que eu accordei a pensar esta manhan. Para que me serve neste caso estudar? Para quê? Para a burla sêr maior ainda?

Toda esta pequenêz me atabafa, sinto-me asfixiar. Se vejo isto acabado, se me torno a vêr no espaço livre!

Teu A. S.

Minha Luisa:

27-11-09

Tinha-te escrito esse cartão postal esta manhan. Mando-t'o para sêr fiel á nossa combinação. Não julgues por elle que estou abatido, ou coisa que o valha: enjoado com todas estas ninharias e comedias de pigmeus, nada mais, e uma grande vontade de me sentir final- 
mente eu. Sinto a impressão de têr caido numa teia de aranhiços. Ainda um mês de aranhiços!

Quando vem o João? Manda-me dizêr mal o saibas, para eu lá ir immediatamente. A M.me Bensaude gostou já: optimo. Canta, lê e não te lembres das toupeiras.

Teu

A. S.

\section{Minha Luisa:}

Escrevo-te de casa da prima Adelina, às 8 horas e meia da noite. Como? Porquê? Explicação: como não encontrei estampilha na minha caixa, desci a pedir uma emprestada à prima Miá, a qual me chamou «descarado», desconfiando o uso que the eu ia dar... E como ella estava escrevendo a não sei quem, quiz-lhe provar que era mais «descarado» ainda do que ella julgava: roubei-lhe immediatamente esta folha, lancei mão da penna... e aqui me tem $V$. Ex. ${ }^{\mathrm{a}}$.

Tenho à roda de mim nem mais nem menos do que a prima Adelina, Miá, minha Mãe, Pilar, uma costureira e dois meninos! Excepto a bordo, creio que nunca escrevi cartas entre tanta gente.

Ențro amanhan de serviço: adoeceu provavelmente algum camarada. É a época das gripes.

Já sabes quando partes? Deus queira que seja já, emquanto eu me não possa dedicar a ti completamente, - porque depois, acabada esta preoccupação e incerteza, quero-me desforrar. Ouviu você, ouviu? Tenho visto hoje de vêz em quando um perfilzinho encostado ao meu peito...

Adeus, pequenina minha, até amanhan, ao telefone.

Teu

\section{A. S.}

P. S. Saudades da prima Miá. Manda a Pilar dizêr que não póde lá ir amanhan porque está fazendo um vestido.

Cordeirinha: acabei de jantar, e aqui venho, porque... porque, não sei como, me da la gana. Coisas inexplicáveis cujas razoes subtis jazem no fundo de abismos fundos. Saberá vossa mercê porque se pescam peixes á candeia? Porque os peixes de agua salgada concorrem todos para a luzerna; ha pensamentos de cabêças ôcas que fogem todos para uma chammazinha... 
Pois, ia-lhe eu dizendo a vossa mercê que acabava de jantar. Jantar tristonho, sozinho, numa sala verde, bellicamente ornada com trofeus. Por unica companhia Sua Majestade, - Sua Majestade, de grande uniforme, branquinho de gêsso. Um dia heide têr uma figurinha morena de terra cotta, mas que hade palrar como os meninos pequeninos, indefinidamente, raciocinando para aqui e para acolá, de fazer tonta uma alma christan. Sua Majestade, esse, coitado é mudo; nem uma palavra às suas tropas. Também, metteram-no entre vinte espadas ernçadas que nem as settas de S. Sebastião. Pobre «Young King»!

Ainda iá tens a Madamesinha? Diz que num leilão se lembrou «dos seus noivosmnos». Eu respondi-lne que era cedo ainaa para pensar nos trastes, o que a espantou. Islão sabe ella da historia do collegio?

Adeus, meu amor; já visitei os encarcerados e estou à espera do teleione. um aoraço muito forte do teu írmãozmho m. ${ }^{\text {to }}$ amigo

\section{A. S.}

Sim senhor, cem a minha menina muito boa idea: como me disseram que o rapaz ia não sei aonde e voltava, aqui me tem a responder. Vejo que o «Bonheur de vivre» lhe trouxe, um rejuvenescimento de boas tenções, bonitas, saudaveis e fórtes. É preciso afazer a alma a uma tal idea da vida, como uma coisa bella formada de pequeninas acções simples, vulgares, quotidianas, mas transfiguradas pelo sentimenco e pela significação ideal que se lhes dá. Dizia Goethe (pouco mais ou menos) que se não trata tanto de realizar um ideal que póde ser mais ou menos vago e chimerico, mas de idealizar a realidade positiva de todos os dias. Se não foi isto que o Goethe quiz dizer algures, digo-o eu agora, e a minha pequenina não lhe oara por isso menos vaiôr. A veraadeira vida e significação das coisas não está nas acçoes que se veem, mas no munao interior, na serie de sentimentos e de ideas que correspondem a essas acções na aima que as pratica. Peia intenção, peia bondade, peia eiavaçao moral, pela consciência, transuguram-se os actos vulgares de tooos os dias, - como uma nuvem escura e vulgar, em lhe dando o sol, se transforma em arco-iris. Cervantes escreveu um dos livros mais alegres, memores, mais luminosos, mais bondosos, simpáticos, indulgentes, quando se arrastava numa prisão escura e torpe. Era um corpo estragado, arrastando-se em poeira? Eena, para quem vê as coisas de fóra: mas para quem as ve por dentro era um espirito de diamante a correr num ceu. Ora aqui tem a minha Luch como deve encarar as coisas, por mais que se sinta afastada do que os outros lhe dizem sër a realidade, a vida, o positivo. E preciso ser-se excêntrico, e experimentar a realização em nós das loucuras bellas. $O$ methodo tem além de muitas outras vantagens a de mudar em nosso proveito o valor relativo de muitas coisas que pelo criterio vulgar nos pareceriam muito peores. Já isso não seria pouco. Havemos de lêr juntos o Epicteto e o Marco Aurélio. 


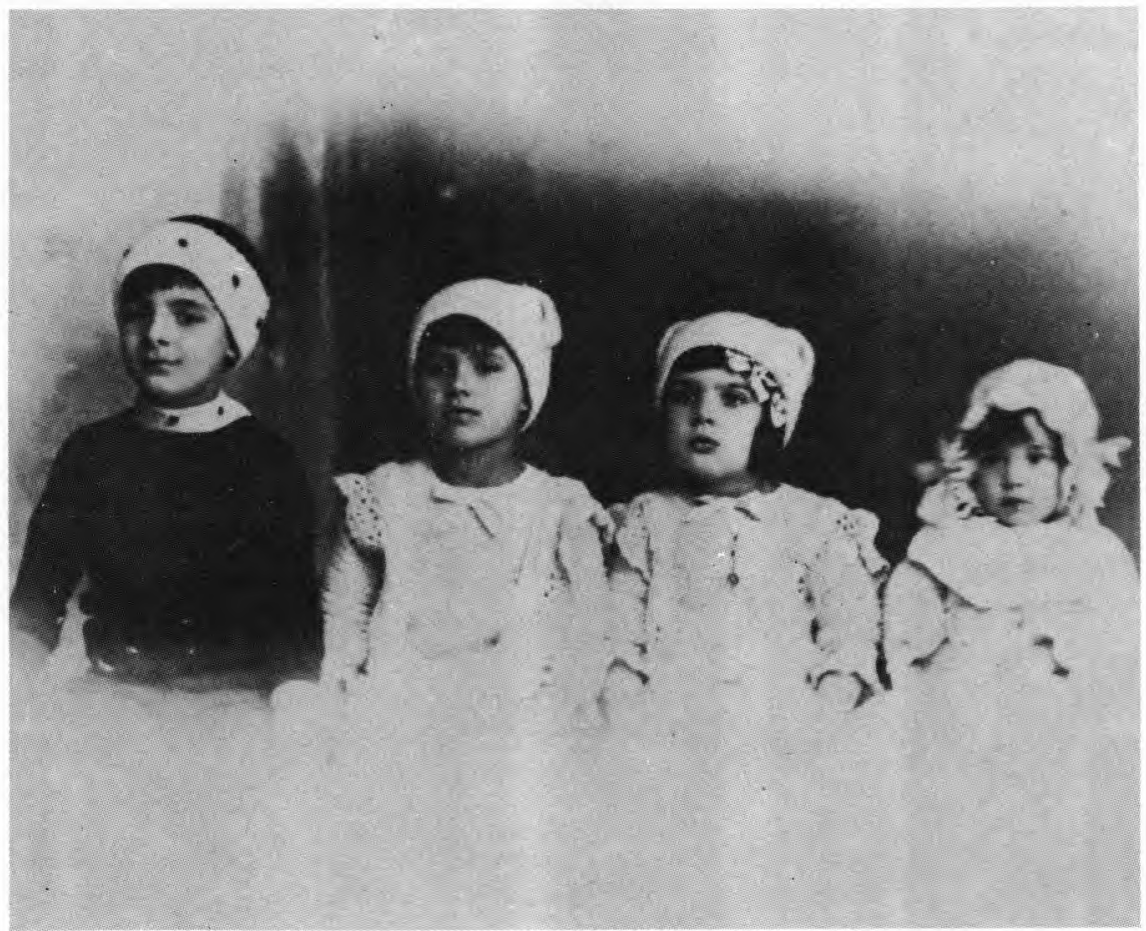

Sobrinhos de António Sérgio, filhos de Juliana: José (cujo nascimento é referido nas cartas), Maria Adelaide, Carlota Matilde e António 
(Página deixada propositadamente em branco) 


\section{Cartas da juventude de Antonio Sérgio}

«Ó Pan, e vós outras divindades que por aqui habitaes, dae-me a belleza interior!». Traduze christanmente esta ${ }^{\wedge}$ oração pagan de Platão, e recebe um grande beijo divino do teu irmãozinho

A. S.

Quarta-feira, 8 de Dezembro.

Recebi hontem no quartel uma carta tua, e hoje, ao chegar a casa, outra, que se recebeu cá hontem á noite. Gostei d'ellas, meu amor, como podes calcular, e adensaram-me as sombras como podes calcular também. Fecha os olhos, bate na terra, e segue, como eu tenho procurado, e como quasi me tenho habituado a fazêr desde que me entendo. Já que nada podemos fazêr por emquanto, atiremos o pensamento para todos os caminhos até que o futuro se resolva: talvez se resolva breve! Se se resolver, minha Luisa, acabaram-se os cuidados: é questão de tempo e tudo que dependêr de meios Jiumanos estará seguro. A esperança firme, bem ancorada e sem temores, é já a posse.

Cá vou indo. São quasi duas horas, só sahi do quartel depois do meio-dia, vou vêr se não perco hoje o dia como perdi hontem, e leio algo até às 5 horas, para ir depois à Avenida Ressano Garcia felicitar a D. Elisa e passar lá a noite. "A sociedade tem fórmulas», dizia um pateta que eu conheço. Suppõe tu um rapaz válido de 20 annos, acostumado a escalar montanhas, mettido dentro de uma doestas saias de verga com que se acostumam as crianças a andar, amparando-as. Assim estou eu. Obrigado como um estudantezinho à sua lição, veem-me à cabeça ideas, surprêzas, planos.

Belleza e atura se me vão em fumo!

Hontem não tive o telefone à hora do costume. Ahi está a queda de um habito a fazêr um vacuozinho. Si je croirais encore au bonheur, je le chercherais dans l'habitude. Muito se atormentou o Sr. de Chateaubriand, mas achou a formula, tarde, naturalmente, ou já impossivel, mas viu ao menos onde estava o segredo. Je le chercherais dans l'habitude. Nelle percebi eu ha muito o repouso da alma, que foi sempre para mim a imagem do bem neste mundo. E oxalá as circunstancias um dia nos permitam fundar sobre o habito o palacio da Gran Ventura! Ou estarei condemnado a deixar, como um judeu errante, a existencia pelo mundo em em [sic] pedaços repartida? Nem isso seria, mas sim desfeita, esfarrapada, apodrecida. Sumida em chavecos, obscuramente, ao pé de montes séceos. Separado de ti, - separado de tudo!

Hoje apeaste-te em S. Sebastiam, e foste à missa. Ha uma igreja interessante em S. Sebastiam, ao fundo de uma rua. Creio que ha. Estilo jesuita sem alma, mas parece que aprimorada, e não de todo brutta. Adeus, minha Luisa: interessa-te pela viagem, mostrate-te animada quanto puderes, e faze boa companhia ao teu Pae.

Teu e muito teu,

A. $\mathbf{S}$. 


\section{António Sérgio}

\section{4}

Lisboa, 12 de Dezembro, á noite.

Recebi hoje, minha Luisa, a tua carta de Londres. Numéro esta, para podêres verificar se alguma se perde: faze o mesmo as tuas. Que te direi? Estou como podes calcular: emquanto se não resolve esta historia ando fóra de mim, incerto, uma sombra por dentro. Veio cá a casa hontem o meu amigo Rego Botelho e troquei com elle o meu numero de embarque, por já estar em primeiro logar: temi que me mandassem sair ainda antes do concurso, e preciso de estar livre d'esse cuidado. Se não ficar no Collegio, tenho tempo para pensar no que farei, pois esta troca garante-me um anno mais.

São agora dez e meia da noite. Vieram cá jantar o Mene, Cavallarias, e respectivas mulheres, que sairam ha pouco. A minha Mãe e Pilar foram-se deitar: da casa de jantar te escrevo. Passei o dia a remexer papeis, procurando livros de documentos antigos que já não sabia onde paravam. Comecei a lêr algumas paginas de historia. É triste, a historia: uma mistura de cemiterio e de manicomio. A Origem e Estabelecimento da inquisição, do Herculano, faz dôres de cabeça. Em nome da religião, e do Christo, e da purêza da fé, revolvem-se os homens no lodaçal mais torpe, no mais hediondo descaro, numa hipocrisia de arripiar. Tudo se resume nisto: de um lado o pápa, do outro o rei. a roubar, roubar, roubar o desgraçado judeu. Érro: o rei roubava só o judeu; o pápa roubava o judeu e o rei; e a victima, depois de esvasiada a bolsa, era assada viva para gloria da nossa santa religião. Emquanto os homens forem as bestas-feras que são, as crenças, as opiniões, os interesses, não podem dar afinal senão bestialidade pura.

Minha Luisa, vê se te tornas cada vêz mais intimamente religiosa, mas cada vêz mais liberta das fórmulas, das exterioridades, dos ritos, da letra emfim. "A letra mata, o espirito vivifica», disse o Apostolo. Ora o espirito, minha Luisa, apparece-nos ao pé de quaesquer formas, porque no fundo as formas lhe são secundárias e indifferentes: os verdadeiros misticos são realmente sempre herejes, porque começam por estalar e ultrapassar as formas banaes, mesquinhas, consagradas e cristalizadas em que os cultos apparecem. É preciso sêr-se elevado, e puro, e angelical até onde se pudér, até ao absurdo: mas não se dê muita importancia às imagens pequenas, materiaes, infantis, de que não podem sair as imaginações inferiores. Tudo isto afinal é vão, porque resvala no teu espirito como uma seta enfraquecida numa couraça: só te convencerias com uma derrocada total, que eu nunca tentaria.

Adeus, meu amôr, por aqui me cérro. Não te desgostes das tuas jornadas. Lề o Mont des Oliviers, VEsprit pur, la Maison du berger. J'aime la majesté des souffrances humaines!

Teu

A. S. 
Minha Luisa:

Quartel do Carmo, 15 de Dezembro:

Escrevo-te de casa do Cavallarias, ao meio-dia. Vim almoçar com elle, saido do serviço do Quartel. Escrevi-te hontem uma muito longa carta, a lamentar-me e queixar-me de ti. Mas hoje, arrependido e concricto, não ousei pô-la no correio. A queixar-me de ti, minha pomba, vê que féra! $\mathbf{E}$ que fiquei exageradamente impressionado com que mais uma vêz viesses com dúvidas e suspeitas: aquelles receios de parecer piegas da tua carta de Paris, o reflectires se eu sentiria tanto como tu a ausencia, o notares o ajuisado das minhas cartas... Quando, minha Luisa, serás completamente espontanea, abandonada, quando confiarás plenamente? Faltaste à nossa combinação, pequenina, faltaste uma vêzz mais...

Mas deixemos isso tudo, não vá eu agora escrevêr-te uma carta tão tola e desanimada como a de hontem, que tive a boa inspiração de não pôr logo no correio.

Não sei bem se é verdade o que me disseram: que havia sud-express quotidiano, ou quasi. Escrevo-te hoje à toa, sem sabêr se hoje mesmo seguirá esta. A Pilar mandou-te ha dois ou três dias uma carta ao mesmo tempo do que eu. Como ainda não fui a casa, não sei se lá terei correspondencia tua. Se tu calculasses por ti o que me custa não te vêr, já não me sentiria constrangido agora: mas tu ainda te não habituaste a não têr comparações, reflexões, suspeitas, o não avaliar as coisas pelas palavras convencionaes! Quando te abandonarás tu plenamente ao teu natural, à emoção do momento, sem cuidados, sem medir, sem comparar?

Ai de mim, que lá volto ao assumpto! Minha pequenina, acredita em mim, que te amo muito e muito bem. Tem fé, não penses em como escrevo e em como escreves, manda para o inferno todas as duvidas e considerações. Está hoje um dia muito feio, com chuvasinha miúda, oxalá melhores tenhas tu ahi. Penso que sentirás talvez muito frio, e sinto-o eu com esse pensamento. Já me disseste que das outras vêzes o não tens sentido. Em logar de te repetir que tenho muitas saudades, minha Luisa, prefiro dizêr-te que sou sempre, e sempre, o teu

A. S.

15 de Dezembro, 3 h. da tarde. (-09)

Acabo de chegar a casa e de receber 2 cartas tuas (de 11 e 12). Fiquei alegríssimo. Ainda bem, meu amor, que já não pensas em desconfianças e dúvidas! Peço-te, minha Luisa, que não repares no pouco que te escrevo. Não tenho tido mãos a medir. Autos, o Cavallarias offendido por eu lá não ir a casa, visitas do Rego Botelho, troca de numero para estação, o Frederico que vem hoje cá jantar, não me teem deixado tempo para lêr uma pagina. Já perdi completamente 
3 dias a fio. Tinha tanta vontade de lêr a Historia do Chagas toda (8 volumes de 700 paginas de 2 columnas), aquella que o Frederico me offereceu nos annos, - tinha tanta vontade de lêr essas 12.000 columnas antes do concurso! Já perdi a esperança...

Não repares, meu amor: quando perco occasião de trabalhar ficam-me taes remorsos! Não é só o tempo em que escrevo: saio dos livros em que com tanto trabalho entro, começo a pensar em ti e depois custa tanto a voltar! Você, que nunca teve de se sujeitar a estas disciplinas e a estas torturas não sabe o que isto é. Você não sabe como estou impaciente, irrequieto, doido. Perdoa, minha Luisa, não me leves a mal tudo isto. Se calculasses a furia, a inquietação que me vae cá dentro! Vejo que não fazes idea alguma do que é a minha vida interior, quantas mil coisas por cá vão ao mesmo tempo! Não posso, positivamente não posso, Luisa. Não calculas como estou irrequieto. Se eu pudesse têr agora uns dias de placidêz e de socego! Impossivel, com a minha cabeça é impossivel. E tu a suppôr que me sobeja o tempo, a quietação para escrever longos testamentos! Adeus, meu amôr, faze por adivinhar a minha situação. Não me deixam. Hoje tenho a tarde tomada: veem cá jantar o Mene, o Frederico, não sei quem mais. Adeus. Três milhões de saudades do teu

A. S.

São 11 da noite, minha Luisa, acaba de sair o Frederico, que depois do jantar, posto que tencionasse seguir immediatamente para S. Carlos, foi ficando a conversar commigo até agora. Seguiu finalmente $^{\wedge}$ porque tem que acompanhar a casa a familia, que também lá está. O Mene, a Mathilde, a Pilar e o Roberto tinham saido para o mesmo teatro, a vêr a Reine qualquer coisa, opera francêsa, em recita popular. Vou-me recolher agora, porque tive quartel a noite passada. Deu-me a Pilar uma boa nova: disse-lhe a tia Helena que talvez tu viesses mais cêdo do que se esperava. Terá ella razões para o dizêr? ou foi atrás de vagas supposições? Se ella pôde sabêr isso era provável que eu pudesse sabêr também, por teu intermedio. Não creio portanto muito na notícia.

Gostei de que fosses ao recreatorio[?] em que me falas, para ao menos teres algumas horas não de todo inúteis e não de todo estúpidas, como essas que se gastam a recebêr e retribuir conveneionaes jantares. Acostuma-te a tomar um banho por dentro depois d'esses sacrificios à deusa "Sociedade» e ao deus "Mundo»: pensar 5 minutos numa coisa bella. E o Vigny? Abriste-o mais alguma vez? Já te entretiveste a admirar os bellos símbolos? $O$ lobo, - o estoico; a garrafa, - a intelligencia, a idea; o diamante,

Le DIAMANT! c'est l'art des choses idéales,

Et ses rayons d'argent, d'or, de pourpre et d'azur,

Ne cessent de lancer les deux lueurs égales

Des pensers les plus beaux, de l'amour le plus pur. 
Les pensers les plus beaux et l'amour le plus pur: eis, minha irmanzinha, urna bella divisa para urna existencia, - um bello programma para a nossa vida. Juremos ir sempre guiados pelo fulgor d'esse Diamante! Adeus. Um grande, um purissimo beijo do teu

A. $\mathbf{S}$.

Como tenho gostado das tuas cartas, meu amôr, como tenho gostado d'ellas! Chegam-me juntas, com grandes intervallos. Vieram-me agora duas de Londres, depois de 3 ou 4 dias sem nada. $O$ serviço dos comboios pelo que vejo não consente que a distribuição seja regular. Ao chegar a Paris deves encontrar em monte as que te tenho escrito. Podes crêr que tenho apreciado as tuas acima de tudo que te possa explicar. Tudo que me dizes indica-me um modo de recebêr, comprehendêr, acceitar e encarar as coisas perfeitamente conforme ao que me agrada mais, e mais desejo. Pode estar certa a minha mulherzinha que estou satisfeito com ella o maximo possivel. Nada me poderia, como calculas, dar agora mais prazêr.

A tempo veem estes bons signaes, porque tenho andado sem grande sorte estes ultimos dias. Occasiốes ha em que até as coisas parece que passivamente se revoltam contra nós. Para cumulo de aborrecimento cae-me em cima o auto de um preso que fugiu, e aqui tenho de andar de um lado para outro, e ouvir testemunhas, etc., quando mais me falece o tempo e a paciencia!

Com que então, não temos urso preto? Achei curioso falar-te eu no frio (carta do Carmo) e depois recebêr as tuas em casa, queixando-te do que irias apanhar em Londres. O bilhete postal para a minha Mãe chegou num dos dias em que nada recebi.

Estou de serviço nos dias 22 e 26 . O tal camarada que adoecêra já melhorou, de maneira que voltámos a 4 . E pois muito provável que esteja livre no dia da chegada. Escreves-me: «que bom quando te tornar a vêr!» Calculas que o mesmo sinto, com a mesma ou com maior intensidade, não é isto? Quando me poderei dedicar completamente à tua idea, com segurança, sem receios?! Se saiste de Londres na quinta, como dizes, já deves estar ha dois ou três dias em Paris. Very low? Porquê? Sê alegre, minha pomba: diz-te o teu marido que te ama muito e que está muitíssimo, e muitissimo contente comtigo.

A. S.

Tenho a impressão de que estás mais alegre e bem-disposta, o que também me alegra e bem-dispõe. Como a imaginação transforma o amador na cousa amada, o imaginar-te satisfeita é para mim 
a melhor origem de satisfação. O costume é quererem os noivos que suas noivas se mortifiquem quando estão ausentes: é amor isso? não, minha Luisa, é simplesmente aquelle egoismo que os homens sabem mascarar com nomes bellos; é ainda a desconfiança de muitos, que não fazem e não teem razões fortes para fazer das suas mulherzinhas aquella alta idea que tu sempre hasde querêr que eu de ti faça. Minha Luisa, radiquemos bem em nós esta idea de que não somos como quaesquer dois amantes, mas sim duas alminhas nascidas para se irmanarem numa muito grande e muito alta amizade, bem mais excelsa e mais diamantina que mesmo os melhores amores que nesta terra andam. Queiramos bem lucidamente $e$ bem fortemente que assim seja, e assim será, minha cordeira.

Que pensará e que impressão terá você da sua ida a Londres? Na City, nas pontes, na Trafalgar Square, em Piccadilly, no Museu Britânico, na Galleria Nacional, em Westminster, em S. Paulo, - lembre-se de que ahi já estive, muito só, numa época triste.

Nos dias que se seguiram á recepção da tua primeira carta de Paris andei arreliado com varias cousas que depois de [sic] poderei contar: concorreu isso para me apoquentar com certas expressões da tua carta. Perdoa as tolices do teu marido, meu amor: elle não é tão mau, nem tão absurdo, nem tão tolo como às vezes te poderá parecêr. Se tudo isto se resolve a nosso contento com que felicidade eu me poderei então dedicar completamente a ti, livre de inquietações urgentes, como eu me poderei agarrar desanuviado á tua dedicação! sê alegre.

Adeus, minha pomba muito amada. Pensa no teu marido, e

A. S.

Minha Luisa. Vou agora mesmo para o quartel, não porque entre de serviço, mas porque tenho lá que fazer. Decididamente, desde que saiste a má fortuna persegue-me. Recebi agora uma carta tua de Londres. Admiro-me de que nada meu te chegasse. No principio não mandei carta todos os dias porque não poderia desabafar senão coisas más: mil contrariedades, parte das quaes poderás adivinhar. Mas mesmo assim deverias têr recebido alguma coisa se não tivesse havido extravio, que com certêza houve. Tenho agora tido insomnias, e passo mal as noites do quartel, de maneira que a dôr de cabeça se vem juntar ao resto. Resigno-me, e vou aproveitando a lêr o tempo em que de todo não estou impossibilitado. Tenho tido pena de que não fosse bôa a tua viagem, mas as impressões e a sensatez que mostras diante das coisas e dos acontecimentos dão-me uma grande consolação. Crê sempre, meu amor, no muito serio e muito sólido affecto do teu marido

A. S. 
Quartel, 26 de Dezembro 09

Minha Luisa:

Mandei hoje o meu impedido perguntar a tua casa quando te esperavam, e responderam-lhe que talvez viesses hoje à uma da noite. Estou de serviço. Se puderes fala-me pelo telefone, porque até ás 3 fico acordado. Se não puderes hoje, toca amanhan á hora do costume. Se mesmo então não puderes, o que é natural porque as ultimas chuvas e ventanadas avariaram a rêde, manda uma carta à Julianna para que o Pessôa me communique a tua chegada pela rêde civil ou pela militar do quartel do Carmo, de maneira que eu o saiba antes de sair de cá ás onze horas. Isto no caso, claro está, de me não podêres mandar o teu rapazinho com carta tua tão cêdo, ou de me não podêres escrevêr ho je mesmo para me chegar pelo correio cá ao quartel ás 9 Va. Dirás também quando e onde nos encontraremos, em tua casa ou em S. Paulo. Tenho muito que ouvir, não é verdade, meu amor?

La vem a nau Cathrineta

Que tem muito que contar...

Ora, é de sabêr que estou ainda mais impaciente pela chegada da nau do que pela historia. Non è vero?

Teu

A.S.

\section{2}

s. d.

Pequenina:

Chegou agora mesmo o rapazinho, Ainda não abri o embrulho porque o não quero demorar. Três mil milhões de saudades do teu

A. $\mathbf{S}$.

Meu amôr:

Chegou-me a tua carta como uma alvorada. Lá estaremos às 7 Va. Nunca me passou pela idea que corresses perigo (nunca?... minto, mas emfim, claramente me dizia a cabeça que eram tolices) - porém suppunha-te immensamente aborrecida, como eu estava. Caiu- 
-nos por cima toda a serie de contrariedades. Foram umas semanas bem más, pequenina, quando virá a redempção completa?

Até logo. Um grandíssimo abraço do teu marido extremosíssimo

A. S.

\section{4}

s. d.

Acordei, meu amor, muito bem disposto e reconfortado com a idea de que já cá te tenho. Oxalá sentisses o mesmo. Até logo.

Teu

A. S.

155

Minha Luisa:

Quartel, 29-12-09

Ao sair de casa escrevi-te um bilhetinho que deverás recebêr logo pelo correio.

Foi hoje montado um telefone na casa dos officiaes de serviço, para funccionar depois de fechadas as secretarias. Tem para mim a vantagem de sêr limpo; e o inconveniente de quasi sempre não estar só a conversar comtigo: estará presente, em geral, o camarada que passa commigo cá a noite. Lembro-te pois a combinação já feita: responderei Antonio Sergio se estiver só, ou mesmo Antonio; se estiver acompanhado direi Sergio de Sousa.

Estou muito bem disposto, minha margarita: a primeira vêz desde que saiste para o estrangeiro. Dar-se-á caso que seja você, finalmente, a panacêa universal? Aposto que nunca lhe chamaram coisa tão feia! Não sei se te diga que o tempo tem andado ennublado, como eu, - e que hoje se vestiu de diamantes para me acompanhar. Cantam commigo as coisas. Recordo-me vagamente de que te ouvi hontem esta frase: a joy -for ever. Resôa-me cá dentro. Perché? Não é verdade que o illimitado nos apparece sempre como equivalente do eterno?

Parece-me que une immense espérance a traversé la terre. Se não fosse o querêr propositadamente afogar-me em prosaísmo até ao dia do concurso escreveria hoje um hino ao sol:

Midi, roi des étés, épandu sur la plaine,

Tombe en nappes d'argent des hauteurs du ciel bleu!

Adeus, meu amôr, lê hoje duas estrofes bonitas. Bonitas e cheias de esperança. Medita qualquer pensamento santo e luminoso. Ama-me como Castor a Pollux, como um anjo a outro anjo. Um dia cantaremos juntos e alzeremo una statua alla lihertà -

Teu

A. S. 


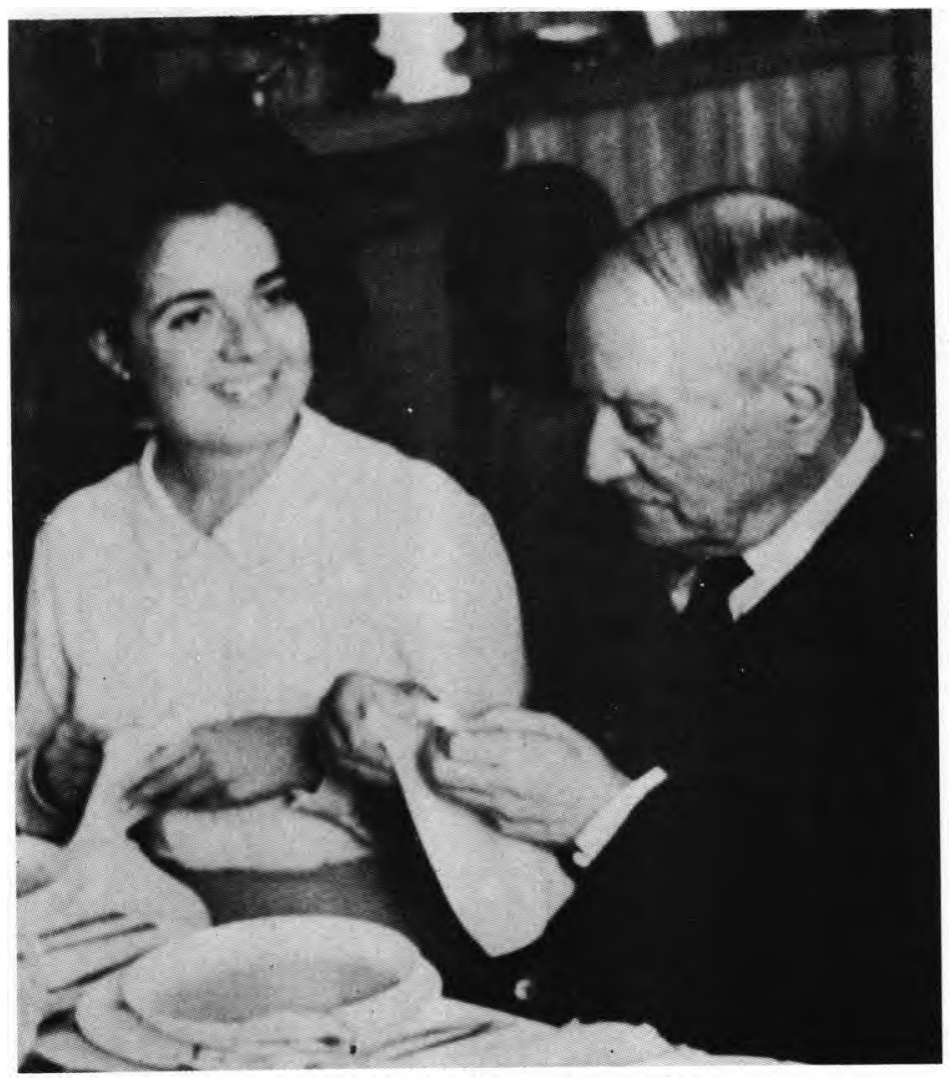

António Sérgio e a sua sobrinha-neta Matilde Pessoa de Figueiredo Sousa Franco (em 1967) 
(Página deixada propositadamente em branco) 
Minha Luisa:

31-12-09

A Pilar manda-te essas luvas que hontem lhe emprestaste, com todos os devidos agradecimentos.

Então? Commungadinha, em paz com Deus e a sua Igreja, em estado de Graça, já - desde que horas?

Não te fez mal - o jejum de hontem? Calculo que me não poderás talvez falar hoje pelo telefone. Em todo o caso não perco a esperança. Não te dês a qualquer incommodo de maior por isso. Jantas talvêz fóra, e de noite, pelo menos, deves ir com o Pae Silva e mano João a qualquer passatempo.

Adeus, minha Luisa, recebe muitas e muitas saudades, e acredita em muitos bons pensamentos do teu marido. Estou-te escrevendo no meio de officiaes que discutem, marinheiros que falam de serviço, etc. Não são propicias as circunstancias para uma longa carta tão longa como os bellos desejos que para ti formo, no alvorocêr d'este novo anno

A. S.

Minha Luisa:

Antes de tudo, é de justiça e de direito que comece por falar no encanto de bilhetinho do mano João. Apreciei-o o muito que merece e vale, e mais ainda, se é possivel. Far-lhe-ás saber isto, e também que não cumpro o meu devêr de lhe agradecêr já, porque estando tudo fechado e tendo-se-me acabado a minha provisão de papel aqui, tive de recorrêr ao Botelho, que só tinha estes bilhetes da Liga. Não me parece curial escrever-lhe nisto. E d'ahi, talvez vá.

Chegou-me a tua cartinha quando ia para jantar. O Botelho, que está de serviço commigo, combinou com a mulher jantarem cá juntos. Já chegaram, ella e duas filhinhas. Que dizes? Isto fez-me devanear coisas...

Adeus, meu amor - Comtigo estou, desde as 8 horas e tanto da noite de hontem. Ainda me não separei de ti, nem me separarei mais, por todos esses annos que nos hão de vir, risonhos ou não, cor de rosa ou cor de chumbo, mas que nunca poderão sêr muito maus, sempre que forem acompanhados de ti, do teu pensamento, e da certeza de que estás, neste mundo, para que eu sonhe em ti e para que tu me illumines o caminho. Uma grande, muito grande aspiração para ti do teu

A. S. 


\section{Minha Luisa:}

Escrevo-te deitado. Estava tão aborrecido que me vim deitar, a lêr na cama. E menos frio, e impede-me de andar, andar, andar pelos corredores, que é $o$ que não posso deixar de fazêr quando estou inquieto por dentro. Sinto-me calmo, porque já me desinteressei por completo da questão do Collegio. Vou ao concurso, para não ouvir e não desconsolar os outros: por mim, não iria. Podes calcular bem quanto é desesperadôr o que me succedeu. Engano-me: não podes calcular. $E$ ainda bem que não podes.

Parece que tinha o presentimento d'isto. Se acreditasse em agouros, tomaria por agouro este mal-estar e desesperança em que andei nos ultimos dias. Mas que importa? É um contratempo, uma tentativa que falhou, não pensemos mais nella e tratemos de aproveitar este anno que me deu a troca com o Kego Botelho para tentar outra coisa.

Adeus, meu amôr, está o teu rapaz á espera e não quero demora-lo muito. Chega-te depois tarde de mais a casa. Até amanhan. Amo-te muito, sinto por ti uma gratidão enorme, uma effusão de quem te devêsse tudo, o unico bem da terra. Rabisquei-te para ahi um soneto, quasi distrahidamente, a que por acaso falta um verso que me saiu defeituoso e que não tive paciencia de refazêr. Metti-o na gaveta do meu escritorio, porisso te não posso mandar (não esquècer que estou deitado, como já disse). Um soneto, para mim, é às vêzes o único calmante. Equivale ao brometo, ou à agua de rosas. É ridiculo, mas é assim. Adeus, pequenina, até amanhan. Mil lembranças do teu marido muito grato, como tu ás vêzes estarás para com a Virgem Maria,

\section{A.S.}

Chegou-me de manhan a tua cartinha, minha Luisa, que me fez bem. Estive effectivamente hontem muito aborrecido e bastante negro. Hoje sinto-me bem. Saí um bocado, depois de almoço, para apanhar sol. Passei pelo Carmo e fui vêr o meu sobrinho.

Decididamente, tenho andado com pouca sorte. Lembras-te de que me disseste, em casa da Mathilde, que o concurso versaria sobre historia patria? Ora, o concurso julguei eu que fosse a prova oral, aquella em que se fala, que é publica, para que se tira ponto. Ora, succede que me diz hoje o Pessoa têr-lhe communicado o Ottlini que a prova escrita seria de hist, patria, como eu naturalmente saberia. Ora, para isso não preparei eu as coisas: perdi pois todo o meu tempo e todo o meu feitio. Agora, à porta do concurso, venho a sabêr que tenho feito caminho errado. Deu-me ao principio uma furia, mas visto que a Fatalidade aposta em me contrariar nas mais pequenas 
coisas, curvo a cabeça e abandono tudo. Não digas nada a ninguem, faze cara alegre, e prepara-te para o golpe. Pensemos noutra coisa, e o vento que arraste tudo.

Teu

A. S.

Só um bamburrio, um acaso nos pode agora valêr. Virá?...

Não estejas com cuidado, pequenina minha; tu estás com certeza mais apoquentada do que eu, porque podes dedicar-te ao pensamento d'estas coisas desagradaveis. Não me succede o mesmo, porque estou tratando de remediar, o pouco que é possivel, os resultados d'este mal-entendido, ou, antes, d'esta pequenina esperteza do Sr. Ramos. Sua $\mathrm{Ex}^{\mathrm{a}}$ não se explicou bem, e ninguém me convence de que não houvesse intenção bem propositada da sua parte... Não ha que fazer as coisas por recadinhos, para isso é que se dão os pontos, mas isso não lhes convinha a Suas Ex... ${ }^{\text {s... }}$

Haja alegria à beira-mar, como se diz no Burro do Sr. Alcaide. $A$ mim, nesta opereta, compete-me 0 papel pouco agradavel, mas simpático, de burrinho. Para passar o tempo, entretem-te a analisar os factos e verás que requintes de falsidão, de esperteza, de jesuitismo há no fundo dos homens de óculos pretos que apregoam aos 4 ventos a sua rectidão... Deixa-los. Digo-te que estou sereno, indifférente aos casos. Podes crêr que é certo. A Sina cumprir-se-á, e como tudo é geométricamente determinado neste mundo, os patifes concorrem também para a Harmonia Universal. Cáspitè!

Não te apoquentes por mim, repito-te que estou perfeitíssimo. Vou lêr o que pudér. Tudo se perdeu, menos a honra. Elles perdem a honra, que é coisa inútil, mas ganham tudo e ficam-se a rir de mim. Boa idea, seu Soares!

Adeus. Fantasio que estarás de ursa, - pelluda e branquinha. Viva a ursa, e que durma socegadinha a sua noite.

\section{Teu}

A. $\mathbf{S}$.

Minha Luisa:

[s. d.]

Acabo de recebêr notícia de que foram annulados os concursos. Como vês, Deus-nosso-senhôr foi caridoso.

Dize-me se te convém que nos encontremos hçje, e onde. Teu

A. S. 
Minha pequenina:

Comment ca va? Acordei soberbamente disposto, e eis-me na baixa a vêr os linóleos que deveriam têr chegado hoje pela manhan da Alfandega para a loja. Não sei quê, Rua Augusta. Em breve estarás em S. Vicente; infelizmente Monsieur Phẻbus, Mr. Sun, Don Sol, entreocculta-se de quando em vêz. Occorreu-me agora o Bonheur de vivre para lêres. Queres? Traduze 2 ou 3 capítulos de que mais gostares, para desenferrujar a pena. Será depois apreciada a traducção por um comité composto de mim só. Valeu?

Minha Luisa:

A tua carta, vamos com Deus, não é muito animadora. Approvo as conversas "profundas", mas inquietam-me as conclusões desalentadas a que chegaste. Porque me falas no recurso a Deus «quando tudo nos abandona»? Em que falaram? Porque dizes de abandonos? Eu também não tenho passado muito alegre estes dois ultimos dias: esta surda inquietação em que me traz a indecisão prolongada tem de vez em quando os seus momentos agudos, mas não te quero vêr a ti desalentada. Não ha estado mais desagradável e abatido do que o de alguém que vê as suas coisas indecisas, e esse é actualmente o meu. Mas emfim, nada é de desespêro.. Por isso as tuas palavras me dessoaram agora. E ella, Pilar, tem agora pensamentos ennevoados? Porquê?

Adeus, meu amor: lembra-te de que tens um irmãosinho que vê para além das contigencias [sic] pequenas em que todos tanta tendencia teem a mergulhar-se, e que te é muito amigo, e muito grato, humilde amorosamente e meigo. Mais meigo e mais criança do que talvez suppões. Hontem à noite no teatro estive pensando nas vaidades humanas que são ingenuas, boas, simpáticas, e como a graciosa sombra que torna mais attrahente um quadro. E depois? Depois, ambicionei que sempre tu as visses com a mesma condescendencia e a mesma simpatia, - mas também com o mesmo desprendimento do que eu, - principalmente quando me fôr dado repousar nas tuas mãos a minha cabeça cansada, mas desannuveada de sombras vans.

Teu

A.S. 
Não, minha Luisa, não julguei coisa nenhuma por não falares ao telefone. Ouvi-te hontem mandar preparar o automovel para as dez: já vês que tinha elementos para avaliar a razão das coisas, ce taes razões fossem precisas.

Não se pode dizêr que seja em especial por culpa d'estes ou d'aquelles que se dão as tristes situações como a da pobre mulherzinha; o mal é da propria naturêza, da vida, do universo emfim. Ninguem mesmo é no fundo digno de expiação ou de castigo, por coisa alguma, porque não existe um fundo responsável no homem; nós pelo menos não o podemos concebêr. Porisso mesmo a toleranda e a abstenção são virtudes racionaes por excellencia. Se não a podemos concebêr como a maioria a julga, a liberdade existe ao menos como idea directriz, e isso basta para a vida pratica, e é o sufficiente para nos dirigir.

O que porém causa tristeza é que haja quem não sinta toda a profundidade do mal e quem leve a vida frivola e despreoccupada de tanta gente. Quem tem olhos para vêr e coração para sentir, como tu, tem obrigação de medir pelo seu valôr todas as ostentações, as manias de opulencia, de grandeza material; bemaventurados os pobres em espirito, os que teem a imaginação, não cheia de imagens de opulencia, mas trasbordante de verdadeiros pensamentos humanos. Pena ó que quasi ninguem perceba o que ha de subtil e de profundo na frase do Evangelho tão grosseiramente interpretada. Podem-se possuir milhões e sêr-se pobre de espirito; tenho fé que ambos nós o seriamos, ainda que herdássemos amanhan a fortuna do Rockfeller[?].

O estar-se mais ou menos livre de difficuldades materiaes é indispensável para que possamos effectuar no mundo aquella porção de acção espiritual de que somos capazes; mas os bens materiaes não nos devem entrar na alma. O mal vem todo, diz Camões nos Lusíadas, de se amarem as coisas que foram feitas «não para ser amadas, mas usadas». Bello e profundo verso, que é afinal precisamente o mesmo que a maxima de Jesus: «Bemaventurados os pobres de espirito!»

Já vês pois em que nos devemos afastar do ascetismo christão: a miseria é um ideal estreito, porque, se pode dar grandeza e liberdade ao individuo, priva-o de exercêr directamente uma fecunda acção na sociedade, e muito mais hoje em dia. A riquêza é um bem quando seja considerada como um meio e não um fim; e como um meio que nos dá liberdade para dedicarmos algum tempo ao bem social, quando é pequena; e, quando é grande, para a tornarmos a mola real de uma acção benefica directa. Os milionários americanos teem comprehendido óptimamente o seu papel. Consideram-se como peças indispensáveis para o melhoramento da sociedade, e tomam a sério o seu papel. Richesse oblige.

Minha Luisa, acostuma-te a olhar cada vêz mais para as realidades interiores. Estou e estarei sempre comtigo. e fortalecêr.

Pensa e lê alguma coisa alta e grande; sentir-te-ás confortar

Adeus, minha pequenina. Escrevo-te de casa do Mene. Este tem de ir para casa de um tio que está a morrêr, e eu vim com a Pilar fazêr companhia à Mathilde. Trouxe um livro para seroar - se pudér, porque accordei com a cabeça a doer-me como se estivesse dentro uma pedra. Se quizeres que nos encontremos amanhan, man- 
da-me dizer; se te não faz differença que seja antes quarta-feira, para mim era melhor. Não imaginas que pouca attenção estou dando ao que leio! De linha em linha surprenhendo-me (sic) a devanear em tão differentes coisas! Ha dois mezes para cá não consegui lêr talvêz 200 paginas! Quero vêr se ao menos amanham consigo alguma coisa, e para isso convinha-me têr todo o dia meu, sem esperanças que me distráiam. Ai, Luisa, como tudo isto me contraria! Estou como um doente que tem que tomar à força uma tisana repugnante. Amanhan, tisana; será quarta-feira a convalescença.

Teu

A. S.

P. S. Ainda me não chegou a traducção em verso da Imitação que mandei vir para ti. Heide vêr se pergunto porquê. Oxalá seja uma leitura bella e consoladora!

Minha Luisa:

s. d.

Vou para a baixa, e passando por casa da Mathilde: «queres alguma coisa para a Luche?» — me disse ella, — «vou lá mandar alguém». Em sendo $3 V z$ volto a casa a buscar a Pilar e deitamos até a Avenida Pinto Coelho. Está avisado o carpinteiro? O meu impedido está ainda no Quartel, de forma que nada fiz nesse sentido. Se não fosse a hora do lanche falava-te agora pelo telefone da baixa, mas não quero interrompêr inopportunamente.

Até logo

Teu

A. S.

166

s. d.

Minha Luisa: Estou no quartel do Carmo. Falei ao telefone, mas não estavas.

Não entro amanhan de serviço. Se tiveres occasião fala para cá (745), perguntando pelo tenente Pessoa.

Troquei o serviço para sexta-feira, a pedido de um camarada. Estamos aqui porque a Julianna caiu com grippe, de que vae já quasi arribada.

Que se fez hoje? Vejo que a amiga Perpetua ou retirou cedo, ou foi passear comtigo. Escrevi-te um cartão da baixa.

Teu, teuíssimo

A.S. 
Obrigado, meu amor. Já não me sentirei abandonado ao jantar. Como hoje um só, e terei para os outros dias sem ser preciso dares-te a maçada de repetir todos os 4 dias o foro. Avisaste a M.me Bensaude para se addiar o jantarico de terça-feira? Vê não te esqueças. Vaes também à despedida do João na 2.a? Ahi estão duas perguntas que tencionava fazêr-te hoje de manhan e que afinal escaparam. ${ }^{\wedge}$

Em sendo noitinha poderei falar-te pelo telefone, não é isso? Não repares que interrompo logo de principio a conversa, porque passarei para o apparelho de cima, onde estou mais à vontade. Não calculas, pequenina, como te estou grato pelo bem que me fazes, dando-me ao menos um ponto forte de apoio na continuação d'este longo noviciado doloroso que tem sido a minha juventude, e que não sei já se acabará, - e quando!

Teu

A. $\mathbf{S}$.

Minha pequenina:

18-2-10

Escrevo-te do botequim do teatro de D. Maria, até onde afinal vim dar, porque o Chagas está de serviço a bordo. E $02 .^{\circ}$ intervallo. Foi primeiro o Salto mortal comedia em redondilha, já antiga, do Lopes de Mendonça; depois, acabando agora a conferencia, que nada de novo me ensinou, como era de esperar de uma conferencia em teatro, coisa propria para espalhar conhecimentos elementares por um publico muito largo. Entretanto gostei de ouvir falar o homem, que sabe conservar-se sóbrio, elegante, fácil, construindo bem a frase e jamais descambando na rhetorica. Grande ovação. Enfim, uma grande vontade de te têr ao pé de mim, para palrar e commungar.

depois será.

Teu

A. S.

169

Correio geral, 4 h. da tarde.

Passando pela baixa de volta do Quartel, cá estou no meu devêr e doce costume. Sahi de Alcantara às 2 , e estive em $\mathrm{S}$. Paulo a sabêr da tia Pilar. Não está peor. E uma infecção (estomago) e reappare- 


\section{António Sérgio}

ceu-lhe a mancha do braço esquerdo que sempre volta em casos tais. Depois de amanhan entro de serviço. Fiquei pensando na visita de hontem.

Teu

A. S.

170

Minha Luisa

5-4-1910

Correio geral, 1 da tarde

Já fui hoje a casa. Como hontem de tudo que lá estava não era a mobilia que mais me interessava, só agora vi bem os teus móveis, de que gostei muitíssimo. Teem toda a graciosidade do Luís XV sem certa sobrecarga, nem o esvaido das cores, nem o dourado de algumas. Adiantei um pouco a arrumação dos livros. Era favor mandares encerar primeiro a estante, para eu lá ir pondo as edições mimosas dos poetas: Hugo, Prudhomme, Vigny, etc. Vou preparar o contracto do gaz, mas precisava de que me dissesses primeiro o que queres sobre fogão de gaz, etc.

Teu

A.S.

A agua fica prompta amanhan de manhan

171

Luisa minha:

6-4-10

Como vae isso? Chegou-se bem a casa, dormiu-se bem? Quando escreves ao mano João? Preciso de lhe responder ao bilhete da Tijúca, mas não sei como ou para onde.

M. ${ }^{\text {tas }}$ saudades do teu irmãozinho

A.S.

Minha Luisa:

Recebi o teu cartão. Já escrevi ao senhorio sobre o encerar da casa. Fui ao Soares: os moveis do escritório devem estar promptos dentro de uns três dias. Esperava que custassem mais os oleados. 
$A$ Pilar propõe-te irem amanhan as duas à Avenida Pinto Coelho; não sei bem para quê; cuido que para vêr a altura em que estão as coisas. Ou tu passas por lá, de caminho, ou o Mene a vae levar a tua casa, por volta da 1 hora.

Teu

A. $\mathbf{S}$.

173

Minha Luisa:

10-4-1910

Sabbado, 10 da noite

Ora, tenho a dizer-lhe:

1. Que o homem da tina de banho é primo do José Cisneiros, ? quem faz grandes abatimentos. $E$ pois melhor suspenderes o negocio, porque o José me faz o favor de a comprar.

2. ${ }^{\circ}$ Que fui à loja da loiça. Vi 4 aparelhos da Vista-Alegre que me agradaram mais que o tal de borda azul. São os de 36\$, 21\$, $27 \$$ e 29\$000 reis. Se lá passares, examina.

3. $Q$ Que decidas o caso da sala de jantar, e communiques á gente a decisão.

Parece-me que o Mene e a Mathilde foram lá à $R$. Antonio Maria Cardoso a vêr se me encontravam. Alugou a casa, por 450, segundo nos contam as primas Salter, em casa de quem te escrevo. $\mathbf{E}$ até segunda.

Teu

A. S. 